Szegedi Tudományegyetem

Gazdaságtudományi Kar

Közgazdaságtani Doktori Iskola

Szakálné Kanó Izabella

\title{
Gazdasági tevékenységek térbeli eloszlásának vizsgálata a magyar kistérségek példáján
}

Doktori értekezés

Témavezetők:

Prof. Dr. Lengyel Imre

Intézetvezető egyetemi tanár

SZTE Gazdaságtudományi Kar

Közgazdaságtani és

Gazdaságfejlesztési Intézet
Prof. Dr. Krámli András

Egyetemi tanár

SZTE Természettudományi és

Informatikai Kar

Bolyai Intézet

Szeged, 2012. 
Mottó: „Ha kifejezetten keres valamit, megkockáztatja, hogy kihagy valamit, amit nem keresett."

"'If you look for something in particular, you run the risk of missing something you weren't looking for."

Temperance Brennan, Bones 


\section{Tartalomjegyzék}

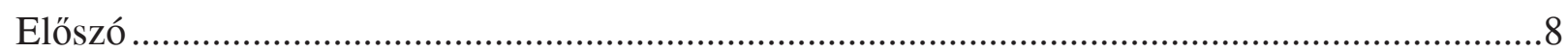

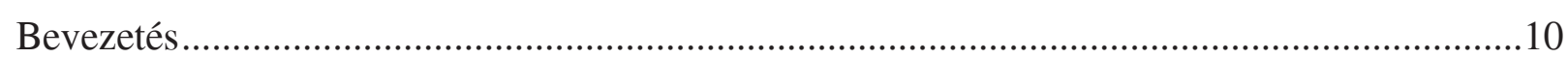

1. Térbeli eloszlás, koncentráció és agglomeráció ..............................................................13

1.1. A gazdaság térbeli differenciáltsága mögött húzódó folyamatok ...................................14

1.2. A gazdaság térbeli eloszlásához kapcsolódó fogalmak ...................................................20

1.2.1 A vizsgált gazdasági tevékenységek köre (BGM) ...........................................21

1.2.2 Független területi egységek vs. területi autokorreláció (LM) .............................22

1.2.3 A két megközelítés összevetése ….................................................................25

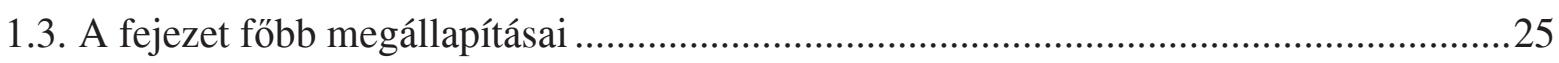

2. Az ágazatok térbeli koncentráltságának, illetve agglomeráltságának vizsgálati

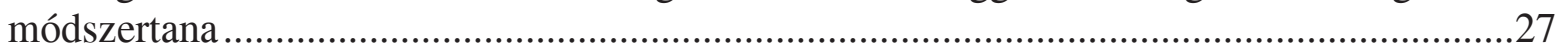

2.1. A térbeli koncentráció mérése ...................................................................................28

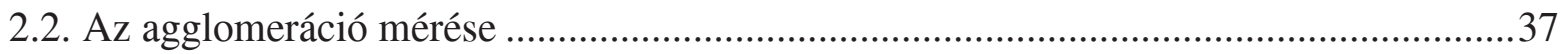

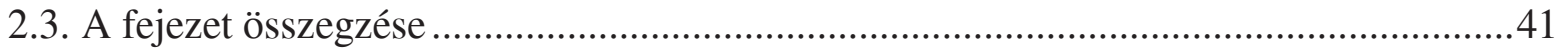

3. Az ágazatok térbeli koncentráltságának, illetve agglomeráltságának vizsgálatai:

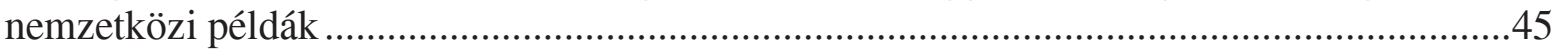

3.1. Ellison-Glaeser $\gamma$ alapú térbeli koncentráció-mérések .............................................47

3.1.1 USA 49

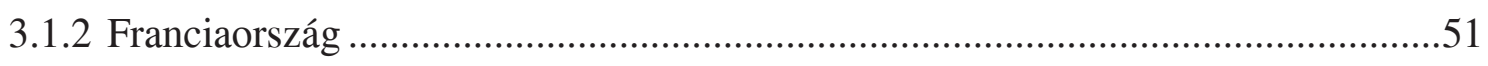

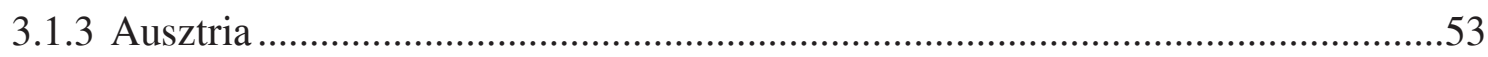

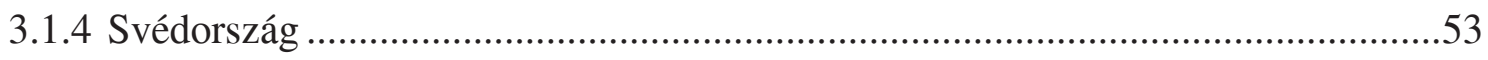

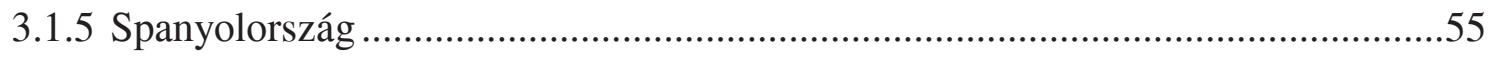

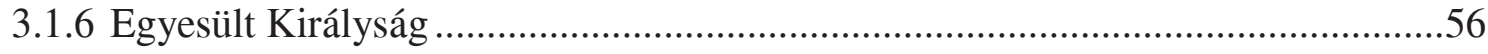

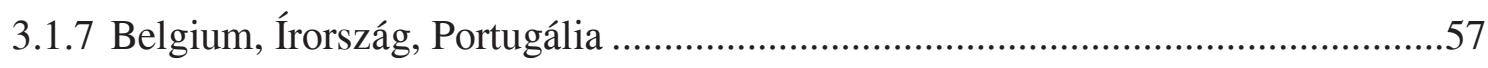

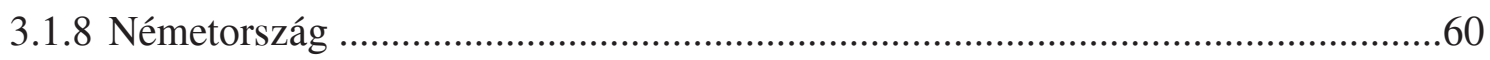

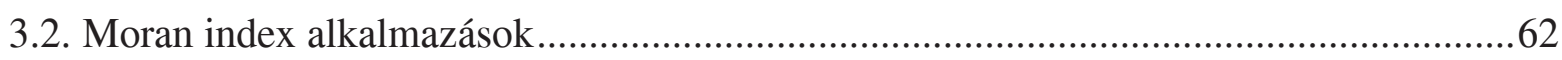

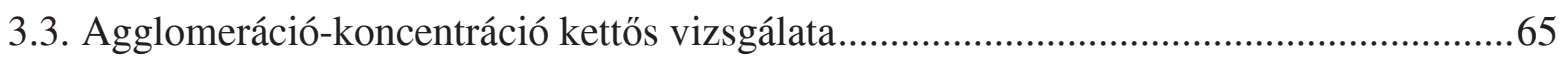

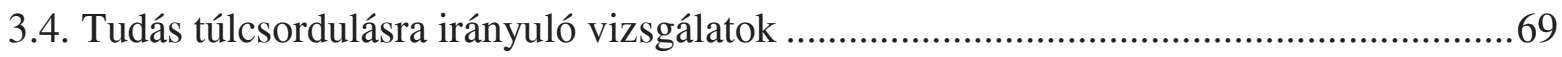

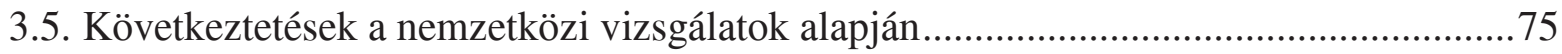

4. Az ágazatok térbeli koncentráltságának, illetve agglomeráltságának vizsgálata

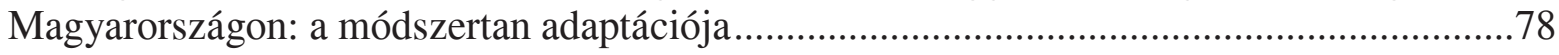

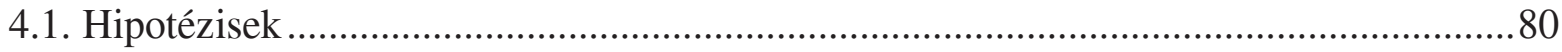

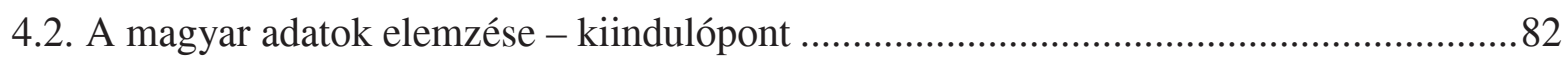

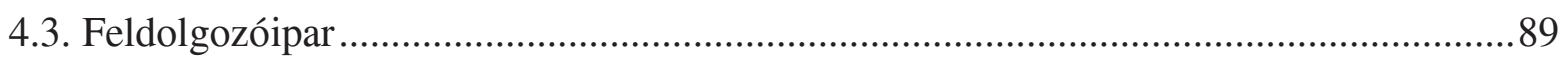

4.3.1 A felhasznált adatok és a kiszámított mutatóértékek ........................................90

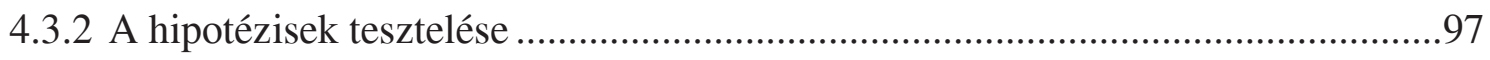




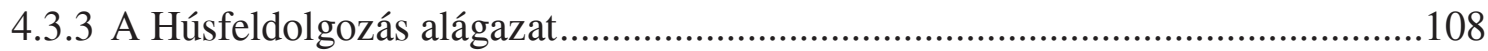

4.3.4 A Közúti gépjármü, gépjármümotor alkatrészeinek gyártása alágazat................110

4.3.5 A feldolgozóipari alágazatok térbeli eloszlása - összegzés................................113

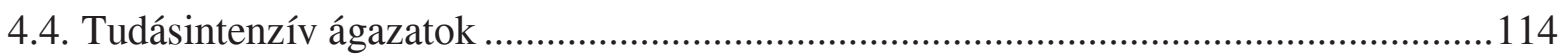

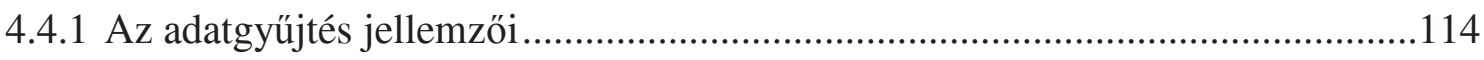

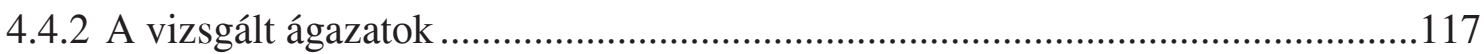

4.4.3 Tudásintenzív feldolgozóipari ágazatok térbeli eloszlása..................................119

4.4.4 Vegyi anyag, termék gyártása ........................................................................ 121

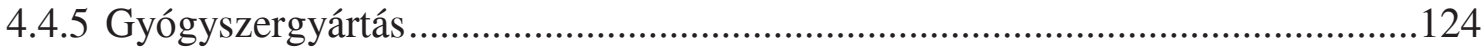

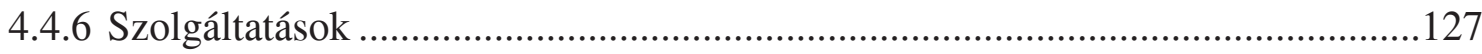

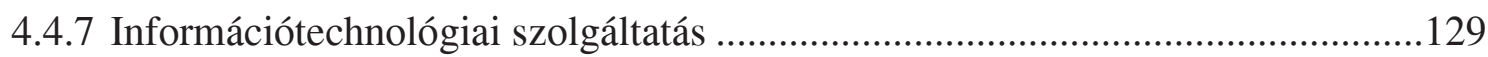

4.4.8 Pénzügyi közvetítés, kivéve biztosítási, nyugdíjpénztári tevékenység................133

4.4.9 A tudásintenzív ágazatok térbeli eloszlása - összegzés ......................................136

4.5. Módszertani eredmények és megjegyzések..............................................................137

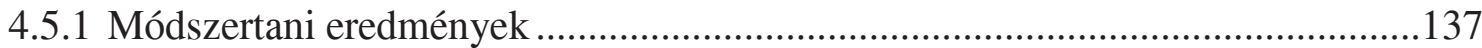

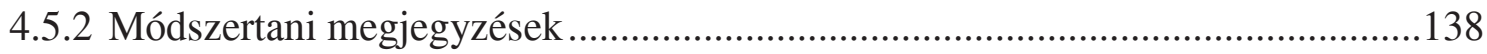

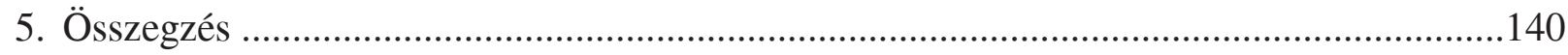

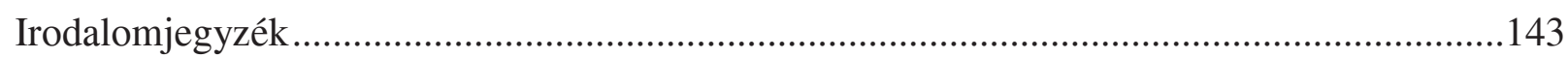

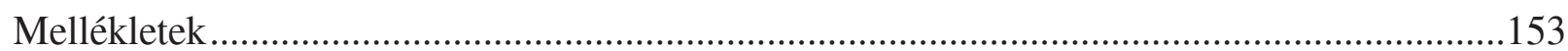




\section{Ábrák jegyzéke}

1. ábra: Pozitív visszacsatolási folyamat a Centrum-Periféria modellben............................................. 16

2. ábra: Agglomeráció és/vagy koncentráció Brakman és társai értelmezésében..................................22

3. ábra: Agglomeráció és/vagy térbeli koncentráció Lafourcade és Mion értelmezésében .....................23

4. ábra: Az iparban és építőiparban foglalkoztatottak eloszlása az nemzetgazdaság egészében foglalkoztatottakhoz képest (LQ értékek) Budapesttel.....

5. ábra: Az iparban és építőiparban foglalkoztatottak eloszlásának térbeli autokorrelációja az nemzetgazdaság egészében foglalkoztatottakhoz képest (LISA index értékek alapján) Budapesttel...

6. ábra: Az iparban és építőiparban foglalkoztatottak eloszlása az nemzetgazdaság egészében foglalkoztatottakhoz képest (LQ értékek) Budapest nélkül

7. ábra: Az iparban és építőiparban foglalkoztatottak eloszlása térbeli autokorrelációja az nemzetgazdaság egészében foglalkoztatottakhoz képest (LISA index értékek alapján) Budapest nélkül

8. ábra: A szolgáltatási szektorban foglalkoztatottak eloszlása az nemzetgazdaság egészében foglalkoztatottakhoz képest (LQ értékek) Budapesttel.....

9. ábra: A szolgáltatási szektorban foglalkoztatottak eloszlásának térbeli autokorrelációja az nemzetgazdaság egészében foglalkoztatottakhoz képest (LISA index értékek alapján) Budapesttel...

10. ábra: A szolgáltatási szektorban foglalkoztatottak eloszlása az nemzetgazdaság egészében foglalkoztatottakhoz képest (LQ értékek) Budapest nélkül

11. ábra: A szolgáltatási szektorban foglalkoztatottak eloszlásának térbeli autokorrelációja az nemzetgazdaság egészében foglalkoztatottakhoz képest (LISA index értékek alapján) Budapest nélküil

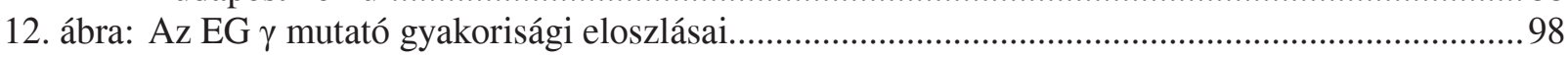

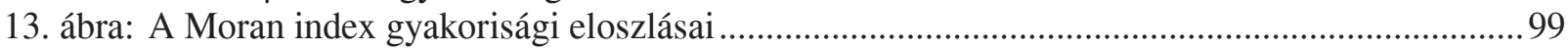

14. ábra: A Húsfeldolgozás alágazat LQ értékeinek térbeli eloszlása ................................................109

15. ábra: Kistérségek osztályozása Húsfeldolgozás alágazat lokális Moran I értékei alapján................110

16. ábra: A Közúti gépjármü, gépjármümotor alkatrészeinek gyártása alágazat LQ értékeinek térbeli eloszlása......

17. ábra: Kistérségek osztályozása Közúti gépjármü, gépjármümotor alkatrészeinek gyártása alágazat lokális Moran I értékei alapján .......................................................................... 112

18. ábra A Vegyi anyag, termék gyártása ágazat LQ és LISA index értékei, Budapest adatainak figyelembevételével...

19. ábra: A Vegyi anyag, termék gyártása ágazat LQ és LISA index értékei Budapest adatainak figyelembevétele nélkül.

20. ábra: A Gyógyszergyártás ágazat LQ és LISA index értékei Budapest adatainak figyelembevételével

21. ábra: A Gyógyszergyártás ágazat LQ és LISA index értékei Budapest adatainak figyelembevétele nélkül.

22. ábra: Az Információ-technológiai szolgáltatás ágazat LQ és LISA index értékei Budapest adataival.

23. ábra Az Információ-technológiai szolgáltatáságazat LQ és LISA index értékei Budapest adatai nélkül.

24. ábra: A Pénzügyi közvetítés, kivéve biztosítási, nyugdíjpénztári tevékenység ágazat LQ és LISA index értékei Budapest adataival.....

25. ábra: A Pénzügyi közvetítés, kivéve biztosítási, nyugdíjpénztári tevékenység ágazat LQ és LISA index értékei Budapest adatai nélkül. 


\section{Táblázatok jegyzéke}

1. táblázat: A gazdasági tevékenységek térbeli koncentrációjának elemzésére szolgáló mutatószámok .....

2. táblázat: A gazdasági tevékenységek agglomerációjának elemzésére szolgáló mutatószámok

3. táblázat:

Megyék osztályozása az autóipar szempontjából

4. táblázat: A vizsgált feldolgozóipari ágazatok (2 jegyü) és alágazatok (3 jegyü).....

5. táblázat:

A vizsgált 43 feldolgozóipari alágazat térbeli koncentráltsága az Ellison-Glaeser

$\gamma$ mutató értékek alapján.

6. táblázat:

A vizsgált 43 feldolgozóipari alágazat agglomeráltsága Moran index értékek alapján.

7. táblázat: Korrelációk és átlagok eltérése a Budapest adataival és az azok nélkül számított EG $\gamma$ mutató értékek között.....

8. táblázat:

Korrelációk és átlagok eltérése a Budapest adataival és az azok nélkül számított Moran index értékek között.

9. táblázat: Korrelációk és átlagok eltérése az ipar-építőiparhoz, illetve a nemzetgazdaságban foglalkoztatottakhoz viszonyítva számított EG $\gamma$ mutató értékek között .....

10. táblázat: Korrelációk és átlagok eltérése az ipar-építőiparhoz, illetve nemzetgazdaságban foglalkoztatottakhoz viszonyítva számított Moran index értékek között.....

11. táblázat: Tudásintenzív feldolgozóipari ágazatok az OECD (2001) osztályozása szerint.....

12. táblázat: Két független mintás t-próba eredmények a tudásintenzív és nem tudásintenzív feldolgozóipari alágazatok EG $\gamma$ átlagainak összehasonlítására

13. táblázat: Két független mintás t-próba eredmények a tudásintenzív és nem tudásintenzív feldolgozóipari alágazatok Moran index értékei átlagainak összehasonlítására ...

14. táblázat: Az EG $\gamma$ mutató és Moran index feldolgozóipari alágazatokon felvett értékenek átlagai a tudásintenzitás függvényében.

15. táblázat: Térbeli koncentráció és agglomeráció a vizsgált feldolgozóipari ágazatokban Budapest adataival az iparban és építőiparban foglalkoztatottak térbeli eloszlásához viszonyítva

16. táblázat: Térbeli koncentráció és agglomeráció a vizsgált feldolgozóipari ágazatokban Budapest adatai nélkül, az iparban és építöiparban foglalkoztatottak térbeli eloszlásához viszonyítva

17. táblázat: Korreláció az EG $\gamma$ mutató és a Moran index értékek között......................................... 108

18. táblázat: A Húsfeldolgozás alágazat mutatószám-értékei............................................................. 108

19. táblázat A Közúti gépjármü, gépjármümotor alkatrészeinek gyártása alágazat mutatószám-értékei

20. táblázat: A kistérségek lokális mutatók alapján történő osztályozása a térképeken és azok értelmezése.

21. táblázat:

A tudásintenzív ágazatok OECD által definiált osztályozása

22. táblázat: A tudásintenzív ágazatok térbeli koncentrációja és agglomerációja Budapest adatainak figyelembevételével

23. táblázat: A tudásintenzív ágazatok térbeli koncentrációja és agglomerációja Budapest adatainak figyelmen kívül hagyása mellett

24. táblázat: Térbeli koncentráció a tudásintenzív feldolgozóipari ágazatokban . Agglomeráció a tudásintenzív feldolgozóipari ágazatokban.....

31. táblázat: A Pénzügyi közvetítés, kivéve biztosítási, nyugdíjpénztári tevékenység ágazat mutatószám értékei. 


\section{ELŐSZÓ}

Első diplomám megszerzésekor még nem gondoltam, hogy majdani disszertációm közgazdaságtani szakterületen fog íródni, azonban már matematikus hallgatóként is vonzott a valószínüség-számítás és a statisztika világa, de a térképek és a grafikus ábrázolás szeretete is gyerekkoromra nyúlik vissza. Éppen ezért úgy gondolom, hogy választott témám jól ötvözi érdeklődési területeimet, hiszen közgazdaságtani tanulmányaim során Lengyel Imre segítségével bepillantást nyerhettem a gazdaság térbeliségének engem különösen megragadó oldalaiba. Doktoranduszként kezdtem el ökonometriát oktatni, és a térbeliség fokozatosan szivárgott be munkáimba. Az első komolyabb ökonometriai tárgyú tanulmányom már egy olyan regressziós modellt tartalmazott, melynek területi vonatkozásai elég erőteljesek: a piramis modell Lukovics Miklós által indikátorokkal feltöltött rendszerét vizsgáltam Magyarországon, kistérségi szinten. Miután „ráéreztem” a területi mozgóátlag számításának szükségességére, habár a fogalmat akkor még nem ismertem, rádöbbentem, hogy ez az a terület, amely engem leginkább vonz: a térstatisztika és térökonometria világa.

A gazdaság térbeliségének tematikája, ezen belül is konkrétan egy mutatószám, az Ellison-Glaeser $\gamma$ mutató megismerése után lassanként kezdett kibontakozni előttem a kép arról, hogy disszertációmat a gazdaság területi eloszlásának mérési módszereiről szeretném írni, amelyek igen sokszínűek, és amelyek közül néhányat a magyar gazdaságra alkalmazok. Teszem ezt olyan térfelosztási szinten, amelyet ilyen vizsgálatokban Magyarországon még kevésbé alkalmaztak. A sorban megszülető tanulmányaim, cikkeim készítése közben nagyon sokat tanultam a gazdaságról, a térbeliségről, az externáliákról, a definiálás fontosságáról, a tudásról és tanulásról (mind tudományos, mind pedig személyes szempontból). Arról is, hogy a téma rendkívül szerteágazó, és arról, ami a mottómban is szerepel, hogy igyekezzek a számítási eredményeimre nyitott szemmel ránézni, nem elfogultan, mely szemlélet eredményeképpen olyan dolgokra is felfigyelhetek, amelyekre korábban nem számítottam, nem is beszélve arról, hogy így a hibák is sokkal egyszerübben kiküszöbölhetők.

Disszertációm megírásáig vezető úton nagyon sok segítséget kaptam családomtól, barátaimtól, távolabbi és közvetlen munkatársaimtól. Először is férjemnek, Petinek és gyerekeimnek, Noéminek és Flóriánnak, Édesanyámnak, Édesapámnak, húgomnak, Elvirának és férjem szüleinek szeretném köszönetemet kifejezni a szeretetért, bátorításért, a mellettem állásért, egy-egy mosolyért, erőt adó mondatokért és azért a sok-sok türelemért, amellyel felém fordultak és támogattak. 
Nagyon nagy hálával tartozom témavezetőimnek, Lengyel Imrének, akitől a dolgozatom megírása során rengeteg szakmai és lelki segítséget, sok jótanácsot és támogatást kaptam, és Krámli Andrásnak, aki a valószínűségszámítás és statisztika iránti szeretetem csíráit megérlelte bennem.

Köszönettel tartozom kollégáimnak a disszertációm alapját jelentő cikkeim értő kritikáiért, a közös munkáért és együtt-gondolkodásért: Bajmócy Zoltánnak, Dombovári Doloresnek, Fenyővári Zsoltnak, Kovács Péternek, Lukovics Miklósnak, Málovics Györgynek, Mozsár Ferencnek, Nagy Benedeknek és Vas Zsófiának. 


\section{BEVEZETÉS}

Amikor a laikus szemlélő rápillant a világ térképére, nem csupán a földtani erők által változatossá formált kontinenseket, domborzati viszonyokat és földrajzi adottságokat látja, hanem azt is, hogy a népesség és a gazdasági aktivitás térbeli sủrüsége is heterogén, így igen sokszínü képet mutat. Hogy miért nem kiegyensúlyozott ez a területi eloszlás, annak igen összetett okai vannak. Természetesen közrejátszanak ebben a természeti adottságok is, de a népesség koncentrálódása mégsem vezethető vissza minden esetben csupán ezekre a tényezőkre.

Az ókortól kezdve - eleinte a mezőgazdasági többlettermelésnek köszönhetően- mindig voltak olyan gazdasági, politikai, katonai, illetve tudományos erőt képviselő városok, mint a népesség térbeli sürüsödési pontjai, amelyek nagy jelentőséggel bírtak saját környezetükben, és saját idejükben (Fujita-Thisse 2002). Másrészt viszont az egyenlőtlenség és a koncentráltság foka erőteljesen és egyre gyorsuló mértékben nőtt. A népesség és a gazdasági tevékenységek térbeli koncentrálódására egy nagyon szembetủnő példa az európai lakosság városban lakó hányadának nagysága: a 14. századtól öt évszázadon keresztül ez az érték alig változott: 10\%ról mindössze 12\%-ra nőtt. A legutóbbi kétszáz évben viszont ez a mutató drasztikusan növekedett, ma már az európai népesség 68\%-a városban él (Eurostat 2011).

Mi változott ebben az utóbbi kétszáz évben, vajon mi indíthatta el ezt a térbeli koncentrálódásban megfigyelhető nagymértékű növekedést? Kézenfekvőnek látszik az ipari forradalmat okolni. A szállítás fajlagos költsége lecsökkent és egyre nagyobb hangsúlyt kapott a nagyipari, egy területre koncentrálódott termelés. Ez magyarázat lehet a térbeli koncentrálódás egyre növekvő mértékére, azonban a népesség már korábban is városokba tömörült, amely mögött sokféle más ok is lehet. Ezek lehetnek pszichológiai, szociológiai okok, közrejátszhatnak benne történelmi és politikai tényezők, de kulturális vagy földrajzi ${ }^{1}$ okok és gazdasági tényezők is. Ez a felsorolás természetesen nem teljes, sőt a kép még akkor sem lenne túl egyszerü, ha csupán e hatóerők irányítanák a népesség és a gazdaság koncentrálódását, ezek a tényezök ugyanis nem önállóan hatnak, de egymásra is befolyással bírnak.

Az elméleti közgazdászok figyelmét a gazdasági tevékenységek térben egyenlőtlen eloszlása már korán kivívta, eleinte azonban főként az okok vizsgálata volt a cél: itt említhetjük Thünen, Weber, Lösch és Marshall munkásságát. Krugman (1995) öt olyan tradicionális

\footnotetext{
${ }^{1}$ Ezek talán a legfeltünőbbek, például a világ népességének 50\%-a él tengerpartokon és folyóvölgyekben, a legritkábban lakott területek pedig a sarkköri, illetve sivatagi területek, az esőerdők és a magashegységek.
} 
irányzatot sorol $\mathrm{fel}^{2}$, amelyeknek szerves részét képezték a térhez kapcsolódó közgazdasági gondolatok, azonban sokáig hiányzott az az eszköztár, amelynek segítségével a gazdaság térbeliségének elemzését mélyrehatóbb módon lehetett volna elvégezni.

Az utóbbi 20 évben a regionális gazdaságtan hagyományos felfogását meghaladva az elméleti közgazdaságtudomány több irányzatában is utat tört magának a területiség fogalma, köszönhetően a számítástechnikában és a közgazdaságtanban bekövetkezett fejlődésnek. Itt kiemelhetjük Paul Krugman munkásságát, aki elméleti makromodellt állított fel a jelenség vizsgálatának jobb megértése érdekében. Közben egyre nagyobb hangsúlyt kapott a térbeli differenciáltság mérése, számszerűsítése, valamint az egyes vállalatokat egymás közelébe vonzó, illetve egymástól eltávolító erők mechanizmusának megértése, modellezése (Krugman 1995, 2000; Ellison-Glaeser 1997). Paul Krugman 2008-ban Nobel díjat kapott a nemzetközi kereskedelem mozgásainak és a gazdasági tevékenységek területi összefüggéseinek elemzéséért.

A gazdasági tevékenységek földrajzi, térbeli sürüsödését térbeli koncentrációnak, agglomerációnak vagy specializációnak szokás nevezni attól függően, hogy milyen szemszögből tekintünk rá. A jelenség mérésével foglalkozó szakirodalom eleinte a koncentrálódási, illetve szóródási mutatószámokat általánosította, a területi egységeket először önmagukban vizsgálva, de később egyre specializáltabb mutatószámok jelentek meg, ahogyan a velük szemben támasztott igények is szaporodtak, majd a területi egységek szomszédossági viszonyainak beépítésére is sor került. Ellison és Glaeser 1994-ben publikálták $\gamma$ mutatójukat, amely azután gyorsan alkalmazásra talált több európai ország gazdaságának vizsgálatában, miközben más módszerekkel - területi autokorreláció mérése - is bővült a gazdasági tevékenységek térbeli vizsgálatának eszköztára.

A gazdaság térbeli koncentrációját lehet bizonyos térfelosztási szintekhez kötni, de a gazdasági tevékenységek egy-egy sürüsödési pontja nem feltétlenül követi a térfelosztási rendszereket. A méréséhez azonban - ha nem kívánunk nagyon nehézkes és bonyolult technikákhoz folyamodni - mindenképpen érdemes folytonos tér helyett diszkrét elemekből álló teret feltételezni, vagyis konkrét térfelosztási szintet választani. Ez után pedig megvizsgálható, hogy az adott térfelosztási szint alkalmas-e egy-egy gazdasági tevékenység térbeli koncentrációjának kimutatására.

Kutatásom során a gazdasági tevékenységek térbeli eloszlásáról Magyarország esetében kistérségi szinten kívántam képet kapni. Azért tartom fontosnak e vizsgálatok elvégzését, mert

\footnotetext{
${ }^{2}$ Ezek a következők: - német geometriai irányzatok - társadalomfizikai irányzatok - a halmozódó oksági modellek - a lokális külső méretgazdaságosságot feltételező - és a földjáradék és földhasználat irányzatai.
} 
segítségével további elemzésekre és az eredmények gyakorlati hasznosítására nyílhat lehetőség. A vizsgálat eredményei felhasználhatók arra, hogy - speciálisan vagy általánosan rámutassanak a térbeli koncentrálódás okaira, következményeire, például regressziós vizsgálatok útján. Magyarország gazdaságának fejlettségére, a gazdaság térbeli szerkezetének további elemzésére ad lehetőséget. Mintegy pillanatképként rámutathat gazdasági fejlesztési lehetőségekre, szerepet kaphat a gazdaságfejlesztési stratégiaalkotás háttérelemzéseiben, valamint európai uniós és hazai gazdaságfejlesztési pályázatokban.

A gazdasági tevékenységek térbeli sűrüsödésének okait nem egyszerü feladat felfedni. Disszertációmban ezért leginkább arra törekszem, hogy áttekintsem a gazdasági tevékenységek területi eloszlásával kapcsolatos fogalomrendszert, az egyes fogalmakhoz kapcsolódó mérőszámokat és azok értelmezését, tehát módszereket mutassak be e térbeli egyenlőtlenségek detektálására. Dolgozatom tehát elsősorban módszertani és nem leíró gazdasági jellegü. A bemutatásra kerülő eszközök magyarországi adatokra történő alkalmazása módszertani kihívásokat is jelent, így vizsgálataim során felmerült speciális magyar tanulságok bemutatása is fontos részét képezi munkámnak.

A dolgozat öt fejezetre tagolódik. Az első fejezetben azokat a fogalmakat tekintem át, amelyeket a gazdasági tevékenységek térben egyenlőtlen eloszlásának leírására használ a szakirodalom. Ennek kapcsán bemutatok két koncepciót, amelyek a koncentráció és agglomeráció fogalmakat megkülönböztetik. A második fejezetben a jelenség vizsgálati módszertanát ismertetem a szakirodalomban használt mutatószámok alapján. A harmadik fejezet a korábban bemutatott mutatószámok nemzetközi szakirodalomban való megjelenéseit tekinti át, a negyedik fejezetben pedig négy mutatószám, és ezek eloszlásának vizsgálata alapján magyar feldolgozóipari alágazatok, valamint tudásintenzív ágazatok térbeliségét elemzem kistérségi szinten. Végül a dolgozat összegzésében mutatom be módszertani eredményeimet, módszertani megjegyzéseimet és téziseimet.

A disszertációmban bemutatott módszertani eszközök nem képesek azon okok azonosítására, amelyek a gazdasági tevékenységek térben egyenlőtlen eloszlásához vezettek vagy vezetnek, azonban valószínúsíteni tudják ezen okok jelenlétét, vagy hiányát, így további vizsgálatok kiindulópontját jelenthetik. Munkám megírása során nem volt célom gazdaságpolitikai fejlesztési javaslatok felvázolása, hanem minél alaposabb módszertani áttekintést kívántam megvalósítani, miközben igyekeztem feltárni a módszertan Magyarországra való alkalmazásának lehetőségeit és az ebből fakadó tanulságokat. 


\section{Térbeli eloszlás, koncentráció és agglomeráció}

A gazdaság, a jövedelem, a népesség tulajdonsága, hogy azok térben egyenlötlen eloszlásúak. Meglepő volna, ha nem így lenne. A Regionális elemzési módszerek címü tankönyv így ír erről: „Az egyenlőtlenség - pontosabban a nem-azonosság - a tér- és időbeliség alapkategóriája, ebből következően talán a legsokoldalúbban kutatott kérdésköre a területi vizsgálatoknak" (Nemes Nagy 2005, 105. o.) .

Az egyenlőtlenség fogalmához többnyire valamiféle - erkölcsi, politikai - értéktartalom kapcsolódik, viszont a jelenség leírására alkalmazhatók semleges jelentéstartalommal bíró fogalmak is, mint differenciáltság, tagoltság, heterogenitás, vagy koncentráltság, sürüsödés (Nemes Nagy 2005).

Ha most eltekintünk attól, hogy megmagyarázzuk, és egyszerüen csak az egyenlötlen eloszlás, mint jelenség vizsgálatára szorítkozunk, még akkor is sokféle megközelítési lehetőség kínálkozik. Egyrészt tekinthetünk rá úgy, mint egy ismérv különböző mértékű megjelenésére az egyes területi egységekben, amely esetben mind a magas, mind az átlagos, illetve alacsony értékek fontosak, másrészt - szóhasználatunkban láthatóan helyet kapnak a koncentráció és agglomeráció, illetve specializáció, sürűsödés fogalmak - vizsgálódhatunk úgy is, hogy elsősorban a magas, kiemelkedő értékeket vesszük figyelembe, miközben az alacsony ismérvértékek csak kontrasztként vannak jelen.

Az elemzés tárgya lehet maga a dinamikus folyamat, a változás, így az egyenlőtlen eloszlásra tekinthetünk pillanatképként, a folyamat egy állomásaként, de vizsgálhatjuk csak mint statikus elemet, eltekintve attól, hogy időben milyen irányú folyamatok zajlanak. Ennek megfelelően használhatjuk a differenciálódás-differenciáltság, a koncentrálódáskoncentráltság, agglomerálódás-agglomeráltság, specializálódás-specializáltság, és a sűrűsödés-sűrüsödött kifejezések közül a kutatási szempontunknak megfelelőt.

A koncentráció, illetve agglomeráció fogalmak, amennyiben gazdasági tevékenységek térbeli eloszlásáról van szó, többnyire egymás szinonimájaként jelennek meg, azonban több olyan megközelítés található, amely e két fogalmat megkülönbözteti (Lengyel-Rechnitzer 2004). A továbbiakban áttekintjük azokat az okokat, amelyek az egyenlőtlen eloszláshoz vezethetnek, az előbbiekben felsorolt - térbeli egyenlőtlenséghez kapcsolódó - fogalmakat, és azokat a koncepciókat is, amelyek ezeket egymástól különböző értelemben használják. 


\subsection{A gazdaság térbeli differenciáltsága mögött húzódó folyamatok}

Annak érdekében, hogy a nemzetközi szakirodalomban megjelenő, a gazdasági tevékenységek földrajzi eloszlásához kapcsolódó elemeket egy közös keretbe helyezhessük legyenek azok befolyásoló tényezök, vagy következmények -, tekintsük most át azokat a földrajzi, gazdasági és egyéb tényezőket, amelyek feltehetően befolyásolják a gazdaság térbeli eloszlását.

A gazdaság koncentrálódási folyamata több lépésben ment és megy még ma is végbe, és mindegyik lépcsőfok tekinthető oknak és következménynek is. Említhetjük itt a népesség eleve meglévő térbeli eloszlását, mint kiindulási alapot. Ezután a mezögazdasági termelésre alkalmas területek és az ipari nyersanyagok lelöhelyeinek térbeli eloszlása jöhet szóba, majd végül a a szolgáltatások és a kereskedelem sürüsödési pontjai.

Eredetileg földrajzi okok játszottak közre abban, hogy a népesség bizonyos területekre települt, folyóvölgyekbe, tengerpartra, olyan helyekre, ahol az élelmiszerszükségletét ki tudta elégíteni eleinte vadászat, halászat és gyűjtögetés, később pedig a mezőgazdasági tevékenységek által. A népesség és a mezőgazdaság térbeli szerkezete ezután még sokáig azonos volt.

Öt-hétezer évvel ezelőtt azonban a mezőgazdaság olyan szintre fejlődött, hogy már nem csak a termelőt és családját, hanem másokat is el tudott látni élelmiszerrel, vagyis többlettermelésre volt lehetőség (Fujita-Thisse 2002, Enyedi 2012), így kialakultak az első városok. Ennek oka tehát már gazdasági jellegü volt. A városi lakosság többé nem csak mezőgazdasággal foglalkozott, hanem más tevékenységekre is alkalmassá váltak, megjelentek a kézmüiparosok és kereskedők. Ekkor már léteztek nagy népességet koncentráló területek, de a gazdaság nem volt eléggé fejlett ahhoz, hogy jelentős térbeli koncentrációjáról beszélhetnénk.

Ez a kép lassan változott, és a mezőgazdaság, valamint az ipar és főként a kereskedelem fejlődésével egyre jelentősebb gazdasági gócpontok alakultak ki. Ezután következett be a városrobbanás időszaka, amelynek kezdeteként az ipari forradalmat lehet megjelölni és kiemelendő, hogy a városnövekedés és a gazdasági fejlődés két évszázadon át öszzekapcsolódott. Nyersanyagainak fellelhetősége alapján az ipar koncentrálódott egyes területekre, és létrejöttek a bányászati-nehézipari telepek, amelyek egy része később ugyancsak várossá fejlődött, tehát az ipar koncentrálódása maga után vonta a népesség-koncentráció emelkedését is a magasabb munkakínálat miatt (Enyedi 2012).

A magasabb népsürüség és az ipar koncentrációja életre hívta a szolgáltatások megjelenését és a kereskedelem bővülését is. Ezek térbeli eloszlása tehát egyértelműen a 
korábbiak gazdasági következménye ${ }^{3}$, mégis külön kiemelendő, mert fejlődésük és koncentrálódásuk tovább erősíti az ipar és a népesség koncentrálódását is.

E néhány elem egymást erősíti és a folyamat ciklikusan megy végbe. Az egyes különálló civilizációkban más-más időpontban történtek a változások. Ha egyszer egy város már kialakult és például az a földrajzi tényező, amiért éppen ott épült fel, ahol felépült, megszűnt, akkor sem szükségszerü a város eltünése. Tehát a koncentráció fennmaradásához már nem feltétlenül szükséges az eredeti tényező (a folyamat önfenntartó), sőt, ha közel azonos természeti adottságokkal rendelkező területeket vizsgálunk, a populáció nagysága még akkor is mutathat elképesztően nagy különbségeket. Itt tehát mindenképpen kizárható a földrajz szerepe, ekkor már történelmi, politikai, esetleg gazdasági okok játszanak szerepet a koncentrálódásban.

Megállapíthatjuk, hogy nem lehet kizárólag a domborzati és éghajlati viszonyokkal magyarázni a gazdasági aktivitás és a népesség egyes területeken való koncentrált jelenlétét, hiszen ez túl statikus szemléletet jelentene, ami a meglévő dinamikát egyáltalán nem magyarázná. Ezzel szemben a gazdasági tényezők - hatásait szemügyre véve - úgy tünik, már megfelelő rugalmassággal rendelkeznek, időben sokkal inkább változékonyak. Így - habár kizárólagos szerepet nekik sem lehet tulajdonítani - alkalmasabbak magyarázatnak.

Krugman (2000) a globalizációs folyamatok hatásait elemezve egy térbeliséget is figyelembe vevő elméleti makro-modellt állított fel, amelyben ellentétes irányban ható erők érvényesülnek: a térbeli koncentrálódást előidéző centripetális erők, valamint a térbeli diszperziót segítő centrifugális erők. Krugman modelljét szokás centrum-periféria modellnek is nevezni, amelyre a továbbiakban CP modellként hivatkozom (Krugman 1991b, 1995, 2000, Szakálné 2005a és 2005b).

A CP modellnek három fontos hajtóereje van, ezek közül kettő centripetális, egy pedig a centrifugális irányú. Az első az úgynevezett market access hatás, amely arra ösztönzi a termelőket, hogy a nagy piacukhoz közel termeljenek, a kisebb piac felé pedig exportáljanak. A második ilyen erő a cost of living hatás, amely a vállalatok telephelyválasztásának hatása a helyi élet költségességére. Abban a régióban ugyanis, ahol több terméket gyártanak, olcsóbb lesz az élet, hiszen a szállítási költséget a helyi jószágok esetében nem kell megfizetni. A harmadik erő, és egyben az egyetlen, amely a szóródás irányába hat, a market crowding hatás, amely a tökéletlen versenyben a vállalatoknak azt a törekvését tükrözi, hogy a relatíve kevés helybeli versenytárssal bíró területet válasszák. A modell mindhárom hatáshoz egy-egy

\footnotetext{
${ }^{3}$ Hiszen olyan helyszínekre kell települniük, hogy minél több ügyfelet tudnak kiszolgálni (Enyedi 2012).
} 
paramétert rendel, végül e három paraméter egymáshoz viszonyított értéke dönti el, milyen kép alakul ki.

A centripetális erők a CP modellben egymást erősítő tulajdonságúak, így a koncentrálódás két összekapcsolódó folyamat eredményeképpen jön létre, ezek közül az egyik a kereslethez, a másik pedig a költségességhez kapcsolható (1. ábra).

1. ábra: Pozitív visszacsatolási folyamat a Centrum-Periféria modellben

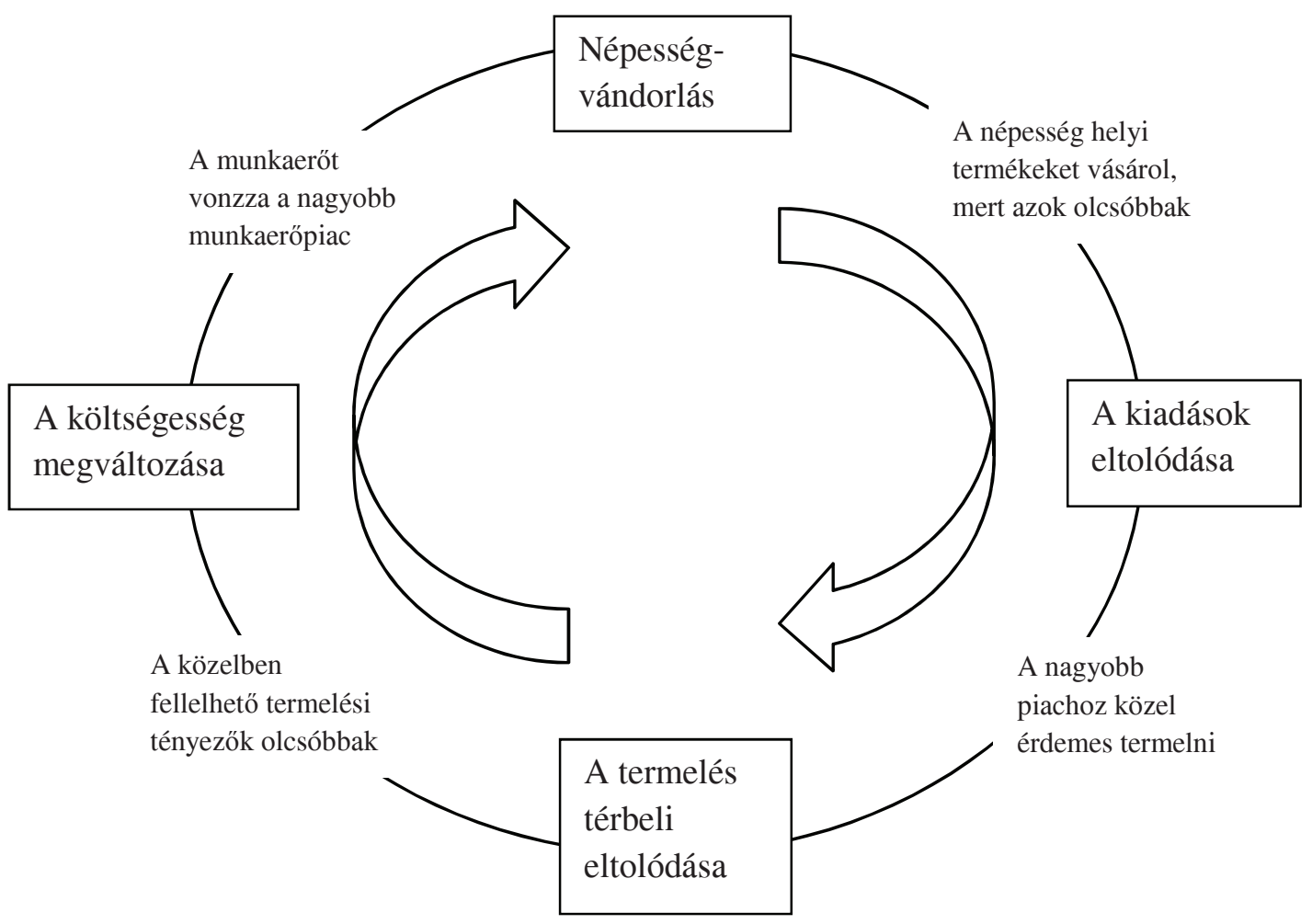

Forrás: saját szerkesztés Baldwin és társai (2003) alapján.

Megjegyzés: jobb oldalon a kereslet, bal oldalon pedig a költségesség által hajtott folyamatot láthatjuk.

A CP-modell eredménye szerint a szállítási költségnek van egy olyan szintje, amelyre mind az agglomeráció, mind pedig a szóródás stabil egyensúlyi állapot, sőt ha a szállítási költségek egy bizonyos szint alá csökkennek, akkor csak az agglomeráció a stabil állapot.

A Krugman által létrehozott új gazdaságföldrajzi modell után sok más, ebből kifejlesztett modell is napvilágot látott, amelyek azonban néhány alapvető feltételezés tekintetében megegyeznek. A térbeli koncentrálódást a csökkenö fajlagos szállítási költségek, a globális ágazatokban megfigyelhető növekvő mérethozadék és monopolisztikus verseny, valamint a pozitív lokális extern hatások idézik elő (Combes és társai 2008, Fujita és társai 1999, Fujita Thisse 2002, Henderson - Thisse 2004). A szakirodalomból adódó megállapítások: 
1. Az új gazdaságföldrajzi modelleknek egyik döntő momentuma a (csökkenő) szállítási költségek feltételezése, ugyanis e nélkül nem is kapna benne szerepet a földrajz.

Ha belegondolunk, hogy mi az eredeti oka annak, hogy a legtöbb város folyópartra vagy tengerpartra épül, könnyen rájöhetünk, hogy mivel korábban a szállítás egyik legfontosabb módja éppen a vízi úton történő árumozgatás volt, talán éppen a szárazföldi szállítás minimálisra csökkentése lehetett ez az ok. A szállítási költségek több módon is megjelennek mind a modellekben, mind pedig az elméleti alapokban. Közvetett módon a nyersanyagokhoz (ki)termelési helyétöl való távolság csökkentése és a termék piacának közelsége is éppen a szállítási költségek csökkentése miatt lehet fontos.

Az ipari forradalom előtt mind a szállítási költségek, mind pedig a szállítás időigénye magasak voltak, amelyek a vasút megjelenésével akár 95-98\%-os csökkenést is elérhettek (Combes és társai 2008). Tehát az ipari forradalom előtti időkben az ipar atomizált volt, mert a fogyasztókhoz közel kívánt elhelyezkedni a magas szállítási költség, mint szinte áthághatatlan akadály miatt. Az ipari forradalom megjelenésével, ahogy egyre olcsóbb lett a szállítás, az ipar egyre inkább koncentrálódott, mivel ekkor már inkább a nyersanyagokhoz közel helyezkedtek el a termelők. Ennek hatására a piacaik is odatelepültek, hiszen a fogyasztók egyben az ipar által alkalmazott egyik fö termelési tényezőt, a munkaerőt alkotják (Krugman 1991a, Combes és társai 2008).

A szállítási költségek szerepe azonban csökkent és továbbra is egyre csökkenő tendenciát mutat. A fajlagos szállítási és közlekedési költségek egyre kisebbek, így a földrajzi közelség egyre kevésbé fontos, a fizikai szállítás esetében is ez tapasztalható, de ugyanígy - az internet megjelenésével - egyes szolgáltatások is függetlenné váltak a konkrét földrajzi helytől, mivel az információ szállításának költsége, még inkább az időigényessége is drasztikusan csökkent. Ezzel szemben korábban a szolgáltatást végző vállalat és a vásárló egyazon földrajzi helyszínen kellett, hogy tartózkodjon (Lengyel 2010a).

2. A következő fontos feltételezés az új gazdaságföldrajzi modellekben a belső és külső méretgazdaságosság (economies of scale, increasing returns to scale).

A méretgazdaságosság fogalma olyan szituációt takar, amikor a kibocsátás szintjének növelése következtében a termék egységköltsége csökken. Ez egy monoton csökkenő átlagköltség-függvényt generál. Marshall (1920) annak érdekében, hogy meghatározza ennek az okát, különbséget tett a belső és külső méretgazdaságosság között.

A belső méretgazdaságosság esetén az átlagköltség csökkenése mögött a vállalat saját termelési szintjének növekedése áll. Minél többet termel a vállalat, annál több hasznot húz a 
növekvő mérethozadékból, és annál nagyobb költségelőnyre tesz szert a kisebb versenytársaival szemben.

A külső méretgazdaságosság esetében az átlagköltség csökkenése az ipari szintü termelési szintnövekedés számlájára írható. Itt az átlagköltség már nem csak a vállalati szintü kibocsátás függvénye. Marshall ezeket extern hatásoknak, másképpen külső gazdasági hatásoknak nevezte el. Ezek jellemzően lokálisak, szomszédsági hatásként jelentkeznek és immobilak (Lengyel-Mozsár 2002, Lengyel 2010a).

Scitovsky (1954) különbséget tett ezen kívül a tiszta (pure) vagy technikai és a pénzügyi külső méretgazdaságosság között. A tiszta méretgazdaságosság esetén az ipari szintü kibocsátás növekedése megváltoztatja a technológiai kapcsolatot a nyersanyagok és a termék között minden egyes termelőnél, vagyis a vállalatok termelési függvényére van hatással. Egy nagyon sokat emlegetett példa az először Alfred Marshall által megnevezett információ, vagy tudás túlcsordulás (Marshall 1920). A termelési szint növekedésével nő az ismeretanyag minden vállalatnál, illetve minden vállalat a létező ismeretanyagnak egy kicsit más szeletével rendelkezik, így minél több szereplő lép be a gyártás folyamatába, annál inkább felhalmozódik ez a tudás, ami technikai segítséget nyújt a termelés javításához. Mind a városgazdaságtanban, mind az új kereskedelmi elméletben ilyen méretgazdaságosságot feltételeznek. Ebben az esetben feltételezhető tökéletes verseny, hiszen az egyes vállalatok mérete nem számít (Brakman és társai 2009).

A pénzügyi külső méretgazdaságosság a piaci árhatáson keresztül jut el az egyes vállalatokhoz, amely befolyásolja a kibocsátás szintjét. Két példával tud szolgálni erre is Alfred Marshall: az egyik a speciális nyersanyagok helyi piaca (raw material concentration), a másik pedig a munkapiaci koncentráció (labour pooling) (Brakman és társai 2009).

A nagy ipartérségek lehetővé teszik a speciális köztes termékeket gyártó vállalatok létrejöttét és a jól képzett iparspecifikus munkaerő koncentrációját. Éppen ez a koncentrálódás oka, hiszen e jószágok termelése is fejlettebbé és olcsóbbá válik, így a végtermékhez szükséges inputok ára csökken. Ennek következtében az átlagköltség csökken, ami pedig maga után vonja a bérek növekedését, ez pedig egyrészt még több ipar-specifikus ismerettel rendelkező munkaerőt vonz a térségbe, másrészt a már helyben meglévő munkaerő is specializálódásra kényszerül. Az előzővel szemben ez a típusú külső méretgazdaságosság nem befolyásolja a 
termelési függvényt. Ez a típus csak tökéletlen versennyel együtt fordulhat elö, ami egybecseng az új gazdaságföldrajzi (New Economic Geography ${ }^{4}$ ) modellek feltételezéseivel:

3. A harmadik lényeges feltételezés a monopolisztikus verseny, amely tehát pénzügyi külső méretgezdaságosságot generál.

Tehát pézügyi külső méretgazdaságosságról van szó, amikor az új gazdaságföldrajzi modellek változatosság-kedvelö fogyasztókat feltételeznek ez pedig a monopolisztikus verseny Dixit-Stiglitz féle modellje.

Az elöbbiekben felsorolt típusok mind pozitív jellegüek voltak, de lehet a külső méretgazdaságosság negatív is, ilyenkor a vállalat kibocsátásának fokozása növelheti a többi vállalat egy egységre eső átlagköltségét. Ezek az új gazdaságföldrajzi modellekben tipikusan a centrifugális erők.

4. Végül megjelennek a modellekben a lokális extern hatások, amelyeket másként agglomerációs méretgazdaságossági elönyöknek (agglomeration economies of scale) lehet nevezni.

Ezt a fogalmat a regionális tudományban használják az előbbiekben leírt, a térbeli közelségből fakadó előnyök leírására (Lengyel 2010a). Ez a fogalom a „gazdasági tevékenységek során a vállalatok, illetve a tevékenységek egymáshoz közeli elhelyezkedéséböl fakadó költség-megtakarítások"-at takarja (Pearce 1993, 28. o.). E tudományágon belül az agglomerációs méretgazdaságossági előnyöket három fő típusba sorolják ${ }^{5}$, amelyek a következők (Parr 2002, Lengyel 2010b):

- Tevékenység-komplexitási előnyök: az értékláncrendszert alkotó vállalkozások egymás melletti müködésének, földrajzi közelségének, szomszédságának kihasználása, általában egy integrátor vállalat és beszállítóinak térbeli tömörülése. A kiszervezett vállalatoknak előnyös a központ közelében müködni. Az előbbiekben bevezetett terminológiával élve ezekre egyszerủen, mint méretgazdaságosságra hivatkozhatunk.

- Lokalizációs elönyök (Marshall-Arrow-Romer (MAR) externáliák): ekkor olyan költségmegtakarításokról van szó, amelyek vállalaton kívüli okokból származnak, ezek viszont mind az iparág, mind pedig a térség számára belsők. Itt tehát az azonos iparágban tevékenykedő vállalkozások térbeli közelsége az előnyök forrása, például az iparágon belüli tudás-túlcsordulás következtében. Az ilyen

\footnotetext{
${ }^{4}$ Krugman (1991b) ezzel a névvel illette azt a megszületőben lévő tudományterületet, amely a gazdasági tevékenységek térbeliségének modellezésével foglalkozik.

${ }^{5}$ Ezek mindegyike lehet akár külső, akár belső méretgazdaságossági előny is.
} 
extern hatások miatt a térség az adott tevékenységre specializálódik, vagyis a térség gazdaságában az iparág nagyobb szerepet kap, mint általában a többi iparág.

- Urbanizációs előnyök (Jacobs externáliák): ezek olyan mérethozadékot takarnak, amely a város nagy méretéből, vagy sürüségéből fakadnak, ez pedig meglehetősen változatos gazdasági összetételt, több iparág együttes jelenlétét eredményezi. Ekkor a területen belüli a technológiai diverzitás eredményez több különböző iparág közötti tudás túlcsordulást és ebből jelentős gazdasági előnyök adódnak.

\subsection{A gazdaság térbeli eloszlásához kapcsolódó fogalmak}

A gazdasági tevékenységek térbeli egyenlőtlen eloszlásának, a vállalkozások földrajzi tömörülésének lényegét megragadni kívánó fogalmakkal (koncentráció, agglomeráció, illetve specializáció) több, a témával szoros kapcsolatban álló tudományterületen is találkozhatunk.

Amint azt említettem, az agglomeráció fogalma a regionális gazdaságtanban az agglomerációból fakadó méretgazdaságosság, másként szólva agglomerációs méretgazdaságossági előnyök formájában jelentkezik. A fogalom társadalom-földrajzi megközelítése szerint pedig az agglomeráció egy összetömörült település-együttest, általában egy nagyvárost és vonzáskörzetét jelöli (Lengyel-Rechnitzer 2004, Pearce 1993). A korábban említett extern hatás a neoklasszikus közgazdaságtan egy fontos fogalma, ezzel szemben ,az agglomeráció főleg a regionális gazdaságtan és az üzleti (gazdálkodás) tudományok mủvelöi által használt fogalom" (Lengyel 2010b, 23. o.).

A statisztikában a koncentráció fogalma a teljes értékösszeg jelentős részének néhány sokasági egységre való összpontosulását jelenti (Hunyadi és társai 1996). Megkülönböztethetük abszolút és relatív koncentrációt. Az előbbi azt jelzi, hogy ,a teljes értékösszeg kevés számú egység között oszlik el” (Kerékgyártó 1980, 79. o.), az utóbbi esetben viszont „az értékösszeg egyenetlenül oszlik el a sokaság egységeire” (Kerékgyártó 1980, 79. o.). E definíciót esetünkre alkalmazva értékösszegként vehető például az iparágbeli összes foglalkoztatottak száma, vagy az összes hozzáadott érték, a sokasági egységek pedig az aktuális térfelosztási szint területi egységei. Így kapjuk meg a térbeli koncentráció fogalmát. Dolgozatomban többnyire relatív koncentráció-mérésről esik majd szó, hiszen térben „egyenetlen eloszlás”-t kívánok mérni

\footnotetext{
${ }^{6}$ Az abszolút és relatív koncentráció mérésénél felmerülő problémákkal foglalkoztak még Szanyi és társai (2009). 
A specializáció fogalma egyértelmủen egy térség, területi egység szempontjából vizsgálja a gazdasági tevékenységek sürüsödését. A fogalom a „tevékenység koncentrálása azokra a területekre, amelyeken a vállalatoknak, vagy egyéneknek természetes, vagy szerzett elönyük van” (Pearce 1993, 516. o.). Ez egyúttal azt is jelenti, hogy „a vizsgált régió gazdaságát a gazdaság egészétől eltérö iparszerkezet jellemzi” (Pearce 1993, 516. o.). A specializáció fogalma tehát egy más nézőpontot tükröz. Egy konkrét térség lehet specializált egy vagy több bizonyos iparágra, ezzel szemben egy iparág, vagy iparágak egy csoportja lehet agglomerálódott vagy térben koncentrálódott.

A térbeli koncentráció, illetve agglomeráció a gazdasági tevékenységek térbeli eloszlásának mérését célzó nemzetközi szakirodalomban többnyire ugyanazt jelöli. A két fogalom elkülönítésére azonban több kísérlet történt, amelyek közül kettőt emelnék ki.

Az első a vizsgált gazdasági tevékenységek körének mérete szerinti különbségtétel, amelyet Brakman, Garretsen és Marrewijk (2009) fogalmaztak meg. Erre a továbbiakban a szerzők neveinek kezdőbetűi alapján BGM megközelítésként fogok utalni ${ }^{7}$

A második esetében a térbeli koncentráció, illetve az agglomeráció fogalmakat attól függően használják, hogy csak a területi egységeken belül találjuk a tömörülést, vagy ez a határokon túlnyúlik, vagyis a területi egységek között is található kapcsolat. Ez utóbbi megkülönböztetést Lafourcade és Mion (2007) tanulmányában találjuk meg, erre a továbbiakban ugyancsak a szerzők neveinek kezdőbetủi alapján $L M$ megközelítésként fogok hivatkozni ${ }^{8}$.

\subsubsection{A vizsgált gazdasági tevékenységek köre (BGM)}

Mind a térbeli koncentráció, mind az agglomeráció egyes gazdasági tevékenységek térbeli eloszlásának egyenetlenségét írja le, azaz akkor használatos, ha a gazdasági tevékenységek egy bizonyos köre kevés földrajzi helyszínen összpontosul. A két fogalom annyiban különbözik egymástól Brakman és társai (2009) felfogásában, hogy míg a koncentráció szükebb csoportra, egy vagy legfeljebb néhány jól definiált ágazatra fókuszál, addig az agglomeráció a gazdasági tevékenységeknek már egy bővebb csoportját - akár az egész ipart - vizsgálja. E megközelítés szerint tehát attól függően, hogy a vizsgálni kívánt

\footnotetext{
${ }^{7}$ Brakman és társai (2009) Brülhart (1998) alapján a térbeli koncentráció, a specializáció és az agglomeráció fogalmak között tettek különbséget.

${ }^{8}$ Lafourcade és Mion (2007) Arbia (2001) térbeli koncentráció és térbeli polarizáció fogalmai alapján különböztették meg a térbeli koncentráció és agglomeráció fogalmakat.
} 
gazdasági tevékenységek köre milyen széles, a priori eldöntjük, hogy koncentrálódást vagy agglomerálódást vizsgálunk-e.

A két fogalom elkülönítése azért célszerű, mert a gazdasági tevékenységek térbeli tömörülése mögött rejlő hajtóerők is eltérnek egymástól. Térbeli koncentráció esetén a szükebb, az ágazatra vagy szakágazatra speciálisan jellemző centripetális erök hatása érvényesül. Ezek elsősorban lokalizációs előnyök, például különleges képzettségü munkaerő, az adott iparágon belüli tudástúlcsordulás, speciális infrastruktúra. Az agglomeráció viszont általánosabb erők következményeképpen jön létre, amelyek elsősorban urbanizációs előnyök lehetnek, például közlekedési csomópont, nagy helyi piac, illetve az alkalmazkodni képes munkaerö.

Nagyon fontos tényező ebben a fogalmi keretben az is, hogy milyen térfelosztási szintet alkalmazunk. Ami teljesül regionálisan, az nem feltétlenül érvényes magasabb térfelosztási szinten, például országosan.

A két fogalom eltérése a következőképpen szemléltethető. A 2. ábra 15 vállalat 4 régióban való telephelyválasztását mutatja két lehetséges módon. Az 1. és 2. régió alkotja Északot, a 3. és 4. régió pedig Délt. A baloldali ábrán minkét iparág koncentrálódik Északon és mindkét északi régióban külön-külön is, közben pedig az egész ipar is agglomerálódik Északon és mindkét északi régióban is. A jobboldali ábrán az I. iparág a 2. régióban és Északon, a II. iparág pedig Délen koncentrálódik. Az ipar ebben az esetben a 2. és 3. régiókban ugyan agglomerálódik, azonban Észak-Dél viszonylatában nem.

2. ábra: Agglomeráció és/vagy koncentráció Brakman és társai értelmezésében
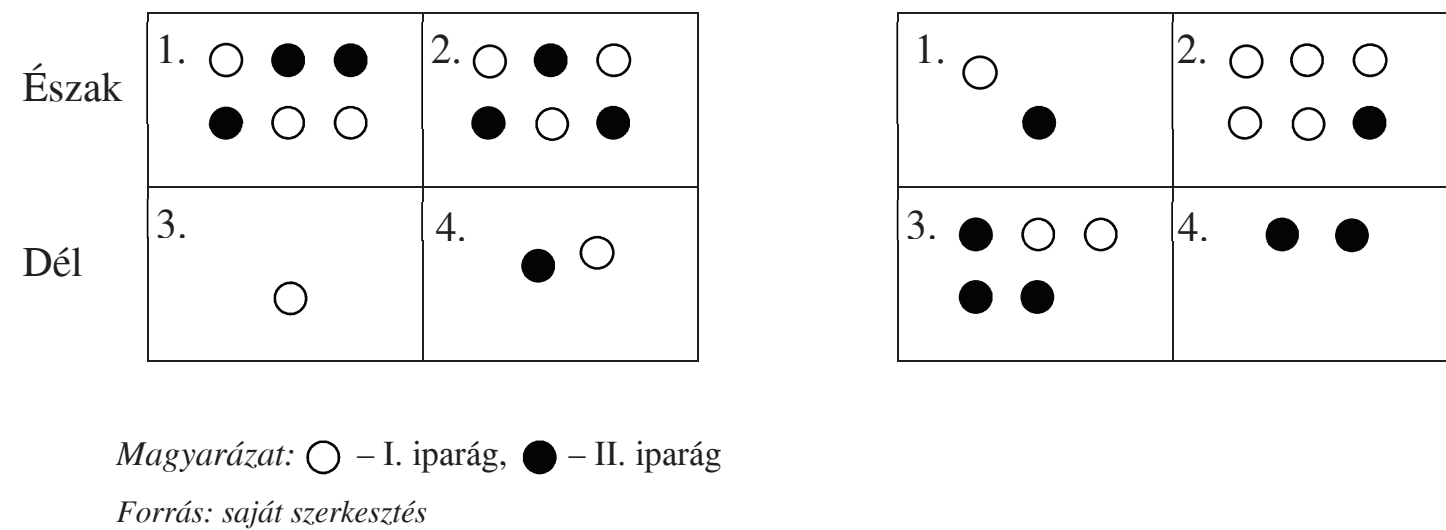

\subsubsection{Független területi egységek vs. területi autokorreláció (LM)}

Lafourcade és Mion (2007) mind a térbeli koncentráció, mind az agglomeráció fogalmakat használják a gazdasági tevékenységek tetszőleges csoportjára (szakágazatra, 
alágazatra, ágazatra, sőt akár egész szektorra, vagy ezek bármely részhalmazára is), azonban ők a mérőszámok alapján különböztetik meg ezeket. Nem csak ez a szerzőpáros, de mások ${ }^{9}$ is különbséget tesznek a kétféle mért tulajdonság között: a nemzetközi szakirodalomban is sokszor előfordul, hogy kettős rendszerü vizsgálatokat végeznek ${ }^{10}$, a térbeli koncentráció felméréséből ugyanis még nem lehet következtetni az eloszlás struktúrájára (Breschi 1998).

LM javaslata szerint a térbeli koncentráció kifejezést akkor alkalmazhatjuk, amikor a vizsgált iparágban, vagy iparágakban müködő vállalkozások egy-egy térségbe tömörülnek, amelyek lehetnek szomszédosak vagy akár izoláltak is. Ebben az esetben csak az a lényeges szempont, hogy két vállalkozás azonos területi egységben telepszik-e le, vagy sem. Ekkor a területi egységek szomszédsági viszonyait figyelmen kívül hagyjuk.

LM felfogása szerint az agglomeráció esetében a vállalkozások térbeli sürüsödése egymással szomszédos területi egységekbe történik, a területi egységek tehát a térfelosztásnak már nem különálló, diszkrét elemei, hanem egymással kapcsolatban levő egységek, ahol a kapcsolatot a térbeli közelség-távolság határozza meg. Ebben az esetben térbeli autokorrelációt mérünk, azaz azt vizsgáljuk, hogy a szomszédos területi egységek adatai hasonlók vagy eltérők.

Ez a fajta megkülönböztetés összhangban áll a koncentráció statisztikában megszokott, előzőekben említett definíciójával, hiszen ez alapján nem lényeges, hogy a vizsgálat alapjául szolgáló egységek térbeliek-e. Az agglomeráció társadalom-földrajzi definíciójával is összeegyeztethető a két fogalom elkülönítése, ugyanis itt is egy területi egységröl és „,vonzáskörzetéről” van szó, amelyben egy gazdasági tevékenység hangsúlyosan van jelen.

3. ábra: Agglomeráció és/vagy térbeli koncentráció Lafourcade és Mion értelmezésében

\begin{tabular}{|c|c|}
\hline $\begin{array}{r}\circ \circ \\
\circ\end{array}$ & $\begin{array}{r}0 \\
0 \\
0\end{array}$ \\
\hline 00 & $\begin{array}{ll}0 & 0 \\
0\end{array}$ \\
\hline & \\
\hline
\end{tabular}

\begin{tabular}{|c|c|c|}
\hline & $\begin{array}{r}0 \\
0 \\
0\end{array}$ & \\
\hline $\begin{array}{cc}0 & 0 \\
0\end{array}$ & & $\begin{array}{r}\circ 0 \\
0\end{array}$ \\
\hline & $\begin{array}{r}0 \\
0 \\
0\end{array}$ & \\
\hline
\end{tabular}

Forrás: Lafourcade-Mion (2007) 49. o. alapján saját szerkesztés.

A két fogalom LM megközelítésében való összefüggését láthatjuk a 3. ábrán, amely 12 vállalat 9 területi egységben való kétféle eloszlását mutatja. Mindkét esetben azonos mértékü térbeli koncentrációról van szó, hiszen a 12 vállalat mindkét esetben 4-4 területi egységben

\footnotetext{
${ }^{9}$ Guillain és Le Gallo (2007) mindkét fogalmat ebben az értelemben használja minden további magyarázat nélkül.

${ }^{10}$ Sohn (2004), Carroll és társai (2008), Arbia és társai (2006), a kettős rendszerủ vizsgálatokról lásd bővebben: 3.3 fejezet.
} 
található egyenletes elosztásban. Azonban, míg a bal oldali esetben agglomerációról beszélhetünk, hiszen a szomszédos területi egységek hasonlóak, addig a jobb oldali esetben agglomeráció nem áll fenn, mivel a szomszédos területi egységek adatai szisztematikusan különböznek egymástól.

Lafourcade és Mion (2007) vizsgálatai szerint azért érdemes megkülönböztetnünk az agglomeráció és a koncentráció fogalmát, mert a vállalkozások mérete szoros összefüggésbe hozható azzal, hogy a térbeli tömörülés melyik formája valósul meg. E szerint csak a posteriori dől el, hogy - a centripetális erők hatókörének nagyságától függően - a vizsgált gazdasági tevékenységek köre agglomerálódik és/vagy koncentrálódik.

A térbeli sürüsödés szempontjából természetesen lényeges, hogy azok a területek, amelyekben a kérdéses gazdasági tevékenység koncentrálódik, inkább szomszédosak, vagy pedig térben elszórtan helyezkednek el. Ez egyúttal azt is jelenti, hogy egy ágazat agglomeráltságának és térbeli koncentráltságának mértékét összehasonlítva meghatározható az a térfelosztási szint, amely mellett az ágazat egyes vállalatait egymáshoz vonzó erők hatósugara mérhetővé válik. Az agglomerálódás tehát a mérés alapjául szolgáló térfelosztási szintnél legalább egy szinttel feljebb már esetleg koncentrálódásként érhető tetten. A 3. ábrán látható esetekben ez a következőt jelenti:

- Ha a bal oldali ábrának megfelelő a területi eloszlás, akkor arra következtethetünk, hogy a sürüsödés okának nevezhető erők hatósugara nagyobb, mint a választott területi felosztási szint (települési, kistérségi vagy megyei) egységeinek sugara.

- Ha a négy azonos mértékben koncentrált területi egység elhelyezkedése véletlenszerü, vagyis valamilyen, a két eset közötti átmeneti eloszlás valósul meg, akkor az előbb említett hatósugár a területi egységek méreténél kisebb, vagy egyenlő azzal.

- Ha viszont a területi eloszlás a jobb oldali képnek megfelelő, akkor a vállalatokat egymáshoz vonzó (centripetális) erők hatósugara a területi egységek méreténél kisebb, vagy egyenlő azzal, sőt a szisztematikus szétszóródás már inkább olyan taszító (centrifugális) erők jelenlétét valószínűsíti, amelyek hatósugara túlnyúlik a területi egységek határán. 


\subsubsection{A két megközelítés összevetése}

A két megközelítést (BGM és LM) összevetve a következő kapcsolatot találhatjuk köztük: a BGM koncepció attól függően, hogy a vizsgált gazdasági tevékenységek köre milyen széles, a priori eldönti, hogy koncentrálódást vagy agglomerálódást vizsgálunk-e. LM megközelítése szerint viszont csak a posteriori dől el, hogy - a centripetális erők hatókörének nagyságától függően - a vizsgált gazdasági tevékenységek köre agglomerálódik, és/vagy térben koncentrálódik.

A további kapcsolat abban nyilvánul meg, hogy feltehetően található olyan térfelosztási szint, amely mellett az egész ipar agglomerálódása várhatóan magasabb fokú LM értelemben is, mint egyes iparágaké, miközben az iparágak LM értelemben térben koncentrálódnak, de nem agglomerálódnak. Ez azért lehetséges, mert az egész ipart területileg összetartó urbanizációs erők (előnyök) hatósugara várhatóan nagyobb, mint az egy-két iparágra speciálisan jellemző lokalizációs összetartó erőké (előnyöké).

Dolgozatomban a továbbiakban a vizsgálati céljaimnak megfelelőbb LM megközelítést fogom alkalmazni, vagyis - ha mást nem hangsúlyozok, akkor - mind az agglomerálódás, mind a koncentrálódás fogalmát LM értelemben fogom használni. Ennek elsőrendủ oka az, hogy a mutatószámok is két csoportba oszthatók: térbeli összefüggéseket figyelembe vevőkre és azokat figyelmen kívül hagyókra. Előrebocsátom, hogy esetenként még visszautalok egyik, vagy másik megközelítésre.

\subsection{A fejezet föbb megállapításai}

A közgazdasági gondolkodásban korábban és újabban megjelent folyamatok és fogalmak, amelyek a gazdasági tevékenységek térbeli eloszlásához szervesen kapcsolódnak tehát a következők.

Először is lényegesek azok az alapvető földrajzi elemek és történelmi, valamint gazdasági folyamatok, amelyek a múltban közrejátszhattak a népesség és gazdaság egyre fokozódó térbeli koncentrálódásában. A közgazdasági gondolkodásban megjelentek a gazdaság egyenlőtlen térbeli eloszlását leírni kívánó makro-modellek alapvető feltételezései: - csökkenő fajlagos szállítási költségek, növekvő mérethozadék, monopolisztikus verseny és lokális extern hatások.

Dolgozatomban a kulcsfontosságúnak tekinthető fogalmaknak, mint koncentráció és agglomeráció, az egyes diszciplínákban eltérő definícióik találhatók, amelyek közül két 
koncepciót kiemelten fontosnak tartok, ezek a két fogalom térbeli változatai között tesznek különbséget:

1. BGM (Brakman-Garretsen-Marrewijk) a vizsgált gazdasági tevékenységek köre szerint különbözteti meg a két fogalmat.

2. LM (Lafourcade-Mion) aszerint nevezi a gazdasági tevékenységek egy körét agglomeráltnak és/vagy térben koncentráltnak, hogy a kimutatásukra használt méröszámok közül melyik mutat térbeli egyenlőtlenséget.

Mivel céljaimnak ez utóbbi különbségtétel - az LM megközelítés - felel meg jobban, ezért a dolgozatom további részében a gazdasági tevékenységek agglomerálódására és térbeli koncentrálódására e koncepció szerint fogok hivatkozni. A továbbiakban Lafourcade és Mion (2007) fogalomrendszerét követve:

- Térben koncentrált egy ágazat, ha az ágazatbeli vállalkozások egy-egy térségbe tömörülnek, amelyek lehetnek szomszédosak vagy akár izoláltak is;

- Egy ágazat agglomerált, ha az ágazatbeli vállalatok néhány olyan területi egységbe tömörülnek, amelyek szorosabb térbeli kapcsolatban ${ }^{11}$ állnak egymással, vagyis pozitív térbeli autokorreláció áll fenn.

\footnotetext{
${ }^{11}$ E kapcsolat szorosságát a térbeli közelség/távolság határozza meg.
} 


\section{Az ágazatok térbeli koncentráltságának, illetve agglomeráltságának vizsgálati módszertana}

Amint kiemeltük, a gazdasági tevékenységek egyenlőtlen térbeli eloszlásának sokféle oka lehet. Speciális helyi adottságok, természeti, társadalmi és gazdasági tényezők is állhatnak mögötte. Vizsgálatunk célja ugyan a gazdasági tényezők hatásának felmérése, ezt azonban nehéz elválasztani sok egyéb lehetséges hatástól. Ha azonban müködnek az ágazatban ilyen, a térbeli sűrüsödés irányába ható erők, akkor ezeknek mind meglétét, mind pedig hatósugarát valószínűsíteni tudjuk a mérőszámok kiértékelésének segítségével.

Egy ágazat térbeli szerkezetének vizsgálatához a korábbiakban tisztáztuk a térbeli koncentráció és az agglomeráció fogalmát. Térbeli koncentrálódás mérése esetén a területi egységek szomszédsági viszonyait figyelmen kívül hagyjuk. Agglomerálódás vizsgálata esetén pedig azt elemezzük, hogy a szomszédos területi egységek adatai a vállalatok koncentráltságát tekintve hasonlóak-e (vagy eltérők).

A vállalkozások telephelyének kiválasztásakor befolyásoló tényező lehet, hogy a többi vállalkozás hol müködik, esetenként fontos lehet számukra a többi vállalkozástól mért távolság optimalizálása. Már Marshall is „...a telephelyválasztás fö motívumának az olyan fizikai feltételeket tekintette, mint az éghajlat, a termöföld, vagy az ásványi anyagok és szállítási lehetöségek megléte, de kitért a szakmai tapasztalatok generációkon átívelö felhalmozódására (hereditary skills), a kapcsolódó tevékenységek (subsidiary trades) kifejlödésére, a specializált eszközök nagyobb termelési volumennek köszönhetö bevethetöségére, illetve a speciális szakmák piacainak kialakulására is.” (Mozsár 2000, 101. o.). Ez utóbbiak pedig mind a többi vállalat müködésének helyszínétől függő tényezők.

A területi eloszlás-vizsgálatok során mindig távolságról esik szó, amely megengedne folytonos térről való gondolkodást is, de vizsgálataim során - mint ahogy azt a bevezetőben már kiemeltem - a teret mégis véges sok diszkrét pontból (területi egységből) álló halmazként kezelem, amely pontok között térkapcsolatok (szomszédság, távolság) lehetnek ${ }^{12}$.

A gyakorlatban a térbeli koncentráció és agglomeráció mérésére többféle lehetőség kínálkozik. A munkatermelékenység és a munkaerő sűrüsége között pozitív korreláció mérhető

${ }^{12}$ [A térfelosztásnál] „... diszkrét és folytonos térelemekből álló, egyszerre folytonos és egyszerre diszkrét térrel állunk szemben. Ez azt jelenti, hogy a társadalmi tér lényege szerint sem nem kizárólagosan folytonos, sem nem kizárólagosan diszkrét, hanem ez a két tulajdonság más-más nézőpontokból szemlélve lesz jellemző rá." (Dusek 2004, 69. o.) 
(Ciccone-Hall 1996), így a gazdaságfejlesztési és munkahely-teremtési célzattal végzett vizsgálatok, tanulmányok esetén a térbeli sürüsödés mértékét többnyire foglalkoztatottsági adatokon alapuló mérőszámokkal szokták mérni (Lafourcade-Mion 2007). Éppen ezért az elemzések során én is vállalati létszámadatokat vettem figyelembe.

A kutatók más-más okokból vizsgálják a gazdaság területi differenciáltságát, ezért az általuk kidolgozott mutatószámok tartalma és módszertani használata is jelentősen eltérhet egymástól. Ennek alapján, mint említettem, két fó irányban határozható meg az elemzések eszköztárának fejlődése is.

1. Független területi egységek. A térbeli koncentráció mérése esetében bizonyos térfelosztási szint mellett az egyes területi egységekbe jutó gazdasági tevékenység kirívóan magas, illetve alacsony értékeit vizsgáljuk, attól függetlenül, hogy azok földrajzilag hol és hogyan helyezkednek el egymáshoz képest.

2. Területi autokorreláció. Az agglomerációhoz kapcsolódó vizsgálatok célja ugyancsak a gazdasági tevékenységek egy vagy több területi egységbe való tömörülésének detektálása, itt azonban már az egységek földrajzi elhelyezkedése, közelsége, szomszédsági viszonyai is fontos szerepet játszanak.

Bár a gazdasági tényezők koncentráló hatásait nehéz mérni, a következőkben bemutatott és használt mutatószámok összességében számos kritériumnak megfelelnek (DurantonOverman 2005): úgy, mint iparágak összevethetősége, térbeli és ágazati koncentráció egyidejü mérése, a skálázásra és térbeli aggregációra nézve torzítatlan becslés és egyúttal a kapott eredmények szignifikancia szintjét is megadják.

\subsection{A térbeli koncentráció mérése}

A térbeli eloszlás mérése, ezen belül is a térbeli koncentrációé, elöször az általános koncentrációs mutatószámok általánosításával valósult meg. Az ipari koncentráció méréséről magyar nyelven Tüü Lászlóné (1980) írt egy átfogó tanulmányt, ebben a müben azonban térbeliségre való utalást még nem találunk, a mutatószámok alkalmazásának célja egyértelműen az ismérvértékek vállalatokban, mint megfigyelési egységekben való eloszlásának felmérése. A tanulmányban megjelenő relatív koncentrációt mérő mutatók nagy része alkalmazható térbeli eloszlási vizsgálatban is, mint ahogy ezt meg is tették az egyes szerzők nemzetközi és magyar tanulmányokban is. A Gini féle koncentrációs index területi kiterjesztését például Krugman 
(1991b), a Herfindahl index területi változatát Breschi (1998) és Frank (2008), az entrópiát pedig Lengyel és Leydesdorff (2008) alkalmazta.

E mutatószámokon túl azonban megjelentek olyanok is, amelyeket már kifejezetten a térbeli koncentráció mérésének céljával fejlesztettek ki. Ezek között említhetjük a $\gamma$ mutató Ellison és Glaeser (1994), valamint Maurel és Sédillot (1999) által létrehozott változatát, és a lokációs hányadost (LQ).

A felsoroltak közül három globális mutatószám alkalmazása a leggyakoribb, ezek a Herfindahl index, a Gini mutató és az Ellison Glaeser $\gamma$ mutató. Mindhárom mutatószámnak vannak előnyei és hátrányai is, ezeket a mutatók részletes bemutatásánál fogom jelezni.

Ezen túl - mivel az ágazat térbeli eloszlásáról nem kizárólag globálisan szeretnénk tájékozódni - mindenképpen érdemes lokális mutatót is alkalmazni, amely az egyes területi egységekre lebontva ad képet az adott ágazatról.

\section{Lokációs hányados (Location Quotient - LQ)}

Fontos, a térbeli sürüsödés-vizsgálatoknál leggyakrabban használt mutató a foglalkoztatási adatok esetében az $L Q$ mutató. Ez „egy bizonyos gazdasági tevékenység (ágazat, alágazat) egy adott térség gazdaságában való - a nemzetgazdaság egészéhez vagy egy szűkebb tevékenységi körhöz viszonyított - alul- vagy túlreprezentáltságának statisztikai mérőszáma" (Pearce 1993, 336. o.). Mint neve is mutatja, lokális mutatószám, tehát minden vizsgált területegységre ad egy számértéket.

$$
L Q_{i}=\frac{e_{i a ́} / E_{\mathrm{a}}}{e_{i} / E}=\frac{s_{i}}{x_{i}}
$$

ahol

$e_{i a ́} \quad-$ az $i$-edik területi egységben, az adott ágazatban foglalkoztatottak száma,

$e_{i} \quad-$ az $i$-edik területi egységben foglalkoztatottak száma,

$E_{\text {á }} \quad$ - az adott ágazatban foglalkoztatottak száma országosan,

E - az összes foglalkoztatottak száma országosan,

és így

$s_{i} \quad-$ az adott ágazatban foglalkoztatottaknak ekkora hányada dolgozik az $i$-edik területi egységben,

$x_{i} \quad-$ az összes foglalkoztatottaknak ekkora hányada dolgozik az $i$-edik területi egységben. 
Ez utóbbi értékek $-s_{i}$ és $x_{i}$ - nagyon fontosak lesznek a továbbiakban is, hiszen minden egyes mutatószám, amelyet alkalmazok, e két érték viszonyán alapul. Mind az $s_{i}=\frac{e_{i a ́}}{E_{a}}$, mind pedig az $x_{i}=\frac{e_{i}}{E}$ értékek összege 1 , tehát megoszlási viszonyszámokról van szó. Minden további (térbeli koncentrálódást vagy agglomerálódást mérő) mutatószám kiszámításakor e két érték különbségét vagy hányadosát fogom felhasználni.

Az LQ mutató 1-nél nagyobb értéke esetén a területi egységben az adott ágazatban az országoshoz viszonyítottan relatíve több foglalkoztatott található. Empirikus vizsgálataim során - figyelembe véve a térfelosztási szintet és a szakirodalomban szokásos határokat - én az LQ $\geq$ 1,5 értéket tekintettem választóvonalnak (Patik 2005, Patik-Deák 2005), tehát azokat a területi egységeket (kistérségeket) tekintettem az adott gazdasági tevékenységre specializálódottnak, amelyek 1,5 feletti LQ értékkel rendelkeztek.

A foglalkoztatási LQ-nak nagy szerepe van az alkalmazottak számában tükröződő térségi specializáció feltárásában. Habár az LQ mutató széles körben alkalmazott és népszerü, többek kritikáját kihívta azzal, hogy sokáig nem állt mögötte mélyebb elméleti és statisztikai háttér. Több kutató igyekezett megoldani a kérdést (O’Donoghue - Gleave 2004, Moineddin és társai 2003) standard normális eloszlásra visszavezetés és konfidencia intervallumok segítségével. A megfelelő gazdasági modellre alapozó hátteret Guimaraes és társai (2009) adtak, akik statisztikai tesztet dolgoztak ki a mutatószámhoz, tették ezt úgy, hogy igyekeztek az Ellison Glaeser $\gamma$ mutatóéhoz hasonló darts-tábla megközelítést alkalmazni (lásd 48. oldal).

Ratanawaraha és Polenske (2007, 47. o.) hiányosságként említi az LQ azon tulajdonságát, hogy mind az ágazati, mind pedig a területi aggregációs szint lényeges befolyással van az értékére. Így, ha például 3-jegyü ágazatfelosztási szinten vizsgálódunk, akkor az LQ területi értéke nem feltétlenül fogja kimutatni egy 4-jegyủ szintű (szakágazat) térbeli koncentrálódását. Ugyanígy a regionális szintű és szubregionális szintű elemzés más-más eredményt mutathat. Én nem tekinteném a mutatószám gyengéjének ezeket a tulajdonságokat, hiszen ez a probléma nem a mutatószámból magából, hanem az aggregálásból fakad. Sőt éppen e tulajdonság teszi lehetővé azt, hogy különböző aggregációs szinten elvégzett vizsgálatok összehasonlításával be lehessen azonosítani a térbeli koncentráció kiterjedését, illetve azt, hogy az irányába ható erők mely ágazatra specifikusak.

\section{Herfindahl index (Hirschman-Herfindahl-index - HHI)}

Az egy tevékenységi körben müködő vállalkozások létszámeloszlásának, az ágazati (nem térbeli) koncentrációnak mérésére szolgáló mutatószám a Hirschman-Herfindahl-index 
(Herfindahl 1950, Hirschman 1958, Ellison-Glaeser 1997). Ugyan nem térbeli koncentrációt mér, itt mégis megemlítem, mert egyrészt az EG $\gamma$ mutató kiszámításához szükséges, másrészt értéke fontos háttér-információt hordoz magában.

$$
H_{\text {ágazati }}=\sum_{k=1}^{N} z_{k}^{2},
$$

ahol

$N$ - az adott ágazatban működő vállalkozások száma,

$z_{k}-$ az adott ágazatban foglalkoztatottak $k$-adik vállalkozásra jutó hányada.

Különböző ágazatok Herfindahl-index értékei csak abban az esetben hasonlíthatók össze, ha azonos a két ágazatban működő vállalkozások száma. Ezért a mutató normalizált formuláját használjuk:

$$
H^{*}=\frac{H-\frac{1}{N}}{1-\frac{1}{N}}
$$

$H^{*}$ alacsony értéke ( 0 körül) az ágazat sok, kis létszámú vállalkozásba való elaprózódottságát jelenti, míg 1-hez közeli értéke az ágazat kevés vállalkozásba való tömörülését, koncentrációját jelzi. Az 1-es értéket pedig akkor veszi fel, amikor egyetlen vállalatba tömörül az egész ágazat. A Herfindahl-index értéke tehát arra enged következtetni, hogy az ágazatban foglalkoztatottak több kisebb vállalkozásban, vagy inkább kevesebb számú, de relatíve sok foglalkoztatottat alkalmazó vállalkozásban dolgoznak.

A Herfindahl index esetén nincs egyetértés abban, hogy abszolút vagy relatív mutatószám volna, mivel mindkét definíciónak részben megfelel (Tüü-né 1980). Kerékgyártó Györgyné (1980) általános koncentrációs mutatószámként kezeli.

A Herfindahl-index alapján az ágazatok a következő minősítő kategóriákba sorolhatók. Ha:

$$
\begin{array}{ll}
H^{*}<0,01 & \text { az ágazat erősen elaprózódott; } \\
0,01<H^{*}<0,1 & \text { az ágazat elaprózódott; } \\
0,1<H^{*}<0,18 & \text { az ágazat gyengén koncentrált; } \\
0,18^{13}<H^{*} & \text { az ágazat erősen koncentrált. }
\end{array}
$$

\footnotetext{
${ }^{13}$ Az Egyesült Államokban a monopolellenes törvényben ezt a határértéket, 0,18-ot határozták meg, efölött
} vizsgálatot indítanak az ágazatban, hogy jogellenesen müködik-e. 
Az előbbi esetben a Herfindahl-index a vizsgált ágazat vállalati létszámeloszlását mutatja, de nem csak ágazati koncentráció mérésére használható, hanem az ágazat térbeli eloszlásának meghatározására is. Ebben az esetben a megfigyelési egységek már nem az egyes vállalkozások, hanem a területi egységek. Ekkor így számítható a mutató értéke:

$$
H_{\text {térbeli }}=\sum_{i=1}^{M} s_{i}^{2},
$$

ahol $s_{i}$, és $M$ az $L Q$ index kiszámításánál már definiált értékek.

Térbeli koncentráció mérése esetén ennek a mutatónak előnye, hogy könnyen kiszámítható. Azonban nem hasonlíthatók össze az egyes ágazatok koncentráció tekintetében, hiszen a mutató kiszámítása nem homogén, nem egyenlő méretű területi egységeken történik (Bertinelli - Decrop 2005).

\section{Ellison-Glaeser koncentrációs index $(G)$}

Ez a jól ismert Gini-mutatóhoz hasonló, térbeli differenciáltságot jelző mérőszám a foglalkoztatottság eredeti térbeli eloszlásához hasonlítja az adott ágazatbeli foglalkoztatottság térbeli eloszlását (Ellison - Glaeser 1994).

$$
G=\frac{\sum_{i=1}^{M}\left(s_{i}-x_{i}\right)^{2}}{1-\sum_{i=1}^{M} x_{i}{ }^{2}}=\frac{\sum_{i=1}^{M} d_{i}{ }^{2}}{1-\sum_{i=1}^{M} x_{i}{ }^{2}}
$$

ahol

$$
\begin{array}{ll}
M & - \text { a vizsgált területi egységek száma, } \\
s_{i} \text { és } x_{i} & - \text { az LQ indexnél definiált értékek, } \\
d_{i}=s_{i}-x_{i} & - \text { a valós (adott ágazatbeli) és a várt (összes ágazatbeli) } \\
& \text { foglalkoztatotti hányadok különbsége az } i \text {-edik területi egységben, } \\
& \text { várható értéke } 0 .
\end{array}
$$

Az Ellison-Glaeser koncentrációs index $(G)$ alacsony értéke ( 0 körül) esetén az ágazatbeli foglalkoztatottság térbeli eloszlása hasonlít a foglalkoztatottság eredeti térbeli eloszlásához, míg magasabb értékei az ágazat nagyfokú koncentráltságát jelzik. Statisztikai értelemben véve relatív koncentrációs mutatónak nevezhető.

Alapvetően a nyers térbeli koncentráció (raw geographic concentration) mutatószáma, vagyis nem veszi figyelembe az ágazati eloszlást. Az G mutatóval szemben felmerült kritikák mégsem ennek a tulajdonságnak szólnak, hanem annak, hogy a priori definiálták, nem pedig a 
valószínűségi modell következményeként adódott, így a belöle származó EG $\gamma$ mutatónál statisztikai értelemben hatékonyabb becslés is létezik a két vállalat telephelyválasztása között fennálló korrelációra (Maurel - Sédillot 1999).

\section{Maurel és Sédillot $G_{A}$ mutatója}

Meg kell említenünk a G koncentrációs index egy módosított változatát is, amely kicsit más, de ugyanazon értékek kiszámítása szükséges hozzá, és emellett megtartja a G index elönyös tulajdonságait is (Maurel - Sédillot 1999).

$$
G_{A}=\frac{\sum_{i=1}^{M} s_{i}{ }^{2}-\sum_{i=1}^{M} x_{i}{ }^{2}}{1-\sum_{i=1}^{M} x_{i}{ }^{2}}
$$

E mutató ugyanúgy értelmezendő, mint a $\mathrm{G}$ index, alacsony értékénél az ágazatbeli foglalkoztatottság térbeli eloszlása hasonlít a foglalkoztatottság eredeti térbeli eloszlásához, míg 1-hez közeli értéke az ágazat nagyfokú koncentráltságát jelzi. Éppen úgy, mint a G mutató a nyers térbeli koncentráció (raw geographic concentration) mutatószámaként értelmezhető, és statisztikai értelemben relatív koncentrációs mutatószámként értelmezhető.

\section{Ellison-Glaeser $\gamma$ mutató}

A $G$ indexet célszerü módosítanunk az ágazati Herfindahl index értékének segítségével, mert - mint azt említettük - az csak a nyers térbeli koncentráció (raw geographic concentration) mutatószáma, és lényeges kérdés lehet, hogy miért koncentrálódik egy ágazat foglalkoztatottjainak nagy része egy (vagy néhány) területi egységbe. Vajon azért, mert csak kevés, esetleg egyetlen nagyvállalatból áll, vagy azért, mert sok kisebb vállalatból álló ágazatról van szó, amelyek mind azonos területi egységbe települtek?

Ez a módosított, az 1990-es években (Ellison-Glaeser 1994, 1997) publikált mutató annak az értéknek a becslése, amely megmutatja, hogy mekkora a korreláció két tetszőleges, az adott ágazatban működő vállalat telephelyválasztása között ${ }^{14}$.

Kiszámításához két fontos értéket használunk fel, a Herfindahl indexet $\left(H_{\text {agazati }}\right)$ és az Ellison-Glaeser koncentrációs indexet $(G)$. Az Ellison-Glaeser $\gamma$ index $(E G \gamma)$ képlete:

$$
\gamma=\frac{G-H}{1-H}
$$

${ }^{14}$ Legyen most $\mathrm{u}_{\mathrm{ji}}$ értéke 1 , ha a j-edik vállalat az i-edik területi egységbe települ, és legyen 0 egyébként. Ekkor $\gamma$ valójában becslése lesz a $\operatorname{Corr}\left(\mathrm{u}_{\mathrm{ji}}, \mathrm{u}_{\mathrm{ki}}\right)(\mathrm{j} \neq \mathrm{k}$, i tetszőleges $)$ korrelációsértéknek. 
Az EG $\gamma$ értékét a $[-1,1]$ intervallumban veheti fel. Negatív értéke az ágazat szétszóródottságát mutatja (a vállalatok telephelyválasztása ilyenkor nem véletlenszerü, sőt kifejezetten különböző területi egységekben igyekeznek letelepedni), pozitív értéke pedig már térbeli koncentráltságot jelez.

Statisztikai értelemben véve már inkább az általános jellegủ koncentrációs mutatószámok közé tartozik, mert vannak az abszolút és a relatív koncentrációs mutatókra jellemző tulajdonságai is.

Mivel az Ellison-Glaeser $\gamma$ mutató várható értéke 0, ez alapján az ágazatok az alábbi kategóriákba ${ }^{15}$ sorolhatók. Ha

$$
\begin{array}{ll}
\gamma<0 & \text { az ágazat térben szétszórt; } \\
0 \leq \gamma<0,02 & \text { az ágazat gyengén koncentrálódott; } \\
0,02 \leq \gamma<0,05 & \text { az ágazat közepesen koncentrálódott; } \\
0,05 \leq \gamma & \text { az ágazat erősen koncentrálódott. }
\end{array}
$$

A negatív értékek alapján is tovább lehetne differenciálni, de közgazdasági értelemben a pozitív értékek az „érdekesek”.

\section{Maurel és Sedillot $\gamma_{A}$ mutatója $\left(M S \gamma_{A}\right)$}

Ez a mutató az EG $\gamma$ mutatóval analóg módon számítható egyetlen különbséggel: az Ellison Glaeser koncentrációs index $(\mathrm{G})$ helyett Maurel és Sédillot $\mathrm{G}_{\mathrm{A}}$ mutatóját használjuk benne. A különbség valójában azon alapszik, hogy míg Ellison és Glaeser mutatójukban a két véletlenszerüen kiválasztott vállalat telephelyválasztásának korrelációját mérik, addig Maurel és Sédillot a $\gamma_{\mathrm{A}}$-val két véletlenszerüen kiválasztott munkás vállalatai telephelyválasztásának korrelációját mérik (Maurel - Sédillot 1999):

$$
\gamma_{A}=\frac{G_{A}-H}{1-H}
$$

Ennek a mutatónak az értelmezése is ugyanúgy történik, mint az EG $\gamma$ mutatóé.

15 Ezeket a határokat alkalmazta Ellison és Glaeser (1997), és a további, nemzetközi szakirodalomban megtalálható elemzések is ezt az osztályozást vették át. 


\section{Területi Gini együttható}

Krugman (1991b), miután feltette azt a kérdést, hogy miért koncentrálódnak térben a gazdasági tevékenységek, arra is megpróbált választ adni, egyáltalán hogyan mérhető ez a jelenség, miként lehetne összehasonlítani az egyes ágazatok koncentráltságát. Ezért megalkotta a területi Gini együttható fogalmát, amely a következőképp számolható:

$$
\text { Gini }=\frac{1}{M(M-1)} \frac{\sum_{\substack{i=1 \\ M}}^{M}\left|L Q_{i=1}-L Q_{j}\right|}{4 \overline{L Q}}=\frac{1}{M(M-1)} \frac{\sum_{\substack{i=1 \\ i \neq j}}^{M}\left|\frac{s_{i}}{x_{i}}-\frac{s_{j}}{x_{j}}\right|}{4 \frac{1}{M} \sum_{k=1}^{M} \frac{s_{k}}{x_{k}}}
$$

ahol

$$
\begin{array}{ll}
M & - \text { a vizsgált területi egységek száma, } \\
s_{i} \text { és } x_{i} & - \text { az LQ indexnél definiált értékek, } \\
\overline{\mathrm{LQ}} & - \text { az LQ értékek számtani átlaga. }
\end{array}
$$

Ez a mutatószám 0 és 0,5 között veheti fel értékét, a 0-hoz közeli értékek egyenletes eloszlást, az 0,5-hez közeliek pedig extrém koncentrációt jeleznek ${ }^{16}$.

Ennek a mutatószámnak egy nagy hátránya van az EG $\gamma$ mutatóval szemben, méghozzá az, hogy nem veszi figyelembe az egyes vállalatok méretét, azonban a két mutató értékeinek összehasonlítása fontos információt nyújthat az ágazat szerkezetéről.

Habár Kerékgyártóné (1980) megjegyzése szerint - mivel relatív koncentrációs mutató sohasem veheti fel a szélsőértéket - sem abszolút, sem relatív mutatószámnak nem tekinthető, én mégis relatív koncentrációs mutatószámnak tekintem, mivel egyenlőtlen eloszlást mér, miközben a sokasági egységek (jelen esetben területi egységek) számát teljesen figyelmen kívül hagyja, tehát abszolút mutatónak semmiképpen nem tekinthető.

Miután Krugman (1991b) megalkotta a területi Gini mutatót, több olyan tanulmány született, amely ezt a mutatószámot alkalmazta az egyes iparágak koncentrálódottságának mérésére.

Audretsch és Feldman (1996) kifejezetten az innovatív ágazatok, illetve a tudás túlcsordulás térbeliségének felmérését tủzték ki célul az USA-ban. A Gini mutatót alkalmazták, de nem csupán foglalkoztatottakra, hanem az ágazatbeli hozzáadott értékre és innovációkra is kiszámítva értékét. A területi egységek az USA tagállamai voltak, adataik 1982-re vonatkoztak.

16 A Gini együttható a Lorenz görbe és az átló által bezárt terület relatív nagyságát méri a fél négyzet területéhez képest. Krugman az egész négyzet területéhez képest mér és korrigál olyan módon, hogy a területi Gini egyuittható fel is veheti a 0,5-es értéket extrém térbeli koncentráció esetén. 
Ezután a kapott Gini értékeket, mint eredményváltozókat használták fel egy regressziós egyenletben, melyeknek magyarázó változói között szerepeltek: az iparág természeti erőforrásoktól való függése, a skálahozadék, az iparág szakképzett munkás-igénye, iparági K+F kiadások bevételegységre jutó hányada és az iparághoz kapcsolódó egyetemi kutatási kiadások.

Eredményeik szerint a természeti erőforrásoktól való szorosabb függés magasabb koncentrációt eredményez, a nagyobb skálahozadék viszont kifejezetten csökkenti a koncentrációt, nem pedig növeli. Mind a magasan képzett munkaerö-igény, mind pedig az iparági $\mathrm{K}+\mathrm{F}$ növekedése pozitívan befolyásolja koncentrációt, de az egyetemi $\mathrm{K}+\mathrm{F}$ nincs szignifikáns hatással rá.

Zitt és társai (1999) ugyancsak ezt a mutatószámot alkalmazták a tudományos technológiai tevékenységek térbeli koncentrálódásának mérésére. Adataik két időszakból, az 1988-90 közötti és az 1993-95 közötti évekből származtak, az akkori Európai Unió országos, NUTS-2 és NUTS-3 térfelosztási szintjeire vonatkoztak, és nem foglalkoztatottakra, hanem az ISI Science Citation Indexe és a Computer and Mathematics Citation Indexe alapján idézhető publikációkra, valamint európai szabadalmakra számolták ki, miközben ezt összevetették az egy före jutó GDP időbeli alakulásával. Az egyes Gini együttható értékeket kiszámolták mind a 15 tagországra mindkét regionális bontásban, majd az egész Európai Unióra is országos, NUTS-2 és NUTS-3 térfelosztási szinteken.

Eredményeik szerint a tudományos és technológiai tevékenységek térbeli eloszlása a várakozásoknak megfelelően sokkal koncentráltabb, mint a népességé vagy a gazdasági tevékenységeké. A koncentráció mind a szabadalmak, mind a tudományos publikációk esetében csökkenő tendenciát mutat, bár az előbbire sokkal nagyobb hatással vannak a nemzeti szintü politikai változások, mint az utóbbira. Mindenesetre a szük időintervallum kevés következtetés levonására alkalmas. A GDP és a szabadalmak koncentrációjának együttmozgása nagy országokban, míg a szabadalmak és a publikációk koncentrációjának együttmozgása kis országokban figyelhető meg.

Minden, eddig említett mutatószám esetében egy lényeges szempont kimarad a vizsgálatból, nevezetesen: egyik mutató sem érzékeny arra, hogy a területi egységek térben hol helyezkednek el egymáshoz képest (Arbia 2001). 


\subsection{Az agglomeráció mérése}

Mivel az ágazat agglomerálódása voltaképpen az ágazatnak a vizsgált területegységekben való eloszlásának térbeli autokorrelációját jelenti, a mérésének eszköze térstatisztikai, térökonometriai eszköz kell, hogy legyen ${ }^{17}$. Az autokorrelációs mérőszámok a gazdaság foglalkoztatotti létszám-alapú vizsgálatok esetében azt mutatják meg, hogy az $d_{i}=s_{i}-$ $x_{i}$ értékek (vagyis az adott ágazatbeli foglalkoztatottak területi egységre eső hányadának $\left(s_{i}\right)$ és a viszonyítási alapnak tekintett szektoriális, illetve össz-foglalkoztatottság területi egységre jutó hányadának $\left(x_{i}\right)$ különbsége) térbeli eloszlása utal-e valamiféle szabályszerüségre, vagyis a szomszédos területegységek adatai egymáshoz hasonlók-e (Varga 2002, Dusek 2004, Moran 1950).

Éppen úgy, ahogyan a térbeli koncentráció mérésénél, az agglomeráció esetében is megkülönböztethetünk globális és lokális mutatószámokat. Így amikor egy ágazatról egy mutatószámba sủrítve általános információ szükséges, akkor a globális térbeli autokorrelációs mutatókat használhatjuk (Moran index, Geary-féle C mutató), ha viszont az egyes területegységekről egyenként szeretnénk részletesebb képet kapni, akkor a lokális mutatók alkalmazása indokolt (LISA - lokális Moran-index, Lokális $G_{i}^{*}$ statisztika).

A térbeli súlymátrix, másképpen szomszédsági mátrix - amely alapján a következő mutatószámokban a térkapcsolatok megjelenítése megvalósul -, egy M x M-es mátrix, i-edik sorának j-edik eleme kifejezi az i-edik és a j-edik területi egység közötti térkapcsolat erősségét. Minél erősebb a kapcsolat, annál nagyobb a $w_{i j}$ érték. Megegyezés szerint $w_{i i}=0$. A térökonometriai szakirodalom bőséges lehetőséget kínál a szomszédsági mátrix kiválasztásához, legyen az a határszakaszokon, vagy távolságon alapuló (Dusek 2004, Anselin 1988), sőt tetszőleges előre adott lokális információk alapján elkészíthető a megfelelő szomszédsági mátrix (Getis - Aldstadt 2004).

\section{Moran index}

Moran által 1948-ban javasolt mérőszám azt mutatja, hogy az aktuálisan vizsgált adatértékek térbeli eloszlása utal-e valamiféle szabályszerüségre, vagyis a szomszédos területegységek adatai egymáshoz hasonlók-e (Moran 1950, Dusek 2004, Lafourcade-Mion

\footnotetext{
${ }^{17}$ A területi statisztika leírásáról lásd Dusek (2006)
} 
2007, Varga 2002). Amennyiben adataink a $d_{i}=s_{i}-x_{i}$ területi értékek ${ }^{18}$, akkor az ezek közötti területi autokorrelációs együtthatót kapjuk:

$$
\begin{aligned}
& I=\frac{M}{\sum_{i=1}^{M} \sum_{j=1}^{M} w_{i j}} \frac{\sum_{i=1}^{M} \sum_{j=1}^{M}\left(s_{i}-x_{i}\right) w_{i j}\left(s_{j}-x_{j}\right)}{\sum_{i=1}^{M}\left(s_{i}-x_{i}\right)^{2}}=\frac{M}{\sum_{i=1}^{M} \sum_{j=1}^{M} w_{i j}} \frac{\sum_{i=1}^{M} \sum_{j=1}^{M} d_{i} w_{i j} d_{j}}{\sum_{i=1}^{M} d_{i}^{2}}, \\
& \text { ahol } \\
& \mathrm{S}_{\mathrm{i}} \quad-\mathrm{az} \text { adott ágazatban foglalkoztatottaknak ekkora hányada dolgozik az } \\
& \text { i-edik területi egységben, } \\
& \mathrm{x}_{\mathrm{i}} \quad-\text { az összes foglalkoztatottaknak ekkora hányada dolgozik az i-edik } \\
& \text { területi egységben. } \\
& \text { M - a vizsgált területi egységek száma, } \\
& \mathrm{w}_{\mathrm{ij}} \quad-\text { tetszőleges szomszédsági mátrix i-edik sorának j-edik eleme. }
\end{aligned}
$$

A Moran index a $[-1 ; 1]$ intervallumban veheti fel az értékét.

$$
\begin{array}{ll}
I>\frac{-1}{M-1} & \text { esetén a térbeli autokorreláció pozitív; } \\
I=\frac{-1}{M-1} & \text { esetén nincs térbeli autokorreláció; } \\
I<\frac{-1}{M-1} & \text { esetén a térbeli autokorreláció negatív }{ }^{19} .
\end{array}
$$

Mivel a Moran index eloszlása nem ismert, ezért ebben az esetben nem lehet csupán az érték alapján megállapítani, hogy az ágazat térbeli eloszlása mennyire autokorrelált. Itt ugyanis különböző térfelosztási szintek mellett ugyanaz az I érték különböző szintü térbeli autokorrelációt jelezhet. Ugyanígy az alapadatok is befolyásolhatják az I értékek eloszlását. A térbeli autokorreláció megállapításához tehát szükség van a konkrét koncentrációs értékek felhasználásával, Monte-Carlo-módszer segítségével meghatározott (becsült) eloszlásra is. Így minden I érték esetén meghatározható egy p-érték, amely megmutatja, hogy a becsült eloszlás alapján az adott I érték a lehetséges esetek $(1-p) \cdot 100 \%$-ánál kisebb (negatív autokorreláció esetén), avagy nagyobb (pozitív autokorreláció esetén). A Luc Anselin által kifejlesztett GeoDa 0.9.5-i szoftver ${ }^{20}$ alkalmas e számítások elvégzésére, így segítségével megállapítható, hogy az illető ágazat térbeli eloszlása egy előre meghatározott szignifikancia szint - jelen esetben ez 5 százalék - mellett:

\footnotetext{
${ }^{18}$ Lehetne az LQ területi értékei közötti térbeli autokorrelációt is mérni - mint ahogyan azt tették Arbia és társai (2006) -, azonban ez félrevezető lehet, mert esetleg ott is jelentős agglomerálódást mutathat ki, ahol egy alacsony népességü területen egy néhány fös vállalat jelenik meg.

${ }^{19} 168$ kistérség esetén ez az érték -0,005988, 174 kistérség esetén pedig -0,005780.

${ }^{20}$ A szoftver ingyenesen letölthető a http://geodacenter.asu.edu/software/downloads címen.
} 
$I<-\frac{1}{M-1} \quad$ és a $p$ érték $<0,05$ akkor az ágazat erősen negatívan autokorrelált;

$I<-\frac{1}{M-1} \quad$ és $\quad 0,05<p$ érték $<0,1$, akkor az ágazat gyengén negatívan autokorrelált;

I bármilyen és 0,1 < p érték, akkor az ágazat nem autokorrelált;

$-\frac{1}{M-1}<I \quad$ és $\quad 0,05<p$ érték $<0,1$, akkor az ágazat gyengén pozitívan autokorrelált;

$-\frac{1}{M-1}<I \quad$ és a $p$ érték $<0,05$, akkor az ágazat erősen pozitívan autokorrelált.

\section{Geary-féle C mutató}

A Geary által 1954-ben publikált mutatószám a Moran-indextől abban tér el, hogy négyzetes különbségeken alapszik (Dusek 2004, Ping és társai 2004). Ugyanúgy, mint az elöbbi esetben, ha adataink az $d_{i}=s_{i}-x_{i}$ területi értékei, akkor az gazdaság agglomerálódásának területi autokorreláció alapú mérésére alkalmas. A korábbi jelölésekkel:

$$
c=\frac{M-1}{2 \sum_{i=1}^{M} \sum_{j=1}^{M} w_{i j}} \frac{\sum_{i=1}^{M} \sum_{j=1}^{M}\left(d_{i}-d_{j}\right)^{2} w_{i j}}{\sum_{i=1}^{M} d_{i}^{2}}
$$

ahol

$\mathrm{s}_{\mathrm{i}} \quad-\mathrm{az}$ adott ágazatban foglalkoztatottaknak ekkora hányada dolgozik az i-edik területi egységben,

$\mathrm{x}_{\mathrm{i}} \quad-\mathrm{az}$ összes foglalkoztatottaknak ekkora hányada dolgozik az i-edik területi egységben.

M - a vizsgált területi egységek száma,

$\mathrm{w}_{\mathrm{ij}} \quad-$ tetszőleges szomszédsági mátrix i-edik sorának j-edik eleme.

Ez a mutató a Moran index-szel ellentétben fordítottan értelmezendő (értékét a $[0 ; 2]$ intervallumban veheti fel):

$C<1$ esetén a térbeli autokorreláció pozitív;

$C=1$ esetén nincs térbeli autokorreláció;

$C>1$ esetén a térbeli autokorreláció negatív. 
Lokális Moran-index - LISA

Ez a mutató a Moran-index lokális változata, amely egy konkrét számértéket rendel minden egyes területi egységhez. Célja elsősorban az, hogy megtalálja azokat a területi egységeket, amelyekben a negatív, illetve pozitív autokorreláció szignifikánsan megjelenik. Cressie (1993) használta először a „hot spot” fogalmát, azon pontokat nevezve el így, amelyekben magas az aktivitási szint, vagyis olyan területi egységek, amelyekben, amelyek környezetében is magas a vizsgált érték. Ennek megfelelően „cold spot”-nak nevezhetjük azokat a területeket, amelyekben és környezetükben is alacsony a vizsgált adatérték. Ezt a mutatót Anselin (1995) definiálta, a Moran-indexnél használt jelölésekkel:

$$
I_{j}=M \frac{d_{i} \sum_{j=1}^{M} w_{i j} d_{j}}{\sum_{j=1}^{M} d_{j}{ }^{2}}
$$

A LISA index várható értéke 0, ezért ha ettől szignifikánsan eltérő értékeket kapunk $I_{i}$-re, vagyis a p-érték kisebb, mint 0,05 , akkor azt a következőképpen értékelhetjük: ${ }^{21}$

$d_{i}=s_{i}-x_{i}$ pozitív és $I_{i}$ is pozitív: HH (high-high) - Hot spot: a területi egységben és környékén sürübb az aktuális gazdasági tevékenység.

$d_{i}=s_{i}-x_{i}$ negatív és $I_{i}$ is negatív: LL (low-low) - Cold spot: a területi egységben és környékén ritkább az aktuális gazdasági tevékenység.

$d_{i}=s_{i}-x_{i}$ pozitív de $I_{i}$ negatív: HL (high-low), a területi egységben sürübb, környékén ritkább az aktuális gazdasági tevékenység.

$d_{i}=s_{i}-x_{i}$ negatív de $I_{i}$ pozitív: LH (low-high), a területi egységben ritkább, környékén sürübb az aktuális gazdasági tevékenység.

Amennyiben a szomszédsági mátrix sorstandardizált, vagyis $\sum_{j=1}^{M} w_{i j}=1$, akkor a lokális Moran-indexek összege a globális Moran-index $M$-szerese, vagyis $\sum_{i=1}^{M} I_{i}=M \cdot I$. (A GeoDa szoftver alkalmas ezen értékek kiszámítására és térképi ábrázolására is.)

\footnotetext{
${ }^{21}$ A 0-tól való szignifikáns eltérés ellenőrzése ugyancsak Monte-Carlo-módszerrel történhet, amit a GeoDa program elvégez. Az $I_{i} 0$-tól való szignifikáns eltérésének értelmezése ebben az esetben az eredeti adat (itt $d_{i}=s_{i}-$ $x_{i}$ ) standardizált értékéhez képest történik. 


\section{Lokális $G_{i}^{*}$ statisztika}

Ezt a mutatót Getis és Ord (1992) definiálta ugyanazzal a céllal, mint a lokális Moranindexet Anselin. A mutatószám tehát minden területi egységre egy számértéket ad:

$$
G_{i}^{*}=\frac{\sum_{j=1}^{M} w_{i j} d_{j}}{\sqrt{\frac{\sum_{j=1}^{M} d_{j}^{2}}{M}} \cdot \sqrt{\frac{M \sum_{j=1}^{M} w_{i j}^{2}-\left(\sum_{i=1}^{M} w_{i j}\right)^{2}}{M-1}}}
$$

A jelölések a már korábban alkalmazottak.

A számlálóban a $d_{j}$ értékeknek a szomszédsági mátrix $i$-edik sorában szereplő elemeivel súlyozott összege látható, a nevezőben lévő értékek pedig a standardizálást szolgálják. Ez a mutató is széles körben használt, előnye, hogy standard normális eloszlásúnak tekinthető (Getis-Ord 1996), ezért tetszőleges szomszédsági mátrix esetén a következőképpen értelmezhetö:

$$
\begin{array}{ll}
G_{i}^{*}>1,96 & \begin{array}{l}
\text { Hot spot: a területi egységben és környékén sürübb az aktuális } \\
\text { gazdasági tevékenység; }
\end{array} \\
-1,96<G_{i}^{*}<1,96 & \text { A 0-tól való eltérés nem szignifikáns; } \\
G_{i}^{*}<-1,96 & \text { Cold spot: a területi egységben és környékén ritkább az aktuális } \\
& \text { gazdasági tevékenység. }
\end{array}
$$

\subsection{A fejezet összegzése}

Ebben a fejezetben áttekintettem azokat a mutatószámokat, amelyek a legtöbbször alkalmazásra kerültek a gazdasági tevékenységek térbeli eloszlásának empirikus vizsgálatát célzó nemzetközi szakirodalomban.

A mutatószámok két szempont szerint osztályozhatók. Egyrészt, mint említettem, két fő irányban határozható meg az elemzések eszköztárának fejlődése is, tehát attól függően, hogy a gazdasági tevékenységek térbeli eloszlását független területi egységekbe való diszperzióként értelmezzük, vagy e területi egységek között térkapcsolatokat tételezünk fel, térbeli koncentráció, illetve agglomeráció mérése az eszközök célja. Másrészt lokális és globális mérőszámokat is megkülönböztethetünk: az első esetben a mutatószám minden területi egységre külön értéket ad, a második esetben a mutatószám a vizsgált iparágat az egész országra vonatkozóan jellemzi (1-2. táblázat). 
Az itt felsorolt mutatószámok közül én az EG $\gamma$ mutatót, a lokációs hányadost, a Moran indexet és a lokális Moran indexet használtam vizsgálataim során.

Azért választottam az EG $\gamma$ mutatót, mert alkalmazására és értelmezésére a szakirodalomban számos példát találtam, mint korrelációs mutatószám, számomra jól értelmezhető, és a Duranton és Overman (2005) által megfogalmazott, dolgozatomban később részletezett öt feltétel (lásd 48. o.) közül az első háromnak megfelel, a 4. feltételt pedig az agglomerációs mutatószámokkal együtt való értelmezés esetén teljesíti. Mivel lokális mutatószám alkalmazását is mindenképpen fontosnak tartom, ezért az LQ mutató alkalmazása kézenfekvőnek tünik.

Az agglomerációs méröszámok közül azért esett választásom a Moran indexre és a lokális Moran indexre, mert ezek együtt számolhatók és értelmezhetők, valamint alkalmazásukra a nemzetközi szakirodalomban is jóval több példát találtam, mint a másik két mutatószámra.

A következő fejezetben az 1. és 2. táblázatban felsorolt mutatószámok magyar és nemzetközi szakirodalomban való megjelenéseit és e vizsgálatok eredményeit összegzem, majd a kiválasztott mutatók alkalmazására a 4. fejezetben kerül sor. 
1. táblázat: A gazdasági tevékenységek térbeli koncentrációjának elemzésére szolgáló mutatószámok

Mutató

Képlet

Lokális mutató

LQ

$$
L Q_{i}=\frac{e_{i a ́} / E_{\text {á }}}{e_{i} / E}=\frac{s_{i}}{x_{i}}
$$

Globális mutatók

$$
\mathrm{H}_{\text {ágazati }}
$$$$
H_{\text {ágazati }}=\sum_{k=1}^{N} z_{k}^{2},
$$$$
\mathrm{H}_{\text {térbeli }}
$$

$$
H_{\text {térbeli }}=\sum_{i=1}^{M} s_{i}^{2}
$$

$$
G=\frac{\sum_{i=1}^{M}\left(s_{i}-x_{i}\right)^{2}}{1-\sum_{i=1}^{M} x_{i}^{2}}
$$

EG $\gamma$

$$
G_{A}=\frac{\sum_{i=1}^{M} s_{i}^{2}-\sum_{i=1}^{M} x_{i}^{2}}{1-\sum_{i=1}^{M} x_{i}^{2}}
$$

$\mathrm{MS} \gamma_{\mathrm{A}}$

$$
\gamma=\frac{G-H}{1-H}
$$

GINI $\quad$ Gini $=\frac{1}{M(M-1)} \frac{\sum_{i=1}^{M} \sum_{\substack{j=1 \\ i \neq j}}^{M}\left|L Q_{i}-L Q_{j}\right|}{4 \overline{L Q}}$

\section{Jelölések}

$\mathrm{e}_{\text {iá }}$ az i-edik területi egységben, az adott ágazatban foglalkoztatottak száma,

$e_{i}$ az i-edik területi egységben foglalkoztatottak száma,

Eá az adott ágazatban foglalkoztatottak száma országosan,

E az összes foglalkoztatottak száma országosan,

$\mathrm{s}_{\mathrm{i}}$ az adott ágazatban foglalkoztatottaknak ekkora hányada dolgozik az i-edik területi egységben,

$\mathrm{x}_{\mathrm{i}}$ az összes foglalkoztatottaknak ekkora hányada dolgozik az i-edik területi egységben.

$N$ az adott ágazatban múködő vállalkozások száma,

$z_{k}$ az adott ágazatban foglalkoztatottak $k$-adik vállalkozásra jutó hányada.

$s_{i}$ az adott ágazatban foglalkoztatottaknak ekkora hányada dolgozik az $i$-edik területi egységben,

$M$ a vizsgált területi egységek száma,

$d_{i}=s_{i}-x_{i}$ a valós (adott ágazatbeli) és a várt (összes ágazatbeli) foglalkoztatotti

hányadok különbsége az $i$-edik területi egységben, várható értéke 0.

$M$ a vizsgált területi egységek száma,

si és xi - az LQ indexnél definiált értékek.

Forrás: saját szerkesztés 
2. táblázat: A gazdasági tevékenységek agglomerációjának elemzésére szolgáló mutatószámok

\begin{tabular}{|c|c|c|c|}
\hline & Mutató & Képlet & Jelölések \\
\hline \multirow[t]{2}{*}{ Lokális mutatók } & LISA & $I_{j}=M \frac{d_{i} \sum_{j=1}^{M} w_{i j} d_{j}}{\sum_{j=1}^{M} d_{j}^{2}}$ & $\begin{array}{l}\mathrm{W}_{\mathrm{ij}} \text { tetszőleges szomszédsági mátrix i-edik sorának j-edik eleme. } \\
\mathrm{d}_{\mathrm{i}}=\mathrm{s}_{\mathrm{i}}-\mathrm{x}_{\mathrm{i}} \text { a valós (adott ágazatbeli) és a várt (összes ágazatbeli) foglalkoztatotti } \\
\text { hányadok különbsége az i-edik területi egységben, várható értéke } 0 \text {. }\end{array}$ \\
\hline & $G_{i}^{*}$ & $G_{i}^{*}=\frac{\sum_{j=1}^{M} w_{i j} d_{j}}{\sqrt{\frac{\sum_{j=1}^{M} d_{j}^{2}}{M}} \cdot \sqrt{\frac{M \sum_{j=1}^{M} w_{i j}^{2}-\left(\sum_{i=1}^{M} w_{i j}\right)^{2}}{M-1}}}$ & $\begin{array}{l}\mathrm{s}_{\mathrm{i}} \text { az adott ágazatban foglalkoztatottaknak ekkora hányada dolgozik az i-edik területi } \\
\text { egységben, }\end{array}$ \\
\hline \multirow[t]{2}{*}{ Globális mutatók } & Moran I & $I=\frac{M}{\sum_{i=1}^{M} \sum_{j=1}^{M} w_{i j}} \frac{\sum_{i=1}^{M} \sum_{j=1}^{M} d_{i} w_{i j} d_{j}}{\sum_{i=1}^{M} d_{i}^{2}}$ & $\begin{array}{l}\mathrm{x}_{\mathrm{i}} \text { az összes foglalkoztatottaknak ekkora hányada dolgozik az i-edik területi } \\
\text { egységben. }\end{array}$ \\
\hline & Geary's C & $C=\frac{M-1}{2 \sum_{i=1}^{M} \sum_{j=1}^{M} w_{i j}} \frac{\sum_{i=1}^{M} \sum_{j=1}^{M}\left(d_{i}-d_{j}\right)^{2} w_{i j}}{\sum_{i=1}^{M} d_{i}^{2}}$ & M a vizsgált területi egységek száma. \\
\hline
\end{tabular}

Forrás: saját szerkesztés 


\section{Az ágazatok térbeli koncentráltságának, illetve agglomeráltságának vizsgálatai: nemzetközi példák}

Az előző mutatószámok alkalmazására elsősorban a nemzetközi szakirodalomban találunk példákat. A lokációs hányados jelentette például az alapját a brit klaszterfeltérképezésnek (Miller és társai 2001), de már Magyarországon is megtörténtek az első, foglalkoztatási- $L Q$-ra épülő vizsgálatok az OECD-LEED klaszter-esettanulmányai keretében (Gecse - Nikodémus 2003). Regionális klaszterek LQ alapon történő vizsgálatával foglalkozott még Patik (2005), Patik és Deák (2005), valamint Szanyi és társai (2009). A lokációs hányadost használta Mukkala (2004) a finn feldolgozóipar vizsgálatára, melynek keretében az agglomerációs erők hatását elemezte területi LQ értékekre egy regressziós modell keretein belül.

Ellison és Glaeser (1997) a $\gamma$ mutatót az Egyesült Államok iparágainak vizsgálatára használták. Ezt követően sorban jelentek meg konkrét országok iparágainak koncentráltságát jellemezni kívánó elemzések. Amint az Ellison-Glaeser $\gamma$ mutató megjelent, napvilágot láttak különböző kritikák és módosítási lehetöségek. Maurel és Sédillot (1999) már saját módosított verziójukat (MS) használták, ahogy Alonso-Villar és társai (2004), illetve a DevereuxGriffith-Simpson (1999) szerzőhármas is ezt az MS-verziót alkalmazta számításai során. Franciaországra Maurel és Sédillot (1999), Nagy-Britanniára Devereux és társai (1999), Ausztriára Mayerhofer és Palme (2001), Belgiumra, Írországra és Portugáliára Barrios és társai (2009), Olaszországra Lafourcade és Mion (2007), Svédországra Braunerhjelm és Borgman (2004), Németországra vonatkozóan pedig Alecke és Untiedt (2008) végeztek EG $\gamma$ mutató alapú elemzéseket.

Az EG $\gamma$ mutató azonban nem csak egy iparág koncentráltságának mérésére ad lehetőséget, hanem az úgynevezett koagglomeráció mérésére is. Ez a fogalom több lehetőséget takar. Egyrészt mérhető két különböző iparág egymásra hatása, pl. egy iparág és az őt kiszolgáló iparágak közül a legnagyobb hányadot képviselő iparág között (Alonso-Villar és társai 2004) vagy egy szakágazat és az ezt tartalmazó ágazat között (Bertinelli - Decrop 2005). Másrészt iparágak egy csoportjának EG $\gamma$ mutatója felbontható a csoportot alkotó iparágakon belüli és azok közötti hatásra, ilyen módon elemezve az iparág-specifikus vonzóerők nagyságát (Alecke - Untiedt 2008). 
A tapasztalat azt mutatja, hogy az EG $\gamma$ mutató értéke erősen függ attól, milyen térfelosztási és iparág-felosztási szintet alkalmazunk, sőt a különbségek vizsgálata során fontos következtetésekre juthatunk. Ennek megfelelően többen végeztek robosztussági vizsgálatot az említett paraméterek megváltoztatása segítségével (Alecke - Untiedt 2008, Ellison - Glaeser 1997, Lafourcade - Mion 2007).

Több kutató igyekszik az EG $\gamma$ mutató értékeit regressziós egyenletben felhasználni. Egyes modellekben eredményváltozóként: idősoros modellben (Dumais - Ellison - Glaeser 1997, Barrios és társai 2005), iparágak technológiai színvonalával (Devereux és társai 2004, Alecke - Untiedt 2008), tudás-túlcsordulást, természeti adottságokat és szállítási költségeket reprezentáló változóval (Rosenthal - Strange 2001), vagy a vállalkozások méretével (Holmes - Stevens 2002, Lafourcade - Mion 2007), mint magyarázó változóval becsülve. Más modellekben pedig magyarázó változóként használták az EG $\gamma$ mutatót, például az egy foglalkoztatottra jutó hozzáadott érték becslésében (Braunerhjelm - Borgman 2004).

Több tanulmányban olvashatunk rangkorrelációs vizsgálatokról, többek között az EG $\gamma$ mutató és a Krugman által javasolt Gini együttható között (Braunerhjelm - Borgman 2004), az agglomerációs és koagglomerációs $\gamma$ értékek között (Devereux - társai, 1999, Alecke Untiedt 2008), MS $\gamma_{\mathrm{A}}$ együtthatója és EG $\gamma$ között (Maurel - Sédillot, 1999). Ezekből az elemzésekből kiolvasható, hogy az EG $\gamma$ mutatót befolyásoló tényezők hogyan és milyen intenzitással hatnak a mutató értékére.

Az agglomeráció mérésére leggyakrabban és legszélesebb körben a Moran indexet használják. Alkalmazása a gazdasági aktivitás sürüsödési helyeinek meghatározására csak az 1990-es évek végén kezdődött el, bár ezt a mutatót és módosított változatait ekkor már sokan és sokféleképpen használták. Moran 1950-ben publikálta, később Cliff és Ord (1973) értelmezési intervallumokat adott meg a Moran indexhez és a Geary-féle $c$ mutatóhoz is (Geary, 1954). A Moran indexet alkalmazták van Oort és Atzema (2004) a holland információ- és kommunikáció-technológia ipari és szolgáltató szektor agglomerációs vizsgálata során; Usai és Paci (2000) az innovációs tevékenységek térbeli eloszlásának elemzésére; Ying és társai (2005) a kínai Jiangsu tartományban az ipari tevékenységek agglomerálódásának felmérésekor, Lafourcade és Mion (2007) pedig az olasz foglalkoztatottsági adatokra. Ping és társai (2004) a texasi New Deal gyapotmezőinek hozamaira végeztek számításokat Moran index, Geary-féle C mutató és LISA index segítségével. Módszereik - ha nem is közvetlenül, de közvetve - alkalmazhatók a gazdasági tevékenységek vizsgálatára. 
A szakirodalomban e két irány - a független területi egységeké és a területi autokorrelációé - együttes alkalmazása és egy fogalmi keretbe helyezése először Sohn (2004) tanulmányában található. Lafourcade és Mion (2007) tanulmánya az agglomerációt és térbeli koncentrációt elsősorban a vállalkozások méretével összefüggésben tárgyalja. Később Carroll és társai (2008) az LQ-t és a Getis és Ord $G_{i}^{*}$ mutatóját, mint lokális mutatókat vetették össze, Nakamura és Morrison-Paul (2009) pedig már szoros összefüggésben tárgyalja e két módszert, alapos áttekintést adva.

Magyar adatokra többen is alkalmazták ezeket a mutatókat, a Moran indexet kistérségi szintü innovációs vizsgálatban Bajmócy és Szakálné (2009a, b, 2010b), ugyancsak kistérségi szinten feldolgozóipari alágazatokra a szerző (Szakálné 2011), valamint tudásintenzív feldolgozóipari és szolgáltatási ágazatokra a korábbi 168 kistérség és a TEÁOR'03 változata alapján (Szakálné 2008, 2009a, 2009b), 174 kistérség és a TEÁOR’08 változata alapján szintén a szerző alkalmazta (Szakálné 2010, 2012, Szakálné - Vas 2010). Koós (2007) cégsürüségi adatok alapján kifejezetten gazdasági tevékenységek térbeli sürüsödésére vonatkozó vizsgálatban használta a Moran indexet, Tóth (2003) pedig áttekintést nyújt a Moran index alkalmazásáról.

\subsection{Ellison-Glaeser $\gamma$ alapú térbeli koncentráció-mérések}

A térbeli koncentráció mérésének általam is alkalmazott módszerét Ellison és Glaeser 1994-ben publikálta. Céljuk az volt, hogy egy olyan mutatószámot alkossanak, amely elsősorban foglalkoztatottsági adatok alapján - megalapozott valószínüségi háttérrel számszerüsíti a vállalatok telephelyválasztásának térbeli összefüggéseit. Voltak korábban is a gazdasági aktivitás térbeli koncentráltságát mérő mutatószámok, azonban ezek elsődlegesen nem térbeli koncentráltsági mérőszámok alkalmazásai voltak (térbeli Gini mutató - Krugman 1991b, térbeli Herfindahl index). Ezekkel a korábban használt mutatószámokkal szemben az EG $\gamma$ mutatószám azonban számos előnnyel rendelkezik.

Mint korábban említettem, ez a mutató annak az értéknek a becslése, amely megmutatja, hogy mekkora a korreláció két tetszőleges, az adott ágazatban müködő vállalat telephelyválasztása között. Mindemellett teljesít 3 fontos feltételt, amely a vállalatok térbeli elhelyezkedését mérő mutatókkal szemben joggal támasztható (Duranton - Overman 2005). 
A mutatószám:

1. adjon lehetőséget a különböző ágazatok összehasonlítására;

2. az összes gazdasági tevékenység térbeli eloszlásának hatását szürje ki;

3. a térbeli koncentrációt tisztítsa meg az ágazati koncentrációtól.

Duranton és Overman (2005) további két feltételt fogalmazott meg, azonban ezeket csak korlátozottan, vagy egyáltalán nem teljesíti a mutatószám (Bertinelli - Decrop 2005):

4. torzítatlanság a térbeli felosztást tekintve;

5. meghatározható az értékek szignifikanciája.

A negyedik feltétel hiánya akár még előnyként is értelmezhető, amennyiben a különböző térfelosztási szintekhez tartozó mutatóértékek elemzéséből differenciáltabb következtetések levonására van lehetőség. Magyar példát tekintve, ha egy ágazat kistérségi szinten koncentrálódott, de megyei szinten nem, az azt jelenti, hogy azon kistérségek, amelyekben sűrübben előfordul az adott tevékenység, az országban szétszórtan helyezkednek el több megyében, és nem pedig az ország egy-két jól meghatározott megyéjében. Itt utalnék az úgy nevezett módositható területi egység problémájára (Modifiable Area Unit Problem MAUP), amely azt jelenti, hogy a választott területi egységek alakja, mérete és száma hatással van az elemzés eredményére, így általában ezek meghatározása nagy körültekintést igényel (Bertinelli - Decrop 2005; Dusek 2004; Lafourcade - Mion 2007). Ennek két következménye van, egyrészt a területi szint kiválasztása jelent gondot, másrészt pedig a térbeli autokorreláció, hiszen ez a mutató nem „„örödik” a területi egységek térbeli viszonyaival. Alecke és Untiedt (2008) kiemeli, hogy ha például egy olyan agglomerációs vonzóerőnek, mint a tudás túlcsordulásnak a hatósugara nagyobb, mint az adminisztratívan lehatárolt területi egységek átlagos sugara, akkor az EG $\gamma$ mutató a térbeli koncentráció valódi mértékét alulbecsli, ezért érdemes kiegészíteni térbeli autokorrelációs vizsgálattal is a $\gamma$ mutató alapján történő elemzést.

Az ötödik feltétel csak részben teljesül, mivel az EG $\gamma$ mutató eloszlása általában nem ismert. A nullhipotézis szerint a várható értéke nulla, vagyis azt feltételezzük, hogy a vállalatok random módon választanak területi egységet telephelyül, tehát mintha egy dartstáblára nyilat dobálva - azon tetszőleges eloszlást feltételezve ${ }^{22}$ - határoznák meg a telephelyük helyszínét. Ha meghatározható volna az eloszlás, akkor abból könnyen tudnánk konfidencia-intervallumot, illetve szignifikancia szintet számolni. Az eloszlás közelítésére

\footnotetext{
${ }^{22}$ Ahhoz, hogy a 2. feltétel teljesüljön, a feltételezett eloszlás a „darts táblán”, vagyis a vizsgált földrajzi terület térképén megegyezik az összes gazdasági tevékenység térbeli eloszlásával, amelynek hatását ki kívánjuk szürni.
} 
szokás Monte Carlo módszert alkalmazni, ez azonban számításigényes, így a szakirodalomban az Ellison és Glaeser (1997) által javasolt határok terjedtek el, amint arról az EG $\gamma$ bemutatásánál már szó esett ${ }^{23}$. E határok alkalmazása pedig összehasonlíthatóvá teszi az egyes vizsgálatok eredményeit.

\subsubsection{USA}

Ellison és Glaeser (1997) empirikus vizsgálatukat az USA 459 feldolgozóipari szakágazatára végezték el 1987-es adatokon mind megyei (county), mind tagállami, mind pedig makroregionális szinten. Ez az ágazati felosztás 4-jegyü SIC rendszerü osztályozás alapján történt. Mivel a mutatószám új volt a maga nemében, a szerzők kiszámították értékét többféle térfelosztási szint, és többféle ágazati osztályozási szint (tehát 2-, 3- és 4-jegyü SIC kódok) esetére is, annak érdekében, hogy összehasonlíthassák ezeket. Amit találtak, az módszertani és közgazdaságtani szempontból is jól magyarázható:

1. minél mélyebb az ágazati osztályozási szint, az EG $\gamma$ mutató értéke annál nagyobb;

2. a tagállami térfelosztási szint melletti $\gamma$ értékek átlagosan négyszer akkorák, mint a megyei szinten mértek; a tagállami és makroregionális szintek közötti különbség is hasonló, és úgy tünik, hogy a vállalatok egy makrorégióban való letelepedésének oka az esetek több mint felében az egy tagállamban való letelepedés.

Az első megállapításra a magyarázat az, hogy két azonos szakágazatbeli vállalkozás telephelyválasztása között szorosabb az összefüggés, mint ha a két vállalat csak azonos alágazatba vagy ágazatba tartozik.

Ellison és Glaeser, harmadik szerzőtársukkal, Dumais-vel (1997) a vállalatok telephelyválasztását és az iparágak szerkezetét egy folytonosan változó dinamikus folyamatként modellezték, amelynek része teljesen új vállalatok születése, a meglévő vállalatok zsugorodása, avagy bővülése, régi vállalatok térbeli terjeszkedése, avagy megszünése. Vizsgálatukat az 1972-től 1992-ig az USA-ban 5 évente felvett cenzus alapján végezték a tagállamok szintjén. Az EG $\gamma$ értékek időben egyre csökkenő tendenciát mutattak, az ágazati koncentráció (Hágazati értékek) viszont időben nem mutatott jelentős változást.

A dekoncentrálódás oka elsősorban az új vállalatok születése és a vállalatok terjeszkedése volt és ez fokozottan igaz a térben már korábban is koncentrált ágazatokra, a nagy természeti erőforrást igénylő és a high-tech ágazatokra. Az eredetileg térben kevéssé

\footnotetext{
${ }^{23} \gamma<0,02$ (alacsony térbeli koncentráció); 0,02 $<\gamma<0,05$ (közepes térbeli koncentráció) és $0,05<\gamma$ (erös térbeli koncentráció), lásd az EG $\gamma$ mutató leírásánál.
} 
koncentrálódott ágazatok térben még koncentráltabbakká is váltak, amely elsősorban telephelyváltásoknak köszönhető. Ezek után a szerzők megvizsgálták, hogy milyen tényezők játszanak szerepet abban, hogy a különböző iparágakhoz tartozó vállalatok egymás közelébe települnek. Azt találták, hogy sem a helyi beszállítók, illetve nagy helyi piac, sem a tudás túlcsordulás nem nagyon lényeges, bár szignifikáns hatással bírnak, a legfontosabb tényező azonban az azonos típusú munkaerő jelenléte volt.

Újabb vizsgálat látott napvilágot az USA feldolgozóiparának koncentráltságáról 2001ben ugyancsak az EG $\gamma$ mutató használatával. Rosenthal és Strange (2001) 2, 3 és 4-jegyü szinten vizsgálta az egyes ágazatokat tagállami, megyei és irányítószám (zipcode) szinten. Adataik 2000-ből származtak, és céljaik közt nem csak a térbeli koncentráció felmérése, de annak empirikus magyarázata is szerepelt.

Azt találták, hogy a 2-jegyü ágazatok esetében nincsen nagy különbség az egyes térfelosztási szintek esetében mért EG $\gamma$ értékek között, a korreláció közöttük minden esetben legalább 0,91. Az iparági felosztás mélyülésével viszont a különbségek nőnek, 4-jegyü ágazatok esetében a korrelációs együttható értéke 0,58 és 0,82 között mozog. Csak a $\gamma$ mutató értéke alapján három fontosabb következtetést tudtak a szerzők levonni a 4-jegyü ágazatok esetében. Vannak olyan ágazatok, amelyek csak a természeti adottságokból profitálnak (a cigaretta- és a szőrmeipar), további ágazatok koncentrálódásában az agglomerációs előnyök játszanak szerepet (a rakéta- és ürjármügyártás, valamint az irodai gép gyártása), végül pedig léteznek több térfelosztási szinten is erősen koncentrálódott ágazatok, azonban nem ez az általános kép, így tehát az egyes ágazatok esetében különböző típusú és hatósugarú folyamatok vezetnek koncentrációhoz.

Ezt követően regressziós modell segítségével felmérték az egyes feltételezett hatóerők, köztük a természeti adottságok, a szállítási költségek, a tényezö-megosztás (input sharing), a tudás túlcsordulás és a magasan képzett munkaerő jelenlétének hatását a területi koncentráltságra. Mindhárom térfelosztási szint mellett megbecsülték az egyes magyarázó változók hatását a 4-jegyü ágazatok EG $\gamma$ értékeire lineáris random modellek, majd pedig a lineáris fix hatású modellek segítségével (a fix hatások a 3-, illetve 2-jegyủ ágazatokhoz való hozzátartozást jelentették). Ez utóbbiak a 40\%-os magyarázóerőt érték el, viszont nehéz őket értelmezni.

Az első és legfontosabb eredményük az, hogy minden modellben egyértelmúen szignifikáns pozitív hatása volt a koncentrációra a munkaerőpiac koncentrált jelenléte. A random modellben a feldolgozóipari tényezők megosztása, mint koncentráló tényező csak tagállami térfelosztás mellett volt szignifikáns. A nem feldolgozóipari tényezők (pl. 
szolgáltatások) megosztása viszont kifejezetten negatív hatással bír a térbeli koncentrációra szinte minden modellben, és ez a hatás szignifikáns is a tagállami térfelosztási szint mellett. A tudás túlcsordulás - amelyet nagyvállalati innovációk jelenlétével mértek - hatása viszont ismét lényeges és pozitív, habár elsősorban térfelosztás zipcode-szintjén, és a hatás csökken, ha magasabb szintre lépünk - ez azt sugallja, hogy a tudás túlcsordulás térben viszonylag gyorsan lecseng. A természeti erőforrások koncentráló hatása ezzel szemben szignifikánsan csak tagállami térfelosztási szint mellett érvényesül, éppen úgy, ahogyan a feldolgozóipari tényezők megosztása, feltehetően a tagállami szintű szállítási eszközök fontossága miatt.

\subsubsection{Franciaország}

Ellison és Glaeser megalapozó munkája után Maurel és Sédillot (1999) használta fel eredményeiket, és rögtön javasolt is egy újabb mutatószámot, amelynek kiszámítása, ha kis mértékben is, de eltért az eredeti EG $\gamma$ mutatóétól. Amint említettem, e két francia szerző összehasonlította az EG $\gamma$, a saját $\gamma_{\mathrm{A}}$ mutatójuk és a térbeli Gini (Krugman 1991b) mutató alapján kiszámolt koncentrációs eredményeket. Elemzésükhöz 1993-as francia regionális és megyei (départements) adatokat használtak fel, és ugyancsak a feldolgozóipari ágazatokat vizsgálták 2-jegyü (50 db) és 4-jegyü ( $273 \mathrm{db}$ ) szinten.

A francia szerzők is ugyanazokat az osztályozási határokat használták, mint Ellison és Glaeser $(0,02 ; 0,05)$ ez alapján a vizsgált 4-jegyü ágazatok fele térben kicsit vagy egyáltalán nem koncentrált, a 4-jegyü ágazatok 27\%-a közepesen, 23\%-a pedig erősen koncentrált volt. A térben leginkább koncentráltnak a nyersanyagigényes nehézipari ágazatok bizonyultak, ezen kívül a hajóépítés, és a történelmileg kialakult regionális ipari specializáció eredményeképpen a pamut- és gyapjúgyártás, a cipő- és bőripar, valamint az óragyártás és játékgyártás ágazatok voltak erősebben koncentráltak. A ruhagyártás és könyvkiadás a párizsi központosulás miatt mutatkozott koncentráltnak, végül számos high-tech ágazat is ide tartozik.

A szerzők kihangsúlyozták a mutatószám statikus voltát, amelynek következtében a múltban lezajlott folyamatok eredménye tapasztalható a mutató értékében. A tradicionális iparágak magas térbeli koncentrációja lehet a történelmileg stabil környezeti hatások eredménye, ami akár már a visszájára is fordulhatott - vagyis a változások esetleg térben egyre szétszórtabb iparágakat eredményeznek -, miközben a high-tech iparágak magas térbeli koncentráltsága a ma is jelenlévő, erős, dinamikus tudás túlcsordulási hatás következménye. 
Az hogy a szerzők több ágazat-felosztási szintre is kiszámolták az EG $\gamma$ mutató értékét, lehetővé tette számukra, hogy ez alapján kiszámítsák a szakágazatok közötti koncentráció mértékét. A 2-jegyü ágazati EG $\gamma$ érték ugyanis kiszámítható az adott ágazatot alkotó 4-jegyü ágazatok EG $\gamma$ mutató értékeinek és egy másik $\gamma_{0}$ érték súlyozott átlagaként is. Maurel és Sedillot meghatározták azt a százalékos értéket, amekkora részét képezi a $\gamma_{0}$ az ágazati EG $\gamma$ értéknek.

Ez alapján megállapítható, hogy a nyersanyagigényes iparágak, mint a fémfeldolgozás szinte 100\%-ban a 2-jegyü ágazatokon belüli koncentráció miatt koncentráltak, sőt a $\gamma_{0}$ értéke még negatív is. Ezzel szemben több high-tech iparágban a 2-jegyü ágazat koncentráltága még magasabb is, és ezért a 4-jegyü ágazatok közötti koncentrációs hatások a felelösek (Jacobs externáliák), vagyis ezek a 4-jegyü ágazatok abból húznak hasznot, hogy más alágazatokkal azonos helyszínen telepszenek le, így a kutatásból származó tudástúlcsordulást, vagy a magasan képzett munkaerő jelenlétét használják ki. A nyomtatás és kiadói tevékenység is hasonlóan müködik, itt viszont a termék keletkezése egy folyamat, melynek egyes részeiért külön-külön 4-jegyü ágazatok felelnek. Itt pedig egyértelmủen az közbenső termékek kínálata és kereslete vezérli a koncentrálódást, ami a tevékenység-kompexitási elönyök kihasználására utal.

Ezen túl azt találták, hogy a high-tech feldolgozóipari ágazatok többnyire már szubregionális szinten is erős koncentrálódást mutatnak és ez a regionális szintre lépve is fennáll. Eredményeiket Ellison és Glaeser az USA-ra vonatkozó eredményeivel összevetve azt találták, hogy az ágazatok hasonló képet mutatnak, így azt a következtetést vonták le, hogy a technológiai tudás-túlcsordulás fontos szerepet játszhat a koncentrálódás kialakulásában.

A különböző térfelosztási szintekhez tartozó EG $\gamma$ értékek különbözőségét használta fel a szerzőpáros annak ellenőrzéséhez, hogy milyen hatóköre van az externáliáknak a 2-jegyü ágazatokban. Ehhez egy valószínüségi modell segítségével igazolták, hogy a megyei szintü EG $\gamma$ érték $\left(\gamma_{1}\right)$ a következő értékek súlyozott átlagaként áll elő minden ágazatra:

1. $\gamma_{0} \quad$ regionális térfelosztási szint melletti EG $\gamma$ érték az országra;

2. $\gamma_{\mathrm{i}}$ megyei térfelosztási szint melletti EG $\gamma$ értékek minden régióra különkülön;

3. $\gamma_{\mathrm{i}} \gamma_{0}$ keresztszorzatok.

Ezek alapján ismét százalékosan kifejezve ellenőrizhető az egyes összetevők hozzájárulása a megyei szintü EG $\gamma$ értékhez. Ez gyakran igen magas érték (akár túl is lépheti 
a 100\%-ot) tehát a koncentrációs erök ezekben az esetekben túllépnek a megyehatárokon, ilyenek a mindenhol koncentrálódott (például high-tech) ágazatok.

\subsubsection{Ausztria}

Mayerhofer és Palme (2001) egy nagy, az Európai Unió bővítését előkészítő projekt részeként vizsgálta az egyes osztrák feldolgozóipari és szolgáltatási ágazatok versenyképességét. Tanulmányuk keretében EG $\gamma$ mutató számítására is kitértek. Adataik 1995-ből származtak, a NACE 3-jegyü ágazat-felosztási és körzeti (Bezirk) térfelosztási szintre vonatkoztak. Az EG $\gamma$ mutató alapján osztályozták az ágazatokat, három csoportot hoztak létre mind az iparágak, mind a szolgáltatások körében:

1. tudásintenzív térben koncentrált alágazatok (12 ipari és 16 szolgáltatási);

2. nem tudásintenzív térben koncentrált alágazatok (26 ipari és 7 szolgáltatási);

3. térben nem koncentrált alágazatok (62 ipari és 46 szolgáltatási).

$\mathrm{Az}$ 1. csoportba tartozott néhány vegyipari alágazat, a gépgyártás egyes alágazatai, híradástechnika, szabályozó-, irányító- és mérőműszerek gyártása a szolgáltatások közül pedig olyanok, amelyek esetében sok a nem kodifikálható tudás, köztük a nagykereskedelem egyes alágazatai, az adatfeldolgozás, a K+F tevékenységek és a reklám. A 2. csoport elemei olyan iparágak, mint a fémfeldolgozás, a fafeldolgozás, a szerzők következtetései szerint ezek a természeti erőforrások miatt koncentráltak, míg a többi ilyen alágazat koncentráltsága történelmi okokra vezethető vissza. A szolgáltatások közül pedig a leglényegesebbek a turisztikai szolgáltatások, amelyek ugyancsak a természeti erőforrások miatt koncentráltak. A 3. csoportba tartozik az összes élelmiszeripari alágazat, mint ahogy az élvezeti cikkek gyártása is, valamint a foglalkoztatottak legnagyobb részét alkalmazó szolgáltatások: így a kiskereskedelem és a vendéglátó szolgáltatások.

\subsubsection{Svédország}

Braunerhjelm és Johansson (2003) svéd feldolgozóipari és szolgáltatási ágazatokra végzett elemzést. Az EG $\gamma$ mutató mellett Gini együttható számítást is végeztek, és vizsgálatuk két időpontra - 1975-re és 1993-ra - vonatkozott. Adataikat 4-jegyü ISIC ágazatfelosztási szintre vonatkozóan 70 régióra gyüjtötték, de 2-jegyü szinten is végeztek számításokat. 
Legfontosabb eredményeik a következők: a tudásintenzív iparágak között nagyon kevés az erősen koncentrálódott, de éppen így a leggyengébben koncentráltak között is csak kevés ilyet találni, inkább a középmezőnyben vannak a tudásintenzív ágazatok; az iparágak többségében erősödött a koncentráltság a két megvizsgált időpont között; a két mutató összehasonlítása is céljuk volt, azt találták, hogy a két mutató gyengén korrelál egymással.

Regressziós vizsgálatot is végeztek a feldolgozóipari ágazatokra, amelynek célja a MAR externáliák koncentráltságra való hatásának felmérése volt. Magyarázó változóik között szerepeltek a tudás-intenzitás, a belső méretgazdaságosság (átlagos vállalatmérettel mérve), a nyersanyag-igényesség, a szállítás költségessége és az iparág mérete. Két modell-típust teszteltek, egyikben az EG $\gamma$ mutató, illetve a térbeli Gini mutató értékét becsülték a magyarázó változókkal, a másikban pedig ugyanezen mutatók százalékos változását becsülték a magyarázó változók százalékos változásával.

Eredményeik szerint azon ágazatok, amelyekben a belső méretgazdaságosság érvényesül, térben koncentráltabbak, sőt Gini együttható becslésénél ez rendkívül magas szignifikanciájú érték ${ }^{24}$. A szerzők a pozitív hatást a munkapiaci hatásoknak tulajdonítják.

Magyarázóváltozóik között szerepelt az ágazatok tudásintenzitása is, melynek regressziós együtthatója ugyan pozitív volt mindhárom esetben, ezen együtthatók mégsem voltak szignifikánsak, tehát nem volt jele annak, hogy a tudásintenzív ágazatok jobban koncentrálódnának térben, mint más ágazatok. Habár megemlíthető, hogy eredményeik szerint a szolgáltatások esetében a tudásintenzív ágazatok nagyobb arányban szerepeltek a térben koncentráltabbak között, mint a feldolgozóipar esetén.

Éppen így a nyersanyag-igényesség és a szállítás költségessége sem mutatott szignifikáns összefüggést a térbeli koncentrációval, viszont kimutatták, hogy az iparág méretének növelése szignifikánsan csökkenti a koncentrációt. A szerzők egy útfüggőség mérésére alkalmas magyarázó változót, az 1975-ös EG $\gamma$ értéket is bevették a magyarázó változók közé, ez is erősen szignifikáns tényezőnek bizonyult.

A másik regressziós modell eredményei azt sugallják, hogy a térbeli koncentrálódás elsősorban nem a már meglévő vállalatok méretének megnövekedése útján történt, hanem új belépők, vagy pedig meglévő vállalatok áttelepülése révén.

24 Ez nem meglepő, hiszen ha a vállalatok átlagos mérete nagy, akkor ez, mint magasabb ágazati koncentrációt jelentő tényező maga is növeli a Gini együttható értékét. 


\subsubsection{Spanyolország}

Alonso-Villar és társai (2004) Spanyolország 17 regionális autonóm közösségére, valamint 50 provinciájára végeztek térbeli koncentrációs vizsgálatokat a feldolgozóiparra 2és 3-jegyű ágazat-felosztási szinten az 1993-1999 közötti periódusra. Ellison és Glaeser $\gamma$ mutatója mellett kiszámították a Maurel és Sédillot féle $\gamma$ becslést, ezen kívül a Gini együttható és a ágazati Herfindahl index értékeket is, és egyik céljuk ezek összehasonlítása volt. Arra az eredményre jutottak, hogy a mutatók nagyobbrészt hasonló sorrendbe rendezték az egyes 2-jegyü iparágakat. A vegyipar különböző besorolásából azonban arra a következtetésre jutottak, hogy az MS $\gamma_{\mathrm{A}}$ értéke olyan esetekben lesz nagyobb az EG $\gamma$-nál, amikor egy iparág egy egyébként is iparosodott területi egységben kicsit nagyobb arányban van jelen, mint az ipar általában - a vegyipar Barcelona és Madrid környezetében van jelen legnagyobb számban. A térfelosztás mélyebb szintjén a térbeli koncentráció alapjaiban nem változott, kivéve a közúti jármű gyártása ágazatot, amely úgy tünik, az autonóm közösségek szintjén egyenletesen oszlik el, azonban azokon belül a gyártás csak néhány provinciára összpontosul.

A dinamikus vizsgálat során a szerzők minden évre kiszámították az MS $\gamma$ értékét, és azt találták, hogy általános térbeli koncentrálódás következett be 1993-99 között, ez a számítógép, elektronikai, optikai termék gyártása és a bör és lábbeli gyártása ágazatok egyes autonóm közösségekben való helyi növekedése miatt igen nagyarányú volt.

Ez után a szerzők iparág-párokat vizsgáltak, mint alcsoportokat, annak érdekében, hogy meghatározzák az egyes ágazatok együttes viselkedését. Ehhez input-output táblázatokat használtak és az iparág és fó beszállitója, valamint iparág és fö felhasználója párokat alkottak. Sok esetben az iparág az önmaga legnagyobb beszállítója vagy felhasználója volt, ezekben az esetekben magas térbeli koncentráltságot találtak a cikk szerzői. A többi esetben a Maurel és Sédillot (1999) munkájánál már bemutatott $\gamma_{0}$ értékét számolták ki. Ez alapján a textilgyártás - ruházati termékgyártás párosa, valamint a papírgyártás - nyomdai tevékenység páros esetében volt magas az úgynevezett koagglomeráció. Az iparág és fő beszállítója párok közül az előbbi kettőn kívül még az orvosi müszergyártás, optikai termék gyártása, óragyártás - elektronikai és híradástechnikai termék gyártása ágazatpár és a müanyaggyártás - vegyipar páros rendelkezett nagyon magas $\gamma_{0}$ értékekkel.

A szerzők végül az OECD technológiai színvonal osztályozása alapján csoportosították az iparágakat 3-jegyü szinten, és kiszámították az egyes csoportok MS $\gamma_{\mathrm{A}}$ átlagait. A 3 jegyü ágazati felosztásban szereplő alágazatokat 4 csoportba sorolták: high-tech, intermediate-high- 
tech, low-intermediate-tech illetve low-tech alágazatokat határoztak meg. Összehasonlítva az egyes csoportok átlagos MS $\gamma_{\mathrm{A}}$ értékeit szignifikáns különbségeket találtak, a high-tech csoport kimagaslóan magas átlagos $\gamma$ értékkel rendelkezett a többi csoporthoz képest, tehát következtetésként levonható, hogy a magas tudásintenzitás magasabb térbeli koncentrálódást von maga után. Arra jutottak tehát, hogy a high-tech iparágak koncentráltsága kimagasló, főként a gyógyszergyártás rendelkezik nagyon magas $\gamma$ értékkel.

\subsubsection{Egyesült Királyság}

Devereux és társai (2004) is több évre vonatkozó (1985-92) vizsgálatot végeztek, adataik az Egyesült Királyság 211 darab 4-jegyű (SIC) ipari ágazatára, az irányítószám első két betűje alapján felosztott területekre vonatkoztak. A francia és az USA-beli vizsgálatok kimeneteleihez nagyon hasonló eredményeket kaptak, bár az Egyesült Királyságban kisebb térbeli koncentrációra utaltak az MS $\gamma_{\mathrm{A}}$ értékek.

Eredményeik szerint az olyan ágazatok a leginkább koncentráltak, amelyek természeti erőforrásokat igényelnek: ásványi anyag kitermelése és a halfeldolgozás, valamint olyanok, amelyekhez nagy mennyiségü helybéli munkaerő szükséges, ilyen például a textilipar. A legkevésbé koncentrálódott kétjegyü ágazatok között több high-tech iparág is van, ilyen az irodai gépgyártás és adatfeldolgozó müszerek gyártása, valamint az elektronikai és elektromos müszergyártás ágazatok. A szerzők ennek okát abban látták, hogy ezek az iparágak még újak és ezért még a koncentrálódási folyamat elején vannak. További korrelációs vizsgálatokból, amelyek a G, a H és a $\gamma$ értékek korrelációját elemezték a tőke/munka hányad, illetve a képzett munkaerő aránya értékekkel, az derült ki, hogy míg az előbbi pozitívan korrelál a G-vel, gyengén a H-val és nem korrelál a $\gamma$-val, addig az utóbbi pozitív korrelációt mutat a H-val és negatívat a $\gamma$-val. Ez azt jelenti, hogy a tudásintenzív ágazatok az Egyesült Királyságban inkább ágazatilag koncentrálódnak, és nem térben koncentrálódnak, tehát amíg a belső méretgazdaságosság lényeges, addig a külső elhanyagolható.

A szerzők koagglomerációs elemzést is végeztek Maurel és Sédillot (1999) által vázolt módszerrel, így meghatározták az egyes 2-jegyű ágazatokon belül, de a 4-jegyü iparágak között ható koncentrációs értéket. Azt találták, hogy a magas koagglomeráció egyúttal magas 2-jegyü ágazati koncentrációhoz is vezet.

Dumais és társai (1997) vizsgálatához hasonlóan a szerzők az iparágak szerkezetének dinamikus elemzését is elvégezték, és azt találták, hogy a túlélési arány magasabb, az új 
belépök aránya pedig alacsonyabb a térben leginkább koncentrálódott ágazatok esetében; bár néhány térben igen koncentrált ágazatban az új belépők még fokozták is a koncentrációt.

\subsubsection{Belgium, Írország, Portugália}

Bertnelli és Decrop (2005) Belgiumra végzett térbeli koncentrációra irányuló vizsgálatot. Cikkükben felvázolják azokat a lehetőségeket, amelyek a mérési módszerek alapján rendelkezésükre állnak, így egy átfogó képet mutatnak a mutatószámokról, azok előnyeiről és hátrányairól. Duranton és Overman (2005) mutatóját, amely az általuk megfogalmazott öt kritérium mindegyikének megfelel ${ }^{25}$, a belga kutatók az EG $\gamma$ mutatóval szemben háttérbe sorolják, mivel fontos szempontnak tekintik azt is, hogy a térbeli koncentrálódás forrását egyértelmúen hozzá lehessen rendelni egyes területi egységekhez, ami a döntéshozók dolgát is könnyebbé teszi. Ez a feltétel maradéktalanul teljesül az EG $\gamma$ mutató esetében, így a Belgiumra vonatkozó vizsgálatot ez alapján végezték el.

Adataik négy évre terjednek ki, 1997-2000-re, járások (43 területi egység) szintjére és a feldolgozóipar 4-jegyü (NACE) ágazat-felosztási szintjére vonatkoztak. A szerzők használhattak volna települési adatokat is, azonban a járások szintjét választották, mert el akarták kerülni a térbeli autokorreláció megjelenését. Barrios és társai (2009) ugyanezeket az adatokat felhasználva azt találták, hogy a lokális és regionális szintek térbeli koncentráltság értékei között igen erős kapcsolat van (a Spearman rangkorreláció értéke 0,7)

Bertnelli és Decrop eredményei - hasonlóan a korábban megjelent USA-beli, francia, illetve Egyesült Királyságbeli eredményekhez - az olyan ágazatokban mutattak erős térbeli koncentrálódást, amelyek természeti erőforrás függők, például a kőolaj-feldolgozás, valamint a történelmi okok miatt máshol is koncentrálódott textilipar. Az OECD (1997) által high-tech, illetve medium-high-tech iparágnak definiált ágazatok is több esetben erősen koncentráltnak nevezhetők, azonban a szerzők ezt nem kizárólag az 4-jegyü iparágon belüli tudástúlcsordulás számlájára írják, hanem más, térben koncentrált, tradicionálisabb iparággal való szoros kapcsolat eredményének. Továbbá a belga szerzők is kiemelik, hogy a high-tech iparágak vizsgálata dinamikusabb megközelítést igényelne, mivel ezek az ágazatok leginkább újak, így sok szerkezeti változás következhet még esetükben.

A szerzők megvizsgálták a koagglomeráció mértékét is az egyes 2-jegyű ágazatokon belüli összefüggések feltárása érdekében. Azt találták, hogy a térbeli koncentrálódást

\footnotetext{
${ }^{25}$ Ez egy folytonos, az egyes vállalkozások pontos helyének meghatározásán és távolságszámításon alapuló mérőszám, amelynek bemutatásától jelen tanulmány keretein belül eltekintünk.
} 
elősegítő erők elsősorban a 4-jegyü ágazatokon belül hatnak, az ágazatok között ez kevésbé érvényesül, van azonban négy olyan ágazat, ahol a koagglomeráció kimagaslóan nagy értékü: a textilipar, a ruha-és szőrmegyártás, a nyomdai és sokszorositási tevékenységek, valamint a müszergyártás. Ezekben az esetekben a szerzők az urbanizációs előnyök jelenlétét (Jacobs externáliák) tartják a térbeli koncentráció elsődleges forrásának, míg a koagglomeráció alacsonyabb értékei esetén a szerzők szerint a lokalizációs előnyök hatása érvényesül.

A belga szerzők cikkükben előálltak egy új gondolattal, melynek során minden iparágat két részre bontottak: a 20 fönél többet és a legfeljebb 20 föt foglalkoztató vállalatok csoportjaira, majd ezekre külön-külön is kiszámították az EG $\gamma$ értékeket. Tették ezt azért, mert a kisebb vállalatok többnyire kiszolgáló funkciót látnak el, így szétszórtak, vagy pedig éppen a nem specializálódott területi egységekben való elhelyezkedésük miatt kicsik maradtak, tehát a szerzők várakozása szerint a nagyvállalatok térben koncentráltabban jelennek meg. Azt találták, hogy a nagyobb vállalatok térbeli koncentráltsága az EG $\gamma$ értékben kifejezve valóban 60-80\%-kal magasabb, mint a kisebb vállalatoké, azonban a Spearman rangkorrelációs vizsgálat szerint a kis-, illetve a nagyvállalatokra kiszámított EG $\gamma$ érték-sorrendek között kevés, habár pozitív irányú kapcsolat van.

Kiszámították a Moran index értékeket is, és - habár nem közöltek részletes adatokat róla - azt mutatták ki, hogy települési szinten az iparágak 35\%-a szignifikánsan (p-érték < $0,1)$ pozitív autokorrelációt mutat.

Amint említettem Barrios és társai (2003, 2009) ugyanezeket az adatokat használták fel további elemzés alapjaként Írország, Belgium és Portugália összehasonlítására. A vizsgálatuk alapján még kiemelték a térben legkevésbé koncentrálódott iparágakat, amelyek elsősorban Belgiumban és Portugáliában, kisebb mértékben viszont Írországban is szétszórtan helyezkednek el a térben. Ezek föként az élelmiszeripar és italgyártás egyes részei, köztük a húsfeldolgozás és a malomipar voltak, tekintve, hogy termékeik romlandóak.

Barrios és társai (2005) egy másik vizsgálatban Írország és Portugália feldolgozóipari ágazataira végeztek EG $\gamma$ alapú vizsgálatot az 1985-98 közötti évekre. A két ország összehasonlítására azért vállalkoztak, mert a vizsgált időszakban mindkét ország gyors strukturális változásokon ment keresztül, melynek során felzárkóztak az EU többi országa mellé.

A portugál adatok 85 iparágra terjedtek ki 4-jegyủ ágazat-felosztási szinten (ISIC kód), és mindösszesen 18 szárazföldi körzetre vonatkoztak, ami NUTS2 és NUTS3 közötti térfelosztási szintnek felel meg. Az írországi adatok 67 iparágat fedtek le ugyanúgy 4-jegyü 
ágazat-felosztási szinten (ISIC kód), és 27 megyére vonatkoztak, amelyek viszont a mai NUTS 3 és LAU 1 szint között helyezkednek el.

A szerzők azt találták, hogy az EG $\gamma$ értéke, vagyis a térbeli koncentráció, átlagosan mindkét országban csökkent, azonban míg ez Portugáliában fokozatosan történt a vizsgált 13 év alatt, addig Írországban a csökkenés nagyobb arányú volt, és sokkal gyorsabban, 1990-94 között ment végbe. A szerzők ezen túl arra voltak kíváncsiak, hogy milyen okok következtében mentek végbe ezek a változások. Ennek érdekében egy idősoros regressziós modellt állítottak fel Dumais és társai (1997) módszere alapján. Azt találták, hogy mindkét országban nagy volt a feldolgozóiparban a vállalatok mobilitása, miközben ehhez képest csak kevéssé változott az egyes ágazatok koncentráltsága. A diszperziót elősegítő tényezők közül a legfontosabb mégis leginkább az új vállalkozások megjelenése, hiszen ezek mindkét országban távol települtek az ágazati centrumoktól. Ezen kívül a high-tech iparágak esetében is szóródás volt tapasztalható a vizsgált években, amely jelenségre ugyancsak a térfelosztási szint adhat magyarázatot. Barrios és társai (2009) újabb, e három országot összehasonlító tanulmányában mind Írország, mind Belgium és Portugália esetében ugyancsak a high-tech iparágak térbeli szétszórtságát észlelték, és ennek okait a térfelosztási szint alkalmatlansága mellett az ágazat-felosztási szint túlzott mélységében találták meg a szerzők.

A három ország összehasonlítása során Barrios és társai az EG $\gamma$ mutató eloszlásáról is egy lényeges megfigyelést tettek. Ellison és Glaeser olyan határokat használt $(0,02$ és 0,05$)$ az ágazatok osztályba sorolásához, amelyek nem a mutató eloszlásából származnak, habár megadták a mutató szórását is, emiatt más következtetésre juthat a megfigyelö, ha a szokásos módon határnak a szóródás kétszeresét választja. A variancia nagysága ugyanis együtt nő a mutatóban szereplő ágazati koncentrációt mérő Hirschman-Herfindahl index nagyságával. mivel a kisebb országok ágazatai többnyire kevesebb vállalatból állnak, az ágazati koncentráció értéke magasabb, így az EG $\gamma$ mutató szórása is nagyobb, tehát a kisebb országok esetében a térbeli koncentráció kevesebb esetben fogja túllépni a szórás kétszeresét. Ezt a szabályt alkalmazva az írországi EG $\gamma$ értékek közül 25\%, a belga értékek közül 49\%, a portugál értékek közül pedig $75 \%$ mutatott szignifikáns térbeli koncentrációt 4-jegyü ágazatok esetében, ami alátámasztani látszik Barrios és társai megfigyelését.

Ezen túl a szerzők mindhárom országra lineáris regressziós modellben becsülték az EG $\gamma$ értékeket 4-jegyủ ágazat-felosztási szinten. A magyarázó változók között szerepeltek inputköltségek javakra és szolgáltatásokra, magasan képzett dolgozók aránya az iparágban, belső kutatás-fejlesztési kiadások, energia költségek, tárgyi javakba való befektetések, befektetések müszerekbe és gépekbe, valamint átlagos vállalatméret, ezen kívül 2-jegyü ágazati dummy 
változókat is alkalmaztak. Mindezeket az iparágakban foglalkoztatottak számával súlyozva vették figyelembe a regressziós modellekben.

Írország esetében a modell rendkívül alacsony magyarázóerővel rendelkezett és a kontrollváltozók sem voltak szignifikánsak. Belgium esetében $24 \%$-os volt a magyarázóerő és egyetlen változó, az input-költségek javakra és szolgáltatásokra volt szignifikáns pozitív hatással a térbeli koncentrációra. Portugália esetében $25 \%$-os volt a magyarázóerő, és mind az input-költségek javakra és szolgáltatásokra, mind a magasan képzett dolgozók aránya az iparágban, és a belső kutatás-fejlesztési kiadások szignifikáns pozitív hatását mutatta ki a modell. A Belgiumra és Portugáliára vonatkozó eredmények alapján elsődlegesen a helyi input-piac van hatással a térbeli koncentrációra, ahogyan ezt sok más tanulmányban is kimutatták.

Regressziós eredményeiket a szerzők felhasználták arra is, hogy megvizsgálják, az egyes ország-párok esetében mi az oka az EG $\gamma$ mutatók átlagai közötti eltéréseknek, ehhez pedig Oaxaca (1973) módszerét alkalmazták:

$$
\bar{\gamma}_{i}-\bar{\gamma}_{j}=\left(\beta_{i}-\beta_{j}\right) \bar{X}_{i}+\beta_{j}\left(\bar{X}_{i}-\bar{X}_{j}\right)
$$

E módszer alapján megállapítható, hogy az eltérés az eredményváltozók átlagai között a magyarázóváltozók országonként eltérő hatásának, vagy pedig a magyarázóváltozók közötti számszerü eltérésnek köszönhető. Ez alapján az ország-párok különbözőképpen viselkedtek, amiből a szerzők azt a következtetést vonták le, hogy elővigyázatosság szükséges, ha két ország gazdaságának térbeli eloszlását hasonlítjuk össze, mivel több olyan ország-specifikus tényező lehet, amely az eredményeket befolyásolja.

\subsubsection{Németország}

Alecke és Untiedt (2008) Németországra végzett térbeli koncentrációs elemzést. Adataik 213 feldolgozóipari és szolgáltatási ágazatra terjedtek ki 3-jegyű (NACE) ágazatfelosztási szinten, és 439 körzetre (NUTS 3-as szint), valamint az ezekből alkotott 97 térségfejlesztési régiókra az 1998-as évben.

Alapvetően a 3-jegyü ágazat-felosztási szinten végezték a vizsgálatot, amelynek eredményeképpen a térben leginkább koncentrálódott ágazatok között a bányászat alágazatait, a tengeri szállítást, a légi szállítást és a halfeldolgozást találjuk, ami ezen ágazatok természeti erőforrás-, illetve infrastruktúraigényét tekintve nem meglepő. Azonban három szolgáltatási alágazat is szerepel itt, a hitelezési tevékenységek, a humán kutatás, fejlesztés, és a pénzügyi 
kiegészítő tevékenységek. Ezen alágazatok esetében viszont a szolgáltatást nyújtó és a vevő közötti közvetlen térbeli kapcsolat nem szükséges, vagy pedig a szolgáltatást nyújtó személy mobilitása által áthidalható.

Az Ellison-Glaeser $\gamma$ mutató alapján dolgoztak, azt regressziós modellben eredményváltozóként becsülve különböző dummy-változók segítségével, melyek közt szerepeltek az ágazatok tudásintenzitására vonatkozó változók is.

A szerzők nem találtak bizonyítékot arra, hogy a high-tech iparágak térben koncentráltabbak volnának, helyettük inkább tradicionális iparágakat találtak az első 20 ágazat között: az óragyártás, az ékszergyártás, a kerámiacsempe, lap gyártása és a kötött, hurkolt kelme gyártása alágazatok ilyenek. A lista másik végén elsősorban szolgáltatások találhatóak, de itt is van néhány meglepő alágazat, köztük a kerékpár, motorkerékpár gyártása, az adatbázis tevékenység és a villamos motor, áramfejlesztö gyártása alágazatok, amelyek térbeli szétszórtságáért a magas ágazati koncentrációt találták felelősnek a szerzők, ugyanis ezen ágazatokban kevés, de annál nagyobb vállalat van, amelyek azonban különböző területi egységekben müködnek.

A német szerzők ugyancsak végeztek koagglomerációs vizsgálatot a Maurel és Sédillot (1999) cikkében leírt módon. Felmérték az egyes 2-jegyű ágazatok térbeli koncentráltságát, és azt, hogy ennek mekkora hányada ered alágazatokon belüli, illetve alágazatok közötti koncentrációból. A legtöbb olyan ágazat, amelyben a térbeli koncentráció nagy része alágazatok közötti koncentrációból származik, általában a térben legkevésbé koncentrált ágazatok közül került ki. Ezek közül a közúti jármü gyártása szerepel az első helyen, ami arra utal, hogy egymást kiszolgáló alágazatok vállalatai települnek közel egymáshoz, miközben az azonos alágazatba tartozó vállalatok távolabb helyezkednek el egymástól.

Az előbbi elemzéseken túl, amelyek eseti magyarázatot adtak a vizsgált ágazatok térbeli koncentráltságára, a szerzők regressziós elemzést is végeztek, amely valamilyen összefogó magyarázattal szolgálhat a térbeli koncentráció okaira. Ennek érdekében többféle módon is osztályokba sorolták mind az egyes ipari, mind a szolgáltatási alágazatokat, és ezeket dummy változókban jelenítették meg az egyes becsült modellekben. Konstans értékek nem szerepeltek a modellekben, így a becsült együtthatók az átlagos EG $\gamma$ értéket jelenítik meg az adott csoportra.

Az első beosztás alapján erősen szignifikánsan koncentrált térben a bányászat, valamint a standard technológiai színvonallal rendelkező feldolgozóipari alágazatok csoportja, és mind a szolgáltatások, mind a feldolgozóipar esetében magasabb volt a nem tudásintenzív ágazatok átlagos EG $\gamma$ értéke, mint a tudásintenzíveké. 
A másik osztályozás szerinti eredmények arra engednek következtetni, hogy a bérintenzív feldolgozóipari alágazatok magasabb és szignifikáns térbeli koncentrációt mutatnak, szemben a tőkeintenzívekkel, míg a szolgáltatások esetében a nagyobbrészt vállalatoknak szolgáltató alágazatok voltak térben koncentráltabbak a személyi szolgáltatásokat nyújtó alágazatokhoz mérten.

\subsection{Moran index alkalmazások}

A Moran index is sok esetben került már alkalmazásra gazdasági tevékenységek térbeli eloszlásának vizsgálata során, azonban nem csak ezt, hanem a tudás túlcsordulás területi tulajdonságait is sok tanulmányban elemezték segítségével.

Breschi (1998) az Európai Szabadalmi Hivatalhoz olaszországi vállalatok által benyújtott szabadalmi bejelentések térbeliségét vizsgálta Olaszországban NUTS-3 szinten (provinciák). Adatai az 1987 és 1994 közötti évekböl származtak, és 30 technológiai alterületbe sorolhatók. Ezen túl magyarázó változóként $K+F$ kiadások, innovatív tőkejavakba való befektetések, vállalatok és foglalkoztatottak száma NACE 3-jegyü szinten, a népesség nagysága, valamint az agglomerációs hozadékot mérö üzleti telefonszámok száma és a torlódási költségek, az utak zsúfoltsága alapján gyüjtött adatokat ugyanezen alterületekre.

Elöször a szabadalmi bejelentések, a foglalkoztatottak, a vállalkozások és a népesség térbeli koncentrációját vizsgálta mindegyik technológiai alterület esetére az úgynevezett Herfindahl ekvivalens mutató (a Herfindahl index reciproka) segítségével. További vizsgálatokat végzett arra vonatkozólag, hogy ez a koncentráltság milyen struktúrával rendelkezik (külön elnevezést a két fogalomra nem használt, de nála is az a gondolat jelenik meg, ami sok más kutató esetében: érdemes a nagy koncentrációval rendelkező területek egymáshoz való térbeli viszonyát is felmérni). Ennek megfelelően a Moran indexet használta az egyes technológiai alterületekhez tartozó szabadalmi bejelentések abszolút számának, szabadalmi bejelentések egy foglalkoztatottra jutó számának, szabadalmi bejelentések egy tőkeegységre jutó számának, és a foglalkoztatottak számának térbeli autokorrelációjának mérésére.

Megállapította, hogy mind az innovatív, mind a feldolgozóipari tevékenység jóval erősebben koncentrálódott térben, mint maga a népesség, az innovatív tevékenységek (vagyis a szabadalmi bejelentések) pedig erősebben koncentrálódnak, mint általában a feldolgozóipariak. A térbeli koncentráltságot általában magasnak találta a legtöbb elektromos- 
elektronikus müszergyártó, és a vegyi-gyógyszeripari ágazatok esetében, míg alacsonynak a legtöbb mechanikus, ipari gépgyártó ágazatoknál. A térbeli autokorreláció vizsgálata során viszont éppen fordított képet talált: elsősorban a kevésbé innovatív, és a kevésbé koncentrálódó ágazatokat találta térben szignifikánsan pozitívan autokorreláltnak, miközben az az innovatív tevékenységek és az elektromos-elektronikus műszergyártó, és a vegyigyógyszeripari ágazatok inkább szigetszerủen jelentek meg egy-egy provinciában.

Ezt követően a szerző elvégzett egy regressziós becslést annak megállapítására, hogy milyen hatással van az innovativitásra az agglomerációs hozadék, a tudás túlcsordulás, a változatos helyi tudásbázis, az adott provinciának egyes olasz területekhez való hovatartozása, a zsúfoltság és a helyi átlagos hozzáadott érték. A becslését zéró inflált Poisson modell alapján végezte. Eredményei szerint mind az agglomerációs hozadéknak, mind a tudás túlcsordulásnak egyértelmüen pozitív hatása van a provinciák innovatív teljesítményére, ahogyan a változatos helyi tudásbázisnak is. Ezzel szemben a zsúfoltság és az innovatív tőkejavakba való befektetések negatív hatással bírnak az innovatív teljesítményre, minthogy ez utóbbi inkább egy passzív tevékenységnek fogható fel (tudás-alkalmazás) szemben a szabadalmi tevékenységekkel (tudásteremtés).

Bonaccorsi és társai $(2005,2006)$ két különböző megközelítésben is vizsgálták a tudás túlcsordulást. Első tanulmányukban egy speciális esetet vizsgáltak (Bonaccorsi és társai 2005): az infokommunikációs technológiák (IKT) térbeli terjedését. Ezt térbeli autokorreláció (Moran index) mérésével, domain nevek alapján elemezték 103 olasz provinciára (NUTS3 szint), valamint regressziós modell segítségével mérték fel a befogadókészség, a verseny, a vállalatok átlagos nagysága, az ágazati összetétel, technológiai ellátottság hatását az ICT terjedésére. Azt találták, hogy van térbeli autokorreláció, és elsősorban a közép-észak olaszországi értékek voltak magasak, a dél-olasz területeké pedig alacsonyak, a központi provinciáktól a periféria felé haladva egyre csökken az IKT alkalmazás.

A regressziós eredmények alapján a befogadókészség, a verseny, a vállalatok átlagos nagysága, a technológiai ellátottság szignifikánsan pozitív hatással van az IKT alkalmazásra, az ágazati összetétel viszont nem szignifikáns. Ezen túl alkalmaztak térökonometriai regressziós modellt is, amelynek eredményei szerint nem csak a provincia saját magyarázó változó értékeinek befolyásoló hatása érvényesül, hanem a szomszédos provinciák adatai is szignifikáns hatással bírnak az IKT alkalmazásra.

Moreno és társai (2005) az innovációs tevékenység térbeli eloszlását vizsgálták európai szabadalmi adatok segítségével két időszakra: 1994-96 között és 1999-2001 között. A szabadalmi aktivitást Európa 17 országára elemezték regionális szinten (175 régió), az 
iparágak szerint pedig ISIC 2 jegyü szintig voltak bontva adataik (23 feldolgozóipari ágazat). Céljuk egyrészt az eloszlás vizsgálata, másrészt pedig az volt, hogy az innovációs tevékenység térbeli sűrüsödését is megmagyarázzák bizonyos meghatározó háttérváltozókkal. Mind a MAR externáliák (a helyi ipar specializáltsága), mind a Jacobs-féle externáliák (a helyi ipar változatossága) hatását igyekeztek felmérni, ennek megfelelően a területi LQ értékeket és egy úgynevezett diverzifikáltsági mutatószámot alkalmaztak, amely az LQ definíciójában szereplő $s_{i}$ értékekből számolható ${ }^{26}: D I V_{i}=\left(\frac{s_{i}}{s_{i}}\right)^{2}$.

Regressziós elemzésükben, melynek eredményváltozója az egy főre eső innovációs aktivitás volt, olyan magyarázó változók szerepeltek, mint a $\mathrm{K}+\mathrm{F}$ kiadások a GDP százalékában, egy före jutó GDP, a feldolgozóipar aránya a termelésben és az egyes országokhoz való hozzátartozás alapján készült dummy változók. Mindezt pedig mindkét időszakra kiszámolták, így egyszerübb dinamikus elemzésre is lehetőségük volt. Mindezen túl pedig feltételezték, hogy a tudás termelésének régióhatárokon túlívelő hatása is van, így térbeli autokorrelációra is lehet számítani a modellben. Ennek okán egy térben késleltetett modellt alkalmaztak, amely figyelembe veszi szomszédos régiók eredményváltozó-értékeit is.

Megállapították, hogy mind a 23 feldolgozóipari ágazatban koncentrált az innovációs tevékenység, és időben egyre koncentráltabbá válik. Szinte minden ágazatban a régióhatárokon túlnyúlt a koncentráltság (térbeli autokorreláció), ezt többek között Moran index számítással igazolták és a 23 ágazat összehasonlításához kiszámították azt a szomszédsági szintet, amely mellett még szignifikáns volt az autokorreláció. Regressziós eredményeik azt sugallják, hogy az ágazati innováció specializációja nagymértékben és pozitívan befolyásolja az innovációs aktivitás mértékét, miközben a diverzifikáltsági mutató nem volt szignifikáns. A térbeli autokorreláció általában az egyes országokon belül jelentkezett, és az egyes országokhoz való hozzátartozás alapján készült dummy változók is szignifikánsak voltak, tehát a két legfontosabb befolyásoló tényező a nemzeti és térbeli szomszédság volt.

Moreno társai, Usai és Paci (2000) korábban hasonló vizsgálatot végeztek ugyancsak szabadalmakra, de csak Olaszországra, adataik az 1990-91-es évekből származtak. Elemzésüket 85 ipari ágazatra végezték el, térfelosztásuk eltért a szokásos NUTS-LAU rendszerétől, ők 784 olasz munkaeröpiaci régiót (Local Labour System) vettek alapul, amelyeken olyan településrendszereket értenek, amelyekben nagyon magas szintü a munkaerő

\footnotetext{
${ }^{26}$ Itt $s_{\dot{t}}$ annak a területi egységnek az $s$ értéke, amelyet úgy kapunk, hogy az i-edik területi egységet az egészből kivéve, a megmaradó területi egységeket egynek vesszük.
} 
belső áramlása pl. ingázás formájában. Moran index számítással igazolták, hogy nagyon erős térbeli autokorreláció tapasztalható az adatokban még harmadfokú szomszédsági mátrix alkalmazása esetén is ${ }^{27}$. Ez nem is meglepő, ha figyelembe vesszük, hogy a térfelosztás mennyire mély. Ezután térökonometriai eszközökkel - regresszió az eredményváltozó és néhány magyarázó-változó térbeli késleltetésével - igyekeztek felmérni a specializáltság és a összetett, változatos ipar hatását a szabadalmi tevékenységben megnyilvánuló innovációs aktivitásra.

Azt találták, hogy a MAR externáliák (a területegység specializáltsága az adott iparágra) - amelyeket LQ mutatóval mértek -, és a Jacobs-féle externáliák (a változatos, sokszínü ipari paletta) - ezeket a Gini index reciprokának segítségével szerepeltették a modellben nem ellentétes irányban hatnak, hanem mindkettő pozitív hatással van az innovációs tevékenységre, ahogyan a vizsgált ágazatéval azonos tudásbázissal rendelkező ágazatok jelenléte is pozitív együtthatóval jelentkezett a modellben. Még nagyobb ez a hatás akkor, ha az adott területi egység nagyvárosias régió, vagy abban az esetben, amikor az adott ágazat high-tech ipari ágazat. Az eredményváltozó térbeli késleltetése is pozitív hatást mutatott, vagyis a területegységek határain túlnyúlik a technológiai túlcsordulás, azonban szignifikáns és pozitív hatása csak a másodfokú szomszédságnak van, azon túl ez a hatás már lecseng.

A két vizsgálat, bár sok hasonlóságot mutat, mégis számos ponton különbözik egymástól. Egyrészt óriási különbségek vannak a térfelosztási szintekben, másrészt az ágazati bontás is más és más. Ezért aztán a két vizsgálat eredményei is nagy különbségeket mutatnak. Itt ismételten utalnunk kell arra, hogy a térbeli vizsgálatok eredményei minden esetben csak az éppen aktuális térfelosztási szintre érvényesek - lásd: a módosítható területi egység problémája (Dusek 2004).

\subsection{Agglomeráció-koncentráció kettős vizsgálata}

Készült néhány olyan nemzetközi tanulmány is, amelyek kifejezetten azt a komplex képet igyekeztek felmérni, amely a korábban említett agglomeráció-koncentráció kettősségből fakad, tehát mind térbeli sürüsödés, mind pedig térbeli autokorreláció mérését eszközként használták. Ezek általában már a 2000-es években készültek, ahogyan a módszertani háttér egyre fejlettebb lett.

\footnotetext{
27 Vagyis a bástya szomszédságot reprezentáló mátrix harmadik hatványa esetén, ami a három lépésben elérhető szomszédokkal való összeköttetéseket reprezentálja.
} 
Sohn (2004) az USA 361 feldolgozóipari szakágazatára (SIC osztályozás négyjegyü szint) 3110 megyére végzett vizsgálatot az 1997 évre. Koncepciója szerint két dimenzió - a földrajzi, illetve a gazdasági kapcsolat - mentén érdemes osztályozni az egyes ágazatokat, és ezt az osztályozást el lehet végezni az ágazatokra, illetve ágazat párokra is. Ennek megfelelően többféle adat felhasználására van szükség, amelyek jelen esetben a következők voltak: szakágazatok közötti input-output tábla és foglalkoztatottsági adatok az egyes szakágazatokra megyénként. Publikációjában elsősorban a szakágazaton belüli kapcsolatra fókuszált, ennek megfelelően az I-O tábla föátlójában lévő elemek kapcsolatát vizsgálta a foglalkoztatottsági adatok alapján készült (szakágazati) térbeli Gini mutatókkal, illetve a (szakágazati) Moran index értékekkel.

Eredményei szerint általában két csoportra oszthatók a szakágazatok a földrajzi koncentráció tekintetében. Lafourcade és Mion fogalomrendszerével élve azon szakágazatok, amelyek megyei szinten koncentrálódnak, nem mutatnak kifejezett agglomerálódást, illetve az agglomerálódott szakágazatok nem mutatnak túlzottan magas térbeli koncentrációt (magasabb Gini mutató értékhez alacsonyabb Moran index értékek tartoznak és fordítva). Ez pedig azt jelenti, hogy más és más területi felosztási szinten mérhető az egyes szakágazatokban az a hatás, ami egymáshoz közel vonzza a vállalatokat, vagyis ami a szakágazati tevékenységek sürüsödéséhez vezet.

A másik fontos eredménye szerint azon szakágazatok, amelyeknek az I-O tábla főátlójában lévő értéke magas - vagyis amelyekben a vállalatok szoros gazdasági kapcsolatban állnak egymással -, magasabb Gini mutató értékkel rendelkeztek, tehát koncentráltabbak voltak.

Carroll és társai (2008) az LQ értékeket és a Getis-Ord féle $G_{i}^{*}$ mutatót vizsgálták módszertani cikkükben. Négy USA-beli tagállamban (Indiana, Illinois, Ohio és Michigan) kerestek választ arra, hogy melyek azok a megyék (county), amelyek potenciális jármüipari klaszter régiók lehetnek. Adataik 2002-ből származtak. Ők tehát egyetlen iparágat vizsgáltak 365 megyében, és elsősorban arra fókuszáltak, hogy a megyéket osztályozzák az iparág szempontjából (3. táblázat).

3. táblázat: Megyék osztályozása az autóipar szempontjából

\begin{tabular}{|l|c|c|}
\hline & $L Q>1$ & $L Q<1$ \\
\hline$G_{i}^{*} \geq 1,96$ & potenciális jármüipari régió & jármüipari periféria \\
\hline$G_{i}^{*}<1,96$ & járműiparra specializálódott megye & jármüipar-mentes megye \\
\hline
\end{tabular}

Forrás: Carroll és társai $(2008,458$. o.) 
Érdemes megemlíteni a $G_{i}^{*}$ mutatójukhoz használt szomszédsági mátrixot, amelyet speciálisan a jármüiparnak megfelelően választottak meg. Egy távolságalapú mátrixról van szó, melyben $w_{i j}=\frac{1}{d_{i j}}$, ahol $d_{i j}$ az i-edik és j-edik megye középpontjai közötti távolságot jelöli, és maximálisan 450 mérföld lehet. Azért ezt az értéket adták meg, mert ekkora az egy nap alatt megtehetö közúti távolság.

Arbia és társai (2006) egy összefoglaló tanulmányt adtak ki, amely a gazdasági tevékenységek térbeli eloszlásának elemzését, módszertanának bemutatását és Olaszországra való alkalmazását tűzte ki célul. Ök 23 feldolgozóipari és 17 szolgáltatási ágazat esetében vizsgálták meg mind a térbeli koncentráció, mind pedig az agglomeráció esetleges jelenlétét. Nem csak a NUTS rendszer alapján dolgoztak, hanem NUTS2 és NUTS3 térfelosztási szintek mellett az említett olasz munkaerö-piaci régiókat (Local Labour System) tették meg elemzésük alapjának, ezekből az adataik időpontjában (1991 és 2001) 784, illetve 686 egység volt.

Azt találták, hogy az EG $\gamma$ mutató a térbeli aggregáció magasabb szintjénél nagyobb értéket mutat, és a dinamikus vizsgálat arra utal, hogy az ipari tevékenységek egyre szétszórtabbak térben, ellenben a szolgáltatások körében koncentrálódás fedezhető fel. Ennek okát ők elsősorban a csökkenő szállítási költségekben látják: ezért van az, hogy amíg a szolgáltatások - amelyek jellegüknél fogva sokkal kevésbé „kereskedelemképesek”, mint az feldolgozóipari termékek - a közlekedés csökkenő költsége miatt koncentráltabbá válhattak, addig az ipari ágazatok koncentrációja csökkenhetett, hiszen a szállítási költségekből fakadó agglomerációs előny csökkent. A leginkább koncentrálódottnak a tradicionális iparágak és a high-tech ágazatok bizonyultak.

A térbeli autokorreláció mérését ők is Moran index számításával valósították meg, azonban nem a dolgozatomban bemutatott $d_{i}=s_{i}-x_{i}$, hanem az $L Q_{i}=\frac{s_{i}}{x_{i}}$ értékek alapján számították ki azt, súlymátrixként az elsőfokú szomszédsági mátrixot alkalmazva. Eredményeik szerint az ágazatok több mint 90\%-a szignifikánsan agglomerálódott, elsősorban és leginkább az alacsony technológiai színvonallal rendelkező ipari ágazatok. Azokban az ágazatokban, amelyekben a belső méretgazdaságosság a fő hatóerő, ez pedig a nagy vállalati mérettel jöhet létre, a koncentráció jelentös, viszont agglomerálódásra utaló jeleket kevésbé találunk (vegyipar, autóipar). Az olyan ágazatokban viszont mind a koncentráció, mind az agglomeráció magasnak mutatkozik, amelyek jól definiált specializálódott régiókban találhatók (textilipari régió Toszkánában). 
Lafourcade és Mion (2007) tanulmánya ugyancsak az olasz munkaerőpiaci régiókra vonatkozott, azonban csak feldolgozóipari ágazatokat vizsgáltak. Voltak adataik 1981-re és 1991-re NACE 3-jegyű ágazat-felosztási szinten, és 1996-ra 5-jegyű szinten, viszont az egységes vizsgálat érdekében a 2- és 3-jegyü ágazatokat vették alapul. Ezen túl alkalmaztak egy harmadik felosztást is, a vállalkozásokat két kategóriába sorolták: kis (20-nál kevesebb alkalmazott) és nagy (legalább 20 alkalmazott).

A térbeli koncentráció méréséhez felhasználták mind Ellison és Glaeser $\gamma$ mutatóját, mind pedig annak a Maurel és Sédillot által módosított változatát. Az agglomeráció mérését is kétféle mutató segítségével valósították meg, ez a Moran index két változata volt. Az egyik esetében a $\mathrm{d}_{i}=\left(\mathrm{s}_{i}-\mathrm{x}_{i}\right)$ értékek, a másikban pedig a $\left(\mathrm{q}_{i}-\mathrm{x}_{i}\right)$ értékek térbeli összehasonlítása volt a cél, ahol $\mathrm{q}_{\mathrm{i}}$ nem az ágazatbeli foglalkoztatottak helyett, az ágazatbeli vállalkozások adott területi egységbe eső hányadát jelöli. A térbeli kapcsolatok mátrixa távolság alapú volt.

Az adott felosztási módszerek mellett a szerzők számításai szerint a kisvállalkozások térben kevésbé koncentrálódnak, mint a nagyok, az agglomerálódás viszont fordított mintát követ, éppen a kisvállalkozások agglomeráltsága bizonyult magasabb fokúnak, mint a nagyobbaké. Erre a magyarázat az, hogy a nagy vállalkozások kisebb területi egységekben való együttes megjelenése kedvez a termelékenységnek, mert pl. munkaeröpiac (amely a térfelosztás alapja volt e vizsgálat során) jelenléte növeli azt, viszont - mivel ezek többnyire exportra termelnek - a belföldi távolságra érzéketlenek. A kisvállalkozások ezzel szemben egy olyan közelséget preferálnak, amelynek egy nagyobb térfelosztási szint lehetne az alapja.

A kis- és nagyvállalkozásokon együttesen mért térbeli koncentráció a Maurel és Sédillot $\gamma$ mutató alapján többek között a textilipari, a böripari, a kerámiagyártás, a hangszergyártás és a gyógyszeripari ágazatokban volt a legmagasabb, és ez a textiliparban elsősorban a kis vállalatok koncentráltságának köszönhető, míg a többi esetben egyenlő részben a kis- és a nagy vállalatok koncentráltságának. Ezen ágazatok közül csak a hangszergyártás bizonyult agglomeráltnak. A legnagyobb agglomerálódást mutató iparágak között nagyon sok élelmiszeripari ágazat található és más olyan ágazatok, amelyek készterméket gyártanak, ez azt támasztja alá, hogy az ilyen ágazatok inkább a felvevőpiacukhoz való közelség miatt települnek közel egymáshoz.

A szerzők ugyanezeket az eredményeket kapták abban az esetben is, mikor a mérés NUTS 3-as régiók (provinciák) szintjén történt, de az egyes mutatók értékei minden esetben nőttek. Az ágazat felosztási szintet is változtatták, 2-jegyű ágazatokat is vizsgáltak munkapiaci régiók szintjén, ebből pedig azt a következtetést vonták le, hogy a kapcsolat 
ezeken belül gyengébb, hiszen a térbeli koncentráció átlagosan kisebb, de sokkal inkább távolság alapú a kapcsolat, mert több esetben található agglomerálódás, mint a 3-jegyủ szint esetében. Én ennek okát abban látom, hogy a 2-jegyü ágazatokon belül több esetben ellátási láncok müködnek, melyek vállalatai különbözö 3-jegyű ágazatokhoz tartoznak, és ezek szempontjából fontos a közelség a szállítási költségek csökkentése érdekében.

A szerzők végeztek dinamikus vizsgálatot is, ennek során azt találták, hogy az átlagos térbeli koncentráció folyamatosan csökkent, míg az agglomerálódás növekedett, és ez elsősorban a kisvállalatok mozgásainak köszönhető, a nagy vállalkozások inkább stabilak maradtak.

\subsection{Tudás túlcsordulásra irányuló vizsgálatok}

A regionális gazdasági növekedési elméletek elsősorban arra igyekeznek megadni a választ, hogy milyen tényezőktől függ a régiók gazdasági növekedése. Az irányzatok alapvetően két nagy csoportba sorolhatók (Lengyel 2010a, Varga 2009): az egyik abból indul ki, hogy a spontán piaci automatizmusok bizonyos feltételek esetén mindegyik régió növekedését létrehozzák. Az irányzatok másik csoportja szerint a gazdasági növekedés nem automatikus és térben egyenlőtlen, ezért a kormányzatoknak be kell avatkozni. Ha be kell avatkozni a gazdaság működésébe, akkor alapkérdés, hogy ki és milyen módon tegye azt.

A területi egységek innovációs képessége ezért egyre nagyobb érdeklődésre tarthat számot, amit egyrészt a térségek saját innovációs potenciáljának minél hatékonyabb felhasználása és megértése érdekében tett lépések indokolnak. Másrészt az innováció-politika azon felismerése is fontos, mely szerint a térség egyedi feltételeihez igazodó beavatkozásokra van szükség (Bajmócy 2012).

A tudásintenzív ágazatok struktúrája, müködése és sikeressége szempontjából tehát érdekes, hogy ezen ágazatok müködéséhez nélkülözhetetlen erőforrásokat milyen jellegü helyi - regionális, térségi - innovációs potenciál biztosít. Ezen túl pedig fontos az is, hogy ezekre a helyi feltételekre miként hat vissza az egyes ágazatok szerkezete, beleértve azok térbeli eloszlását is.

Minden ágazatban keletkezik új tudás és technológia, illetve használnak más ágazatokban létrejövő újdonságokat, de az új tudás teremtésének, avagy felhasználásának az intenzitása ágazatonként más és más lehet. Ezért megkülönböztetünk tradicionális és tudásintenzív ágazatokat, mely utóbbi csoportra jellemző a magas technológiai színvonallal 
rendelkező termékek és tevékenységek létrehozása, illetve fogyasztásuk. Így tehát tudásintenzív az az ágazat is, amelyben a vállalatok magasan képzett munkaerőt alkalmaznak, hogy a technológiai innovációkban, illetve az új technikai megoldásokban rejlö tudást kiaknázzák (OECD 2001).

A szakirodalom szerint a tudás túlcsordulás (knowledge spillovers) egy nagyon erös tényező a vállalatokat egymáshoz közelségébe vonzó egyéb faktorok között (Varga 2009). A fogalom maga azt jelenti, hogy amikor egy vállalat (vagy egy kutatóintézet) valamiféle tudást teremt például kutatás útján, akkor ennek a tudásnak egy szignifikáns része kijut a vállalatból (Jaffe 1986). Ha ez a tudás tacit, vagyis nem kodifikálható tudás, akkor a terjedése nem lehetséges nagy távolságokon keresztül, mivel átadásához személyes kapcsolat, térbeli közelség szükséges. Azonban az éremnek van másik oldala is, ugyanis a tudás externáliák „kiszippantása” az externáliát létrehozó vállalat számára egyúttal hátrányt is jelent, hiszen a versenytárs esélyeit növeli. Tehát míg a tudást „kiszippantó” vállalat törekvése a koncentrálódás irányába hat, addig a tudást megteremtő vállalat inkább kívánna távolabb helyezkedni (Alsleben 2005).

Krugman a gazdaság térbeli koncentrálódásának okai között a tudás túlcsordulást nevezi meg harmadikként, egyben utolsóként a Marsall által megjelölt okok között. Ezt teszi azért, mert egyrészt az empíria arra enged következtetni, hogy nem csupán a magas technológiai színvonallal rendelkező iparágak koncentrálódnak térben (Szilícium-völgy), hanem más ágazatok is (daltoni szőnyegipar), másrészt pedig ez a legnehezebben vizsgálható terület a három közül.

Alecke és társai (2006) empirikus vizsgálatuk során arra a meglepő eredményre jutottak, hogy a tudásintenzitás, vagy $\mathrm{K}+\mathrm{F}$ tevékenységek és a német feldolgozóipari ágazatok koncentrálódása között nincs szignifikáns kapcsolat. Combes és Duranton (2006) egy olyan duopólium modellel állt elő, amely megmagyarázhatja ezt az eredményt. Az, hogy a munkapiac, amely a speciálisan képzett munkaerőt tömöríti, egy bizonyos területre sűrüsödik, vonzóerőt jelenthet a vállalatok számára, azonban egyben taszíthatják is egymást, hiszen a munkaerő „lehalászása” valós veszélyt jelenthet. A modell első lépése az, hogy a vállalatok eldöntik, azonos, vagy különböző helyszínekre települnek. A második lépésben munkaerőt toboroznak, amely származhat a másik vállalat kötelékéből is, amennyiben az a közelben termel. Harmadik lépésként megkezdik differenciált termékeik gyártását, amelynek költségessége függ attól, hogy mennyi tapasztalt munkaerőt sikerült alkalmazniuk. Ezután újból kezdődik az első lépés. Combes és Duranton (2006) igazolták, hogy a vállalatok a munkaerö-lehalászás elkerülése érdekében sok esetben a különböző telephelyekre költözést 
választják. Alecke és társai német empirikus eredményeinek magyarázatára stilizált Cournotmodellt dolgozott ki Alsleben (2005).

Frank (2008) német filmhez kapcsolódó ipari és szolgáltatási ágazatok esetére állított fel regressziós modellt, és éppen a Combes és Duranton által megfogalmazott, a vállalatok munkaerő lehalászástól való félelmére keresett empirikus bizonyítékot. Minden egyes filmipari szolgáltatási szakágazatra $(\mathrm{k}=1, \ldots, 60)$ kiszámította az általuk normalizált Hirschman-Herfindahl-indexnek nevezett $h h i_{k}=\sum\left(s_{i}-x_{i}\right)^{2}$ értékeket (minél nagyobb az érték, annál nagyobb a koncentráció). Ezt, mint eredményváltozót becsülte olyan magyarázó változókkal, mint a filmiparnak nyújtott szolgáltatások aránya az összes szakágazatbeli szolgáltatásokon belül, azon vállalatok száma, amelyek az adott szolgáltatást nyújtják és a vállatok szakmunkásainak betanulási idejét. Azt találta, hogy a szolgáltatás piacának (a filmipar) koncentrációja pozitív hatással volt a szakágazatok koncentrációjára. Ezen kívül minél hosszabb a betanulási idő, annál koncentráltabb a szolgáltatási ágazat, azonban kis piacokon (vagyis amely szakágazatokban kevés vállalat müködik), csak akkor koncentrálódnak ezek, ha a munkások nehezen tudnak egyik vállalattól a másikhoz szegődni, a sokvállalatos szolgáltatások körében nincs ilyen félelem, inkább a nagy munkapiac vonzóereje munkál, ezek koncentráltabbak lesznek.

Griliches (1992, 13. o.) a következőképpen definiálta a tudás túlcsordulást: „hasonló dolgokon munkálkodni és így egymás kutatásából előnyre szert tenni."

Feldman (2000) azt találta, hogy alapvetően négy olyan módszer ismert, amellyel empirikusan vizsgálták a tudás túlcsordulás térbeli összefüggéseit:

1. Tudástermelési függvény (JFV - Jaffe-Feldman-Varga-függvény): az eredetileg nem térben értelmezett függvény (Griliches 1979), Jaffe (1989) által továbbfejlesztett változatába már a térbeliség is belevihetö, a függvény a következő formát ölti:

$I_{s i}=I R D^{\beta_{1}} \cdot U R_{s i}^{\beta_{2}} \cdot \varepsilon_{s i}$

Itt $I$ az innovatív output értéke, $I R D$ a vállalati privát $\mathrm{K}+\mathrm{F}$ kiadások, az $U R$ pedig azon kutatásra fordított kiadás, amelyet egyetemek végeztek el, $s$ jelöli az állam, $i$ pedig az output sorszámát.

Ezt később Feldman (1994) kiegészítette a területi egységben jelenlévő ipar által megtestesített tacit tudással, valamint az üzleti szolgáltatások jelenlétével, ami az új termékek piacravitelével áll kapcsolatban. Empirikus vizsgálatok (ÁcsAudretsch-Feldman 1994) során az derült ki, hogy a kisebb vállalatok 
elsősorban az egyetemi kutatásokból profitálnak, míg a nagyobb vállalatok az ipari kutatások eredményének felhasználói. Kutatásukban azonban a térfelosztási szint túl nagy alapegységei (USA tagállamok), valamint a térökonometriai eszközök: szomszédsági-távolsági viszonyok figyelembevételének hiánya miatt ez további fejlesztési lehetőséget rejtett magában (Ács 2009, Varga 2009).

Anselin, Varga és Ács (1997) valamint Varga (1998, 2009) által közölt eredmények már az USA nagyvárosi régióinak szintjére vonatkoztak, és térökonometriai módszereket alkalmaztak.

2. Szabadalmak: Jaffe, Trajtenberg és Henderson (1993) az USA-beli szabadalmakat és azok idézettségét vizsgálta területi szinten 1975 és 1989 között. Kiemelik Krugman (2003, 70. o.) állítását: „Az ismeretek áramlása ezzel szemben [a munkapiac egyesítésével és a félkész termékek kínálatával szemben] láthatatlan, nincs papír róla, amelynek segítségével mérni, megfogni lehetne..." azonban meglátásuk szerint ,a tudás áramlása gyakran mégis hagy nyomot papíron maga után", méghozzá szabadalmaztatott újítások és új termékek bevezetése esetén. Így a tudás áramlásának mérését ők 1975-ben és 1980-ben az USA-ban egyetemi kutatóintézetek, illetve belföldi vállalatok által bejegyeztetett szabadalmak és azok idézettségének térbeli eloszlása közötti kapcsolat regressziós vizsgálatával végezték.

3. Személyek: néhány tudós azt feltételezi, hogy a tudás elsősorban azokban az emberekben halmozódik föl, akik az adott területen szükséges készségekkel, képességekkel és know-how-val rendelkeznek. Zucker és Darby (1996) a biotechnológiai tudás terjedését vizsgálta bizonyos „sztár-tudósok” által írt folyóiratcikkeket alapul véve. Azt találták, hogy az USA-ban a lokalizált intellektuális tőke kulcsfontosságú a biotechnológiai ipar fejlődésében és a tudás olyan externáliákat generál, amelyek földrajzilag azokhoz a régiókhoz kötődnek, amelyekben a „sztár-tudósok” dolgoznak.

4. Termékek: ebben az esetben azt feltételezik, hogy a tudás a javakban, vagyis a termékben van jelen, így a termék kereskedelme az elsődleges útvonala a tudás terjedésének.

Breschi (1998) a tudás túlcsordulást a következő proxy változókkal mérte: helyi K+F kiadások, és az összes helyi innovatív tőkebefektetések nagysága. Van Oort és Atzema (2004) hangsúlyozzák, hogy a tiszta innovációt mérő indikátorok, mint a szabadalmi bejelentések 
(lásd például Breschi 1998, Usai és Paci 1999, Moreno és társai 2005), vagy a szabadalomra való hivatkozások (Zitt és társai 1999, Jaffe és társai 1993) nem elegendőek a tacit tudás terjedésének mérésére. Az ugyanis személyek közötti interakciókban, különböző vállalatok alkalmazottainak informális kapcsolatai révén, vagy a tudás birtokosának munkahelycseréjével valósul meg. Különösen a tudásnak az egyik legfontosabb típusa, amely a növekedésben és az innovációs folyamatokban szerepet játszik, nem feltétlenül áttörö innováció, hanem gyakran csak egyszerủen hétköznapi emberek számára nyújtott tanulási lehetőség.

Három alapvető koncepciót sorolnak fel, amelyek a tudás túlcsordulás gazdasági növekedésben játszott szerepét, illetve annak müködési mechanizmusát írják le, majd egy negyedik koncepciót is, ez pedig az előző három kiegészítője lehet (Van Oort - Atzema 2004):

1. Marshall (1920) gondolatmenete szerint (amelyet később Arrow (1962) és Romer (1986) formalizált) a tudás alapvetően iparág specifikus, és mivel térbeli közelség szükséges az átadásához, a regionális specializáció az, ami a növekedés és új vállalatok létrejöttéhez szükséges.

2. Porter (1990) egyetért Marshallal abban, hogy a tudás iparág specifikus, azonban szerinte a tudás nem csak a koncentráción, hanem elsősorban a helyi verseny miatt mozdítja elő a gazdasági növekedést, hiszen az a vállalat, amely a versenyben talpon kíván maradni, innovatív kell, hogy legyen.

3. Jacobs (1969) hipotézise szerint a verseny valóban pozitív hatással van a regionális növekedésre és új vállalatok megjelenésére, azonban a tudás nem feltétlenül iparág specifikus, sok esetben lehetséges, hogy egy adott iparágban kifejlesztett innováció gyümölcsöző eredményeket képes hozni más iparágakban való alkalmazás esetén is. Eszerint tehát a diverzitás, azaz a változatos, sokszínű gazdasági aktivitási paletta az, amely a verseny mellett a legnagyobb hatással lehet a növekedésre.

4. A negyedik koncepció valójában az előzőek ellenhipotézise, mely szerint sem a verseny, sem a koncentráció nincsen hatással a növekedésre, a növekedés mozgatórugója csak az, hogy egyszerre minél több iparág van jelen a régióban, tehát egyedül a diverzitás foka a döntő.

Az általuk vizsgált kérdés az volt, hogy a négy koncepció közül melyik közelíti a legjobban a valóságot. Ehhez holland adatokat használtak az 1996-2000 közötti évekből, és 
vizsgálatukat egyetlen bővebb ipari szektorra végezték el: az infokommunikációs technológiák (IKT) szektorára, amely magában foglalt feldolgozóipari, kereskedelmi és szolgáltatási ágazatokat. Térbeli felosztási szintjük lement egészen településekig, összesen 580 területi egységet vizsgáltak.

Hipotéziseik ellenőrzése érdekében a következő háttérváltozókat használták:

1. Az egyes területi egységek IKT szektorra specializáltságának mértékét LQ index segítségével mérték.

2. Az adott területi egységben az IKT szektorbeli verseny nagyságát az egy munkásra jutó vállalkozások számának területi egységre vonatkozó értéke adta az országos átlag százalékában.

3. Az iparági diverzitás mérésére a Gini együtthatót használták, minden területi egységre külön-külön kiszámolva azt a foglalkoztatottak 49 szektorban való eloszlása alapján. Itt a magasabb értékek alacsonyabb diverzitási fokot jelentenek.

Empirikus munkájukban elsősorban a növekedés egy speciális megnyilvánulási formájára, az új vállalatok megjelenésére fókuszáltak, ugyanis meglátásuk szerint az új vállalat telephely-választási döntésében tisztán a vizsgálni kívánt körülmények (a verseny, az eleve meglévő koncentráció, illetve az iparágak változatossága, diverzitása) játszanak szerepet, míg a régi vállalatok esetében az elsüllyedt költségek is.

Moran index használatával (inverz távolság alapú szomszédsági mátrix segítségével) igazolták, hogy nagyfokú a pozitív autokorreláció az előbb felsorolt adatok, köztük az LQ értékek esetében, így érdemes térbeli késleltetésü regressziós modellt alkalmazni az egyes koncepciók vizsgálatára.

Megállapították, hogy mind az IKT szektor koncentrációja, mind a verseny, mind pedig a diverzitás pozitív hatással van az új vállalatok telephelyválasztására. De ezek közül mégis kiemelkedik a verseny, vagyis minél kisebb az IKT vállalatok átlagos foglalkoztatotti létszáma az adott területi egységben, annál több új IKT vállalat jelenik meg ott. Abban az esetben, amikor térbeli késleltetést is alkalmaztak, a kép változott, a diverzitás többé már nem szignifikáns befolyásoló tényező, így a szerzőknek összességében az IKT szektor esetében a Porter féle koncepciót sikerült alátámasztaniuk. 


\subsection{Következtetések a nemzetközi vizsgálatok alapján}

A szakirodalom áttekintése után véleményem szerint négy lényeges szempontja lehet a következtetéseknek: az ágazatfelosztási és térfelosztási szintekre vonatkozó vizsgálatok, illetve a regressziós és a dinamikus elemzések eredményeit lényeges összefoglalni.

Az egyszerre több ágazat-felosztási szint szerinti térbeli koncentrációs vizsgálatok különféle mintákat mutatnak. A nyersanyagigényes ágazatok általában az ágazat-felosztási szint mélyülésével egyre nagyobb EG $\gamma$ értékekkel rendelkeznek (lásd például Ellison Glaeser 1997, Maurel és Sedillot 1999, Lafourcade és Mion 2007), mert a térbeli koncentráció elsősorban a MAR externáliáknak vagyis a lokalizációs előnyöknek köszönhető. A high-tech iparágak ezzel szemben mélyebb ágazat-felosztási szinteken kevésbé koncentráltak térben az EG $\gamma$ mutató alapján, mint magasabb szinten, hiszen ezek inkább abból profitálnak, ha más szakágazatok is jelen vannak a telephelyükön, vagyis esetükben a Jacobs externáliák, az urbanizációs előnyök érvényesülnek inkább. Az olyan ágazatokban, amelyekben ellátási láncok müködnek, vagyis az egyik szakágazat beszállítója a következőnek, az pedig egy újabbnak és így tovább - például a papírgyártás, könyvnyomtatás, könyvkiadás -, a kép köztes, az EG $\gamma$ értékek közel állandóak, itt a tevékenység-komplexitási elönyök érvényesülnek leginkább (lásd például Maurel és Sedillot (1999) és Lafourcade és Mion (2007) eredményeit.

A térfelosztási szint (területi aggregációs szint) változtatása esetén is különböző eredmények születtek. A Spanyolországra vonatkozó vizsgálat (Alonso Villar és társai 2004) nem tárt fel lényeges különbséget a mutatószámok értékei között, vagy legalábbis nagyon erős a korreláció a különböző térfelosztási szintekhez tartozó értékek között (például Belgiumra Bertinelli - Decrop 2005). Az Olaszországra vonatkozó elemzések viszont minden esetben növekedést jeleztek a térbeli koncentrációs mutatószámok értékeiben, ha a területi aggregáció magasabb szintjén számították azt (Lafourcade - Mion 2007, Arbia és társai 2006).

A tudás túlcsordulás hatásának regressziós vizsgálatai során az eredmények általában szignifikánsak voltak, és rendszerint mélyebb térfelosztási szint mellett jelent meg erősebb szignifikancia, tehát a tudás túlcsordulás térben viszonylag „gyorsan” lecseng (lásd például Rosenthal - Strange 2001, Usai és Paci 2000).

A regressziós elemzések többnyire kimutatták a nyersanyagigényes ágazatok térben jelentős koncentráltságát, de legfontosabb tényezőnek mégis a belső méretgazdaságosság 
tünik (például Svédország, az Egyesült Királyság és Olaszország esetében), néhány esetben pedig a helyi inputpiac és a munkaeröpiac koncentrált jelenléte bizonyult lényegesnek.

A tudásintenzív ágazatok térbeli koncentráltságáról nem kaphatunk egységes képet, viszont az elmondható, hogy az innovációs tevékenység minden esetben térben jóval koncentráltabban jelent meg, mint más tevékenység, vagy akár a népesség. Egyes vizsgálatok arra utalnak, hogy a tudásintenzív ágazatok térben erősebben koncentrálódnak, mint a nem tudásintenzívek, más esetekben ennek éppen az ellentéte tapasztalható, vagy az, hogy átlagos térbeli koncentráltsággal rendelkeznek. Jaffe és társai (1993) és Audretsch és Feldman (1996) vizsgálatai, amelyek az USA-ra vonatkoztak, azt sugallják, hogy erős koncentrálódás tapasztalható a tudásintenzív ágazatok esetében, míg más vizsgálatok, köztük Devereux és társai (2003) az Egyesült Királyságra valamint Barrios és társai (2005) Belgiumra, Portugáliára és Írországra vonatkozó eredményei alapján nem mutatható ki különösebben erős koncentráció a tudásintenzív gazdasági tevékenységek esetében.

A kép azért ilyen sokszínü, mert egyrészt az egyes vizsgálatok más-más módszertant alkalmaztak, és igen változatos volt mind a térfelosztási szint, mind pedig az az ágazati beosztás, amelyeket az egyes elemzésekben használtak. Ha a vizsgálat még ugyanazon térfelosztási szint mellett történik is, ezek is országonként eltérnek egymástól. A NUTS rendszer sem képes még országokon belül sem kiküszöbölni a térségek eltérő méretéből adódó egyenetlenségeket, a vizsgálatok több esetben pedig nem is a NUTS rendszer alapján történtek. Így a módszertan átvehető, de következtetés nehezen vonható le az eredmények változatosságából.

Másrészt az eltérő fejlettségü és eltérő történelmi háttérrel rendelkező országok másmás térbeli gazdaságszerkezettel rendelkeznek és általánosságban elmondható, hogy a társadalmi, gazdasági mutatók értékeinek összehasonlíthatósága problémás, mert ugyanazon mutató mögött más és más intézményi háttér, településszerkezet és történelem van. Ez azért jelenthet nagy különbségeket, mert különböző időpontokra tehető a koncentrálódás időszaka az eltérő fejlettségü országokban, és azért is, mert például az ipari forradalom koncentráló hatása "érett preindusztriális városhálózatba" épült be Európában, így Európán kívül mindenhol lényegesen nagyobb területi egyenlőtlenségeket hozott létre (Enyedi 2012). Kimutatható esetenként az útfüggőség is, erős a korreláció a térbeli koncentráltság mutatószámainak eltérő időpontokban kiszámított értékei között.

A gazdasági tevékenységek térbeli eloszlása egy dinamikus folyamat állandóan változó eredménye, amely többféle hatás következményeként jön létre. Vállalkozások szünnek meg, új vállalkozások jönnek létre, amelyek sok összetevő együttes hatására telephelyet 
választanak és természetesen már meglévő vállalkozások is telephelyet változtathatnak. Éppen ezért, ha e dinamikusan változó képről egy pillanatfelvételt mutatunk be, abból nem állapítható meg könnyen, hogy milyen folyamatok zajlanak a háttérben.

Egy tradicionális ipari ágazat magas koncentráltsága kifejezetten múltbéli, hosszabban fennálló extern hatások eredménye lehet, amelyek hatása még a jelenben érzékelhető, miközben már az ágazatban esetleg éppen a dekoncentrálódás irányába ható erők dominánsak - ezt mutatták ki Olaszországra Lafourcade és Mion (2007) és Arbia és társai (2006). Ezzel szemben egy magas tudásintenzitással rendelkező ágazatban a koncentrálódás irányába ható erők dominánsak és a továbbiakban is fennállnak, ezek eredményeként mérhető magas koncentrálódás az ágazatban (Maurel-Sédillot 1999), de ugyanígy a szolgáltatások is sok esetben térben egyre koncentráltabbá válnak (lásd például Arbia és társai 2006).

A gazdasági tevékegységek térbeli koncentrációját és agglomerációját egyaránt mérő elemzésekben sem látható egységes kép arra vonatkozóan, hogy a mutatószámok között milyen összefüggés lehet. Esetenként különböző eredmények születtek, van ahol együttmozgás, van ahol kifejezetten ellentétes irányú összefüggés található a mutatók között és arra is található példa, hogy ezek függetlenek egymástól.

A következő fejezetben bemutatom a magyar sajátosságokat, a hipotéziseimet, és az elvégzett vizsgálatokat. 


\section{Az ágazatok térbeli koncentráltságának, illetve agglomeráltságának vizsgálata Magyarországon: a módszertan adaptációja}

Magyar területi adatokra specializálva a nemzetközi szakirodalomban megjelenő módszertant olyan eredményeket várhatunk, amelyek egyrészt tükrözik a magyar sajátosságokat, másrészt a már korábban elvégzett külföldi elemzések eredményeivel összehasonlíthatók.

Mint korábban említettem, vizsgálataim során a gazdasági tevékenységek térbeli koncentrációját és agglomerációját lokális és globális mutatószámokkal egyaránt fel kívántam mérni. Az alkalmazott mutatószámok pedig a térbeli koncentrálódás vizsgálatára az EG $\gamma$ mutató és az LQ index, az agglomeráció esetében pedig a Moran index és a lokális Moran index voltak.

Magyarország mind méretében, mind intézményi és gazdasági struktúrájában jelentős különbségeket mutat a nemzetközi vizsgálatokban szereplő országokhoz képest. Mint azt korábban említettem, a gazdasági tevékenységek koncentrálódásának folyamata eltérő időszakokban ment végbe egyes országokban, a városrobbanás időszakát, az ipari forradalom hatásait a kiegyezéstől kezdve (1867) lehetett érzékelni hazánkban is, azonban olyan erős várrosnövekedési és iparosítási forrásokkal, mint amilyenek a nyugat-európai koncentrálódást jellemezték, nem rendelkeztek (Enyedi 2012).

Magyarországra vonatkozó empirikus vizsgálataim tervezése során a következő néhány fontos tényezőt tartottam szem előtt:

- Magyarország térfelosztási szintjei:

Magyarország NUTS-LAU rendszer szerinti felosztása alapján a kistérségi szint a LAU 1-es osztályozási szintnek felel meg. Térbeli koncentrációs vizsgálataim alapjául ezt a szintet választottam, mert nem kívántam települési szintig (LAU 2) lemenni, hiszen a vizsgált gazdasági tevékenységek sok település esetében nem figyelhetők meg, feltételezésem szerint a térbeli koncentráció vizsgálatának relevanciája csak magasabb szinten jelenik meg. Ezt támasztja alá a nemzetközi szakirodalom is, település szintü vizsgálatokra csak nagy népsűrüségü és magasan fejlett országokban került sor. Véleményem szerint - mivel mind a gazdasági tevékenységek térbeli koncentrációját, mind pedig az agglomerációját fel kívántam mérni - a kistérségi szint megfelelő, mert 
az agglomeráció vizsgálatával a kistérségi határokon túlnyúló centripetális erök meglétét is visgálni lehet, és ez az a szint, amellyel a nemzetközi vizsgálatokban is legtöbb esetben foglalkoztak.

\section{- Azágazatok vizsgálata}

A globális mutatószámok (EG $\gamma$, Moran index) kiszámítása után az ágazatok vizsgálata többféle lehetséges módon történhet. Az ágazatok vizsgálhatók egyenként a különbözö mutatók értékei által rajzolt összetett képet elemezve, ebben az esetben a konkrét ágazatról alkotott kép áll érdeklődésünk fókuszában. Vizsgálhatók az egyes mutatószámok is több ágazat együttesén, például gyakorisági eloszlás elemzése segítségével, ebben az esetben a mutatószámok viselkedését kívánjuk értelmezni attól függően, hogy a kiszámításuk milyen feltételek mellett történt.

\section{- Budapest}

Az elöző pontban említett egyik megváltoztatható feltétel Magyarország esetében az, hogy a mutatószámokat Budapest adatainak figyelembevételével, vagy anélkül számoljuk ki. Módszertani szempontból kiemelendő, hogy a Budapest adatainak elhagyásával számított lokális Moran index értékek részben Budapest szívóhatását is beszámítják, de ma már egyre erösödnek a kapcsolatok a körülvevő kistérségek között is, a korábbi egymagvú, egy központú „hierarhizált nagyvárosi agglomeráció”-ból átalakul „horizontális nagyvárosi régióvá”, amely továbbra is egymagvú, de több alközponttal rendelkezik (Enyedi 2012, 16-17. o.).

- Viszonyítási alap

A foglalkoztatási LQ mutatószámnál említett $E$ és $e_{j}$ értékek kiszámításának módja is egy olyan lehetőség, amely az előző pontban említett megváltoztatható feltétel lehet, tehát attól függően, hogy az nemzetgazdaság egészében foglalkoztatottak vagy pedig a szektoriális foglalkoztatottak térbeli eloszlásához viszonyítunk, más-más eredmény születhet.

\section{- Szomszédsági mátrix}

Ugyancsak az adatok elérhetőségétől függ, hogy az agglomeráció mérésénél felhasznált szomszédsági mátrixot milyen módszerrel állítjuk elő. Erre rendkívül sok lehetőség kínálkozik, lásd például Dusek (2004, 204. o.), Getis és Aldstadt (2004), Anselin (1988). Vizsgálataimat bástya szomszédság feltételezésével végeztem, aminek több oka van. Egyrészt természetesen lehetett volna távolság alapú szomszédsági mátrixot alkalmazni, azonban az a mátrix, amelyet a Geoda 9.5-i program generál, nem közúti 
távolság, vagy elérési idő alapú (ilyen a vizsgálat elvégzésének időpontjában nem állt rendelkezésemre), hanem kizárólag a kistérségek geometriai középpontjai közötti légvonalbeli távolságot használja. Ebben az esetben is meg kellett volna határoznom azt, hogy hány legközelebbi szomszédot használjon ( $k$ nearest neighbours), vagy pedig azt, hogy mekkora maximális távolságot alkalmazzon a program. E paraméterek kiválasztására azonban nem tudtam alapos indokot találni. A légvonalbeli távolságok számítása esetén a valódi térkapcsolatokhoz képest jelentős eltérések lehetnek, így e paraméterek megválasztása nagy körültekintést igényel. Másrészt a lokális Moran index értékek kiszámításának értelmezése bástya szomszédság esetén lényegesen egyszerübben leolvasható a térképekről: az i-edik területi egységgel közös határvonallal rendelkező kistérségek $d_{j}=\left(s_{j}-x_{j}\right)$ értékeinek számtani átlaga megszorozva a $d_{i}=\left(s_{i}-x_{i}\right)$ értékkel. A térképeken pedig ezen értékek szignifikáns voltát jellemezzük.

\subsection{Hipotézisek}

A szakirodalom eredményeinek feldolgozására alapozva, azokat felhasználva és kiegészítve a következő gondolatok és hipotézisek mentén vizsgálódtam.

Magyarországon is megfigyelhető az urbanizációs és lokalizációs előnyök szerinti kistérség típusok elkülönülése, ezen kívül Budapest, mint speciális kistérség különösen kirívó helyzetben van. Nagy szerepe van úgy gazdaságilag, mint kulturálisan és rengeteg egyéb szempontból is. Maga a város - ha nem is a legnagyobb területü - mégis messze a legnagyobb népességü, népsűrüségű és jelentőségű az országban. Bár Budapestnek kétségtelenül meghatározó szerepe van mind társadalmi, mind gazdasági szempontból, azonban statisztikailag mégis torzító körülmény, hogy itt koncentrálódik az intézmények nagy része (például az országos jelentőségű intézmények), amelyek kizárólag Budapest statisztikai adataiban jelennek meg, annak ellenére, hogy az ország többi részét is szolgálják (Lukovics 2008). Az is torzító tényező, hogy akár települési, akár kistérségi vagy megyei szintü a térfelosztás, Budapest mindegyik esetben egyetlen egységként szerepel, holott lakossága Magyarország lakosságának körülbelül 17 százalékát teszi ki, vonzáskörzetével együtt pedig kb. 30\%-át (KSH 2010).

Más európai országokban is vannak olyan pólusok, amelybe a népességnek, gazdaságnak nagy hányada tömörül - Ausztria lakosságának 20\%-a él Bécsben, Csehország lakosságának 12\%-a él Prágában - Eurostat (2012) -, mégis ritka jelenségnek tekinthető. 
Egyes országokban több pólus is található, de a nemzetközi szakirodalomban nem foglalkoznak ezzel a kérdéssel, a magyar területi elemzési vizsgálatokban viszont rendre találkozunk e helyzet kezelésével.

Éppen ezért úgy gondolkodtam, hogy megvizsgálom a mutatószámok értékeit Budapest adatainak figyelembevételével és azok nélkül is, így első hipotézisem:

I. hipotézis: A magyar gazdasági tevékenységek esetében kistérségi szinten jelentős eltérés várható a Budapest adatainak figyelembevételével, illetve ezen adatok nélkül kiszámított értékekben

a. a térbeli koncentráció mérőszámában,

b. az agglomeráció méröszámában.

Az egyes alágazatok mutatószámaiban megjelenő különbségek segítségével pedig következtetni lehet Budapest, mint föváros helyzetére a vizsgált ágazatban.

Az alkalmazott mutatószámok (EG $\gamma$, Moran index, LQ, LISA index) mindegyikében megjelennek az egyes területi egységekhez tartozó $s_{i}$ és $x_{i}$ értékek. Attól függően, hogy az $x_{i}$ hányad

a. a nemzetgazdaság egészében foglalkoztatottaknak,

b/1. az iparban és építöiparban foglalkoztatottaknak,

b/2. a szolgáltatásokban foglalkoztatottaknak

az i-edik területi egységbe eső része, más és más mutatószámértékek adódnak. Az a. esetben mind a szektoriális, mind az ágazat-specifikus centripetális és centrifugális erők hatását számba vesszük, a mutatók ezek eredőjét tükrözik. A b. esetben - amikor az $x_{i}$ értékek alapja az a konkrét, a nemzetgazdaság egészénél szűkebb szektor, amelybe a vizsgált ágazat tartozik -, akkor csak a szektoron belül ható ágazat-specifikus koncentrációs erők következményeit mérjük. E két számítási mód éppen az agglomeráció-koncentráció fogalompárnak a vizsgált gazdasági tevékenységek köre (BGM megközelítés, Brakman és társai 2009) alapján történő megkülönböztetésével hozható összefüggésbe. Ennek megfelelően:

II. hipotézis: Az, hogy a mutatószámok viszonyítási alapját képező foglalkoztatottsági adatok az egész nemzetgazdaságra, vagy csak az ipar és épitöipar szektorára vonatkoznak, szignifikáns különbséget jelent Magyarországon kistérségi szinten:

a. a térbeli koncentráció mérőszámában;

b. az agglomeráció méröszámában.

A nemzetközi szakirodalomban, az elméleti modellekben a tudástúlcsordulás egy rendkívül fontos tényező a gazdasági tevékenységek térbeli sűrüsödésében. Éppen ezért több 
empirikus elemzés is célzottan vizsgálta, hogy azokban az (al-) ágazatokban, amelyekben több tudás termelődik - vagyis a tudásintenzív ágazatokban -, nagyobb mértékü térbeli koncentrálódást várhatunk-e, mint a nem tudásintenzív ágazatok esetében. Éppen ezért fogalmaztam meg a következőt:

III. hipotézis: Magyarországon, kistérségi szinten a tudásintenzív ágazatok esetében várhatóan magasabb mutató értékeket kapunk

a. a térbeli koncentráció,

b. az agglomeráció,

méröszámai esetén, mint a nem tudásintenzív ágazatokéban.

A nemzetközi szakirodalom vizsgálati eredményeiből azt a következtetést vontam le, hogy az ágazatokat/alágazatokat érdemes mind a területi koncentrációt, mind az agglomerációt mérő mutatószámok alapján vizsgálni, mivel ezek együttmozgása és ellentétes irányú mozgása is megjelenhet, miközben a mérni kívánt jelenségek a két esetben különböznek egymástól. Ebből adódik:

IV. hipotézis: Magyarországon, kistérségi szinten a térbeli koncentráció és agglomeráció közötti - Lafourcade és Mion által megfogalmazott - különbségtétel módszertanilag megalapozott, a kétféle fogalom méröszámai alapján létrehozott két dimenzió független.

A magyar gazdaságra vonatkozó emprikus vizsgálatokat e hipotézisek tesztelése mentén végeztem, miközben törekedtem a nemzetközi módszertan lehetőleg széleskörü magyarországi alkalmazására.

\subsection{A magyar adatok elemzése - kiindulópont}

Minden foglalkoztatottsági adatokat felhasználó térbeli koncentrációt mérő mutatószámnál alapvető követelmény, hogy teljesítse a Duranton és Overman (2002) által állított 2. feltételt: az összes gazdasági tevékenység térbeli eloszlásának hatását szürje ki. Vizsgálataim során két különböző viszonyítási alapot használtam - ez azt jelenti, hogy az $s_{i}$ értékek vektorát két különböző $x_{i}$ vektorral vetettem össze -, tehát az a hatás, amelyet a mutatószámok kiszürnek, a két esetben különböző: (a) a nemzetgazdaság egészében foglalkoztatottak, illetve (b) az egyes szektorokban foglalkoztatottak térbeli eloszlásának hatása. Érdemes felmérni ezért azt is, hogy a különbség miben nyilvánul meg. Ennek érdekében minden kistérségre kiszámoltam a Budapest adataival együtt, illetve ezen adatok nélkül is a szektoriális LQ és LISA index értékeket, és térképen ábrázoltam ezeket. A 
kistérségi foglalkoztatási adatok a KSH Területi Statisztikai Évkönyv 2007. kiadványból, illetve a 2001-es népszámlálási adatokból származnak. E számításaim esetében az $s_{i}$ értékek a szektoriális foglalkoztatottak térbeli eloszlását reprezentálják, az $x_{i}$ értékek - amelyekhez viszonyítunk - a nemzetgazdaság egészében foglalkoztatottak térbeli eloszlását jelentik. A felső ábrák a térbeli koncentrációt mutatják, az alsók pedig az agglomerációt.

Az iparban és épitőiparban foglalkoztatottak térbeli eloszlását vizsgálva látható, hogy kilenc olyan kistérség van, amelyekben az LQ index értéke nagyobb, mint 1,5, közülük nyolc a Közép-Dunántúli régióban található (4. ábra). Megállapítható, hogy elsősorban a Közép- és Nyugat-Dunántúli régiók kistérségeiben koncentrálódik és agglomerálódik az ipar és építőipar, itt nagy összefüggő területek hot-spotnak nevezhetők (5. ábra). Ezen kívül még az Észak-Magyarországi régió több kistérségében koncentrálódik az ipar és építőipar, itt agglomerálódásról viszont csak a Hatvani és a Gyöngyösi kistérségek esetében beszélhetünk (hot-spotok). Ezzel szemben Budapesten és a környező kistérségekben, a Ráckevei kistérségtől eltekintve egyértelmủen alulreprezentáltság tapasztalható, Budapest hatásának köszöhetően ezek a kistérségek egyúttal cold-spotok is (4-5. ábra).

Budapest adatait figyelmen kívül hagyva kis mértékben változik a kép (6. és 7. ábra), több olyan kistérség van, amelyben alulreprezentált az ipari és építőipari tevékenység. A Balaton környéki kistérségek ilyenek, Somogy megye, Baranya megye déli területei, a Budapestet körülvevő kistérségek, Bács-Kiskun és Csongrád megye szinte egésze, néhány kistérségtől eltekintve, valamint Borsod-Abaúj-Zemplén és Szabolcs-Szatmár-Bereg megye, amelyek mind a Budapest adataival számított eset területeinek bővülésével jönnek létre. A Budapestet körülvevő kistérségek többé már nem cold spotok, ami igazolja azt, hogy az 5. ábrán Budapest hatására voltak ezek cold-spotok.

A legnagyobb népességü városok kistérségeiben (Szeged, Debrecen, Miskolc, Pécs, Kecskemét, Nyíregyháza) is alulreprezentáltságot tapasztalunk, a 100 ezer fönél több lakossal rendelkező kistérségek közül csak a Győri és a Székesfehérvári kistérségekben (autóipar) láthatunk felülreprezentáltságot ${ }^{28}$, ami koncentráció és agglomeráció formájában jelentkezik, mindkettő hot-spot. Enyhe felülreprezentáltság tapasztalható még Békés megye északnyugati, valamint Jász-Nagykun-Szolnok megye déli kistérségeiben. Továbbra is a Közép-és NyugatDunántúli régiók kistérségeiben koncentrálódik és agglomerálódik az ipar és építőipar, de a terület kiterjedése némileg csökken.

\footnotetext{
${ }^{28}$ A lakónépesség és az ipari LQ értékek között 5\%-os szinten szignifikáns negatív lineáris kapcsolat van, a korrelációs együttható értéke -0,189.
} 
4. ábra: Az iparban és építőiparban foglalkoztatottak eloszlása az nemzetgazdaság egészében foglalkoztatottakhoz képest (LQ értékek) Budapesttel

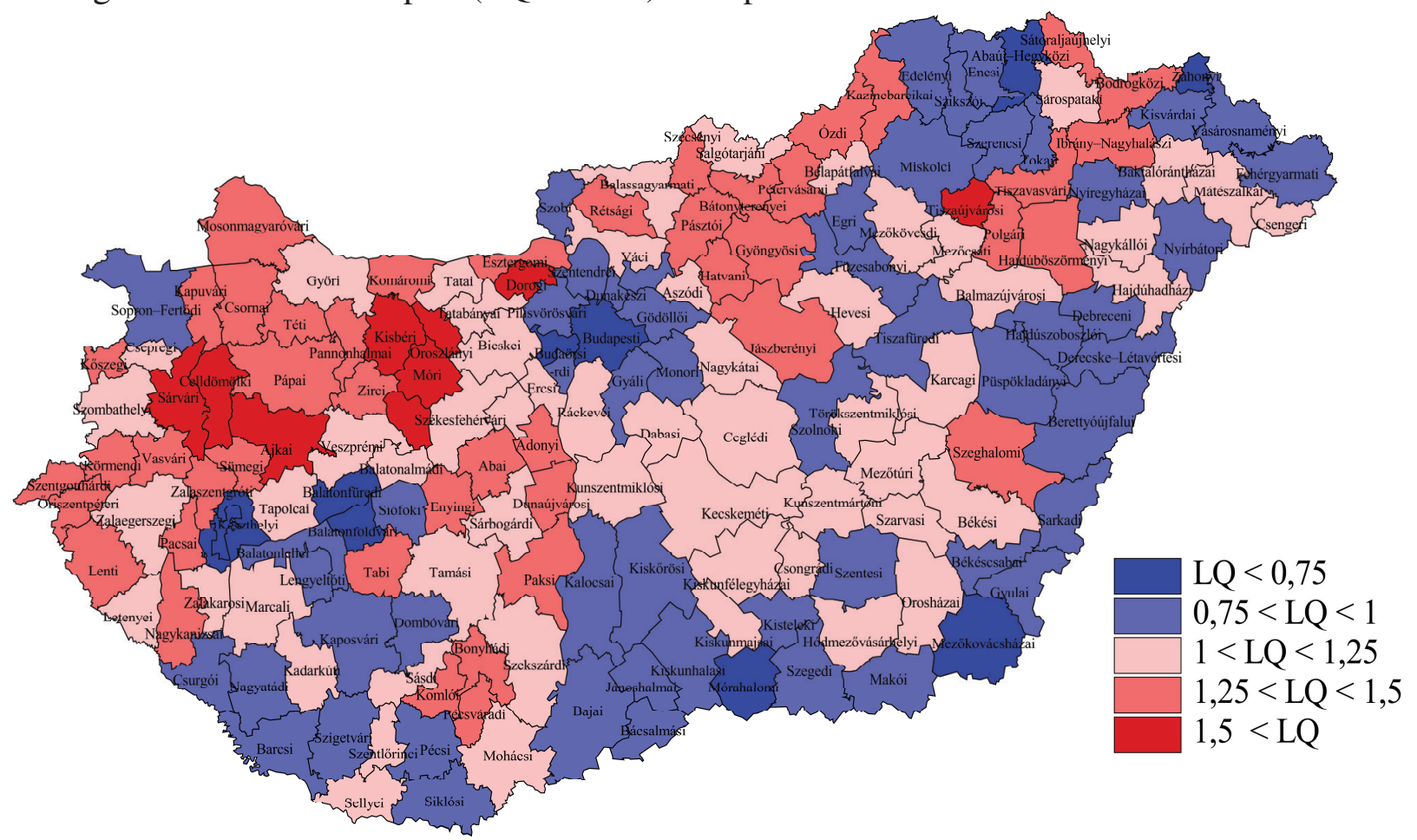

Forrás: saját szerkesztés

5. ábra: Az iparban és építőiparban foglalkoztatottak eloszlásának térbeli autokorrelációja az nemzetgazdaság egészében foglalkoztatottakhoz képest (LISA index értékek alapján) Budapesttel

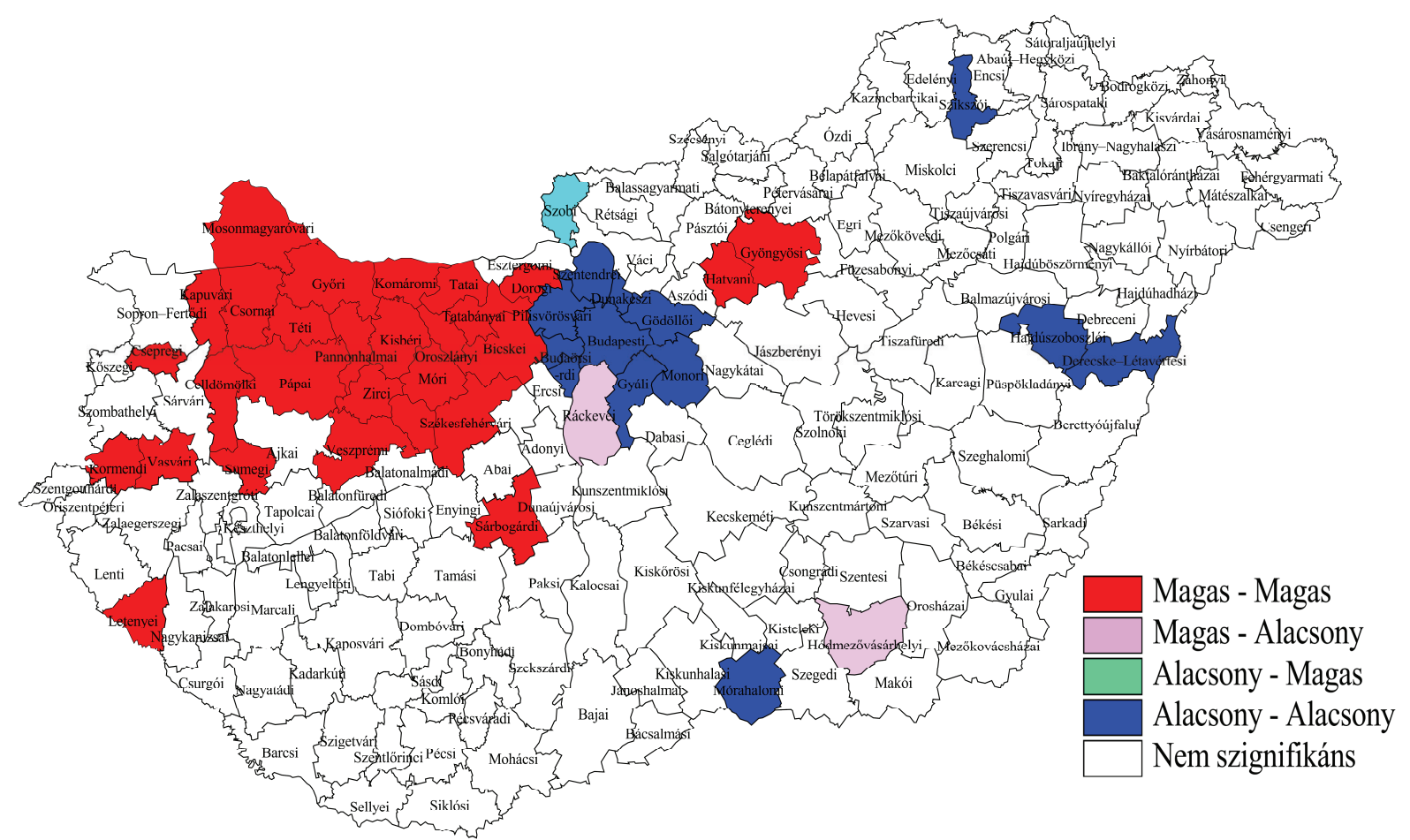

Forrás: saját szerkesztés 
6. ábra: Az iparban és építőiparban foglalkoztatottak eloszlása az nemzetgazdaság egészében foglalkoztatottakhoz képest (LQ értékek) Budapest nélkül

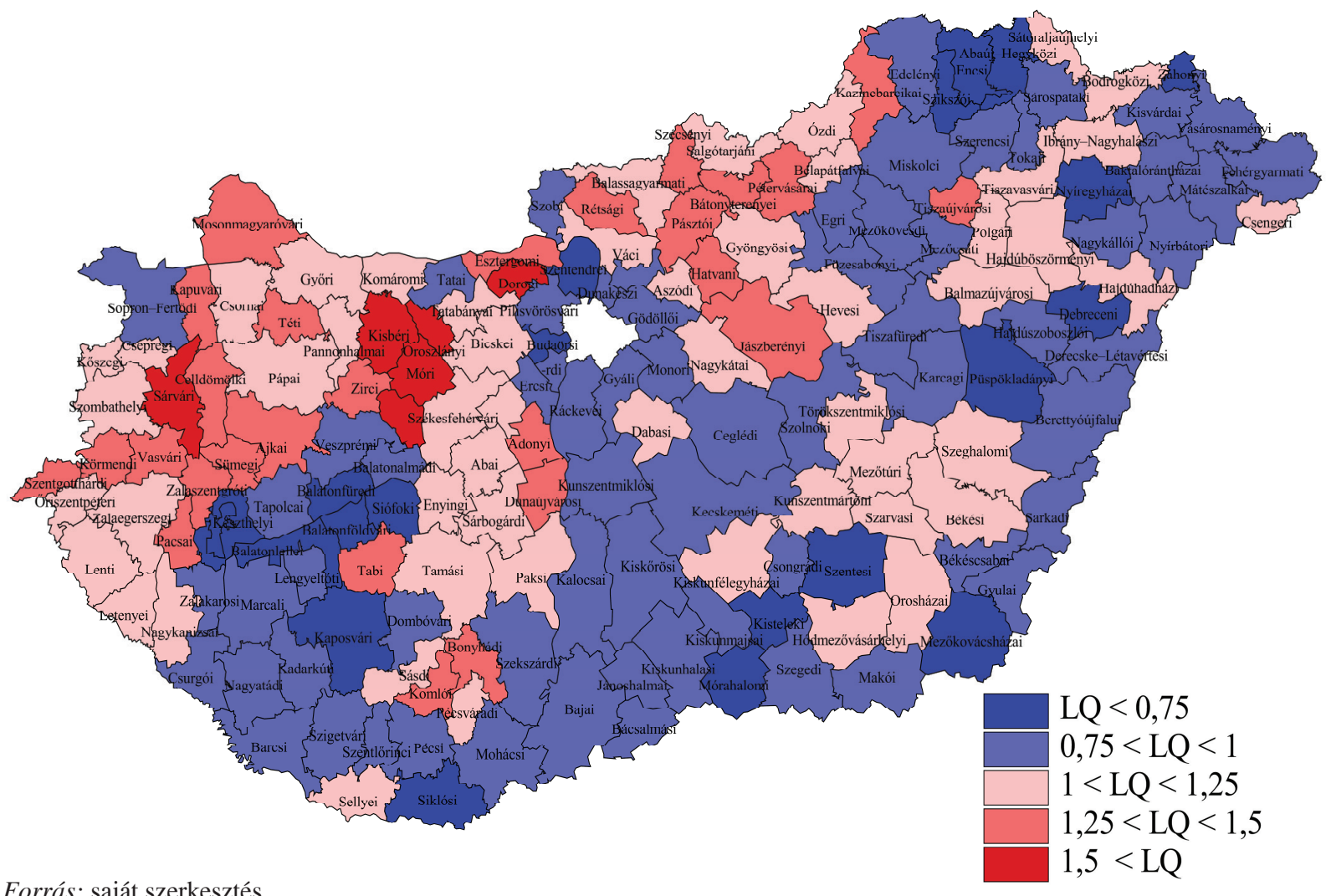

Forrás: saját szerkesztés

7. ábra: Az iparban és építőiparban foglalkoztatottak eloszlása térbeli autokorrelációja az nemzetgazdaság egészében foglalkoztatottakhoz képest (LISA index értékek alapján) Budapest nélkül

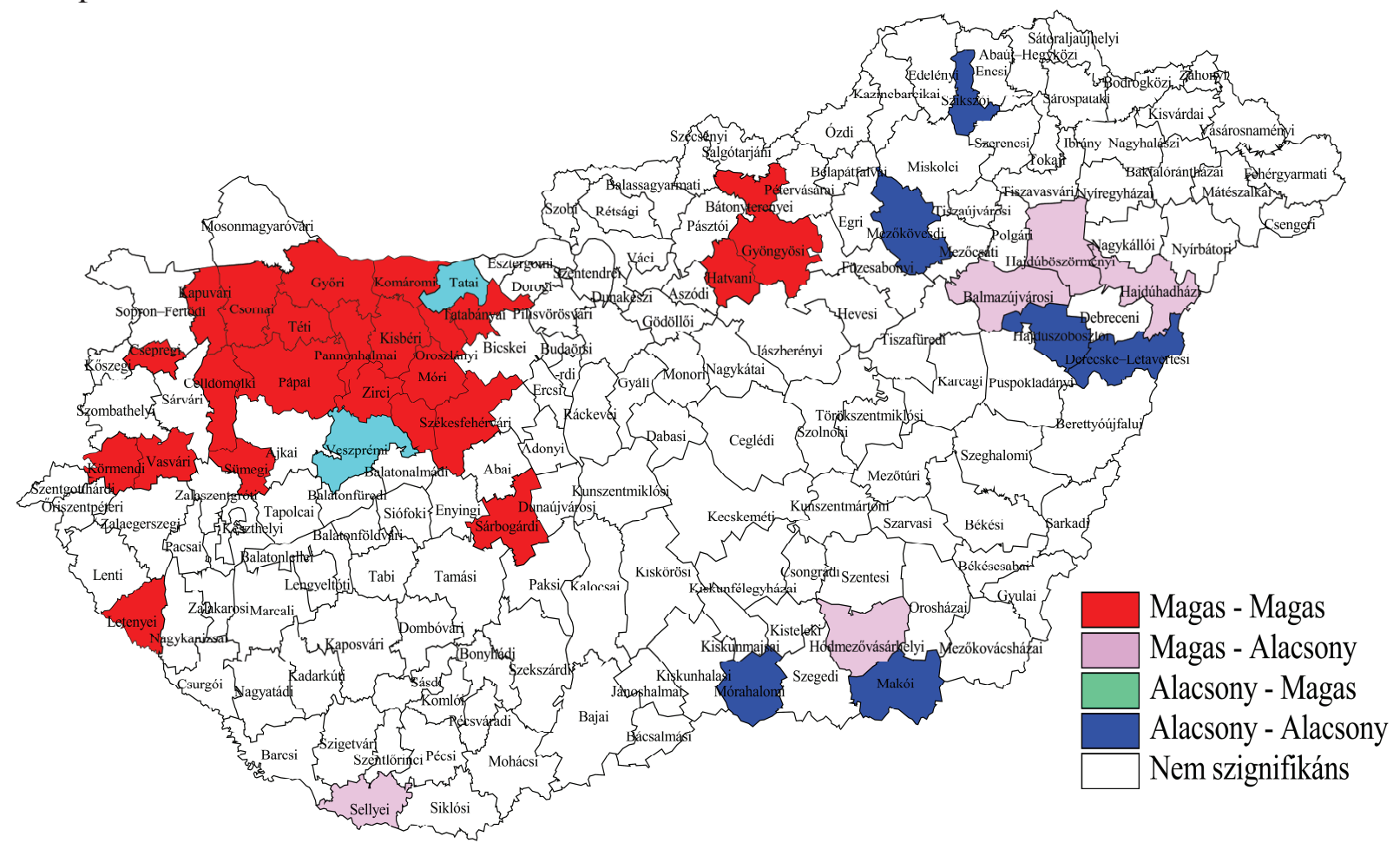

Forrás: saját szerkesztés 
A szolgáltatásokhoz szerkesztett térképeken (8-11. ábra) szinte éppen az előző térképek „negatívjai” láthatók (az ipari és szolgáltatási LQ értékek közötti lineáris korrelációs együttható értéke -0,768, ami nem meglepő annak fényében, hogy a nemzetgazdaság egészében foglalkoztatottak három szektor: a mezőgazdaság, az ipar és építőipar, valamint a szolgáltatások által foglalkoztatottakból tevődnek össze, tehát az adatok valamilyen szinten komplementerei egymásnak). Az elöbb említett legnagyobb népességű városok kistérségeiben mindenhol koncentrálódik a szolgáltatási szektor össz-foglalkoztatottak eloszlásához képest, de az LQ értékek sehol sem lépik túl az 1,5-es határt, és egyik esetében sem agglomerálódik a szolgáltatási szektor, vagyis kistérségi határokon belül marad a koncentrálódás (8-9. ábra).

A Budapesten, és a körülvevő kistérségekben koncentrálódik és agglomerálódik is a szolgáltatásokban megvalósuló foglalkoztatás, e kistérségek mindegyike hot spotnak tekinthető, de a 9. és 11. ábrák összevetéséből kitünik, hogy ez az Érdi és a Dunakeszi kistérségek kivételével elsősorban Budapest szomszédságának köszönhető. A Balaton környékén koncentrálódik még a szolgáltatási szektor, valamint a Miskolci kistérségben, és a tőle északkeletre fekvő Borsod-Abaúj-Zemplén megyei kistérségekben található a vártnál magasabb foglalkoztatás a szolgáltatásokban, és e kistérségek hot-spotnak is tekinthetők: itt agglomerálódásról beszélhetünk feltehetően a turisztikai szolgáltatásoknak köszönhetően.

A Győr-Moson-Sopron, Komárom és Veszprém megye hármas határán lévő kistérségek, amelyek az ipar és építöipar szempontjából hot spotnak számítanak a szolgáltatási szektor esetében éppen cold-spotok, tehát e kistérségekben és szomszédaikban alacsonyabb a szolgáltatásokban való foglalkoztatás.

A Budapest adatai nélkül (10-11. ábra) a szolgáltatások esetében éppen fordított a változás a Budapest adataival együtt számolt értékekhez viszonyítva, mint az ipar építőipar esetén. Itt éppen a koncentrált (specializált) területekből van több, tehát a felülreprezentált területek bővülnek. A Budapestet körülvevő kistérségek már nem mind hot-spotok, de az Edelényi és Szikszói kistérségekben koncentráltan van jelen a szolgáltatási szektor, és a környezetükben agglomerálódik is.

A Győri kistérség már nem cold spot, hanem kiemelkedik a környezetéböl: gyengén felülreprezentált a szolgáltatásokbeli foglalkoztatottság, és a körülötte lévő, korábban említett alulreprezentált területek kiterjedése is kisebb a Budapest adataival számított esethez képest. 
8. ábra: A szolgáltatási szektorban foglalkoztatottak eloszlása az nemzetgazdaság egészében foglalkoztatottakhoz képest (LQ értékek) Budapesttel

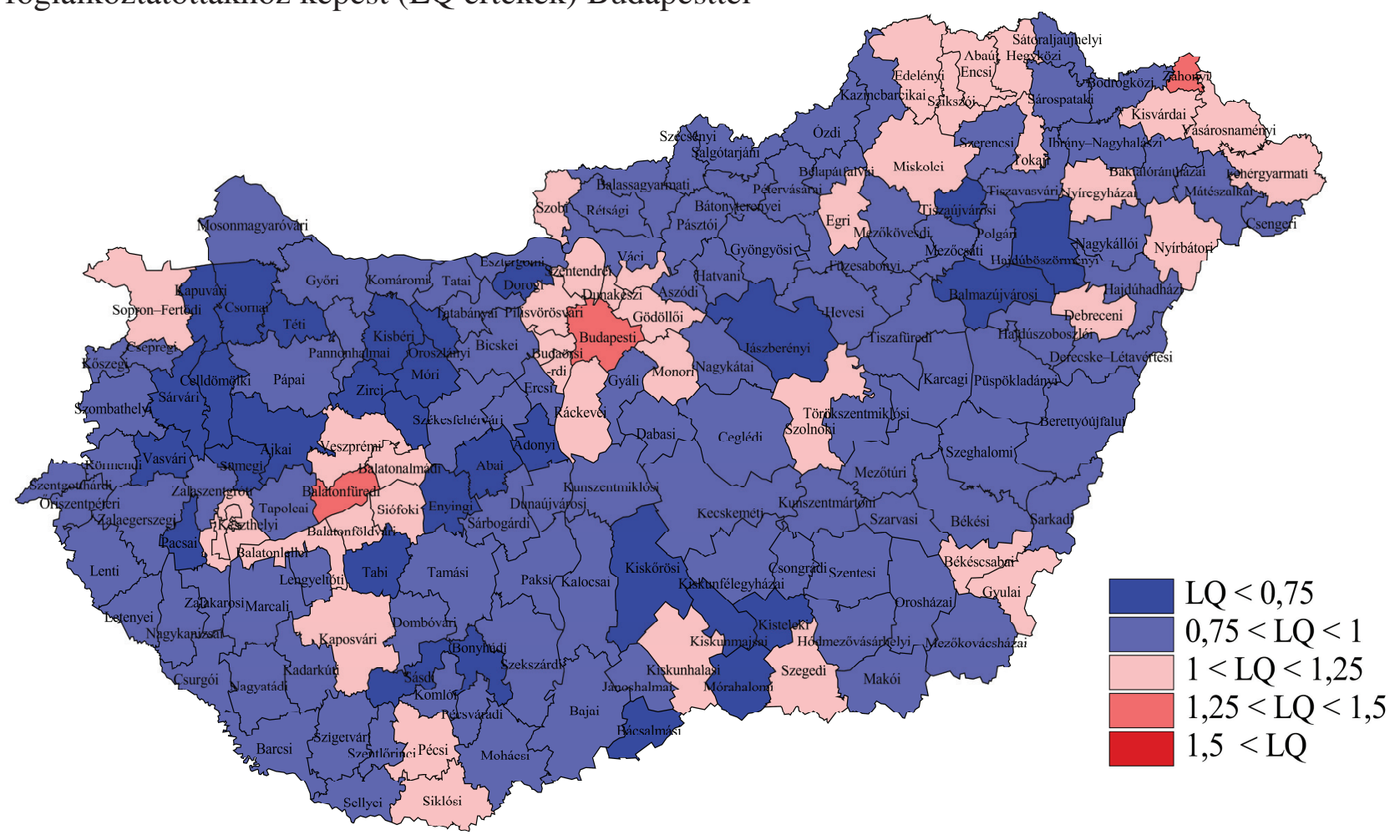

Forrás: saját szerkesztés

9. ábra: A szolgáltatási szektorban foglalkoztatottak eloszlásának térbeli autokorrelációja az nemzetgazdaság egészében foglalkoztatottakhoz képest (LISA index értékek alapján) Budapesttel

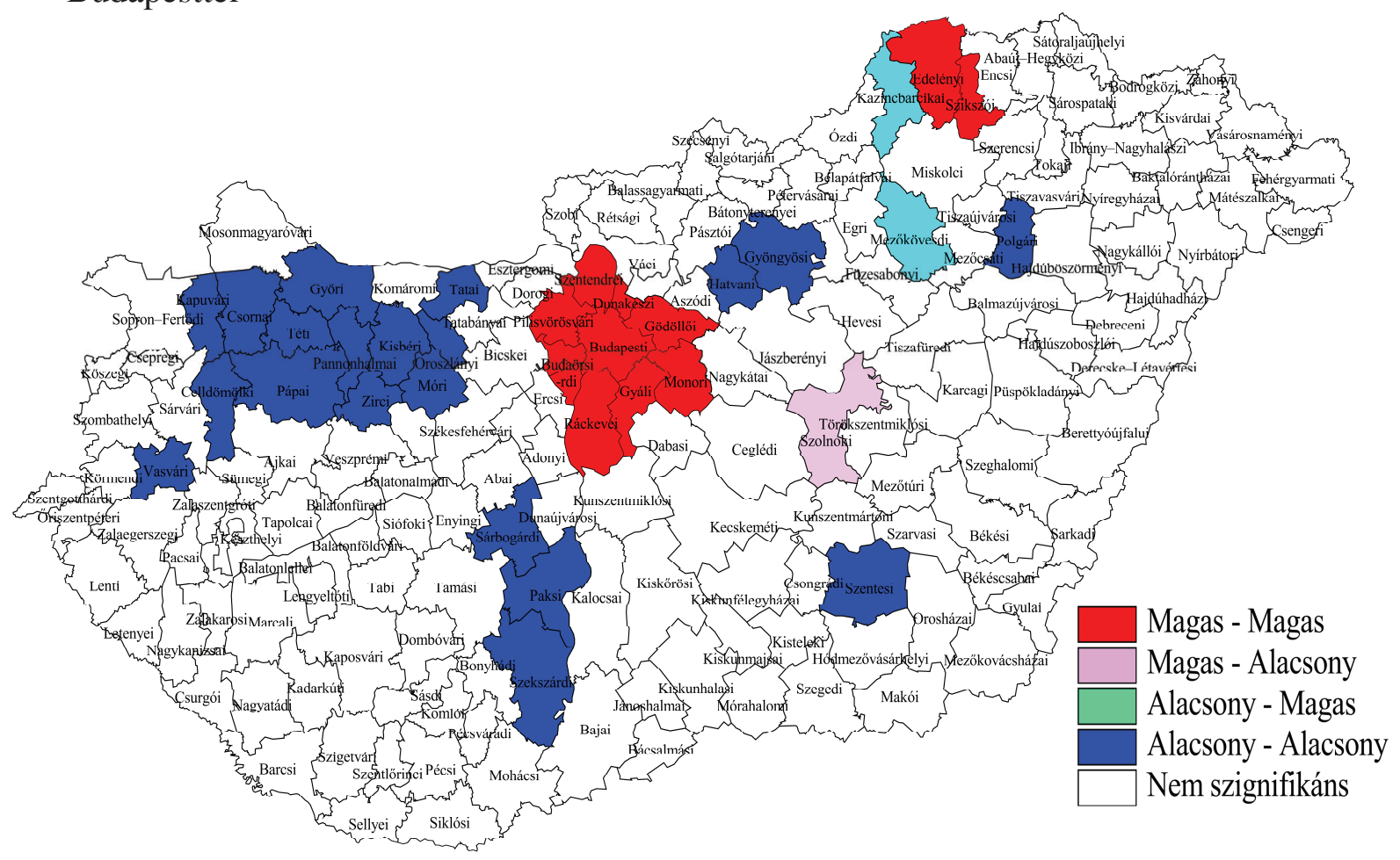

Forrás: saját szerkesztés 
10. ábra: A szolgáltatási szektorban foglalkoztatottak eloszlása az nemzetgazdaság egészében foglalkoztatottakhoz képest (LQ értékek) Budapest nélkül

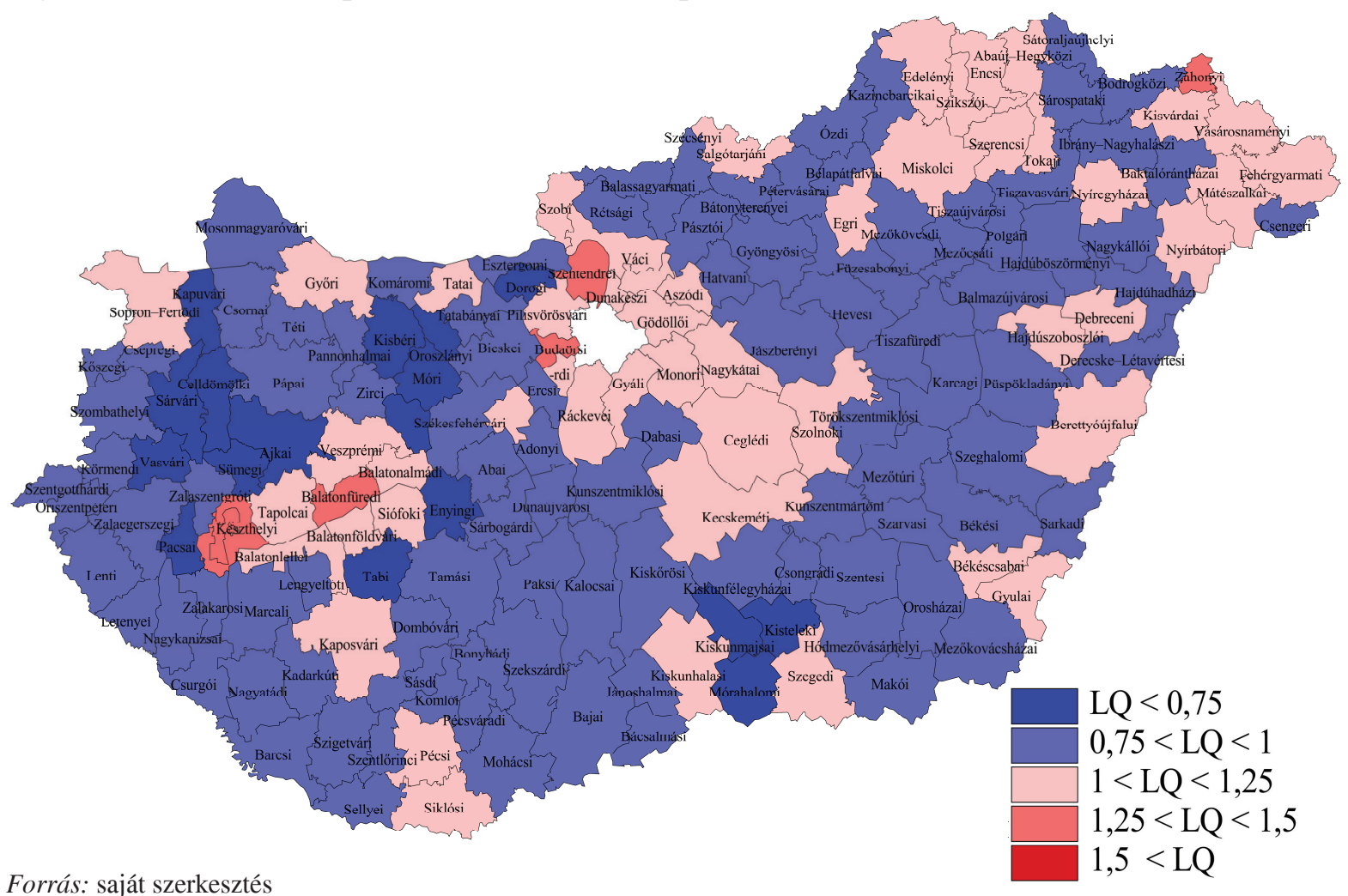

11. ábra: A szolgáltatási szektorban foglalkoztatottak eloszlásának térbeli autokorrelációja az nemzetgazdaság egészében foglalkoztatottakhoz képest (LISA index értékek alapján) Budapest nélkül

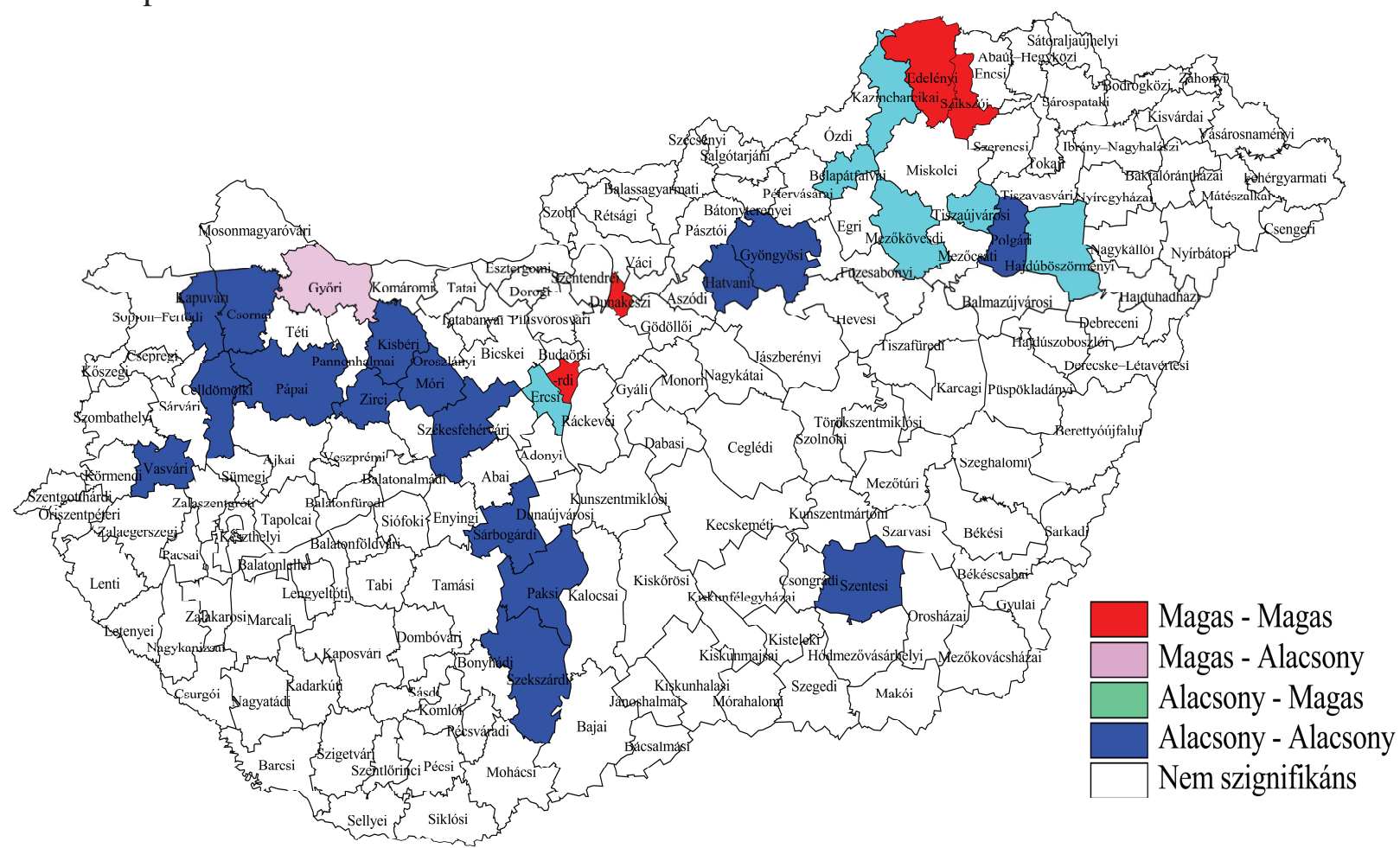

Forrás: saját szerkesztés 
A térképek alapján levonható a következtetés, ha adott esetben feldolgozóipari ágazatot, vagy alágazatot vizsgálunk és összevetjük a nemzetgazdaság egészéhez, illetve az ipar és építőipar szektorához viszonyított térbeli koncentrációs mutató értékeket, a csökkenés annak köszönhető, hogy az (al-)ágazat térbeli eloszlása hasonló az ipar és építőipar térbeli eloszlásához (5. és 7. ábra), például Budapesten és a környező kisrérségekben alulreprezentált. Ha azonban emelkedik a mutató értéke, akkor az adott (al-)ágazat inkább az iparra és építőiparra specializálódott területeken kívül található meg (5. és 7. ábra kék területei), például Budapesten és/vagy környékén.

Ugyanígy, ha szolgáltatási ágazat vizsgálatát végezzük, az EG $\gamma$ mutató esetében a szolgáltatás szektorához viszonyított érték kisebb, mint a nemzetgazdaság egészéhez viszonyított érték, akkor az adott ágazat eloszlása hasonló a szolgáltatási szektor térbeli eloszlásához, például Budapesten és a környező kistérségekben, vagy nagyvárosi kistérségekben található meg. Ha az érték nagyobb, akkor az adott ágazat inkább a szolgáltatásokra specializálódott területeken kívül található meg (9. és 11. ábra kék területei), vagy például sokkal egyenletesebb az eloszlása, mint a szolgáltatásoké.

\subsection{Feldolgozóipar}

Az ipari, köztük is elsősorban a feldolgozóipari ágazatok vizsgálata volt a szakirodalomban az első, ágazatok térbeli eloszlására irányuló vizsgálódási terület. A szolgáltatások, vagy tudásintenzív ágazatok kiemelése és vizsgálata csak később került sorra. Ennek egyrészt az az oka, hogy a térben egyenlőtlen eloszlás az ipari ágazatokban feltünőbb, másrészt pedig az, hogy a MAR, illetve Jacobs-féle externáliák, amelyeket a térbeli koncentrálódás-agglomerálódás hátterében sejtenek a kutatók, az ipar esetében könnyebben értelmezhetők.

Az 3. fejezetben áttekintett vizsgálati lehetőségek közül azokat alkalmaztam a magyar gazdasági tevékenységekre, amelyekhez sikerült megfelelő adatokat beszerezni. Ezen kívül fontos szempont volt a speciális magyar térszerkezet és a korábban már a szakirodalomból megismert, valamint a saját illusztrációs eszközök használata és bemutatása. A hipotéziseim teszteléséhez is ezeket az adatokat tartottam jól felhasználhatónak, mert itt elegendő számú alágazattal dolgozhattam. 


\subsubsection{A felhasznált adatok és a kiszámított mutatóértékek}

Az empirikus elemzésben Magyarország feldolgozóipari ágazatait és alágazatait (TEÁOR'03 felosztása alapján) kistérségenként, a főtevékenységük alapján idetartozó cégek és foglalkoztatottjaik száma alapján vettem figyelembe. A kistérségi foglalkoztatási adatok a KSH Területi Statisztikai Évkönyv 2007. kiadványból, illetve a KSH honlapjáról (www.ksh.hu), a 2001-es népszámlálási adatokból, az egyes vállalatok adatai pedig a KSH Céginformációs adattárának (Cég-Kód-Tár) 2007/2-es kiadványából származtak. Még nem álltak rendelkezésre a legutóbbi kistérségi módosítások alapján számolt adatok (2007-töl 174 kistérség van), ezért a 168 kistérségből indultam ki.

Az egyes társas vállalkozások létszám, telephely és szakágazati (TEÁOR’03. négy számjegy) adatait a megfelelő kistérségekhez hozzárendelve kaptam. A kistérségi szintü foglalkoztatottsági adatokat ágazatonként, illetve alágazatonként (TEÁOR'03. kettő, illetve három számjegy) és létszám-kategóriánként gyüjtöttem ki 43 feldolgozóipari alágazatra (4. táblázat). A TEÁOR is módosult (megjelent a TEÁOR’08), de a vizsgálat időpontjában (2008 nyarán) még nem történt meg teljes körúen a vállalkozások átsorolása, ezért maradtam a régebbi besorolásnál.

A 43 alágazat kiválasztása 103 alágazat közül történt. A kiválasztás szempontja a foglalkoztatottak száma volt, ezen alágazatokban a feldolgozóipari foglalkoztatottak $60 \%$-a dolgozott a vizsgálat időpontjában.

Minden mutatószám kiszámításához pontos vállalati létszámadatokra lett volna szükség, ez azonban nem állt rendelkezésre, így ezeket becsülni kellett. A nemzetközi gyakorlat szerint feltételeztem, hogy a vállalati létszámok a létszám-kategóriákon belül egyenletesen oszlanak el (Ellison-Glaeser 1997), így a Herfindahl-index kiszámításakor minden létszámadatot a saját létszám-kategóriáján belüli értékek számtani átlagával helyettesítettem, az EG $\gamma$ mutatóhoz szükséges számításokat az Excel 2003 szoftver segítségével végeztem el.

A vizsgálatban alkalmazott kistérségi szintű foglalkoztatási adatok, amelyek az iparági számításokhoz viszonyítási alapként szükségesek, a 2001-es népszámlálási adatokból származnak. Ezen adatsor a 2006-os, személyi jövedelemadót fizetők száma kistérségi adatsorral 0,999 korrelációban áll, így az előbbit vettem számításaim alapjául. 
4. táblázat: A vizsgált feldolgozóipari ágazatok (2 jegyü) és alágazatok (3 jegyű)

\begin{tabular}{|c|c|}
\hline \multirow{9}{*}{$\begin{array}{l}\text { DA Élelmiszer, ital, dohány gyártása } \\
\text { 15 Élelmiszer, ital gyártása } \\
\text { 15.1 Húsfeldolgozás } \\
\text { 15.3 Gyümölcs-, zöldségfeldolgozás } \\
\text { 15.5 Tejfeldolgozás } \\
\text { 15.6 Malomipari termék, keményítő } \\
\text { gyártása } \\
\text { 15.8 Egyéb élelmiszer gyártása } \\
\text { 15.9 Italgyártás }\end{array}$} & 28 Fémfeldolgozási termék gyártása \\
\hline & 28.1 Fémszerkezet, épületelem gyártása \\
\hline & 28.2 Fémtartály, fütési kazán, radiátor \\
\hline & gyártása \\
\hline & 28.5 Fém felületkezelése, \\
\hline & megmunkálása \\
\hline & 28.6 Evőeszköz, szerszám, általános \\
\hline & fémáru gyártása \\
\hline & 28.7 Egyéb fémfeldolgozási termék \\
\hline \multicolumn{2}{|l|}{ DB textília, textiláru gyártása } \\
\hline 17 Textília gyártása & DK gép, berendezés gyártása \\
\hline 17.1 Textilszálak fonása & 29 Gép, berendezés gyártása \\
\hline 17.2 Textilszövés & 29.1 Mechanikai erőgép, energiaközlő \\
\hline 17.4 Konfekcionált textiláru gyártása & gyártása \\
\hline (kivéve: ruházat) & 29.2 Egyéb általános rendeltetésü gép \\
\hline 17.6 Kötött, hurkolt kelme gyártása & gyártása \\
\hline \multirow{4}{*}{$\begin{array}{l}\text { DC bőr, bőrtermék, lábbeli gyártása } \\
\text { 19 Bőrkikészítés; táskafélék, szíjazat, } \\
\text { lábbeli gyártása } \\
\text { 19.3 Lábbeligyártás }\end{array}$} & 29.3 Mezőgazdasági gép gyártása \\
\hline & 29.4 Szerszámgépgyártás \\
\hline & 29.5 Egyéb speciális rendeltetésű gép \\
\hline & gyártása \\
\hline \multirow{4}{*}{$\begin{array}{l}\text { DD fafeldolgozás } \\
\text { 20 Fafeldolgozás, fonott áru gyártása } \\
\text { 20.3 Épületasztalos-ipari termék gyártása } \\
\text { 20.5 Egyéb fa-, fonott áru gyártása }\end{array}$} & 29.7 Máshova nem sorolt háztartási \\
\hline & készülék gyártása \\
\hline & DL villamos gép, műszer gyártása \\
\hline & 30 Iroda-, számítógépgyártás \\
\hline \multirow{2}{*}{$\begin{array}{l}\text { DE papírgyártás, kiadói, nyomdai } \\
\text { tevékenvség }\end{array}$} & 30.0 Iroda-, számítógépgyártás \\
\hline & 31 Máshova nem sorolt villamos gép \\
\hline 21 Papír, papírtermék gyártása & gyártása \\
\hline 21.2 Papírtermék gyártása & 31.1 Villamos motor, áramfejlesztő \\
\hline 22 Kiadói, nyomdai, egyéb & gyártása \\
\hline sokszorosítási tevékenység & 31.5 Világítóeszköz gyártása \\
\hline 22.1 Kiadói tevékenység & 31.6 Egyéb villamos termék gyártása \\
\hline DG vegyi anyag, termék gyártása & 32 Híradás-technikai termék, \\
\hline 24 Vegyi anyag, termék gyártása & készülék gyártása \\
\hline 24.1 Vegyi alapanyag gyártása & 32.1 Elektronikai alkatrész gyártása \\
\hline 24.4 Gyógyszergyártás & 32.2 Ipari híradás-technikai termék \\
\hline 24.5 Tisztítószer, testápolási cikk gyártása & gyártása \\
\hline DH gumi-, műanyag termék gyártása & 32.3 Híradás-technikai fogyasztási cikk \\
\hline 25 Gumi-, múanyag termék gyártása & gyártása \\
\hline 25.1 Gumitermék gyártása & 33 Müszergyártás \\
\hline 25.2 Műanyag termék gyártása & 33.1 Orvosi müszer gyártása \\
\hline DI nemfém ásványi termék gyártása & 34 Közúti jármü gyártása \\
\hline 26 Nemfém ásványi termék gyártása & 34.1 Közúti gépjármü gyártása \\
\hline 26.2 Kerámiatermék gyártása (kivéve: & 34.3 Közúti gépjármü, gépjármümotor \\
\hline $\begin{array}{l}\text { epites1) } \\
26.4 \text { Égetett agyag építőanyag gyártása }\end{array}$ & \\
\hline
\end{tabular}


A Moran-index számításához szükséges kistérségi szomszédsági mátrix adatait a 168 kistérség térbeli elhelyezkedése alapján „bástya” szomszédság alapján állítottam össze, vagyis ha az $i$-edik és $j$-edik területi egységek közös határvonallal rendelkeznek, akkor $w_{i j}$ értéke $1 / n_{i}$ (itt $n_{i}$ az $i$-edik területi egység szomszédainak számát jelöli), különben 0 , valamint $w_{i i}$ is 0 értéket kapott. A Moran index, a p-értékek és a LISA indexek kiszámítása a Geoda 0.9.5-i szoftver segítségével történt, a térképek ábrázolásához pedig az ArcView 3.2 szoftvert használtam. A Moran index értelmezésénél megadott képlet szerint a várható érték a 168 kistérség esetén $-\frac{1}{M-1}=-0,005988$, a Budapest adatai nélküli számításokban pedig ez az érték $-\frac{1}{M-1}=-0,006024$.

Mindegyik, felsorolt feldolgozóipari alágazat esetében meghatároztam a térbeli koncentrálódás (EG $\gamma$ ) és az agglomerálódás (Moran-index) mutatószámokat különböző esetekre (5. és 6. táblázat).

A vizsgált alágazatok közül a térben leginkább koncentrált alágazat az alapértelmezés szerinti számítás esetén - vagyis ha az iparban és építőiparban foglalkoztatottak számához képest, Budapest adatainak figyelembevételével mérjük - a 24.4 Gyógyszergyártás rendkívül magas, EG $\gamma=0,34$ értékkel, amelyet a 24.5 Tisztítószer, testápolási cikk gyártása, és a 22.1 Kiadói tevékenység alágazatok követnek.

Ezeknek az alágazatoknak azonban egyike sem nevezhető agglomeráltnak, hiszen Moran index értékeik alapján térben nem autokorreláltak, ahogy az összes többi térben erősen koncentráltnak nevezhető alágazat sem. Ezen alágazatok esetében tehát levonható az a következtetés, hogy azok az erők, amelyek a vállalatokat egymás közelébe vonzzák, léteznek, de nem nyúlnak túl a kistérségi határokon.

Szignifikánsan magas Moran-index értékkel az alapértelmezés szerint mérve a 25.2 Müanyag termék gyártása alágazat rendelkezik, amely még 0,5 százalékos szignifikancia szinten is számottevő. Ez az alágazat viszont térben nem koncentrált, ami annak az eredménye, hogy különösen sok olyan szomszédos kistérség van, amelyekben egyformán relatíve kevés az alkalmazott, és ezek többnyire szomszédosak.

Kiemelendő, hogy ebben az esetben a pozitív térbeli autokorreláltság nem esik egybe az agglomeráltsággal. Az ellentétes irány viszont nem érvényes, vagyis ha kevés vállalat van, ezek néhány kistérségbe települnek, és koncentrált az alágazat sok „üres” kistérséggel, az nem fog magas pozitív autokorrelációt eredményezni, lásd például a 24.4 Gyógyszergyártás alágazatot, amelynek Moran index értéke nem szignifikáns. 
5. táblázat: A vizsgált 43 feldolgozóipari alágazat térbeli koncentráltsága az EllisonGlaeser $\gamma$ mutató értékek alapján.

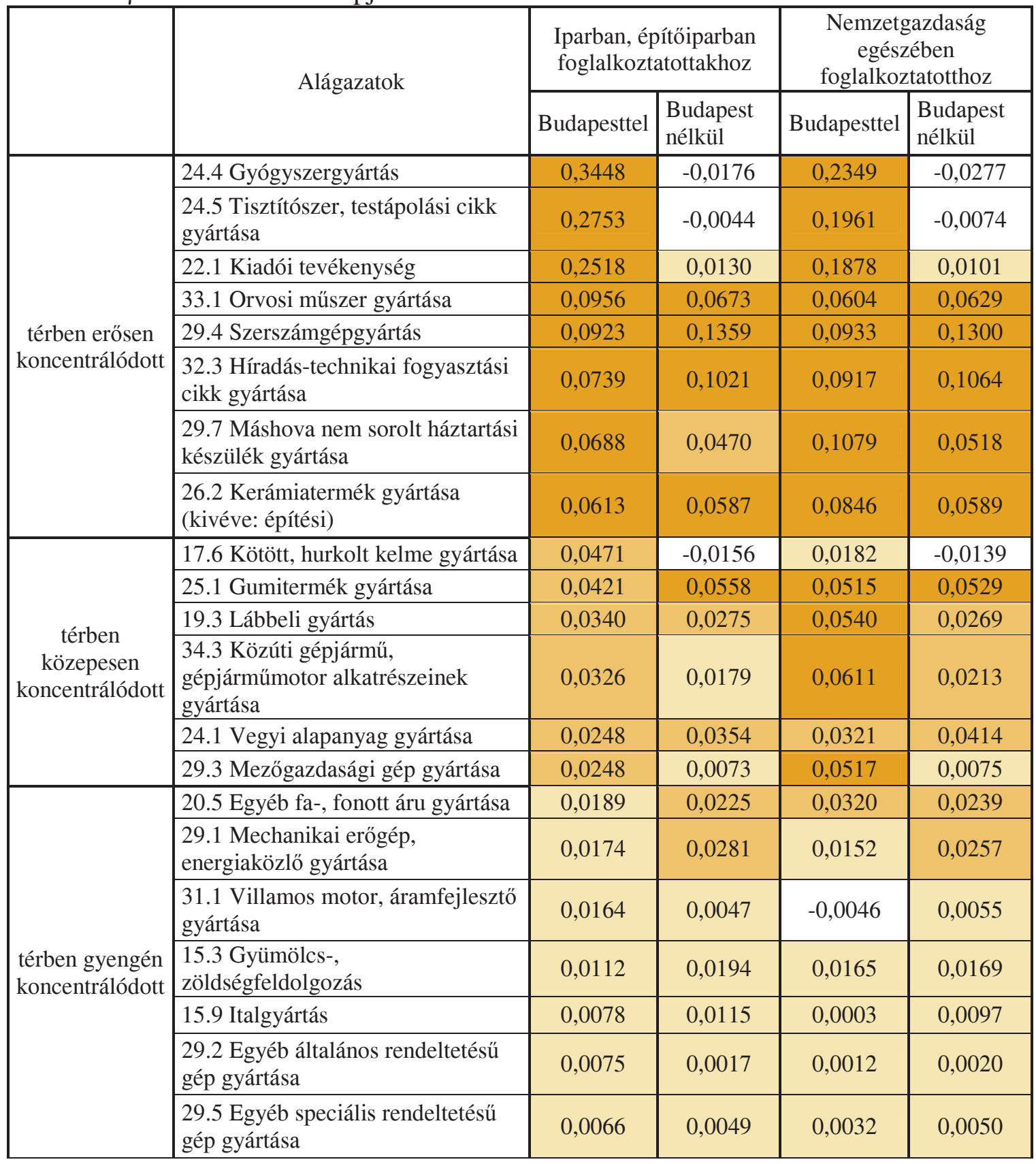

Folytatás a következő oldalon!

Forrás: saját számítások Excel 2003-ban.

Megjegyzés: az ágazatok sorba rendezése az iparban és építőiparban foglalkoztatottak számához képest, Budapest adatainak figyelembevételével mért EG $\gamma$ mutató értékek alapján történt.

Magyarázat: $\square$-térben erősen koncentrálódott; $\square$ - térben közepesen koncentrálódott; $\square$ - térben gyengén koncentrálódott: $\square$ - térben szétszórt. 


\begin{tabular}{|c|c|c|c|c|c|}
\hline & \multirow[t]{2}{*}{ Alágazatok } & \multicolumn{2}{|c|}{$\begin{array}{l}\text { Iparban, építőiparban } \\
\text { foglalkoztatottakhoz }\end{array}$} & \multicolumn{2}{|c|}{$\begin{array}{l}\text { Nemzetgazdaság } \\
\text { egészében } \\
\text { foglalkoztatotthoz }\end{array}$} \\
\hline & & Budapesttel & $\begin{array}{c}\text { Budapest } \\
\text { nélkül }\end{array}$ & Budapesttel & $\begin{array}{c}\text { Budapest } \\
\text { nélkül }\end{array}$ \\
\hline \multirow{11}{*}{$\begin{array}{l}\text { térben gyengén } \\
\text { koncentrálódott }\end{array}$} & $\begin{array}{l}\text { 28.6 Evőeszköz, szerszám, } \\
\text { általános fémáru gyártása }\end{array}$ & 0,0044 & 0,0062 & 0,0032 & 0,0058 \\
\hline & 15.1 Húsfeldolgozás & 0,0044 & 0,0048 & 0,0152 & 0,0039 \\
\hline & 21.2 Papírtermék gyártása & 0,0032 & $-0,0057$ & $-0,0134$ & $-0,0099$ \\
\hline & 34.1 Közúti gépjármü gyártása & 0,0030 & 0,0106 & 0,0482 & 0,0299 \\
\hline & 25.2 Múanyag termék gyártása & 0,0026 & 0,0036 & 0,0088 & 0,0041 \\
\hline & 30.0 Iroda-, számítógépgyártás & 0,0025 & $-0,0034$ & 0,0033 & 0,0004 \\
\hline & $\begin{array}{l}20.3 \text { Épületasztalos-ipari termék } \\
\text { gyártása }\end{array}$ & 0,0023 & 0,0072 & $-0,0005$ & 0,0066 \\
\hline & 15.8 Egyéb élelmiszer gyártása & 0,0022 & 0,0044 & 0,0039 & 0,0032 \\
\hline & 32.1 Elektronikai alkatrész gyártása & 0,0020 & 0,0045 & $-0,0070$ & 0,0066 \\
\hline & $\begin{array}{l}\text { 28.1 Fémszerkezet, épületelem } \\
\text { gyártása }\end{array}$ & 0,0017 & 0,0016 & 0,0022 & 0,0012 \\
\hline & $\begin{array}{l}\text { 28.5 Fém felületkezelése, } \\
\text { megmunkálása }\end{array}$ & 0,0011 & 0,0014 & 0,0045 & 0,0020 \\
\hline \multirow{11}{*}{ térben szétszórt } & $\begin{array}{l}\text { 32.2 Ipari híradás-technikai termék } \\
\text { gyártása }\end{array}$ & $-0,0006$ & $-0,0070$ & 0,0121 & $-0,0026$ \\
\hline & $\begin{array}{l}28.7 \text { Egyéb fémfeldolgozási termék } \\
\text { gyártása }\end{array}$ & $-0,0008$ & $-0,0003$ & 0,0042 & 0,0000 \\
\hline & $\begin{array}{l}28.2 \text { Fémtartály, fütési kazán, } \\
\text { radiátor gyártása }\end{array}$ & $-0,0025$ & 0,0003 & $-0,0103$ & 0,0005 \\
\hline & $\begin{array}{l}\text { 17.4 Konfekcionált textiláru } \\
\text { gyártása (kivéve: ruházat) }\end{array}$ & $-0,0035$ & $-0,0021$ & $-0,0002$ & $-0,0016$ \\
\hline & $\begin{array}{l}\text { 31.6 Egyéb villamos termék } \\
\text { gyártása }\end{array}$ & $-0,0050$ & $-0,0094$ & 0,0106 & $-0,0094$ \\
\hline & $\begin{array}{l}\text { 15.6 Malomipari termék, } \\
\text { keményítő gyártása }\end{array}$ & $-0,0092$ & $-0,0007$ & $-0,0065$ & $-0,0010$ \\
\hline & 15.5 Tejfeldolgozás & $-0,0146$ & $-0,0164$ & $-0,0066$ & $-0,0210$ \\
\hline & 17.2 Textilszövés & $-0,0242$ & $-0,0017$ & $-0,0187$ & 0,0006 \\
\hline & $\begin{array}{l}\text { 26.4 Égetett agyag építőanyag } \\
\text { gyártása }\end{array}$ & $-0,0598$ & 0,0027 & $-0,0797$ & 0,0037 \\
\hline & 31.5 Világítóeszköz gyártása & $-0,0710$ & 0,0076 & $-0,1554$ & 0,0102 \\
\hline & 17.1 Textilszálak fonása & $-0,1500$ & 0,0181 & $-0,2409$ & 0,0219 \\
\hline
\end{tabular}

Forrás: saját számítások Excel 2003-ban

Megjegyzés: az ágazatok sorba rendezése az iparban és építőiparban foglalkoztatottak számához képest, Budapest adatainak figyelembevételével mért EG $\gamma$ mutató értékek alapján történt.

Magyarázat: $\square$-térben erösen koncentrálódott; $\square$ - térben közepesen koncentrálódott; $\square$ - térben gyengén koncentrálódott: $\square$ - térben szétszórt. 
6. táblázat: A vizsgált 43 feldolgozóipari alágazat agglomeráltsága Moran index értékek alapján.

\begin{tabular}{|c|c|c|c|c|c|c|c|c|}
\hline & \multicolumn{4}{|c|}{$\begin{array}{l}\text { Iparban, építőiparban } \\
\text { foglalkoztatottakhoz }\end{array}$} & \multicolumn{4}{|c|}{$\begin{array}{c}\text { Nemzetgazdaság egészében } \\
\text { foglalkoztatotthoz }\end{array}$} \\
\hline & \multicolumn{2}{|c|}{ Budapesttel } & \multicolumn{2}{|c|}{$\begin{array}{l}\text { Budapest } \\
\text { nélkül }\end{array}$} & \multicolumn{2}{|c|}{ Budapesttel } & \multicolumn{2}{|c|}{$\begin{array}{c}\text { Budapest } \\
\text { nélkül }\end{array}$} \\
\hline & Moran I & \begin{tabular}{|c|}
$\mathrm{p}-$ \\
érték
\end{tabular} & Moran I & \begin{tabular}{|c|}
$\mathrm{p}-$ \\
érték
\end{tabular} & Moran I & $\begin{array}{c}\mathrm{p}- \\
\text { érték }\end{array}$ & $\begin{array}{l}\text { Moran } \\
\text { I }\end{array}$ & $\begin{array}{c}\mathrm{p}- \\
\text { érték }\end{array}$ \\
\hline $\begin{array}{l}\text { 25.2 Mủanyag termék } \\
\text { gyártása }\end{array}$ & 0,1358 & 0,005 & 0,1364 & 0,005 & 0,0699 & 0,03 & 0,1631 & 0,002 \\
\hline 19.3 Lábbeli gyártás & 0,0879 & 0,028 & 0,0652 & 0,063 & 0,0898 & 0,012 & 0,0609 & 0,07 \\
\hline $\begin{array}{l}34.3 \text { Közúti gépjármü, } \\
\text { gépjármümotor } \\
\text { alkatrészeinek gyártása }\end{array}$ & 0,0737 & 0,032 & 0,0767 & 0,034 & 0,0759 & 0,02 & 0,0937 & 0,025 \\
\hline $\begin{array}{l}\text { 29.3 Mezőgazdasági gép } \\
\text { gyártása }\end{array}$ & 0,0679 & 0,045 & 0,0401 & 0,13 & 0,0674 & 0,025 & 0,0309 & 0,17 \\
\hline $\begin{array}{l}29.2 \text { Egyéb általános } \\
\text { rendeltetésü gép gyártása }\end{array}$ & 0,0745 & 0,055 & 0,0211 & 0,25 & 0,0354 & 0,17 & 0,0293 & 0,2 \\
\hline $\begin{array}{l}\text { 28.5 Fém felületkezelése, } \\
\text { megmunkálása }\end{array}$ & 0,0702 & 0,056 & 0,0377 & 0,17 & $-0,0282$ & 0,28 & 0,0396 & 0,17 \\
\hline $\begin{array}{l}29.5 \text { Egyéb speciális } \\
\text { rendeltetésű gép gyártása }\end{array}$ & 0,0735 & 0,057 & 0,0199 & 0,22 & 0,0119 & 0,275 & 0,0198 & 0,22 \\
\hline $\begin{array}{l}28.1 \text { Fémszerkezet, } \\
\text { épületelem gyártása }\end{array}$ & 0,0564 & 0,095 & 0,0344 & 0,19 & $-0,0004$ & 0,46 & 0,0127 & 0,33 \\
\hline 31.5 Világítóeszköz gyártása & 0,0164 & 0,097 & $-0,0144$ & 0,45 & 0,0133 & 0,12 & $-0,015$ & 0,47 \\
\hline 25.1 Gumitermék gyártása & 0,0316 & 0,11 & 0,0298 & 0,11 & 0,0393 & 0,09 & 0,0283 & 0,115 \\
\hline $\begin{array}{l}\text { 15.8 Egyéb élelmiszer } \\
\text { gyártása }\end{array}$ & 0,028 & 0,13 & 0,0165 & 0,175 & $-0,005$ & 0,46 & 0,0138 & 0,19 \\
\hline 21.2 Papírtermék gyártása & 0,0213 & 0,15 & $-0,0218$ & 0,35 & 0,0006 & 0,31 & $-0,023$ & 0,32 \\
\hline $\begin{array}{l}28.7 \text { Egyéb fémfeldolgozási } \\
\text { termék gyártása }\end{array}$ & 0,0387 & 0,16 & 0,038 & 0,165 & 0,039 & 0,155 & 0,0448 & 0,14 \\
\hline $\begin{array}{l}\text { 15.3 Gyümölcs-, } \\
\text { zöldségfeldolgozás }\end{array}$ & 0,0346 & 0,16 & 0,0358 & 0,16 & 0,024 & 0,22 & 0,0259 & 0,21 \\
\hline $\begin{array}{l}20.3 \text { Épületasztalos-ipari } \\
\text { termék gyártása }\end{array}$ & 0,0281 & 0,16 & 0,0044 & 0,33 & $-0,0053$ & 0,42 & 0,0017 & 0,35 \\
\hline $\begin{array}{l}17.6 \text { Kötött, hurkolt kelme } \\
\text { gyártása }\end{array}$ & 0,0232 & 0,16 & $-0,0382$ & 0,2 & 0,0138 & 0,23 & $-0,0347$ & 0,25 \\
\hline 22.1 Kiadói tevékenység & $-0,0009$ & 0,16 & $-0,035$ & 0,24 & $-0,0057$ & 0,35 & $-0,0246$ & 0,39 \\
\hline $\begin{array}{l}\text { 17.4 Konfekcionált textiláru } \\
\text { gyártása (kivéve: ruházat) }\end{array}$ & 0,0331 & 0,18 & 0,0471 & 0,12 & 0,0783 & 0,035 & 0,0515 & 0,101 \\
\hline 15.9 Italgyártás & 0,0308 & 0,18 & $-0,0016$ & 0,38 & 0,0041 & 0,34 & $-0,0041$ & 0,41 \\
\hline 29.4 Szerszámgépgyártás & 0,0052 & 0,2 & 0,007 & 0,17 & 0,0116 & 0,13 & 0,0094 & 0,15 \\
\hline
\end{tabular}

Folytatás a következő oldalon!

Forrás: saját számítások Excel 2003-ban és Geoda 0.9.5-i szoftverrel.

Megjegyzés: az ágazatok sorba rendezése az iparban és építőiparban foglalkoztatottak számához képest, Budapest adatainak figyelembevételével mért Moran index értékek alapján történt.

Magyarázat: $\square$ - erősen pozitívan autokorrelált; $\square$-gyengén pozitívan autokorrelált: $\square$ - nem autokorrelált; - gyengén negatívan autokorrelált: $\square$ - erősen negatívan autokorrelált 


\begin{tabular}{|c|c|c|c|c|c|c|c|c|}
\hline & \multicolumn{4}{|c|}{$\begin{array}{l}\text { Iparban, építőiparban } \\
\text { foglalkoztatottakhoz }\end{array}$} & \multicolumn{4}{|c|}{$\begin{array}{l}\text { Nemzetgazdaság egészében } \\
\text { foglalkoztatotthoz }\end{array}$} \\
\hline & \multicolumn{2}{|c|}{ Budapesttel } & \multicolumn{2}{|c|}{ Budapest nélkül } & \multicolumn{2}{|c|}{ Budapesttel } & \multicolumn{2}{|c|}{ Budapest nélkül } \\
\hline & Moran I & $\begin{array}{l}\mathrm{p}- \\
\text { érték }\end{array}$ & Moran I & $\begin{array}{l}\mathrm{p} \text { - } \\
\text { érték }\end{array}$ & Moran I & $\begin{array}{l}\mathrm{p} \text { - } \\
\text { érték }\end{array}$ & Moran I & $\begin{array}{l}\mathrm{p}- \\
\text { érték }\end{array}$ \\
\hline 15.1 Húsfeldolgozás & 0,0187 & 0,228 & 0,0076 & 0,3 & 0,0375 & 0,118 & 0,0039 & 0,33 \\
\hline 17.2 Textilszövés & 0,0012 & 0,3 & 0,0079 & 0,24 & 0,02 & 0,17 & 0,0127 & 0,21 \\
\hline $\begin{array}{l}\text { 32.1 Elektronikai alkatrész } \\
\text { gyártása }\end{array}$ & $-0,0029$ & 0,36 & 0,0058 & 0,28 & 0,0001 & 0,34 & 0,0073 & 0,27 \\
\hline $\begin{array}{l}\text { 29.1 Mechanikai erőgép, } \\
\text { energiaközlő gyártása }\end{array}$ & $-0,0137$ & 0,46 & $-0,0095$ & 0,405 & $-0,0048$ & 0,35 & $-0,0078$ & 0,38 \\
\hline $\begin{array}{l}\text { 28.6 Evőeszköz, szerszám, } \\
\text { általános fémáru gyártása }\end{array}$ & $-0,0173$ & 0,44 & $-0,0354$ & 0,26 & $-0,0271$ & 0,34 & $-0,0221$ & 0,39 \\
\hline 34.1 Közúti gépjármü gyártása & $-0,0072$ & 0,42 & $-0,0068$ & 0,45 & $-0,0029$ & 0,33 & $-0,0056$ & 0,49 \\
\hline $\begin{array}{l}32.3 \text { Híradás-technikai } \\
\text { fogyasztási cikk gyártása }\end{array}$ & $-0,02$ & 0,36 & $-0,0201$ & 0,35 & $-0,0174$ & 0,35 & $-0,0184$ & 0,4 \\
\hline 24.4 Gyógyszergyártás & $-0,0094$ & 0,33 & 0,0159 & 0,098 & $-0,0142$ & 0,15 & 0,0147 & 0,099 \\
\hline 30.0 Iroda-, számítógépgyártás & $-0,007$ & 0,31 & $-0,0034$ & 0,24 & 0,0015 & 0,18 & 0,0012 & 0,18 \\
\hline $\begin{array}{l}26.2 \text { Kerámiatermék gyártása } \\
\text { (kivéve: építési) }\end{array}$ & $-0,024$ & 0,29 & $-0,008$ & 0,35 & $-0,0331$ & 0,13 & $-0,0106$ & 0,39 \\
\hline $\begin{array}{l}20.5 \text { Egyéb fa-, fonott áru } \\
\text { gyártása }\end{array}$ & $-0,0202$ & 0,28 & $-0,0215$ & 0,26 & $-0,0171$ & 0,27 & $-0,025$ & 0,18 \\
\hline 15.5 Tejfeldolgozás & $-0,0318$ & 0,26 & $-0,033$ & 0,25 & $-0,0289$ & 0,255 & $-0,0382$ & 0,185 \\
\hline $\begin{array}{l}24.5 \text { Tisztítószer, testápolási } \\
\text { cikk gyártása }\end{array}$ & $-0,0129$ & 0,18 & $-0,043$ & 0,22 & $-0,0193$ & 0,06 & $-0,0451$ & 0,2 \\
\hline 24.1 Vegyi alapanyag gyártása & $-0,0269$ & 0,115 & $-0,0225$ & 0,18 & $-0,0226$ & 0,19 & $-0,0256$ & 0,12 \\
\hline $\begin{array}{l}32.2 \text { Ipari híradás-technikai } \\
\text { termék gyártása }\end{array}$ & $-0,0204$ & 0,095 & $-0,0205$ & 0,085 & $-0,0148$ & 0,21 & $-0,0155$ & 0,21 \\
\hline $\begin{array}{l}\text { 29.7 Máshova nem sorolt } \\
\text { háztartási készülék gyártása }\end{array}$ & $-0,0313$ & 0,085 & $-0,0321$ & 0,06 & $-0,0262$ & 0,12 & $-0,03$ & 0,095 \\
\hline 17.1 Textilszálak fonása & $-0,0253$ & 0,07 & 0,0844 & 0,05 & $-0,0296$ & 0,055 & 0,0876 & 0,044 \\
\hline 33.1 Orvosi müszer gyártása & $-0,0274$ & 0,06 & $-0,0132$ & 0,46 & $-0,0382$ & 0,008 & $-0,0125$ & 0,49 \\
\hline $\begin{array}{l}31.1 \text { Villamos motor, } \\
\text { áramfejlesztő gyártása }\end{array}$ & $-0,0475$ & 0,044 & $-0,0091$ & 0,42 & $-0,0434$ & 0,11 & $-0,0043$ & 0,36 \\
\hline $\begin{array}{l}31.6 \text { Egyéb villamos termék } \\
\text { gyártása }\end{array}$ & $-0,0534$ & 0,03 & $-0,0238$ & 0,31 & $-0,0864$ & 0,029 & $-0,0207$ & 0,36 \\
\hline $\begin{array}{l}\text { 15.6 Malomipari termék, } \\
\text { keményítő gyártása }\end{array}$ & $-0,0612$ & 0,025 & $-0,0543$ & 0,049 & $-0,031$ & 0,27 & $-0,0441$ & 0,12 \\
\hline $\begin{array}{l}\text { 26.4 Égetett agyag építőanyag } \\
\text { gyártása }\end{array}$ & $-0,0479$ & 0,014 & $-0,02$ & 0,27 & $-0,0343$ & 0,09 & $-0,0118$ & 0,46 \\
\hline $\begin{array}{l}28.2 \text { Fémtartály, fütési kazán, } \\
\text { radiátor gyártása }\end{array}$ & $-0,0901$ & 0,005 & $-0,0784$ & 0,033 & $-0,0892$ & 0,015 & $-0,0739$ & 0,04 \\
\hline
\end{tabular}

Forrás: saját számítások Excel 2003-ban és Geoda 0.9.5-i szoftverrel.

Megjegyzés: az ágazatok sorba rendezése az iparban és építőiparban foglalkoztatottak számához képest, Budapest adatainak figyelembevételével mért Moran index értékek alapján történt.

Magyarázat $\square$ - erősen pozitívan autokorrelált; $\square$ - gyengén pozitívan autokorrelált; $\square$ - nem autokorrelált;

$\square$ - gyengén negatívan autokorrelált; $\square$ - erősen negatívan autokorrelált 
Van azonban három alágazat, amelyeket az alapértelmezésbeli Moran-index értékeik alapján térben erősen pozitívan autokorreláltnak tekinthetünk, miközben EG $\gamma$ értékeik alapján térben közepesen koncentráltak: 19.3 Lábbeli gyártás, 34.3 Közúti gépjármü, gépjármümotor alkatrészeinek gyártása, 29.3 Mezőgazdasági gép gyártása. Sőt, az összes foglalkoztatottak számához viszonyítva - Budapesttel - már térben erősen koncentráltak is.

Fontosnak tartom kiemelni az élelmiszeripari alágazatokat is. Ezek az alágazatok térben nem, vagy csak gyengén koncentráltak és - a 15.6 Malomipari termék, keményítö gyártása alágazat kivételével, amelyik erősen negatívan autokorrelált - nem autokorreláltak. Ez az eredmény a várakozásoknak megfelelő, hiszen az élelmiszeripar a lakosság egészét kell, hogy ellássa nap, mint nap, így a szállítási költségek minimalizálása érdekében a fogyasztók közelébe kell települnie.

Magyarországon a tradicionális iparágak térbeli koncentrációja, a nemzetközi tanulmányok eredményeivel ellentétben nem kifejezetten magas, sőt többnyire negatív EG $\gamma$ értékekkel rendelkeznek, ilyenek például a textilipari alágazatok, kivéve a 17.6 Kötött, hurkolt kelme gyártása alágazatot, amely térben közepesen koncentrált.

\subsubsection{A hipotézisek tesztelése}

Az EG $\gamma$ mutató és Moran index értékek kiszámítása után megvizsgáltam a mutatószámok gyakorisági eloszlását és a gyakorisági eloszlás változását abban az esetben, ha módosított feltevéssel történt a számítás (12. és 13. ábra), erről a részletesebb elemzést lásd az ábrák után, egybekötve a hipotéziseim tesztelésével.

E grafikonok alapján láthatjuk, hogy az EG $\gamma$ mutató egyik számítási mód esetén sem tekinthető normális eloszlásúnak a 43 alágazat esetében, a Kolmogorov-Szmirnov próba alapján is szignifikánsan különbözik tőle, azonban az is látható, hogy egycsúcsú az eloszlás mind a négy esetben. A Moran index esetében már elfogadható a normalitásra vonatkozó feltételezés, a Kolmogorov-Szmirnov próba alapján a normalitásra vonatkozó hipotézis 5\%-os szinifikancia szinten nem vethető el. Az alágazatok foglalkoztatotti létszáma és a mutatószámok értékei között nincs szignifikáns együttmozgás.

A Moran index esetében megadott p-értékek különböző Moran index értékekhez tartoznak minden egyes alágazat és minden számítási mód esetén, hiszen a p-értékek $43 * 4$ különböző eloszlásból származnak. Ezért a Moran index értékeket módosítottam olyan módon, hogy az eloszlásuk megmaradjon, de a p-értékek sorrendjét vegyék fel. 
12. ábra: Az EG $\gamma$ mutató gyakorisági eloszlásai

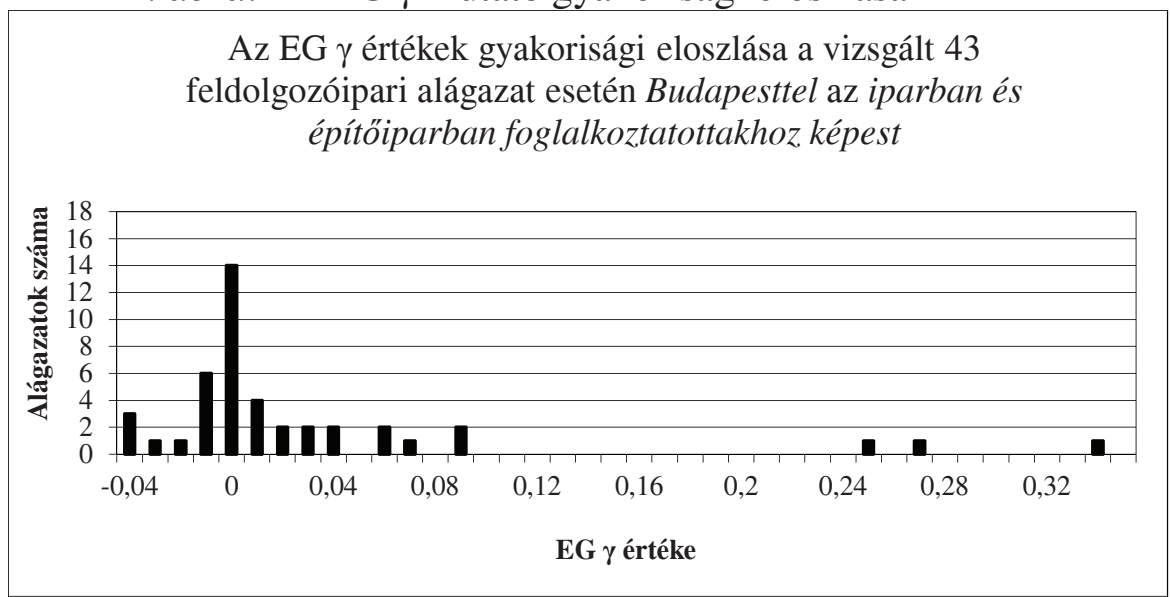

$\mu(\mathrm{EG} \gamma)=0,02892$

$\sigma(\mathrm{EG} \gamma)=0,08374$

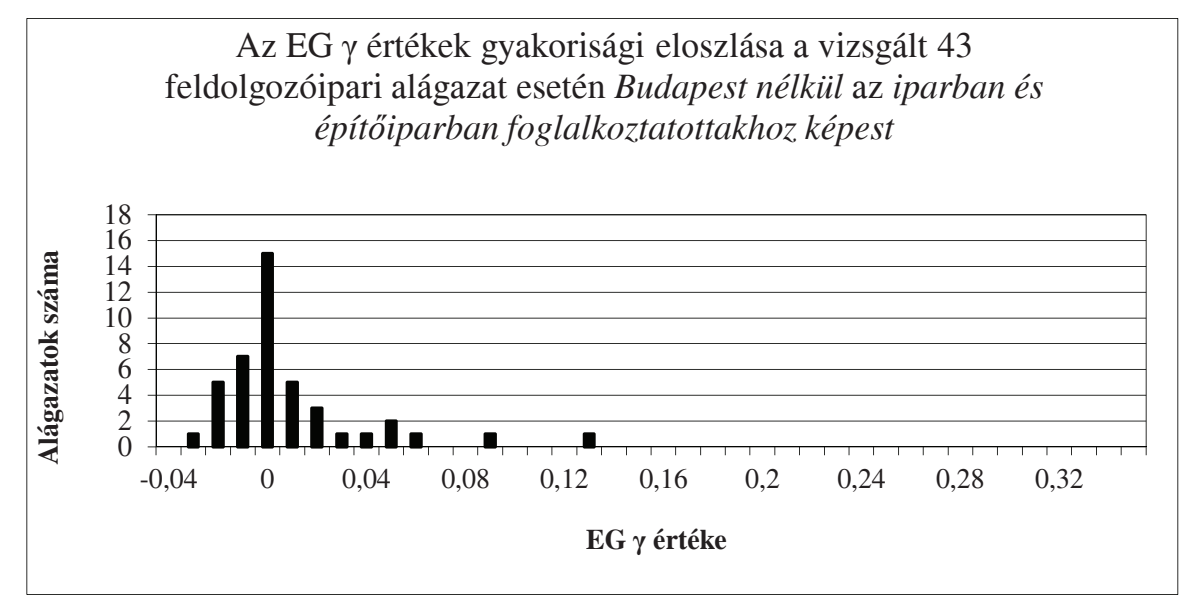

$\mu(\mathrm{EG} \gamma)=0,01511$

$\sigma(\mathrm{EG} \gamma)=0,03028$

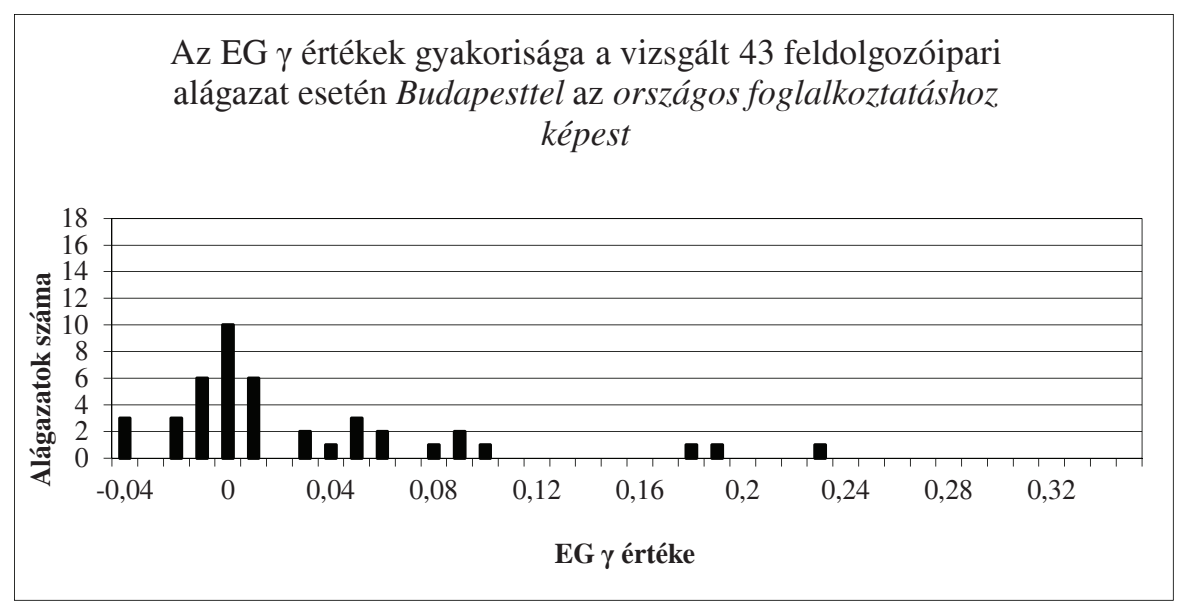

$\mu(\mathrm{EG} \gamma)=0,02247$

$\sigma(\mathrm{EG} \gamma)=0,07775$

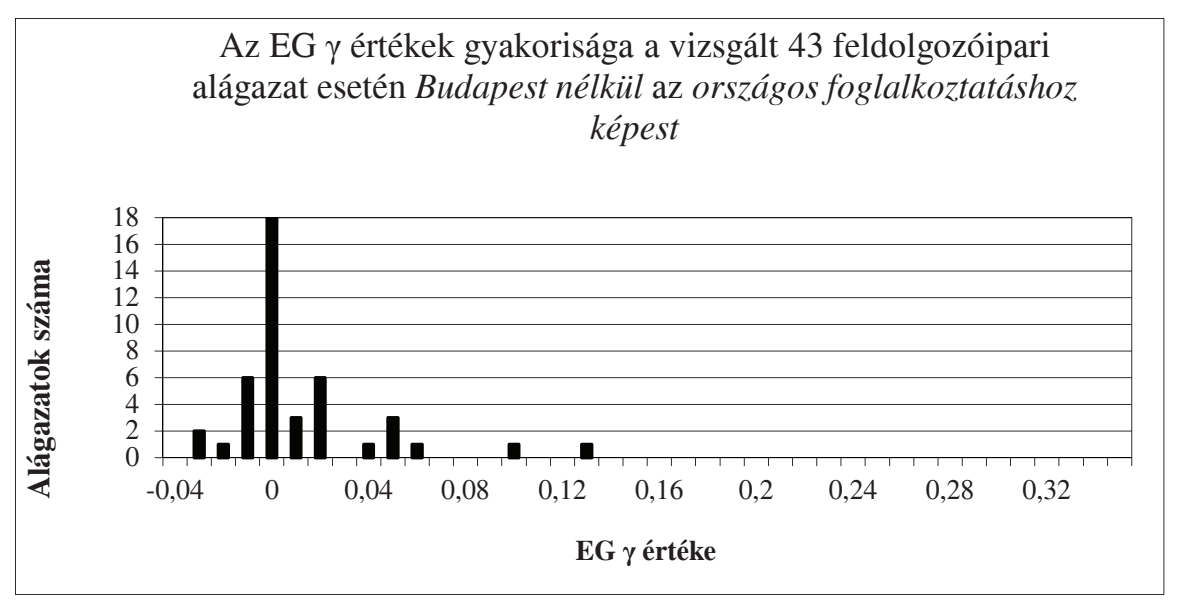

$\mu(\mathrm{EG} \gamma)=0,01546$

$\sigma(\mathrm{EG} \gamma)=0,03042$ 
13. ábra: A Moran index gyakorisági eloszlásai

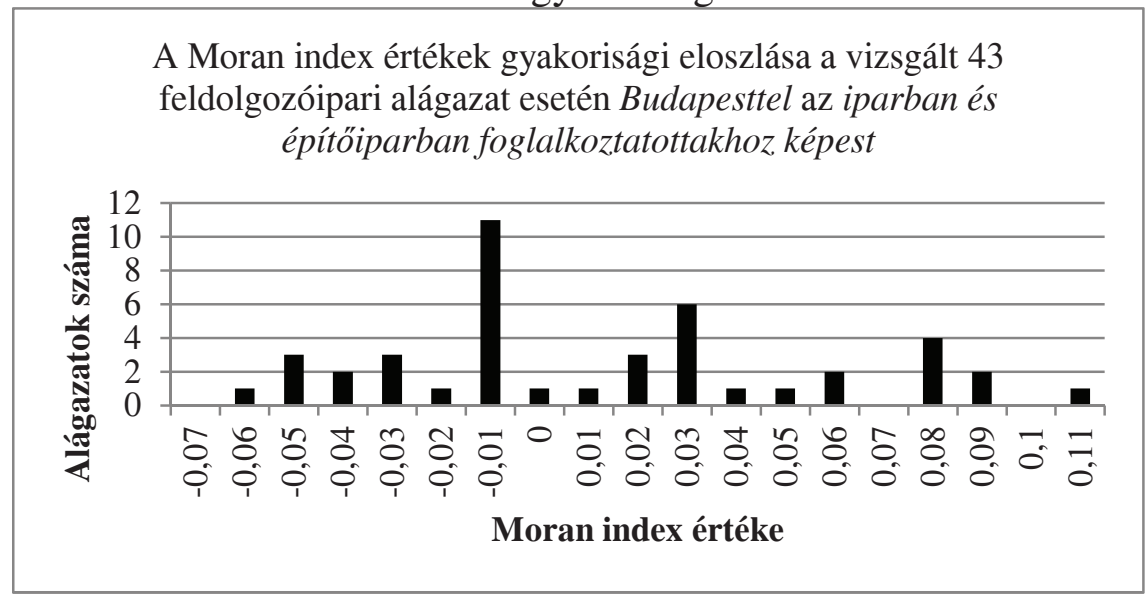

$\mu($ Moran $\mathrm{I})=0,00819$

$\sigma($ Moran I $)=0,04377$

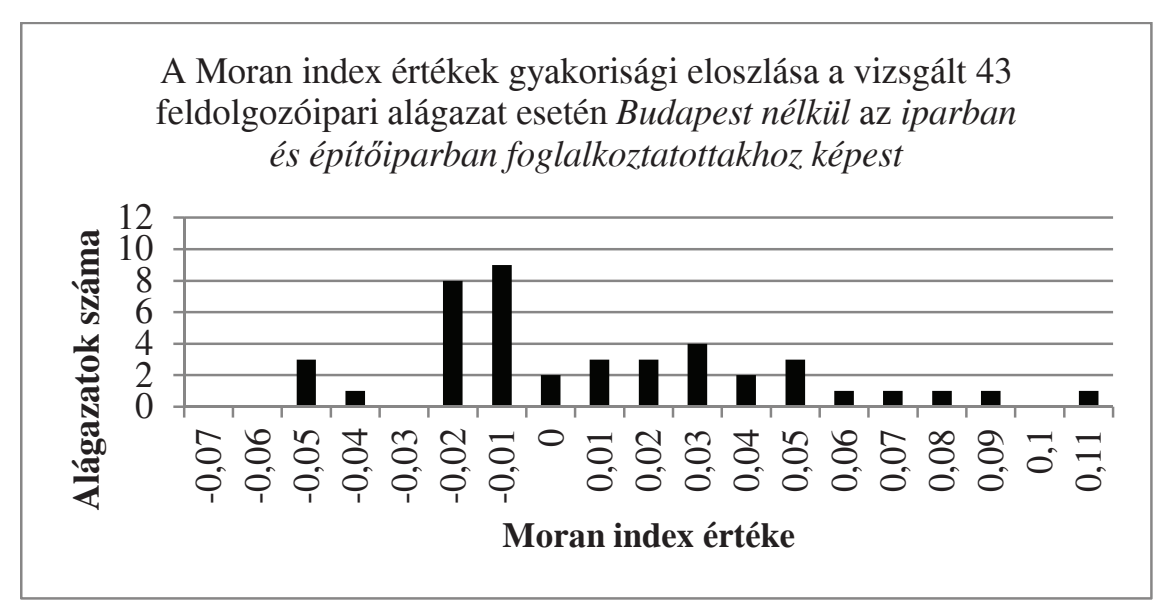

$\mu($ Moran I $)=0,00386$

$\sigma($ Moran I $)=0,03791$

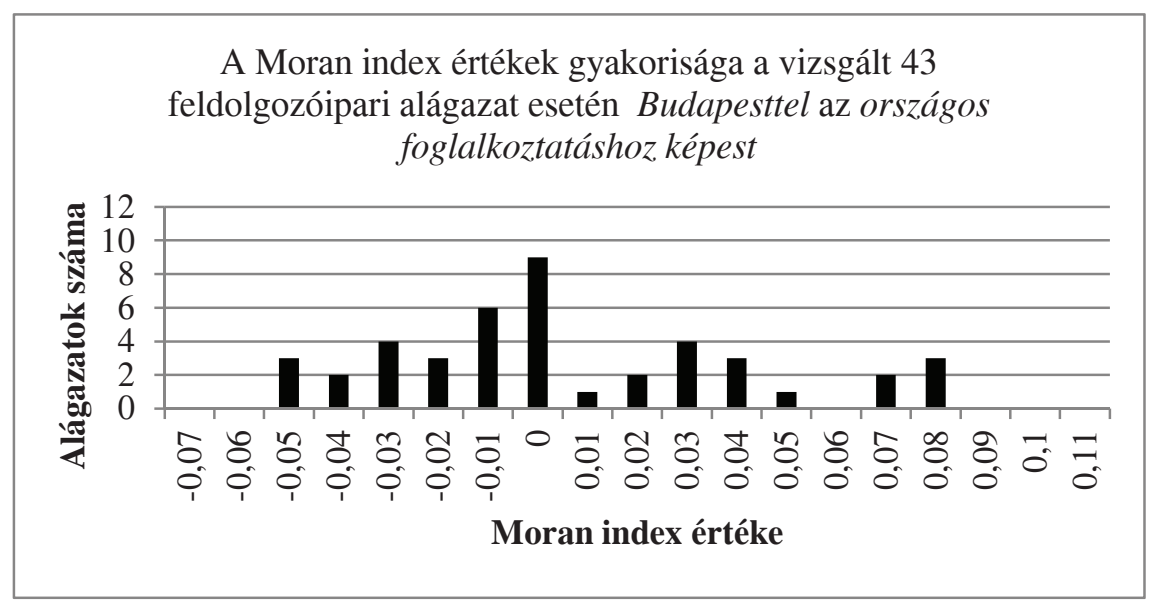

$\mu($ Moran I $)=0,00019$

$\sigma($ Moran I $)=0,03705$

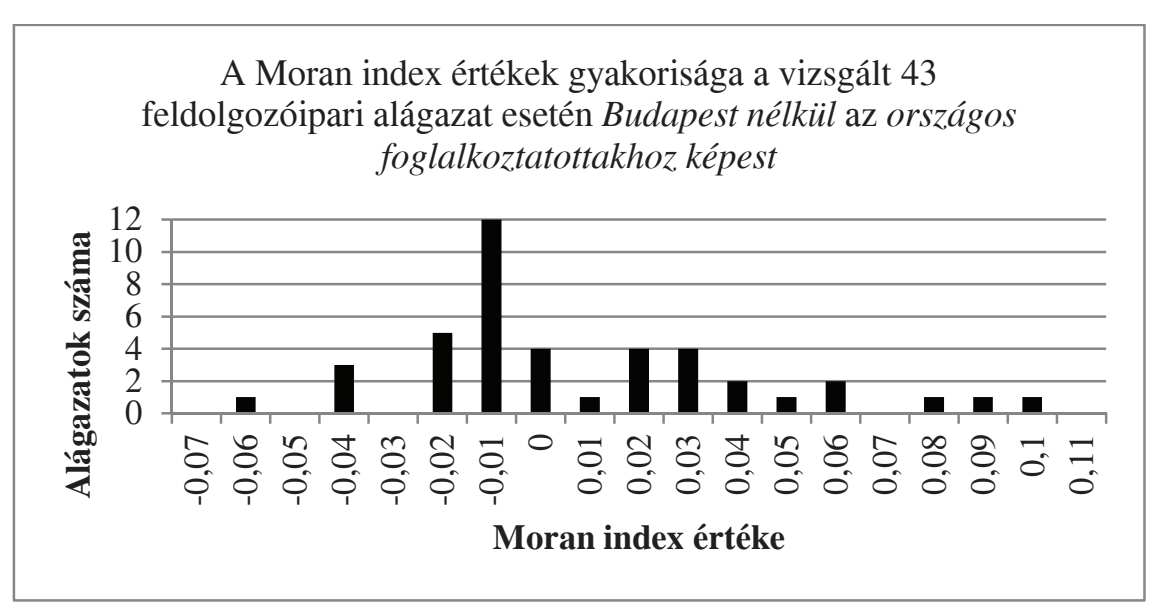

$\mu($ Moran I $)=0,00559$

$\sigma($ Moran I $)=0,03929$ 
Ennek érdekében a p-értékeknek egy-egy inverz logisztikus függvényével becsültem a Moran index értékeket legkisebb négyzetek módszerével.

Az eredeti p-értékeket olyan módon transzformáltam, hogy azt jelentsék: az adott területi $d_{i}=s_{i}-x_{i}$ értékek területi egységek között való összes ${ }^{29}$ permutálása mellett kiszámított lehetséges Moran index értékek mekkora hányadánál nagyobb a valódi kiszámított érték. Tehát várható értéknél nagyobb Moran indexek esetén a $p_{\text {új }}=1-\mathrm{p}$ transzformációt alkalmaztam, várható értéknél kisebb Moran index értékek esetében pedig meghagytam az ereteti p-értékeket: $p_{\text {új }}=p$.

Négy különböző becslőegyenletet használtam a négy különböző mutatószám sorozathoz (Budapesttel iparban és építőiparban foglalkoztatottakhoz mérten, Budapest nélkül iparban és építőiparban foglalkoztatottakhoz mérten, Budapesttel nemzetgazdaság egészében foglalkoztatottakhoz mérten, Budapest nélkül nemzetgazdaság egészében foglalkoztatottakhoz mérten), és mind a négy egyenlet monoton növekvő függvénye lett a púj értékeknek. A becslőegyenleteket és a kiszámított regressziós paraméter értékeket az I. melléklet 1-4. táblái tartalmazzák.

\section{Az I. és II. hipotézisek tesztelése}

Kiszámítottam az egyes értéksorok közötti lineáris autokorrelációs együtthatók értékét, valamint t-próbát végeztem annak eldöntésére, hogy az $x_{i}$ értékek kiszámításának módja befolyásolja-e az EG $\gamma$, illetve a Moran index értékek átlagát (7-10. táblázat). Ennek eredménye alapján a következőket állapíthatjuk meg:

a. Budapest adatainak figyelembevételelelhagyása (EG $\gamma$ mutató - térbeli koncentráció): A térbeli koncentráció mutatószáma esetében a nagy értékek csökkenése és a kis negatív értékek növekedése tapasztalható, így az EG $\gamma$ értékek szórása csökken, ha kihagyjuk Budapestet. Egyúttal eltünik a három kirívóan magas érték, ez pedig az átlagot csökkenti (13. ábra: az egymás alatt lévő grafikonok összehasonlítása). Sok alágazat esetében azonban a mutató kis mértékben növekszik (43-ból 24, illetve 21 esetben). Ez azt sugallja, hogy azokban az esetekben, amikor az EG $\gamma$ értéke magas, a térbeli koncentrálódás oka Budapest. Ilyenek a Gyógyszergyártás, a Tisztítószer, testápolási cikk gyártása, valamint a Kiadói tevékenység alágazatok. A Budapest adatainak felhasználásával és az azok nélkül mért EG $\gamma$ értékek között pozitív lineáris korrelációt

\footnotetext{
${ }^{29}$ Természetesen ez nem az összes lehetséges permutáció, a Geoda 0.9.5-i csak 10000 ilyet generál, azokhoz méri a valódi Moran index értéket.
} 
mérhetünk, amely azonban nem szignifikáns, ez azt jelenti, hogy a két adatsorban nics jelentős együttmozgás. Ennek ellenére a t-próba alapján az átlagok közötti eltérés nem szignifikáns, ez feltehetően az ellentétes irányú változásoknak köszönhető (7. táblázat). A korrelációs értékek alapján az I. hipotézis EG $\gamma$ mutatóra vonatkozó része elfogadható, mindkét esetben szignifikáns eltérés tapasztalható a mutató értékében.

7. táblázat: Korrelációk és átlagok eltérése a Budapest adataival és az azok nélkül számított EG $\gamma$ mutató értékek között

\begin{tabular}{|l|l|c|c|c|c|}
\hline \multicolumn{2}{|c|}{ A két összehasonlított EG $\gamma$ adatsor } & \multicolumn{2}{|c|}{ Korreláció } & \multicolumn{2}{c|}{$\begin{array}{c}\text { Átlagok } \\
\text { összehasonlítása }\end{array}$} \\
\cline { 3 - 6 } & $\mathrm{r}$ & $\begin{array}{c}\text { szignifikancia } \\
\text { szint }\end{array}$ & t-érték & $\begin{array}{c}\text { szignifikancia } \\
\text { szint }\end{array}$ \\
\hline $\begin{array}{l}\text { Budapesttel az iparban } \\
\text { és építöiparban } \\
\text { foglalkoztatottakhoz } \\
\text { képest }\end{array}$ & $\begin{array}{l}\text { Budapest nélkül az } \\
\text { iparban és építőiparban } \\
\text { foglalkoztatottakhoz } \\
\text { képest }\end{array}$ & 0,123 & 0,430 & 1,060 & 0,295 \\
\hline $\begin{array}{l}\text { Budapesttel az egész } \\
\text { nemzetgazdaságban } \\
\text { foglalkoztatottakhoz } \\
\text { képest }\end{array}$ & $\begin{array}{l}\text { Budapest nélkül az egész } \\
\text { nemzetgazdaságban } \\
\text { foglalkoztatottakhoz } \\
\text { képest }\end{array}$ & 0,183 & 0,241 & 0,588 & 0,560 \\
\hline
\end{tabular}

Forrás: saját számítások SPSS-ben

b. Budapest adatainak figyelembevételelelhagyása (Moran index - agglomeráció): A Moran index értékek esetében láthatóan nem tapasztalható nagymértékű változás a gyakorisági eloszlásban, (13. ábra: az egymás alatt lévő grafikonok összehasonlítása). Az átlag és a szórás is csökken Budapest elhagyásával az iparban és építöiparban foglalkoztatottakhoz képest mért Moran index értékek esetében, a változás azonban mind a szórás, mind az átlag esetében ellentétes irányú, ha a nemzetgazdaság egészében foglalkoztatottakhoz mérten számolunk. A Budapest adatainak felhasználásával és az azok nélkül mért Moran index értékek között pozitív lineáris korrelációt mérhetünk, amely erősen szignifikáns, a t-próba alapján az átlagok közötti eltérés pedig nem szignifikáns (8. táblázat). Így megállapítható, hogy néhány alágazattól eltekintve - a Textilszálak fonása, a Gyógyszergyártás alágazatok esetében, amikor nagyobb mértékben nőtt a Moran index értéke, és az Egyéb általános rendeltetésü gép gyártása, az Egyéb speciális rendeltetésü gép gyártása és Világítóeszköz gyártása alágazatok esetében, amikor csökkent a Moran index értéke Budapest elhagyásával - nincs jelentős eltérés a kétféle módon kiszámított értékek között. Az I. hipotézis Moran indexre vonatkozó része elvethető, az agglomerálódásban nincs jelentős különbség a Budapest adataival és azok nélkül számolt értékek alapján. 
8. táblázat: Korrelációk és átlagok eltérése a Budapest adataival és az azok nélkül számított Moran index értékek között

\begin{tabular}{|l|l|c|c|c|c|}
\hline \multirow{2}{*}{ A két összehasonlított Moran index adatsor } & \multicolumn{2}{|c|}{ Korreláció } & \multicolumn{2}{|c|}{$\begin{array}{c}\text { Átlagok } \\
\text { összehasonlítása }\end{array}$} \\
\cline { 3 - 6 } & $\mathrm{r}$ & $\begin{array}{c}\text { szignifikancia } \\
\text { szint }\end{array}$ & t-érték & $\begin{array}{c}\text { szignifikancia } \\
\text { szint }\end{array}$ \\
\hline $\begin{array}{l}\text { Budapesttel az iparban } \\
\text { és építőiparban } \\
\text { foglalkoztatottakhoz } \\
\text { képest }\end{array}$ & $\begin{array}{l}\text { Budapest nélkül az } \\
\text { iparban és építöiparban } \\
\text { foglalkoztatottakhoz } \\
\text { képest }\end{array}$ & 0,711 & 0,000 & 0,911 & 0,367 \\
\hline $\begin{array}{l}\text { Budapesttel az egész } \\
\text { nemzetgazdaságban } \\
\text { foglalkoztatottakhoz } \\
\text { képest }\end{array}$ & $\begin{array}{l}\text { Budapest nélkül az egész } \\
\text { nemzetgazdaságban } \\
\text { foglalkoztatottakhoz } \\
\text { képest }\end{array}$ & 0,603 & 0,000 & $-1,038$ & 0,305 \\
\hline
\end{tabular}

Forrás: saját számítások SPSS-ben

\section{c. Iparban és építöiparban foglalkoztatottakhoz/nemzetgazdaságban foglalkoztatottakhoz} mérten (EG y mutató - térbeli koncentráció): a viszonyítási alap megváltoztatásával az EG $\gamma$ értékeiben nincsen az előzőhöz hasonlóan nagymértékű változás, így az átlag és a szórás sem változik jelentősen (12. ábra: az egymás mellett lévő grafikonok összehasonlítása). A legnagyobb EG $\gamma$ értékek esetében ekkor is csökkenést tapasztalhatunk a Budapest adataival számolt mutatóértékekben, ez pedig azt jelenti, hogy - amint az 5. és 7. ábra (térképek) elemzése során megállapítottuk - a három térben leginkább koncentrált alágazat inkább az iparra és építőiparra specializálódott területeken kívül található meg, például Budapesten és/vagy környékén. Ez ismét csak Budapestnek köszönhető, hiszen kétféle számítás alapját nyújtó $x_{i}$ értékek között nagyon nagy különbség van, az iparban és építőiparban foglalkoztatottak esetében $x_{i}=0,13$, míg a nemzetgazdaság egészére vonatkozó érték $x_{i}=0,2$.

9. táblázat: Korrelációk és átlagok eltérése az ipar-építőiparhoz, illetve a nemzetgazdaságban foglalkoztatottakhoz viszonyítva számított EG $\gamma$ értékek között

\begin{tabular}{|l|l|c|c|c|c|}
\hline \multicolumn{2}{|c|}{ A két összehasonlított EG $\gamma$ adatsor } & \multicolumn{2}{|c|}{ Korreláció } & \multicolumn{2}{c|}{$\begin{array}{c}\text { Átlagok } \\
\text { Összehasonlítása }\end{array}$} \\
\cline { 2 - 5 } & $\mathrm{r}$ & $\begin{array}{c}\text { szignifikancia } \\
\text { szint }\end{array}$ & t-érték & $\begin{array}{c}\text { szignifikancia } \\
\text { szint }\end{array}$ \\
\hline $\begin{array}{l}\text { Budapesttel az iparban és } \\
\text { építöiparban } \\
\text { foglalkoztatottakhoz } \\
\text { képest }\end{array}$ & $\begin{array}{l}\text { Budapesttel az egész } \\
\text { nemzetgazdaságban } \\
\text { foglalkoztatottakhoz } \\
\text { képest }\end{array}$ & 0,917 & 0,000 & 1,266 & 0,213 \\
\hline $\begin{array}{l}\text { Budapest nélkül az } \\
\text { iparban és építőiparban } \\
\text { foglalkoztatottakhoz } \\
\text { képest }\end{array}$ & $\begin{array}{l}\text { Budapest nélkül az egész } \\
\text { nemzetgazdaságban } \\
\text { foglalkoztatottakhoz } \\
\text { képest }\end{array}$ & 0,990 & 0,000 & $-0,550$ & 0,585 \\
\hline
\end{tabular}

Forrás: saját számítások SPSS-ben 
Sok alágazat esetében a mutató kismértékben növekszik (43-ból 25 esetben). Egyetlen alágazatot tekintve - 34.1 Közúti gépjármü gyártása - van nagyobb mértékü növekedés az EG $\gamma$ mutató értékében - ez egy térben erősebben koncentrálódott alágazat, mely ezt nem Budapestnek köszönheti. A mutató bázisértékeinek változtatása esetén a korreláció pozitív és erősen szignifikáns, tehát erős együttmozgás van az adatértékekben. A tpróba alapján az átlagok közötti eltérés nem szignifikáns (9. táblázat). A II. hipotézis EG $\gamma$ mutatóra vonatkozó része elvethető, nincs szignifikáns eltérés a különböző viszonyítási alapokkal mért adatértékek között.

d. Iparban és építöiparban foglalkoztatottakhoz/nemzetgazdaságban foglalkoztatottakhoz mérten (Moran index - agglomeráció): A Moran index értékek esetében nem tapasztalható nagymértékü változás a gyakorisági eloszlásban, ha a viszonyítási alapon változtatunk (iparban és építőiparban vagy nemzetgazdaság egészében) (13. ábra: az egymás mellett lévő garafikonok összehasonlítása). Az átlag és a szórás növekszik, ha Budapest adatait beszámítjuk, ellentétes irányú a változás azonban, ha a Budapest adatai nélkül vett Moran index értékeket hasonlítjuk össze. A mutató bázisértékeinek megvátozatatása esetén a korreláció pozitív és erősen szignifikáns, tehát erős együttmozgás van az adatértékekben. A t-próba alapján az átlagok közötti eltérés szignifikáns (10. táblázat), de csak a Budapest adatainak beszámításával nyert két mutató átlagai között: itt 2,7\%-os szignifikancia szinten eltérés mutatkozik. A Budapest adatai nélkül nyert két mutató között nincs szignifikáns eltérés. A II. hipotézis Moran indexre vonatkozó része elvethető, nincs szignifikáns eltérés a különböző bázisokkal mért mutatószám-értékek között, illetve az eltérés Budapestnek köszönhető.

10. táblázat: Korrelációk és átlagok eltérése az ipar-építőiparhoz, illetve nemzetgazdaságban foglalkoztatottakhoz viszonyítva számított Moran index értékek között

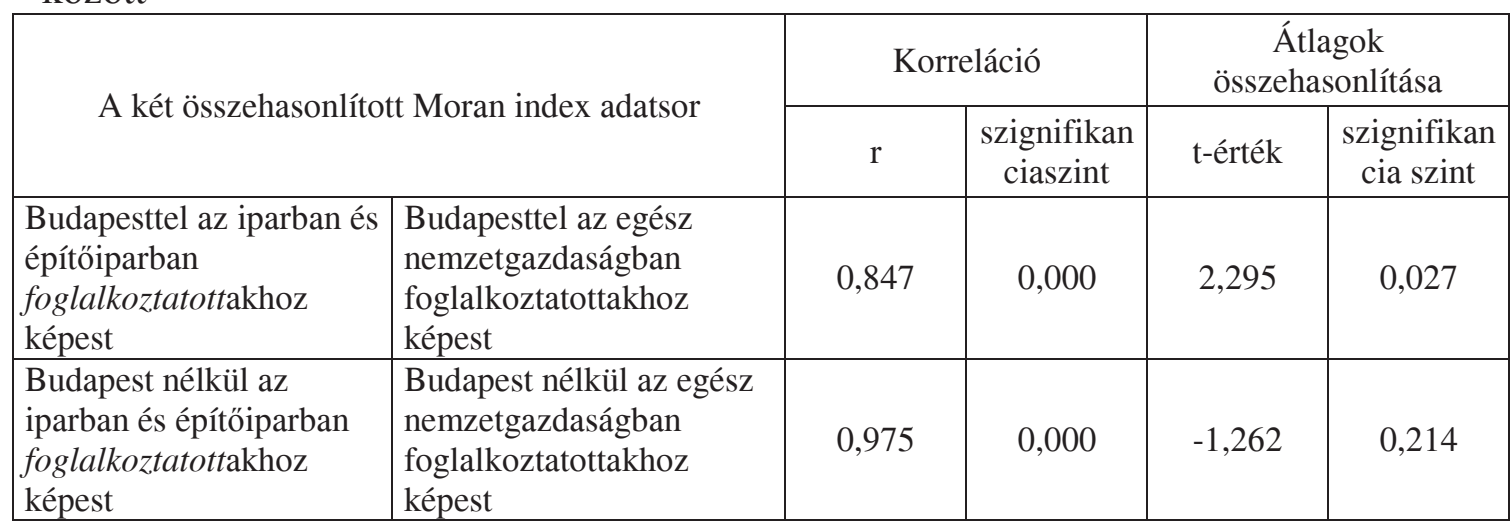

Forrás: saját számítások SPSS-ben 


\section{A III. hipotézis tesztelése}

Elemeztem, hogy a tudásintenzív feldolgozóipari alágazatok különböznek-e a nem tudásintenzívnek nevezettektől a mutatószámokat illetően. A tudásintenzív ágazatok definíciója a következő alfejezetben található meg bővebben, azonban a TEÁOR'03 alapján az az OECD 2001-es osztályozása szerint tudásintenzívnek nevezett ágazatokhoz tartozó alágazatokat tekintettem tudás-intenzívnek (11. táblázat). A tudásintenzív alágazatok száma 31, ezek közül 19 került a mintába.

11. táblázat: Tudásintenzív feldolgozóipari ágazatok az OECD (2001) osztályozása szerint

\begin{tabular}{|l|c|}
\hline Ágazat & $\begin{array}{c}\text { Figyelembe vett } \\
\text { alágazatok száma }\end{array}$ \\
\hline 24 Vegyi anyag, termék gyártása & 3 \\
\hline 29 Gép, berendezés gyártása & 6 \\
\hline 30 Iroda-, számítógépgyártás & 1 \\
\hline 31 Máshova nem sorolt villamos gép gyártása & 3 \\
\hline 32 Híradás-technikai termék, készülék gyártása & 3 \\
\hline 33 Müszergyártás & 1 \\
\hline 34 Közúti jármú gyártása & 2 \\
\hline
\end{tabular}

Forrás: OECD (2001)

A tudásintenzív és nem tudásintenzív feldolgozóipari alágazatok mutatószámainak összehasonlítása érdekében két független mintás t-próbát végeztem. Ott, ahol a varianciák a Levene teszt alapján szignifikánsan különböztek, a Welch-féle d-próba eredményeit vettem figyelembe (12. és 13. táblázat). Megállapítható, hogy valóban szignifikáns különbség van az EG $\gamma$ mutató értékek átlagában a tudásintenzitástól függően, ott is leginkább akkor, ha Budapest adatait figyelembe vesszük (9\%-os szignifikancia szinten). A Moran index értékek viszont nem különböznek szignifikánsan a tudásintenzitást tekintve.

12. táblázat: Két független mintás t-próba eredmények a tudásintenzív és nem tudásintenzív feldolgozóipari alágazatok EG $\gamma$ átlagainak összehasonlítására

\begin{tabular}{|c|c|c|c|c|c|c|c|c|}
\hline & \multicolumn{3}{|c|}{ Varianciák egyezése } & \multicolumn{5}{c|}{ t-teszt az átlagok egyezőségére } \\
\cline { 2 - 9 } & $\mathrm{F}$ & $\begin{array}{c}\text { szignifikancia } \\
\text { szint }\end{array}$ & feltételezés & $\mathrm{t}$ & sz.fok & $\begin{array}{c}\text { szignifikancia } \\
\text { szint }\end{array}$ & $\begin{array}{c}\text { átlagok } \\
\text { közötti } \\
\text { különbség }\end{array}$ & $\begin{array}{c}\text { a különbség } \\
\text { standard } \\
\text { hibája }\end{array}$ \\
\hline $\begin{array}{c}\text { Budapesttel } \\
\text { iparhoz }\end{array}$ & 2,923 & 0,095 & $\begin{array}{c}\text { varianciák } \\
\text { azonosak }\end{array}$ & 1,736 & 41 & 0,090 & 0,04360 & 0,025121 \\
\hline $\begin{array}{c}\text { Budapest } \\
\text { nélkül } \\
\text { iparhoz }\end{array}$ & 7,350 & 0,010 & $\begin{array}{c}\text { varianciák } \\
\text { különböznek }\end{array}$ & 1,392 & 23,845 & 0,177 & 0,01380 & 0,00991 \\
\hline $\begin{array}{c}\text { Budapesttel } \\
\text { összeshez }\end{array}$ & 1,350 & 0,252 & $\begin{array}{c}\text { varianciák } \\
\text { azonosak }\end{array}$ & 1,735 & 41 & 0,090 & 0,04047 & 0,02332 \\
\hline $\begin{array}{c}\text { Budapest } \\
\text { nélkül } \\
\text { összeshez }\end{array}$ & 7,483 & 0,009 & $\begin{array}{c}\text { varianciák } \\
\text { különböznek }\end{array}$ & 1,581 & 23,930 & 0,127 & 0,01562 & 0,00988 \\
\hline
\end{tabular}

Forrás: saját szerkesztés 
13. táblázat: Két független mintás t-próba eredmények a tudásintenzív és nem tudásintenzív feldolgozóipari alágazatok Moran index értékei átlagainak összehasonlítására

\begin{tabular}{|c|c|c|c|c|c|c|c|c|}
\hline & \multicolumn{2}{|c|}{ Varianciák egyezése (Levene teszt) } & \multicolumn{5}{|c|}{ t-teszt az átlagok egyezőségére } \\
\cline { 2 - 9 } & $\mathrm{F}$ & $\begin{array}{c}\text { szignifikancia } \\
\text {-szint }\end{array}$ & feltételezés & $\mathrm{t}$ & sz.fok & $\begin{array}{c}\text { szignifikancia } \\
\text { szint }\end{array}$ & $\begin{array}{c}\text { átlagok } \\
\text { közötti } \\
\text { különbség }\end{array}$ & $\begin{array}{c}\text { a különbség } \\
\text { standard } \\
\text { hibája }\end{array}$ \\
\hline $\begin{array}{c}\text { Budapesttel } \\
\text { iparhoz }\end{array}$ & 0,059 & 0,809 & $\begin{array}{c}\text { varianciák } \\
\text { azonosak }\end{array}$ & 1,063 & 41 & 0,294 & 0,01401 & 0,01318 \\
\hline $\begin{array}{c}\text { Budapest } \\
\text { nélkül } \\
\text { iparhoz }\end{array}$ & 0,973 & 0,330 & $\begin{array}{c}\text { varianciák } \\
\text { azonosak }\end{array}$ & 0,604 & 41 & 0,549 & 0,00708 & 0,01172 \\
\hline $\begin{array}{c}\text { Budapesttel } \\
\text { összeshez }\end{array}$ & 1,056 & 0,310 & $\begin{array}{c}\text { varianciák } \\
\text { azonosak }\end{array}$ & 0,714 & 41 & 0,479 & 0,00803 & 0,01125 \\
\hline $\begin{array}{c}\text { Budapest } \\
\text { nélkül } \\
\text { összeshez }\end{array}$ & 0,473 & 0,496 & $\begin{array}{c}\text { varianciák } \\
\text { azonosak }\end{array}$ & 0,487 & 41 & 0,629 & 0,00600 & 0,01233 \\
\hline
\end{tabular}

Forrás: saját szerkesztés

14. táblázat: Az EG $\gamma$ mutató és Moran index feldolgozóipari alágazatokon felvett értékenek átlagai a tudásintenzitás függvényében

\begin{tabular}{|c|c|c|c|}
\hline \multicolumn{2}{|c|}{} & tudásintenzív & $\begin{array}{c}\text { nem } \\
\text { tudásintenzív }\end{array}$ \\
\hline \multirow{4}{*}{ EG $\gamma$} & Budapesttel iparhoz & 0,0533 & 0,0097 \\
\cline { 2 - 4 } & Budapest nélkül iparhoz & 0,0228 & 0,0090 \\
\cline { 2 - 4 } & Budapesttel összeshez & 0,0451 & 0,0046 \\
\cline { 2 - 4 } & Budapest nélkül összeshez & 0,0242 & 0,0086 \\
\hline \multirow{4}{*}{ Moran index } & Budapesttel iparhoz & 0,0004 & 0,0144 \\
\cline { 2 - 4 } & Budapest nélkül iparhoz & $-0,0001$ & 0,0070 \\
\cline { 2 - 4 } & Budapesttel összeshez & $-0,0043$ & 0,0037 \\
\cline { 2 - 4 } & Budapest nélkül összeshez & 0,0022 & 0,0082 \\
\hline
\end{tabular}

Forrás: saját szerkesztés

A fentiek alapján megállapíthatjuk, hogy a tudásintenzív feldolgozóipari alágazatokban nagyobb térbeli koncentráció tapasztalható, mint a nem tudásintenzív alágazatok esetében, de csak a budapesti vállalkozások figyelembevétele esetén. Így a 3. hipotézis EG $\gamma$ mutatóra vonatkozó része 9\%-os szignifikancia szint mellett elfogadható. A Moran indexre vonatkozó részt viszont el kell vetnünk, sőt megállapítható, hogy ha nem is szignifikáns, de az eltérés az agglomerációban ellentétes irányú, a tudásintenzív alágazatok kevésbé agglomerálódnak, mint a nem tudásintenzívek. Valójában ez egybevág azzal a nemzetközi szakirodalomban megfogalmazott megfigyeléssel, hogy a tudás túlcsordulás hatása jelentős, de térben viszonylag „gyorsan” lecseng, esetünkben a kistérségi határokon általában kevés esetben nyúlik túl. 


\section{A IV. hipotézis tesztelése}

A táblázatokból leolvasható eredmények szerint a feldolgozóipari alágazatok igen vegyes képet mutatnak a térbeli koncentrálódás és agglomerálódás tekintetében. A 15. és 16. táblázatokban azt láthatjuk, hogy e két dimenzió mentén (agglomerálódás és térbeli koncentrálódás) húsz osztályba sorolhatók az (al)ágazatok. Ebben az esetben már csak az iparban és építőiparban foglalkoztatottakhoz viszonyított adatértékek alapján ábrázoltam az alágazatokat, mivel a II. hipotézis, mely szerint a viszonyítási alap változtatása szignifikáns eltérést okoz, elvetésre került. E húsz közül a négy szélsőséges osztály értelmezése a következő lehet:

1. A táblázat bal alsó osztályába a térben szétszórt és térben erősen negatívan autokorrelált ágazatok tartoznak, ami azt jelenti, hogy ezekben az ágazatokban a vállalkozások igyekeznek egymástól távol elhelyezkedni, a centripetális erők megléte kérdéses, azokat messze felülírják a centrifugális erők. Ilyenek Budapest adataival a 17.1 Textilszálak fonása és a 32.2 Ipari híradás-technikai termék gyártása alágazatok, ez utóbbi Budapest adatai nélkül is.

2. A táblázat bal felső osztályába a térben erösen koncentrált és térben erösen negatívan autokorrelált ágazatok tartoznak, amelyekben a centripetális erők megléte erőteljesen kimutatható, azonban ezen hatóerők sugara nem mutat túl a kistérségi határokon. Ilyenek Budapest adataival a 29.7 Máshova nem sorolt háztartási készülék gyártása és a 33.1 Orvosi müszer gyártása alágazatok.

15. táblázat: Térbeli koncentráció és agglomeráció a vizsgált feldolgozóipari alágazatokban Budapest adataival az iparban és építőiparban foglalkoztatottak térbeli eloszlásához viszonyítva

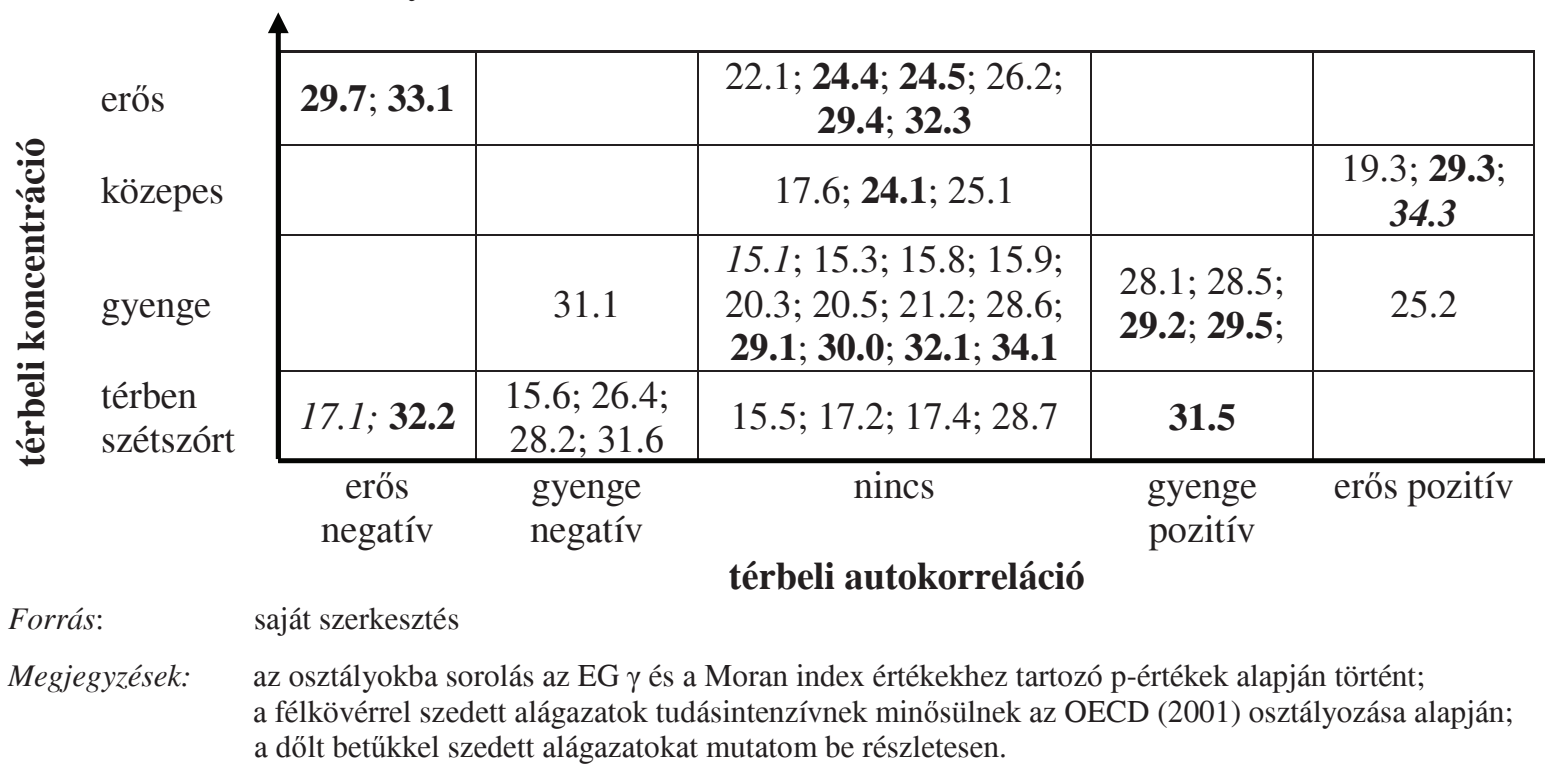


3. A táblázat jobb alsó osztályába a térben szétszórt és térben erősen autokorrelált ágazatok kerülnek, amelyekben a vállalkozások igyekeznek egymástól távol települni, azonban csak kevés vállalatról lévén szó (magas az ágazati koncentráció), sok kistérségben nincs jelen az ágazat, ezen kistérségek pedig térben összefüggő területeket alkotnak. Ilyen szélsőséges alágazat a gyakorlatban Magyarországon nem figyelhető meg.

4. A táblázat jobb felső osztályába a térben erősen koncentrált és térben erősen autokorrelált ágazatok kerültek. Ezekben a vállalatokat egymás közelébe vonzó centripetális erők megléte erőteljesen kimutatható, és ezen erők sugara túllépi a kistérségi határokat. Ennyire szélsőséges alágazatot sem találhatunk a 43 feldolgozóipari alágazat között.

16. táblázat: Térbeli koncentráció és agglomeráció a vizsgált feldolgozóipari ágazatokban Budapest adatai nélkül, az iparban és építöiparban foglalkoztatottak térbeli eloszlásához viszonyítva

\begin{tabular}{|c|c|c|c|c|c|}
\hline erős & & & $\begin{array}{c}25.1 ; 26.2 ; \mathbf{2 9 . 4} ; 32.3 ; \\
33.1\end{array}$ & & \\
\hline közepes & 29.7 & & $20.5 ; \mathbf{2 4 . 1} ; 29.1$ & 19.3 & \\
\hline gyenge & & 28.2 & $\begin{array}{c}15.1 ; 15.3 ; 15.8 ; 15.9 ; \\
20.3 ; 22.1 ; 26.4 ; 28.1 \\
28.5 ; 28.6 ; \mathbf{2 9 . 2} ; \mathbf{2 9 . 3} \\
\mathbf{2 9 . 5} ; \mathbf{3 1 . 1} ; \mathbf{3 1 . 5} ; \mathbf{3 2 . 1} ; \\
\mathbf{3 4 . 1}\end{array}$ & 17.1 & $25.2 ; 34.3$ \\
\hline \multirow[t]{2}{*}{$\begin{array}{l}\text { térben } \\
\text { szétszórt }\end{array}$} & 32.2 & 15.6 & $\begin{array}{c}15.5 ; 17.2 ; 17.4 ; 17.6 ; \\
21.2 ; \mathbf{2 4 . 5} ; 28.7 ; \mathbf{3 0 . 0} ; \\
\mathbf{3 1 . 6}\end{array}$ & 24.4 & \\
\hline & $\begin{array}{l}\text { erős } \\
\text { negatív }\end{array}$ & $\begin{array}{l}\text { gyenge } \\
\text { negatív }\end{array}$ & nincs & $\begin{array}{l}\text { gyenge } \\
\text { pozitív }\end{array}$ & $\begin{array}{l}\text { erös } \\
\text { pozitív }\end{array}$ \\
\hline
\end{tabular}

\footnotetext{
Forrás: $\quad$ saját szerkesztés

Megjegyzések: $\quad$ az osztályokba sorolás az EG $\gamma$ és a Moran index értékekhez tartozó p-értékek alapján történt; a félkövérrel szedett alágazatok tudásintenzívnek minősülnek az OECD (2001) osztályozása alapján; a dőlt betűkkel szedett alágazatokat mutatom be részletesen.
}

térbeli autokorreláció

Annak érdekében, hogy e két dimenzió függetlenségét ellenőrizzem és IV. hipotézisemet teszteljem, lineáris korrelációs vizsgálatot végeztem az EG $\gamma$ mutató értékek és a Moran index értékek között. A lineáris korrelációs vizsgálatban ugyancsak a becsült Moran index értékeket használtam. Eredményeim szerint a két mérőszám között semmiféle kapcsolat nem érzékelhető, ami azt jelenti, hogy az EG $\gamma$ mutató értékéből nem lehet következtetni a Moran index értékére, és viszont (17. táblázat). Ennek megfelelően a IV. hipotézist elfogadhatjuk, a magyar feldolgozóipari alágazatok esetében az EG $\gamma$ mutató és a Moran index kistérségi szinten függetlenek egymástól. 
17. táblázat: Korreláció az EG $\gamma$ mutató és a Moran index értékek között

\begin{tabular}{|l|c|c|}
\hline \multicolumn{1}{|c|}{ Az érték kiszámításának alapja } & \multicolumn{2}{c|}{ A Pearson-féle lineáris korreláció együttható } \\
\cline { 2 - 3 } & r értéke & szignifikancia szintje \\
\hline $\begin{array}{l}\text { Budapesttel az iparban és építőiparban foglalkoztatottakhoz } \\
\text { képest }\end{array}$ & 0,007 & 0,966 \\
\hline $\begin{array}{l}\text { Budapest nélkül az iparban és építőiparban } \\
\text { foglalkoztatottakhoz képest }\end{array}$ & 0,030 & 0,849 \\
\hline $\begin{array}{l}\text { Budapesttel az egész nemzetgazdaságban } \\
\text { foglalkoztatottakhoz képest }\end{array}$ & $-0,014$ & 0,927 \\
\hline $\begin{array}{l}\text { Budapest nélkül az egész nemzetgazdaságban } \\
\text { foglalkoztatottakhoz képest }\end{array}$ & 0,003 & 0,987 \\
\hline
\end{tabular}

Forrás: saját szerkesztés

A 15.1 Húsfeldolgozás és a 34.3 Közúti gépjármü, gépjármümotor alkatrészeinek gyártása alágazatokat külön is megvizsgáltam.

\subsubsection{A Húsfeldolgozás alágazat}

Ebbe az alágazatba tartozik minden, a hús feldolgozásával és tartósításával, nyersbőr és gyapjú, toll és pehely nyerésével és húskészítmény gyártásával kapcsolatos tevékenység. Ez az alágazat a többi élelmiszeripari alágazathoz hasonlóan térben nem koncentrált, térbeli autokorreláció sem mutatható ki esetében és a Herfindahl index sem mutat ágazati koncentrációt. Az alágazatban a vizsgálat időpontjában 599 vállalkozás müködött, amelyeknek alkalmazásában közel 27500 fö állt (18. táblázat).

18. táblázat: A Húsfeldolgozás alágazat mutatószám-értékei

\begin{tabular}{|c|c|c|c|c|}
\hline Húsfeldolgozás & $\begin{array}{c}\text { Iparban, építöiparban } \\
\text { foglalkoztatottakhoz } \\
\text { Budapesttel }\end{array}$ & $\begin{array}{c}\text { Összes } \\
\text { foglalkoztatotthoz } \\
\text { Budapesttel }\end{array}$ & $\begin{array}{c}\text { Iparban, építőiparban } \\
\text { foglalkoztatottakhoz } \\
\text { Budapest nélkül }\end{array}$ & $\begin{array}{c}\text { Összes } \\
\text { foglalkoztatotthoz } \\
\text { Budapest nélkül }\end{array}$ \\
\hline Moran index & 0,0187 & 0,0375 & 0,0076 & 0,0039 \\
\hline EG $\gamma$ mutató & 0,0044 & 0,0152 & 0,0048 & 0,0039 \\
\hline $\begin{array}{c}\text { Normalizált } \\
\text { Herfindahl index }\end{array}$ & \multicolumn{2}{|c|}{0,0290} & & 0,0343 \\
\hline
\end{tabular}

Forrás: saját szerkesztés

A 14. és 15. ábrákon látható a Húsfeldolgozás alágazat térbeli eloszlása. Viszonyítási alapnak az iparban foglalkoztatottak kistérségi értékeit vettem. Budapest adatai is szerepelnek a számításokban, ebben az alágazatban ugyanis Budapest nem okoz olyan problémát, mint 
például a szolgáltatások esetében, hiszen Budapesten még az ipari foglalkoztatottsághoz képest is alulreprezentált a húsfeldolgozás $(L Q=0,74)^{30}$.

14. ábra: A Húsfeldolgozás alágazat $L Q$ értékeinek térbeli eloszlása

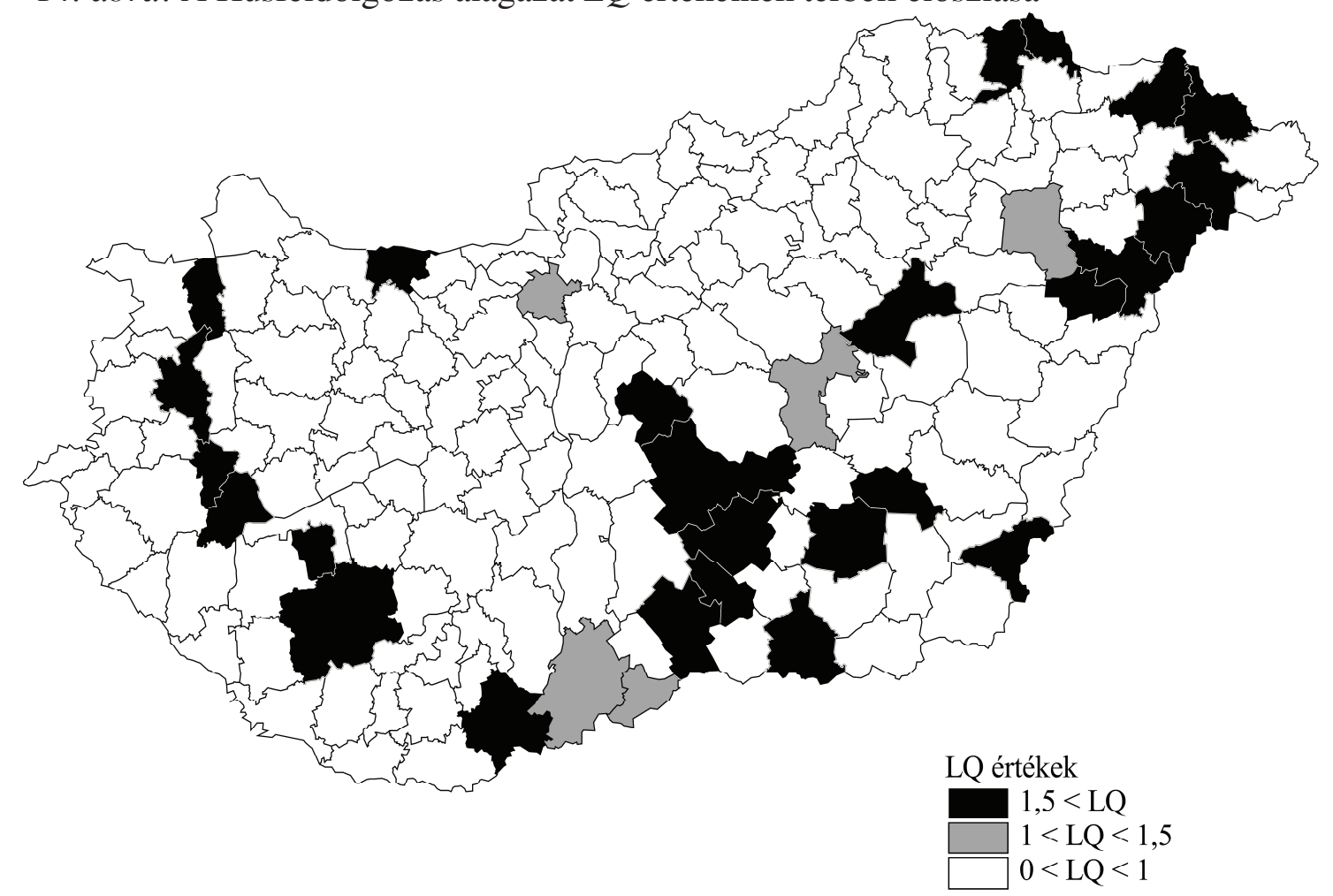

Forrás: saját szerkesztés

A globális mutatók (EG $\gamma$ és Moran I) alapján ugyan sem koncentráció, sem agglomeráció nem mutatható ki, a lokális mutatók, vagyis az $L Q$ és LISA értékek alapján azonban kiemelhető néhány pontszerüen elhelyezkedő kistérség, amelyekben mégis vállalkozások tömörülése tapasztalható. 1,5-nél magasabb $L Q$ értékkel 26 kistérség rendelkezik, ezek között 5 olyan van, amelyben több mint 1000 főt alkalmaznak: a Sárvári, a Szegedi, a Szentesi, a Kecskeméti és a Komáromi kistérségek.

A LISA értékek két kistérség esetében mutatnak agglomerálódást: a Kapuvári és a Zalaszentgróti kistérségek nevezhetők hot spotnak, elsősorban a nagyon sok főt alkalmazó Sárvári kistérséggel való szomszédságuk miatt. Annál több viszont a cold spot: Budapesten és a Pilisvörösvári kistérség kivételével az összes Budapest környéki kistérségben alulreprezentált ez a tevékenység.

${ }^{30}$ az összes foglalkoztatottaknak kb. 20\%-a, míg az iparban foglalkoztatottaknak csak kb.13\%-a dolgozik Budapesten. 
15. ábra: Kistérségek osztályozása Húsfeldolgozás alágazat lokális Moran I értékei alapján

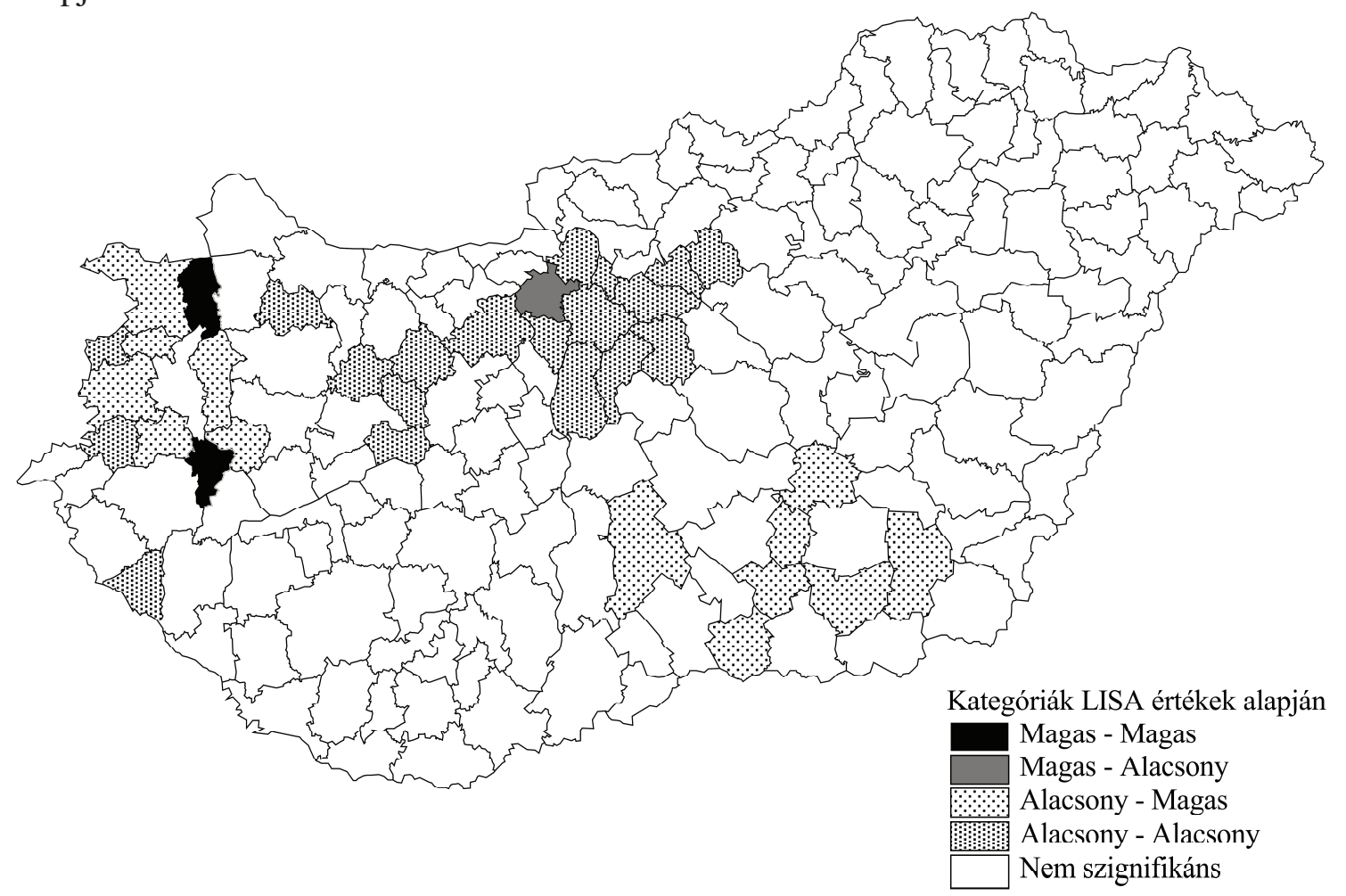

Forrás: saját szerkesztés

Megjegyzés: az osztályozás 5\%-os (pszeudo-)szignifikancia szintet figyelembe véve történt.

\subsubsection{A Közúti gépjármü, gépjármümotor alkatrészeinek gyártása alágazat}

Ez az alágazat magában foglalja a közúti gépjármű és a gépjármü-karosszéria különféle alkatrészeinek, tartozékainak, a motorkerékpár-motor alkatrészeinek gyártását, kivéve akkumulátorok és gépjármű villamos részeinek gyártását. Ez az alágazat az iparban és építőiparban foglalkoztatottak létszámához képest térben közepesen koncentrálódottnak mondható, viszont az összes foglalkoztatottak létszámához viszonyítva már erős térbeli koncentráció mutatható ki, ha Budapest adatait is figyelembe vesszük. Az alágazat erős térbeli autokorrelációt is mutat a vizsgálat minden esetében. A Herfindahl- index nem mutat ágazati koncentráltságot. E gyártási területen a vizsgálat időpontjában 229 vállalkozás működött, amelyeknek alkalmazásában közel negyvenezer fó állt. Az 19. táblázat mutatja az egyes mutatószám-értékeket. 
19. táblázat A Közúti gépjármü, gépjármümotor alkatrészeinek gyártása alágazat mutatószám-értékei

\begin{tabular}{|c|c|c|c|c|}
\hline $\begin{array}{c}\text { Közúti gépjármü, } \\
\text { gépjármümotor } \\
\text { alkatrészeinek } \\
\text { gyártása }\end{array}$ & $\begin{array}{c}\text { Iparban, építöiparban } \\
\text { foglalkoztatottakhoz } \\
\text { Budapesttel }\end{array}$ & $\begin{array}{c}\text { Összes } \\
\text { foglalkoztatotthoz } \\
\text { Budapesttel }\end{array}$ & $\begin{array}{c}\text { Iparban, építöiparban } \\
\text { foglalkoztatottakhoz } \\
\text { Budapest nélkül }\end{array}$ & $\begin{array}{c}\text { Összes } \\
\text { foglalkoztatotthoz } \\
\text { Budapest nélkül }\end{array}$ \\
\hline Moran index & 0,0737 & 0,0759 & 0,0767 & 0,0937 \\
\hline EG $\gamma$ mutató & 0,0326 & 0,0611 & 0,0179 & 0,0213 \\
\hline $\begin{array}{c}\text { Normalizált } \\
\text { Herfindahl index }\end{array}$ & \multicolumn{2}{|c|}{0,0416} & & 0,0426 \\
\hline
\end{tabular}

Forrás: saját szerkesztés

A 16. és 17. ábrákon látható az alágazat térbeli eloszlása. Viszonyítási alapnak az összes foglalkoztatottak kistérségi értékeit vettem és Budapest adatai is szerepelnek a számításokban. Budapest ebben az alágazatban sem torzít, hiszen ugyancsak jelentősen alulreprezentált $\left(L Q_{\text {Budapest }}=0,1\right)$.

16. ábra: A Közúti gépjármü, gépjárműmotor alkatrészeinek gyártása alágazat $L Q$ értékeinek térbeli eloszlása

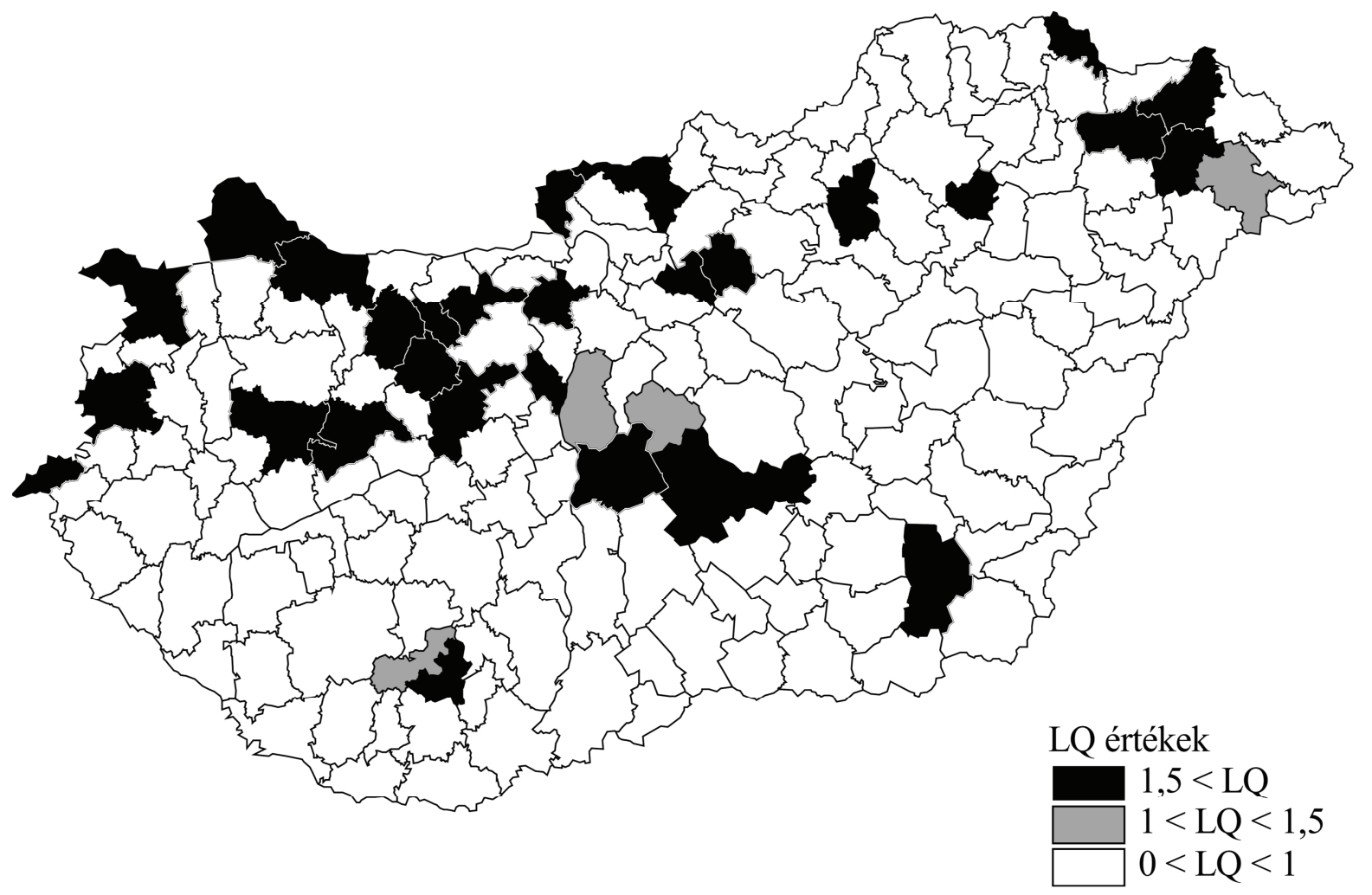

Forrás: saját szerkesztés

Már a globális mutatók (EG $\gamma$ és Moran I) alapján is térben kifejezetten koncentráltnak nevezhető ez az alágazat és erős pozitív autokorrelációt is mértünk. A lokális mutatók alapján pedig a következőket állapíthatjuk meg: 1,5-nél magasabb $L Q$ értékkel 28 kistérség rendelkezik. Ezek között 12 olyan van, amelyben több mint 1000 föt alkalmaznak az 
alágazatban: a Győri (8400 fö), a Székesfehérvári (5400fő), a Mosonmagyaróvári (2200fö), a Veszprémi, a Pilisvörösvári, az Orosházai, a Szombathelyi, a Sopron-Fertődi, a Móri, az Oroszlányi, az Egri és a Kecskeméti kistérségek.

17. ábra: Kistérségek osztályozása Közúti gépjármü, gépjármümotor alkatrészeinek gyártása alágazat lokális Moran I értékei alapján

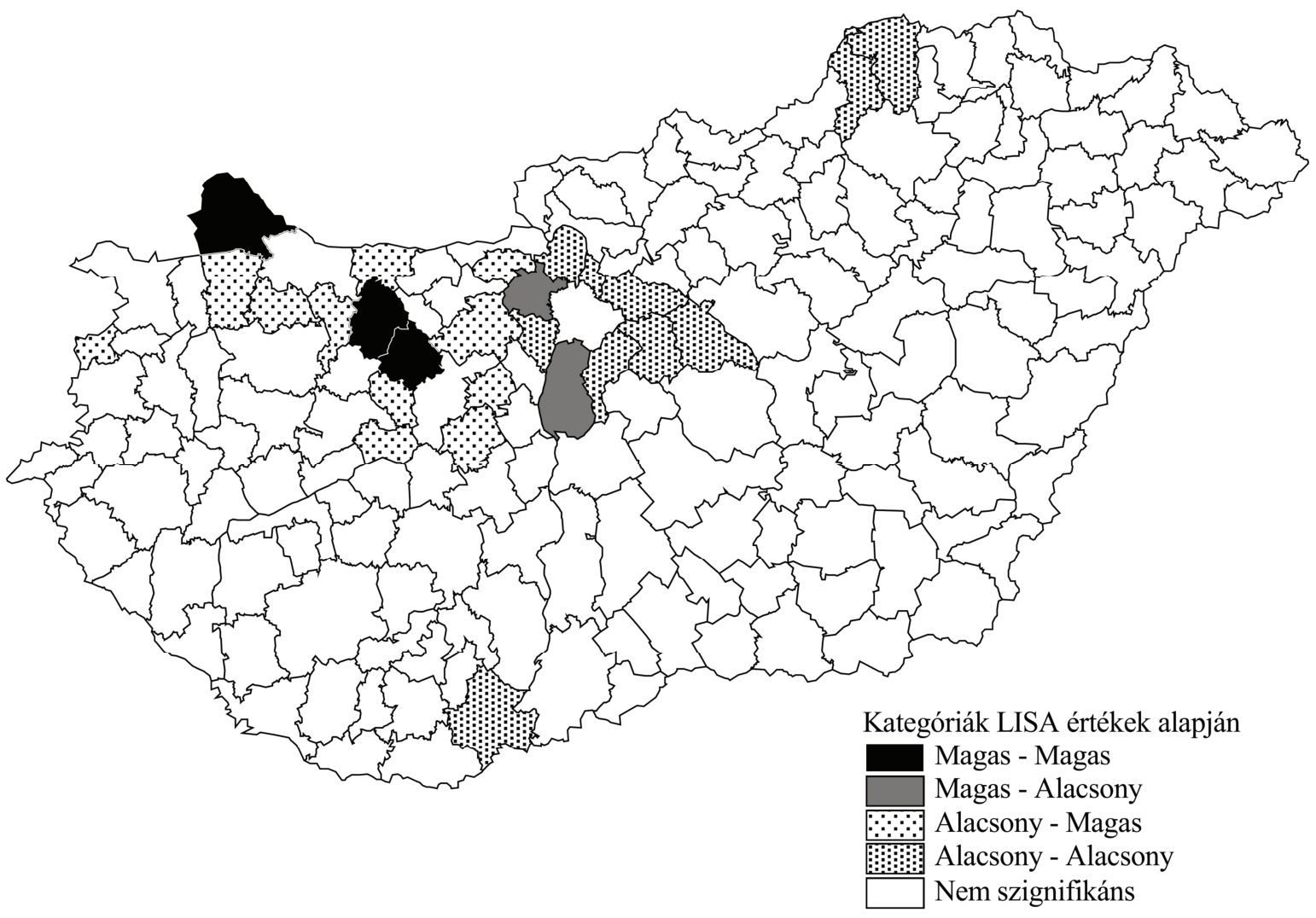

Forrás: saját szerkesztés

Megjegyzés: az osztályozás 5\%-os (pszeudo-)szignifikancia szintet figyelembe véve történt.

A LISA értékek három kistérség esetében mutatnak agglomerálódást, a Móri - itt és a környező kistérségekben több mint 8000 föt foglalkoztatnak -, a Mosonmagyaróvári - itt és a környező kistérségekben több mint 10000 föt foglalkoztatnak - és a Kisbéri - itt és a környező kistérségekben több mint 11000 föt foglalkoztatnak az alágazatban - kistérségek nevezhetők hot spotnak, elsősorban a nagyon sok főt alkalmazó Győri, illetve Székesfehérvári kistérséggel való szomszédságuk miatt. Az, hogy a Mosonmagyaróvári kistérség a H-H kategóriába tartozik, a Győri kistérség pedig nem, meglepő lehet, hiszen az utóbbiban kiemelkedően magas az alágazatban foglalkoztatottak száma (itt és a környező kistérségekben több mint 10000 föt alkalmaznak). Ennek az oka a LISA kiszámítási módjában, és abban 
rejlik, hogy a Mosonmagyaróvári kistérség az országhatáron helyezkedik el, így mindössze két szomszéddal rendelkezik, melyekben még átlagosan is nagyon koncentráltan van jelen ez az alágazat. A Győri kistérségnek nincs magas LISA értéke, bár az alágazati foglalkoztatottság itt kb. 8500 fö. Ez azért van, mert sok szomszédja lévén, a környező kistérségekben átlagosan nem kiemelkedően magas a koncentráció. A LISA kiszámítása során ugyanis csak a kistérség szomszédjainak értékeit vesszük figyelembe, a kistérségét magáét nem. Ebböl a szempontból a $G_{i}^{*}$ mutató szerencsésebb, mert kiszámításában szerepelnek mind a kistérségnek, mind a szomszédjainak adatértékei.

Magyarország három térségében találhatók cold spot-ok, a Pilisvörösvári és a Ráckevei kistérségek kivételével az összes Budapest környéki kistérség ilyen, ezen kívül a Mohácsi kistérség, valamint a Kazincbarcikai és Edelényi kistérségek együttese.

Összességében elmondható tehát, hogy ez az alágazat térben koncentrálódott és kistérségi határokon túlnyúló hajtóerők vonzzák egymás közelébe az alágazatban müködő vállalkozásokat.

\subsubsection{A feldolgozóipari alágazatok térbeli eloszlása - összegzés}

Magyarorzág 43 feldolgozóipari alágazatára végeztem vizsgálatokat kistérségi szinten a térbeli koncentráció lokális és globális mutatószámai (LQ és EG y), valamint az agglomeráció lokális és globális mutatószámai (Moran I és LISA) alapján. A mutatószámokat kiszámoltam Budapest adataival és azok nélkül is, valamint viszonyítási alapként használtam a nemzetgazdaság egészében foglalkoztatottak, illetve az iparban és építöiparban foglalkoztatottak térbeli eloszlását. A négyféle módon kiszámított mutatószám-sorok eloszlásának elemzésével és összevetésével teszteltem hipotéziseimet.

Megállapítható, hogy a Budapest hatás lényeges: a térbeli koncentráció mutatószámában (EG $\gamma$ ) szignifikáns az eltérés a Budapest adataival és az ezek nélkül kiszámított értékek között. Nem lényeges viszont a mutatószámok viszonyítási alapjának megváltoztatása, illetve abban az esetben, amikor mégis, a szignifikáns eltérés oka ugyancsak Budapest.

Megállapítható az is, hogy az feldolgozóipari alágazatok tudásintenzív volta befolyásolja a térbeli koncentráció mutatószámának (EG $\gamma$ ) értékét, a tudásintenzív alágazatok térben szignifikánsan koncentráltabbak a nem tudásintenzíveknél.

Eredményeim szerint a 43 alágazat között 12 olyan található, amelyek az alapesetben alapesetnek tekintem a Budapest adataival, az iparban és építőiparban foglalkoztatottak térbeli 
eloszlásához mérten számított mutatókat - térben erősen koncentráltak, e 12 alágazatban valószínűsíthető a vállalkozásokat egymás közelébe vonzó hatóerők léte. Ezen alágazatok között három olyat mutatott ki a vizsgálat, amelyek esetében a vonzóerők hatósugara meghaladja a kistérségi határokat. Az agglomeráció és koncentráció mérését célzó elemzésekben hasznos segítséget jelentenek a bemutatott mutatószámok, fontos azonban kiemelni, hogy kizárólag ezen értékek alapján nem lehet végső következtetést levonni.

\subsection{Tudásintenzív ágazatok}

Napjaink gazdasági környezete egyre gyorsabb változásokkal jellemezhető, amelyhez való alkalmazkodás rugalmasságot, tanulási készséget és gyors reagálást igényel. Ahhoz tehát, hogy a vállalatok a globális versenyben helytálljanak, szükséges a folyamatos innováció, amely elsősorban új vagy új minöségü termékek, szolgáltatások piacra vitelével valósulhat meg.

A fejlett országok gazdaságának legerőteljesebben fejlődő ágazatai - köszönhetően az információs technológiák elterjedésének és a tudásalapú gazdaság megerősödésének - a tudásintenzív ágazatok. Ezekben az ágazatokban valósul meg a legtöbb innováció, ezért szerkezetük, müködésük napjainkban jelentős érdeklődésre tarthat számot. A vizsgálatok arra is rámutattak, hogy az innováció és a térbeliség fogalma mind elméleti, mind gyakorlati szempontból mélyen kötődik egymáshoz.

Az Európai Unió is reagált ezekre a változásokra, így előtérbe került az innovatív gazdaságfejlesztés fogalma. Az Európai Bizottság 2010 júniusában elfogadta „Az intelligens, fenntartható és inkluzív növekedés stratégiája" címü stratégiai anyagát (EC 2010), melynek mindhárom prioritása kapcsolódik a tudásalapú, innovatív gazdasághoz.

A következőkben a hazai kistérségi empirikus vizsgálatbeli mutatókat és konkrét eredményeket ismertetem: két tudásintenzív feldolgozóipari alágazat, továbbá másik két szolgáltatási jellegű tudásintenzív alágazat térbeli eloszlását mutatom be részletesen.

\subsubsection{Az adatgyüjtés jellemzöi}

Avizsgálat 2009-es adatokra épül, így már 174 kistérség adataival számoltunk. A korábban említettek alapján Budapest különösen fontos szereplő minden magyar területi vizsgálatban, ezért a vizsgálatokat elvégeztem Budapest adatainak figyelembevételével, és azok nélkül is. Ennek hozadéka, mint már említettem, egyrészt az, hogy az ország többi 173 
kistérségének helyzetéről reálisabb képet alkothatunk, másrészt a kétféle vizsgálat eredményét összevetve Budapest szerepét is kiemelten elemezhetjük.

A vizsgálatban használt mutatószámok továbbá alkalmasak arra is, hogy felmérjük: a vizsgált ágazatban meglévő, a vállalatokat egymás közelébe vonzó hatóerők ágazatspecifikusak-e, avagy az egész ipari/szolgáltatási szektorban jelentkeznek.

Így az elemzés során a viszonyítási alapként használt $x_{i}$ értékeknél, amelyek a foglalkoztatottság egyes területi egységekre jutó hányadát jelentik, többféle adatot vettem figyelembe: elvégeztem a vizsgálatot mind az iparban/szolgáltatásokban foglalkoztatottak térbeli eloszlása, mind a nemzetgazdaság egészében foglalkoztatottak térbeli eloszlása alapján is. Ahogyan az a feldolgozóipari ágazatokra vonatkozó korábbi vizsgálatból már kiderült, a kétféle mérés között nincs lényeges különbség (II. hipotézis). Ezért, ha ezt külön nem hangsúlyozom, akkor csak azok az eredmények szerepelnek, amelyeket az adott szektorban foglalkoztatottak eloszlásához mérten számítottam ki.

Az egyes ágazatok egyenkénti vizsgálatánál olyan térképeket dolgoztam ki, amelyekben az egyes kistérségeket LQ és LISA index értékeik alapján 9 különböző osztályba soroltam (20. táblázat).

20. táblázat: A kistérségek lokális mutatók alapján történő osztályozása a térképeken és azok értelmezése

\begin{tabular}{|c|c|c|}
\hline LQ érték & $\begin{array}{l}\text { LISA index és p-érték } \\
\text { alapján }\end{array}$ & Jelentés \\
\hline $1,5<\mathrm{LQ}$ & Magas - Magas & $\begin{array}{l}\text { A kistérség erőteljesen specializált az ágazat szempontjából és a } \\
\text { környező kistérségben is átlagosan nagyobb arányban van jelen az } \\
\text { ágazat. }\end{array}$ \\
\hline $1,5<\mathrm{LQ}$ & Nem szignifikáns & $\begin{array}{l}\text { A kistérség erőteljesen specializált az ágazat szempontjából, de a } \\
\text { környező kistérségekben átlagosan nem jelentős sem az ágazat } \\
\text { túlzott jelenléte, sem a hiánya. }\end{array}$ \\
\hline $1,5<\mathrm{LQ}$ & Magas - Alacsony & $\begin{array}{l}\text { A kistérség erőteljesen specializált az ágazat szempontjából és a } \\
\text { környező kistérségekben az ágazat átlagosan hiányosan van jelen }\end{array}$ \\
\hline $1<\mathrm{LQ}<1,5$ & Magas - Magas & $\begin{array}{l}\text { A kistérség gyengén, de specializált az ágazat szempontjából és a } \\
\text { környező kistérségben is átlagosan nagyobb arányban van jelen az } \\
\text { ágazat. }\end{array}$ \\
\hline $1<\mathrm{LQ}<1,5$ & Nem szignifikáns & $\begin{array}{l}\text { A kistérség gyengén, de specializált az ágazat szempontjából, de a } \\
\text { környező kistérségekben átlagosan nem jelentős sem az ágazat } \\
\text { túlzott jelenléte, sem a hiánya. }\end{array}$ \\
\hline $1<\mathrm{LQ}<1,5$ & Magas - Alacsony & $\begin{array}{l}\text { A kistérség gyengén, de specializált az ágazat szempontjából és a } \\
\text { környező kistérségekben az ágazat átlagosan hiányosan van jelen. }\end{array}$ \\
\hline $\mathrm{LQ}<1$ & Alacsony - Magas & $\begin{array}{l}\text { Az ágazat a kistérségben a vártnál kisebb arányban van jelen, } \\
\text { miközben a környező kistérségekben a vártnál átlagosan nagyobb } \\
\text { arányban. }\end{array}$ \\
\hline $\mathrm{LQ}<1$ & Nem szignifikáns & $\begin{array}{l}\text { Az ágazat a kistérségben a vártnál kisebb arányban van jelen, de a } \\
\text { környező kistérségekben átlagosan nem jelentős sem az ágazat } \\
\text { túlzott jelenléte, sem a hiánya. }\end{array}$ \\
\hline $\mathrm{LQ}<1$ & Alacsony - Alacsony & $\begin{array}{l}\text { Az ágazat a kistérségben a vártnál kisebb arányban van jelen } \\
\text { éppen úgy, ahogyan a környező kistérségekben is. }\end{array}$ \\
\hline
\end{tabular}


A térképek ábrázolása egész oldalakon történt, mivel információtartalmuk a feldolgozóipari alágazatoknál két különböző térkép együttes információtartalmával egyezik meg. Az egyes mutatószámok értékei és az ágazati térképek megtalálhatók a melléklet II/2II/26. tábláin, a jelmagyarázatot pedig a II/1. tábla tartalmazza.

Az ágazatok tudásintenzitását az OECD által meghatározott technológiai színvonal alapján vettem figyelembe, amelyet az ágazatban felhasznált termelési tényezők, a technológia és a termék tudásintenzitásának segítségével definiáltak (21. táblázat). A technológiai színvonal alapján megkülönböztetünk (Eurostat 2009):

- high-tech feldolgozóipari ágazatokat (TEÁOR'08 2 számjegy alapján: 21, 26),

- medium-high-tech feldolgozóipari ágazatokat (20, 27, 28, 29, 30) és

- tudásintenzív szolgáltatási ágazatokat (50, 51, 58-66, 69-75, 78, 80, 84-88, 90-93).

A tudásintenzív szolgáltatások köre is tovább bontható:

- tudásintenzív piaci szolgáltatásokra (50-51, 69-70-71, 73-74, 78-80),

- tudásintenzív pénzügyi szolgáltatásokra (64-65-66) és

- high-tech tudásintenzív szolgáltatásokra (59-60-61-62-63 and 72).

21. táblázat: A tudásintenzív ágazatok OECD által definiált osztályozása

\begin{tabular}{|c|c|}
\hline High-tech feldolgozóipar & Medium-high-tech feldolgozóipar \\
\hline $\begin{array}{l}21 \text { Gyógyszergyártás } \\
26 \text { Számítógép, elektronikai, optikai } \\
\text { termék gyártása }\end{array}$ & $\begin{array}{l}20 \text { Vegyi anyag, termék gyártása } \\
27 \text { Villamos berendezés gyártása } \\
28 \text { Gép, gépi berendezés gyártása } \\
29 \text { Közúti jármú gyártása } \\
30 \text { Egyéb jármü gyártása }\end{array}$ \\
\hline \multicolumn{2}{|c|}{ Tudás intenzív szolgáltatások } \\
\hline $\begin{array}{l}50 \text { Vízi szállítás } \\
51 \text { Légi szállítás } \\
59 \text { Film, videó gyártás, televízió műsor } \\
\text { gyártása, hangfelvétel kiadás } \\
60 \text { Müsorösszeállítás, müsorszolgáltatás } \\
61 \text { Távközlés } \\
62 \text { Információ-technológiai szolgáltatás } \\
63 \text { Információs szolgáltatás } \\
64 \text { Pénzügyi közvetítés, kivéve } \\
\text { biztosítási, nyugdíjpénztári tevékenység } \\
65 \text { Biztosítás, viszontbiztosítás, } \\
\text { nyugdíjalapok (kivéve: kötelező } \\
\text { társadalombiztosítás) }\end{array}$ & $\begin{array}{l}\text { 66 Egyéb pénzügyi tevékenység } \\
\text { 69 Jogi, számviteli, adószakértői } \\
\text { tevékenység } \\
\mathbf{7 0} \text { Üzletvezetési, vezetői tanácsadás } \\
\mathbf{7 1} \text { Építészmérnöki tevékenység; } \\
\text { müszaki vizsgálat, elemzés } \\
\mathbf{7 2} \text { Tudományos kutatás, fejlesztés } \\
\mathbf{7 3} \text { Reklám, piackutatás } \\
\mathbf{7 4} \text { Egyéb szakmai, tudományos, } \\
\text { müszaki tevékenység } \\
\mathbf{7 8} \text { Munkaerópiaci szolgáltatás } \\
\mathbf{8 0} \text { Biztonsági, nyomozói tevékenység }\end{array}$ \\
\hline
\end{tabular}

Forrás: Eurostat (2009) alapján saját szerkesztés

$\mathrm{Az}$ empirikus elemzésben kistérségenként a tudásintenzív ipari és szolgáltatási ágazatokat a fötevékenységük alapján idetartozó cégek és foglalkoztatottjaik száma alapján vettük figyelembe (TEÁOR’08 felosztása alapján). A kistérségi foglalkoztatási adatok a KSH Területi Statisztikai Évkönyv 2007. kiadványból, illetve a KSH honlapjáról (www.ksh.hu), a 
2001-es népszámlálási adatokból, az egyes vállalatok adatai pedig a KSH Céginformációs adattárának (Cég-Kód-Tár) 2009/3-4-es kiadványából származtak..

Az egyes társas vállalkozások létszám, telephely és ágazati (TEÁOR’08 két számjegy) adatait a megfelelő kistérségekhez hozzárendelve végeztük a számításokat. A kistérségi szintü foglalkoztatottsági adatokat ágazatonként és létszám-kategóriánként gyüjtöttük ki.

Minden mutatószám kiszámításához pontos vállalati létszámadatokra lett volna szükség, ez azonban nem állt rendelkezésre, így ezeket becsülni kellett. A nemzetközi gyakorlat szerint feltételeztük, hogy a vállalati létszámok a létszám-kategóriákon belüli eloszlása egyenletes (Ellison-Glaeser 1997), így a Herfindahl-index kiszámításakor minden létszámadat esetében az adott létszám-kategórián belüli értékek számtani átlagával dolgoztunk.

A Moran-index számításához szükséges kistérségi szomszédsági mátrix, $W=$ adatait az időközben módosult területi beosztást követve 174 kistérség térbeli elhelyezkedése alapján „bástya” szomszédság alapján állítottuk össze, vagyis ha az $i$-edik és $j$-edik területi egységek közös határvonallal rendelkeznek, akkor értéke - ( az $i$-edik területi egység szomszédainak száma), különben 0 , valamint $\quad$ is 0 értéket kapott.

\subsubsection{A vizsgált ágazatok}

Az elemzés során kiszámítottuk az OECD által tudásintenzívnek tartott (21. táblázat) 7 feldolgozóipari és 18 szolgáltatási ágazatra az EG $\gamma$ és a Moran-index mutatóértékeket, megkülönböztetve a Budapesttel és nélküle végzett számításokat.

A Moran-index a $(-1 ; 1)$ intervallumban veheti fel az értékét. Mivel a Moran-index eloszlása nem ismert, ezért Monte-Carlo-módszer segítségével meghatároztuk a p-értéket is, amely az adott Moran-index érték az átlagtól való eltérésének szignifikancia szintjét jelzi.

A feldolgozóipari, illetve a szolgáltatási szektorban müködő tudásintenzív ágazatok között jelentős különbségeket tapasztalhatunk. Egyrészt Budapest a tudásintenzív szolgáltatási ágazatok szinte mindegyikében erős térbeli koncentrációt jelent, míg a tudásintenzív feldolgozóipari ágazatok esetében - egy két kivételtől eltekintve - sokkal kevésbé jelentős a főváros eme hatása. A Budapest adatai nélkül számolt EG $\gamma$ mutató értékek is nagyobb fokú térbeli koncentrációra utalnak a szolgáltatási ágazatok körében, mint a feldolgozóipari ágazatok esetében.

A Magyar Statisztikai évkönyv 2009-as kiadványa (KSH 2010) alapján megállapítottuk, hogy az összes azonos ágazatbeli vállalkozásoknak hány százaléka vezetett be az adott évben 
új eljárást vagy új terméket. A leginnovatívabb ágazatok a 20+21 Vegyi anyag, termék gyártása, gyógyszergyártás ágazatok együttese, amelyben müködő vállalkozások 47,2\%-a volt innovatív, és a 61-63 Távközlés, információtechnológiai és egyéb információs szolgáltatás ágazatok együttese, amelyben a müködő vállalkozások 40,2\%-a volt innovatív 2008-ban. Ezt követi a 29+30 Jármügyártás 36,5\%-kal, majd a 64-66 Pénzügyi, biztosítási tevékenység ágazat-együttes 33,3\%-kal.

A tudásintenzív ágazatok közül így kiemelve a leginnovatívabbakat, megvizsgáltuk az egyes szektorokban (ipar, illetve szolgáltatások) lévő tudásintenzív ágazatokat együttesen, majd kiemelten elemeztem az itt kiemelt ágazatok közül kettőt-kettőt a szektorokon belül.

Az ágazatokat két dimenzió mentén - térbeli koncentrálódás és agglomerálódás -, éppen úgy, ahogyan a feldolgozóipari alágazatok esetében is tettem, húsz osztályba soroltam. (22. és 23. táblázat).

1. A táblázat bal alsó osztályába a térben szétszórt és térben erősen negatívan autokorrelált ágazatok tartoznak, ami azt jelenti, hogy ezekben az ágazatokban a vállalkozások igyekeznek egymástól távol elhelyezkedni, a centripetális erők megléte kérdéses, azokat messze felülírják a centrifugális erők. Magyarországon sem Budapest adataival, sem azok nélkül nem található ilyen tudásintenzív ágazat.

2. A táblázat bal felső osztályába a térben erősen koncentrált és térben erősen negatívan autokorrelált ágazatok tartoznak, amelyekben a centripetális erök megléte erőteljesen kimutatható, azonban ezen hatóerők sugara nem mutat túl a kistérségi határokon. Magyarországon ilyen feldolgozóipari ágazatok nem találhatók, viszont a szolgáltatási ágazatok közül Budapest adataival ilyenek a 60 Müsorösszeállítás, müsorszolgáltatás, 64 Pénzügyi közvetités, 65 Biztosítás, viszontbiztosítás, nyugdíjalapok, 72 Tudományos kutatás, fejlesztés, 78 Munkaerőpiaci szolgáltatás ágazatok.

3. A táblázat jobb alsó osztályába a térben szétszórt és térben erősen autokorrelált ágazatok kerülnek, amelyekben a vállalkozások igyekeznek egymástól távol települni, azonban csak kevés vállalatról lévén szó (magas az ágazati koncentráció), sok kistérségben nincs jelen az ágazat, ezen kistérségek pedig térben összefüggő területeket alkotnak. Magyarországon sem Budapest adataival, sem azok nélkül nem található ilyen tudásintenzív ágazat.

4. A táblázat jobb felső osztályába a térben erősen koncentrált és térben erősen autokorrelált ágazatok kerültek. Ezekben a vállalatokat egymás közelébe vonzó centripetális erők megléte erőteljesen kimutatható, és ezen erők sugara túllépi a kistérségi határokat. Csak Budapest adataival található ilyen, vagyis ezen ágazatok 
esetén az agglomerálódás Budapesten és a szomszédos kistérségekbe történik. Az egyetlen ilyen tudásintenzív feldolgozóipari ágazat a 30 Egyéb jármü gyártása, és van még hat tudásintenzív szolgáltatási ágazat: 61 Távközlés, 62 Információtechnológiai szolgáltatás, 70 Üzletvezetési, vezetői tanácsadás, 71 Építészmérnöki tevékenység; müszaki vizsgálat, elemzés, 74 Egyéb szakmai, tudományos, müszaki tevékenység, 80 Biztonsági, nyomozói tevékenység.

22. táblázat: A tudásintenzív ágazatok térbeli koncentrációja és agglomerációja Budapest adatainak figyelembevételével

\begin{tabular}{|c|c|c|c|c|c|c|}
\hline & \multicolumn{5}{|c|}{ térbeli autokorreláció } \\
\hline & & erôs negatív & $\begin{array}{l}\text { gyenge } \\
\text { negatív }\end{array}$ & nincs & gyenge pozitív & erős pozitív \\
\hline \multirow{4}{*}{ 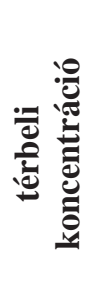 } & erős & $\begin{array}{c}60,64,65 \\
72,78\end{array}$ & & $\begin{array}{c}21,58,63,66 \\
69,73\end{array}$ & 59 & $\begin{array}{c}\mathbf{3 0}, 61,62,70, \\
71,74,80\end{array}$ \\
\hline & közepes & & 20 & 29 & & \\
\hline & gyenge & & & $26,27,28,50$ & & 51 \\
\hline & \begin{tabular}{|l} 
térben \\
szétszórt
\end{tabular} & & & & & \\
\hline
\end{tabular}

Forrás: saját szerkesztés

Megjegyzések: az osztályokba sorolás az EG $\gamma$ értékek és a Moran index értékekhez tartozó p-értékek alapján történt a félkövér számok a high-tech és medium-high-tech feldolgozóipari ágazatokat jelölik.

23. táblázat: A tudásintenzív ágazatok térbeli koncentrációja és agglomerációja Budapest adatainak figyelmen kívül hagyása mellett

\begin{tabular}{|c|c|c|c|c|c|c|}
\hline & \multicolumn{5}{|c|}{ térbeli autokorreláció } \\
\hline & & erős negatív & $\begin{array}{l}\text { gyenge } \\
\text { negatív }\end{array}$ & nincs & gyenge pozitív & erös pozitív \\
\hline \multirow{4}{*}{$\begin{array}{r} \\
\end{array}$} & erős & & & 51,61 & & \\
\hline & közepes & & & 20,27 & & \\
\hline & gyenge & & & 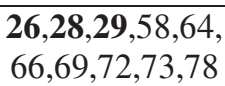 & 50,71 & $\begin{array}{c}59,62,63,70, \\
74,80\end{array}$ \\
\hline & $\begin{array}{l}\text { térben } \\
\text { szétszórt }\end{array}$ & & & $\mathbf{2 1 , 3 0 , 6 0 , 6 5}$ & & \\
\hline
\end{tabular}

Forrás: saját szerkesztés

Megjegyzések: az osztályokba sorolás az EG $\gamma$ értékek és a Moran index értékekhez tartozó p-értékek alapján történt; a félkövér számok a high-tech és medium-high-tech feldolgozóipari ágazatokat jelölik.

\subsubsection{Tudásintenzív feldolgozóipari ágazatok térbeli eloszlása}

Az innovatív ágazatok térbeli eloszlása a bevezetőben említettek miatt feltehetően nagyfokú egyenlőtlenségeket mutat. Természetesen a koncentrálódás és agglomerálódás mértékét meghatározza az is, hogy milyen a térfelosztási szint mellett mérjük. 
$\mathrm{Az}$ egyes tudásintenzív feldolgozóipari ágazatok vizsgálatának eredményeiböl megállapítható, hogy az EG $\gamma$ mutató értéke Budapest adatainak figyelembevétele esetén minden ágazatnál pozitív értéket vesz fel, vagyis koncentrálódás figyelhető meg (24. táblázat). A két leginkább koncentrálódott ágazat a 21 Gyógyszergyártás és a 30 Egyéb jármü gyártása ágazatok, amelyek esetében egyértelmü, hogy koncentráltságukat Budapest okozza, hiszen EG $\gamma$ értékeik Budapest adatainak kihagyása esetén negatívak. Tehát ebben az esetben mindkét ágazat - ha minimális mértékben is, de - térben szétszórtnak nevezhető.

24. táblázat: Térbeli koncentráció a tudásintenzív feldolgozóipari ágazatokban

\begin{tabular}{|c|l|c|c|}
\hline \multirow{2}{*}{$\begin{array}{c}\text { Térbeli } \\
\text { koncent- } \\
\text { ráltság }\end{array}$} & \multicolumn{1}{|c|}{ Feldolgozóipari ágazat } & \multicolumn{2}{|c|}{ EG $\gamma$ érték } \\
\cline { 3 - 4 } & \multicolumn{1}{|c|}{ Budapesttel } & Budapest nélküil \\
\hline \multirow{2}{*}{ erős } & $\mathbf{2 1 ~ G y o ́ g y s z e r g y a ́ r t a ́ s ~}$ & 0,397 & $-0,009$ \\
\cline { 2 - 4 } & $\mathbf{3 0}$ Egyéb jármú gyártása & 0,057 & $-0,001$ \\
\hline \multirow{2}{*}{ közepes } & $\mathbf{2 0}$ Vegyi anyag, termék gyártása & 0,047 & 0,038 \\
\cline { 2 - 4 } & $\mathbf{2 9}$ Közúti jármú gyártása & 0,024 & 0,017 \\
\hline \multirow{2}{*}{ gyenge } & $\mathbf{2 7}$ Villamos berendezés gyártása & 0,018 & 0,024 \\
\cline { 2 - 4 } & $\mathbf{2 8}$ Gép, gépi berendezés gyártása & 0,009 & 0,001 \\
\cline { 2 - 4 } & $\begin{array}{l}\text { 26 Számítógép, elektronikai, optikai termék } \\
\text { gyártása }\end{array}$ & 0,009 & 0,012 \\
\hline
\end{tabular}

Forrás: saját szerkesztés

A Moran-index értékek esetében inkább megoszlanak az ágazatok (25. táblázat), erősen agglomerálódottnak csak a 30 Egyéb jármü gyártása ágazat nevezhető. Tehát az ágazatbeli vállalatok tömörülését létrehozó erők csak ezen ágazat esetben mutatnak túl a kistérségi határokon, sőt a Budapest adatai nélkül számított autokorreláció nem szignifikáns, vagyis a kistérségi határon átnyúló erőkről csak Budapest esetében beszélhetünk. A további ágazatok esetében nem szignifikáns az autokorreláció. Az is megállapítható, hogy a két különböző tudásintenzitású ágazatcsoport (high-tech: 21,26, illetve medium high-tech: 20,27,28,29,30 ágazatok) között nincs szignifikáns különbség sem a térbeli koncentrációt, sem az agglomerációt tekintve. 
25. táblázat: Agglomeráció a tudásintenzív feldolgozóipari ágazatokban

\begin{tabular}{|c|c|c|c|}
\hline \multirow{2}{*}{$\begin{array}{l}\text { Autokor- } \\
\text { reláció }\end{array}$} & \multirow{2}{*}{ Feldolgozóipari ágazat } & \multicolumn{2}{|c|}{ p érték } \\
\hline & & Budapesttel & Budapest nélkül \\
\hline $\begin{array}{c}\text { erős } \\
\text { pozitív }\end{array}$ & 30 Egyéb jármű gyártása & 0,025 & 0,248 \\
\hline \multirow{5}{*}{ nincs } & 29 Közúti jármü gyártása & 0,146 & 0,127 \\
\hline & 27 Villamos berendezés gyártása & 0,312 & 0,308 \\
\hline & $\begin{array}{l}26 \text { Számítógép, elektronikai, optikai termék } \\
\text { gyártása }\end{array}$ & 0,536 & 0,561 \\
\hline & 28 Gép, gépi berendezés gyártása & 0,44 & 0,343 \\
\hline & 21 Gyógyszergyártás & 0,214 & 0,161 \\
\hline $\begin{array}{l}\text { gyenge } \\
\text { negatív }\end{array}$ & 20 Vegyi anyag, termék gyártása & 0,073 & 0,065 \\
\hline
\end{tabular}

Forrás: saját szerkesztés

\subsubsection{Vegyi anyag, termék gyártása}

Ebbe az ágazatba tartozik minden vegyipari eljárásokkal történő átalakítás, valamint bármilyen termék szerves és szervetlen nyersanyagokból történő előállítása. Az ágazatban, a vizsgálat időpontjában 16370 fő dolgozott, ezek közül 4640 Budapesten állt alkalmazásban (26. táblázat).

26. táblázat: Vegyi anyag, termék gyártása ágazat mutatószám-értékei

\begin{tabular}{|l|c|c|c|c|}
\hline & \multicolumn{2}{|c|}{ Budapesttel } & \multicolumn{2}{c|}{ Budapest nélkül } \\
\hline Átlagos méret (fó) & \multicolumn{2}{|c|}{36} & \multicolumn{2}{c|}{49} \\
\hline $\begin{array}{l}\text { Vállalkozások száma } \\
(\mathrm{db})\end{array}$ & \multicolumn{2}{|c|}{657} & \multicolumn{2}{c|}{0,115} \\
\hline Herfindahl index ${ }^{31}\left(\mathrm{H}^{*}\right)$ & \multicolumn{2}{|c|}{0,063} & $\begin{array}{c}\text { Iparban, építö- } \\
\text { iparban foglal- } \\
\text { koztatottakhoz }\end{array}$ & $\begin{array}{c}\text { Összes foglal- } \\
\text { koztatotthoz }\end{array}$ \\
\hline & $\begin{array}{l}\text { Iparban, építö- } \\
\text { iparban foglal- } \\
\text { koztatottakhoz }\end{array}$ & foglalkoztatotthoz & $-0,032$ & $-0,037$ \\
\hline Moran-index & $-0,036$ & $-0,045$ & 0,065 & 0,038 \\
\hline p érték & 0,073 & 0,021 & 0,038 & 0,041 \\
\hline EG $\gamma$ mutató & 0,047 & 0,032 & & \\
\hline
\end{tabular}

Forrás: saját szerkesztés

31 Megjegyezzük, hogy a Herfindahl index értéke 1/N-től 1-ig terjedhet, ezért az összehasonlíthatóság kedvéért ennek módosított változatát, a normalizált Herfindahl indexet $\left(\mathrm{H}^{*}\right)$ használtuk, melynek értéke 0-tól 1ig terjedhet. 
18. ábra A Vegyi anyag, termék gyártása ágazat LQ és LISA index értékei, Budapest adatainak figyelembevételével

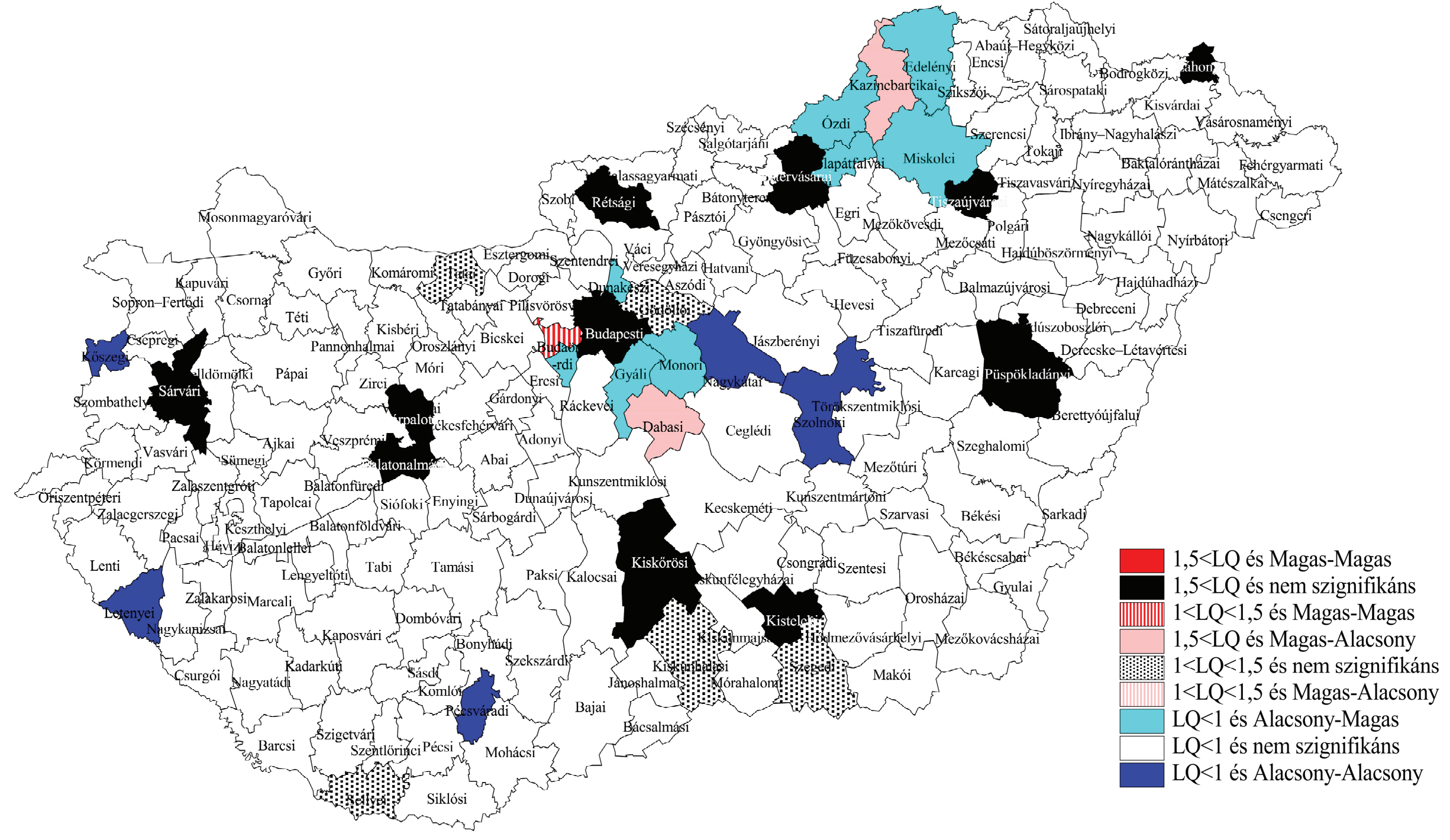

Forrás: saját szerkesztés

Megjegyzés: az iparban és építőiparban foglalkoztatottakhoz viszonyítva. 
19. ábra: A Vegyi anyag, termék gyártása ágazat LQ és LISA index értékei Budapest adatainak figyelembevétele nélkül

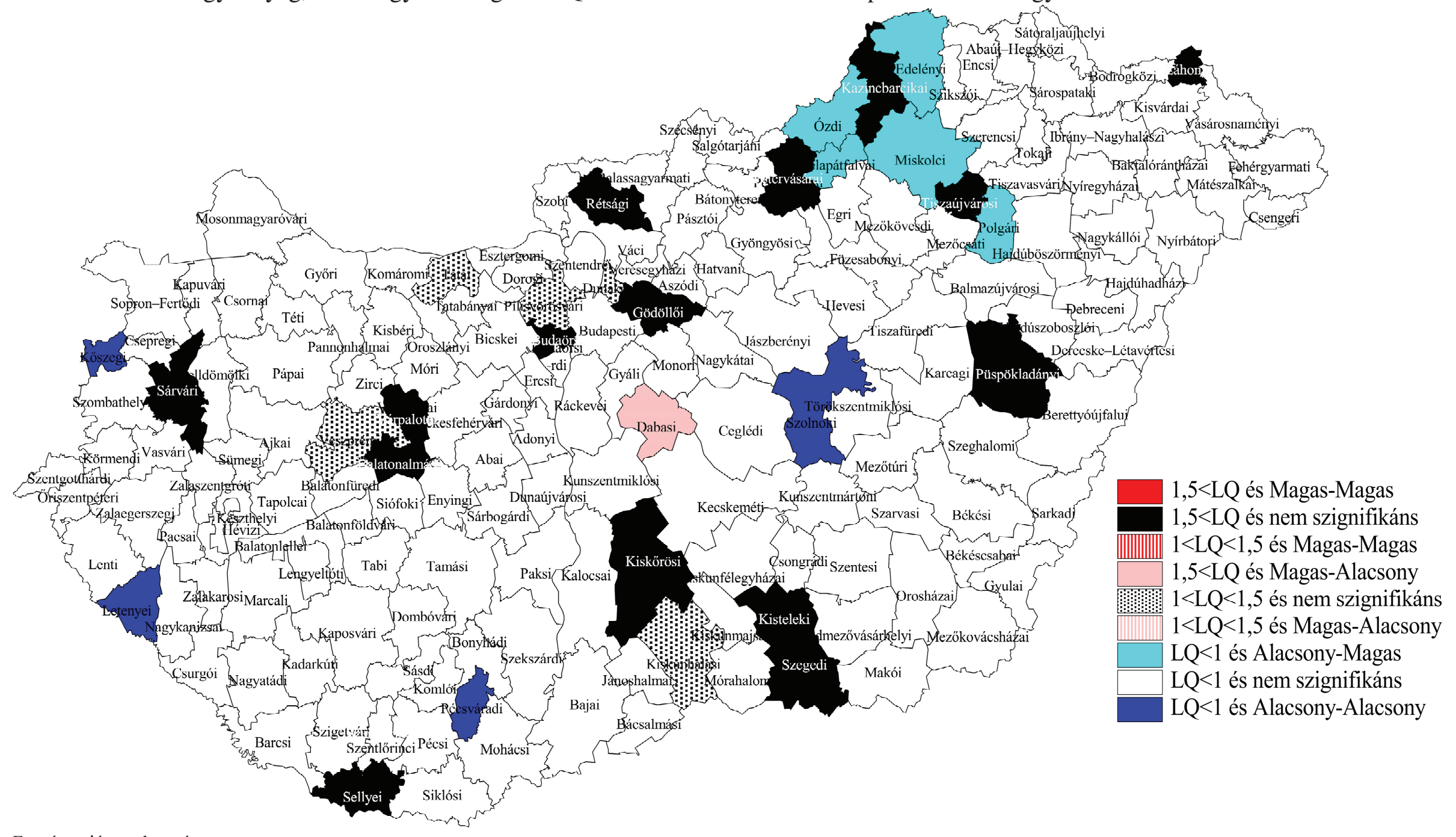

Forrás: saját szerkesztés

Megjegyzés: az iparban és építöiparban foglalkoztatottakhoz viszonyítva 
Bármelyik viszonyítási alapot tekintjük is (szektorhoz, illetve összes foglalkoztatotthoz), és Budapest adataitól függetlenül is - térben közepesen koncentrált az ágazat az EG $\gamma$ mutató értékek alapján (24. táblázat). A Herfindahl index azt mutatja $\left(\mathrm{H}^{*}=\right.$ 0,115), hogy Budapesten kívül az ágazati koncentráció fennáll, ha nem is erőteljesen. A Moran-index értékéből pedig inkább negatív autokorreláció olvasható ki, tehát a térbeli koncentrációt létrehozó erők nem nyúlnak túl a kistérségi határokon, sőt, inkább egymástól elszigeteltek azok a kistérségek, amelyekben ez az ágazat jelen van.

Bár Budapest lokális Moran-index értéke alapján nem mondható hot-spotnak, mégis itt, a Budaörsi, valamint a Gödöllői kistérségben foglalkoztatják az ágazatban dolgozók 30\%-át. Az adatok alapján kijelenthető, hogy a vegyipari tevékenység egyes kistérségekhez köthető, ezek elhelyezkedése azonban többnyire nem összefüggő. Ez alól csak Budapest kivétel, azonban itt sem jelentős az agglomerálódás (18-19. ábra).

\subsubsection{Gyógyszergyártás}

Ebbe az ágazatba tartozik a gyógyszeralapanyag és a gyógyszerkészítmény gyártása, valamint a gyógyászati célú vegyi és növényi eredetű termékek előállítása. Az ágazatban, a vizsgálat időpontjában 16350 fő dolgozott, ezek közül 13290 fő Budapesten állt alkalmazásban, tehát a foglalkoztatottak 81\%-a Budapesten található. Ez igen jelentős Budapest központúságot jelent, amit az EG $\gamma$ mutató rendkívül magas értéke $(E G \gamma=0,397)$ is igazol, különösen a Budapest adatainak kihagyásával számított értékkel (EG $\gamma=-0,009)$ való összehasonlítás után (27. táblázat). Ez utóbbi arra enged következtetni, hogy az ágazat térben kifejezetten szóródott Budapesten kívül.

27. táblázat: A Gyógyszergyártás ágazat mutatószám-értékei

\begin{tabular}{|l|c|c|c|c|}
\hline & \multicolumn{2}{|c|}{ Budapesttel } & \multicolumn{2}{c|}{ Budapest nélkül } \\
\hline Átlagos méret (fö) & \multicolumn{2}{|c|}{186} & \multicolumn{2}{c|}{65} \\
\hline Vállalkozások száma (db) & \multicolumn{2}{|c|}{112} & \multicolumn{2}{c|}{0,254} \\
\hline Herfindahl index (H*) & \multicolumn{2}{|c|}{0,192} & $\begin{array}{c}\text { Iparban, építő- } \\
\text { iparban foglal- } \\
\text { koztatottakhoz }\end{array}$ & $\begin{array}{c}\text { Összes foglal- } \\
\text { koztatotthoz }\end{array}$ \\
\hline Moran-index & $\begin{array}{c}\text { Iparban, építő- } \\
\text { iparban foglal- } \\
\text { koztatottakhoz }\end{array}$ & $\begin{array}{c}\text { Összes foglal- } \\
\text { koztatotthoz }\end{array}$ & 0,004 & 0,003 \\
\hline p érték & $-0,011$ & $-0,016$ & 0,161 & 0,171 \\
\hline EG $\gamma$ mutató & 0,214 & 0,082 & $-0,009$ & $-0,018$ \\
\hline
\end{tabular}

Forrás: saját szerkesztés 
20. ábra: A Gyógyszergyártás ágazat LQ és LISA index értékei Budapest adatainak figyelembevételével

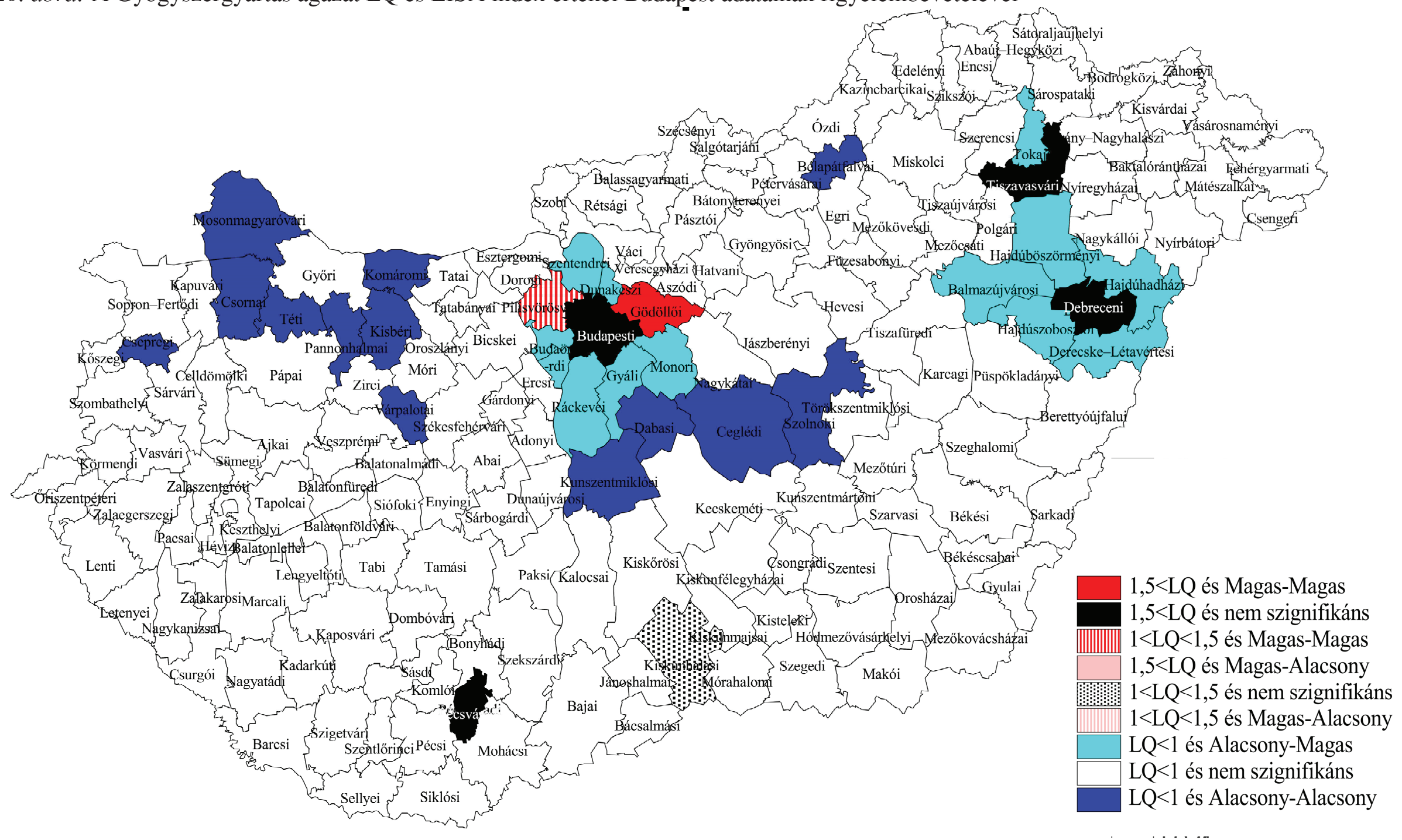

Forrás: saját szerkesztés

Megjegyzés: az iparban és építőiparban foglalkoztatottakhoz viszonyítva. 
21. ábra: A Gyógyszergyártás ágazat LQ és LISA index értékei Budapest adatainak figyelembevétele nélkül

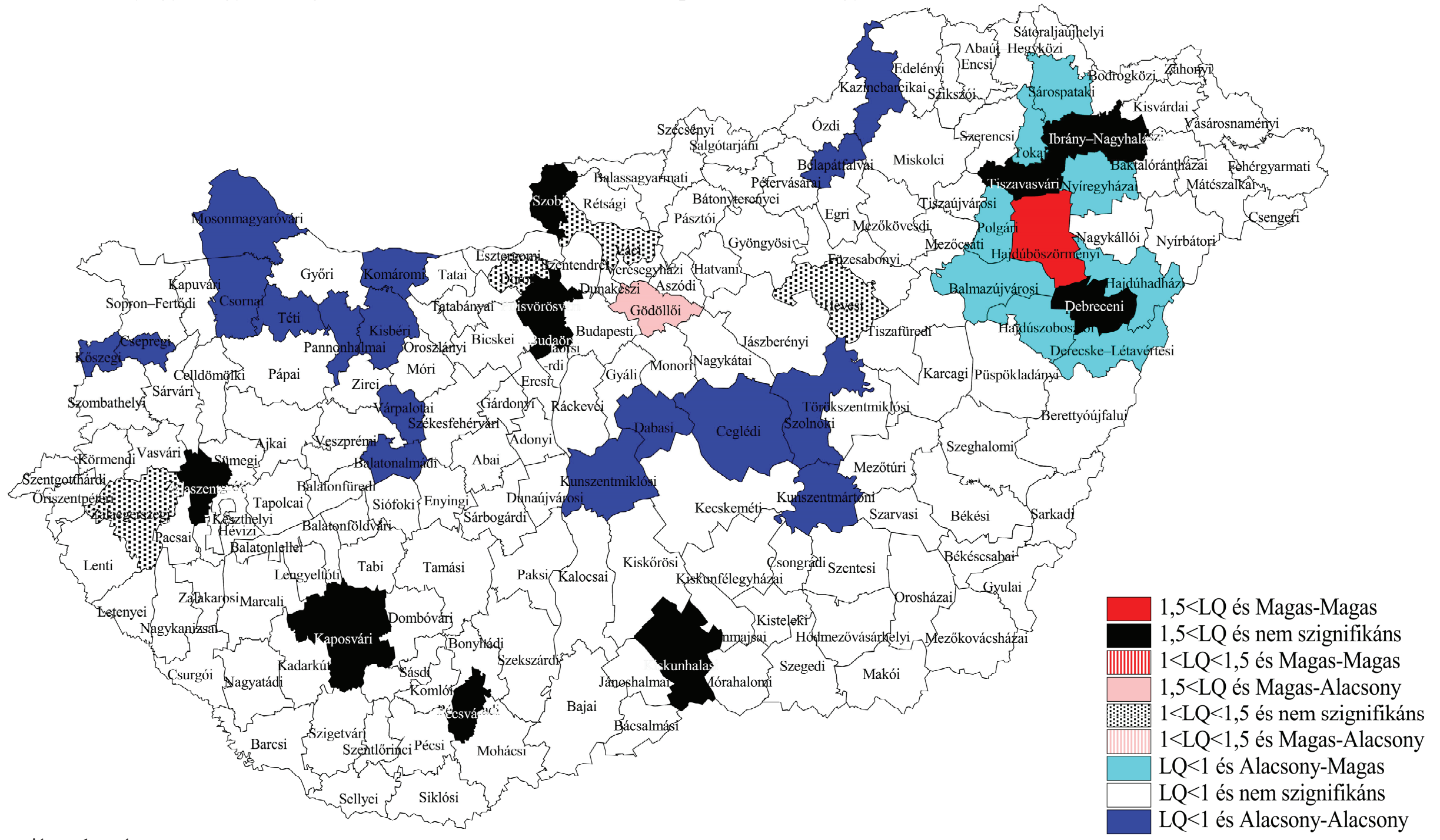

Forrás: saját szerkesztés

Megjegyzés: az iparban és építőiparban foglalkoztatottakhoz viszonyítva. 
A Herfindahl index magas értéke alapján arra a következtetésre jutunk, hogy az ágazat nemcsak térben, hanem ágazatilag is erőteljesen koncentrálódott. A Moran-index értéke szerint az ágazat csak az összes foglalkoztatottak eloszlásához mérten, Budapest adataival együtt nevezhető gyengén negatívan autokorreláltnak. A többi számítási mód mellett nincs szignifikáns autokorreláció, tehát a térbeli koncentrációt létrehozó erők nem nyúlnak túl a kistérségi határokon.

Két olyan térsége van az országnak, ahol számottevő gyógyszeripari tevékenység folyik (20. és 21. ábra). Egyrészt Budapesten és két szomszédos kistérségben: a Gödöllöi és a Pilisvörösvári kistérségekben (itt összesen 13800 föt foglalkoztattak az ágazatban). Másrészt a Debreceni, a Hajdúböszörményi, a Tiszavasvári és az Ibrány-Nagyhalászi kistérségek alkotta együttesben (itt összesen kb. 2000 fö volt a foglalkoztatottak száma).

\subsubsection{Szolgáltatások}

Az általam vizsgált tudásintenzív szolgáltatási ágazatok közül két kivétellel (51 Légi szállitás és 50 Vizi szállítás) az összes erősen szignifikánsan koncentrált, de csak abban az esetben, ha Budapest adatait számításba vesszük. Amennyiben Budapest adataitól eltekintünk, a kép sokat változik: csak a 61 Távközlés és az 51 Légi szállitás ágazatok koncentráltak, a többi ágazat nem. Sőt a Budapesti kistérségben nagyon koncentráltan jelenlévő 65 Biztosítás, viszontbiztositás, nyugdíjalapok és 60 Müsorösszeállítás, müsorszolgáltatás ágazatokban müködő vállalkozások még inkább gyengén szétszórtnak is mutatkoznak a fövároson kívül (28. táblázat).

A szolgáltatási ágazatok között - a feldolgozóiparral szemben - már bőven találunk olyanokat, amelyek - Budapest adataival számítva - erősen koncentráltnak és erősen agglomeráltnak nevezhetők (28. és 29. táblázat). Ilyenek a 61 Távközlés, a 62 Információtechnológiai szolgáltatás, a 70 Üzletvezetési, vezetöi tanácsadás, a 71 Építészmérnöki tevékenység, müszaki vizsgálat, elemzés, a 74 Egyéb szakmai, tudományos, müszaki tevékenység és a 80 Biztonsági, nyomozói tevékenység ágazatok. Ezek tehát - elsősorban Budapesten és öt körülvevő kistérségekben való - koncentrált jelenlétüket olyan centripetális erők meglétének köszönhetik, amelyek túlmutatnak a kistérségi határokon. 
28. táblázat: Térbeli koncentráció a tudásintenzív szolgáltatási ágazatokban

\begin{tabular}{|c|c|c|c|}
\hline \multirow{2}{*}{$\begin{array}{l}\text { Térbeli } \\
\text { koncent- } \\
\text { ráltság }\end{array}$} & \multirow[b]{2}{*}{ szolgáltatási ágazat } & \multicolumn{2}{|l|}{ EG $\gamma$ érték } \\
\hline & & Budapesttel & Budapest nélküil \\
\hline \multirow{16}{*}{ Erős } & 65 Biztosítás, viszontbiztosítás, nyugdíjalapok & 0,565 & $-0,031$ \\
\hline & 60 Műsorösszeállítás, müsorszolgáltatás & 0,386 & $-0,09$ \\
\hline & 64 Pénzügyi közvetítés, & 0,349 & 0 \\
\hline & 63 Információs szolgáltatás & 0,326 & 0,006 \\
\hline & $\begin{array}{l}59 \text { Film, videó gyártás, televízió-müsor gyártása, } \\
\text { hangfelvétel kiadás }\end{array}$ & 0,31 & 0,013 \\
\hline & 62 Információtech-nológiai szolgáltatás & 0,273 & 0,01 \\
\hline & 72 Tudományos kutatás, fejlesztés & 0,209 & 0,018 \\
\hline & 73 Reklám, piackutatás & 0,189 & 0,005 \\
\hline & 70 Üzletvezetési, vezetői tanácsadás & 0,184 & 0,008 \\
\hline & 78 Munkaerőpiaci szolgáltatás & 0,181 & 0,011 \\
\hline & 61 Távközlés & 0,167 & 0,236 \\
\hline & 66 Egyéb pénzügyi tevékenység & 0,132 & 0,003 \\
\hline & 80 Biztonsági, nyomozói tevékenység & 0,102 & 0,004 \\
\hline & $\begin{array}{l}71 \text { Építészmérnöki tevékenység; műsza-ki vizsgálat, } \\
\text { elemzés }\end{array}$ & 0,098 & 0,004 \\
\hline & 69 Jogi, számviteli, adószakértői tevékenység & 0,088 & 0,002 \\
\hline & 74 Egyéb szakmai, tudományos, műszaki tevékenység & 0,059 & 0,004 \\
\hline \multirow{2}{*}{ Gyenge } & 51 Légi szállítás & 0,014 & 0,465 \\
\hline & 50 Vízi szállítás & 0,011 & 0,009 \\
\hline
\end{tabular}

Forrás: saját szerkesztés

Ez utóbbi hat ágazat közül négy - a 62 Információ-technológiai szolgáltatás, a 70 Üzletvezetési, vezetői tanácsadás, a 74 Egyéb szakmai, tudományos, müszaki tevékenység és a 80 Biztonsági, nyomozói tevékenység ágazatok - olyan, hogy Budapest adatainak figyelembevétele nélkül is legalább gyengén koncentráltak és erősen agglomeráltak. Ebből arra következtethetünk, hogy nem csak a Budapesti kistérségben, hanem más kistérségek környezetében is magasabb az ezen ágazatokban müködő vállalkozások koncentrációja - ezt az LQ értékek, illetve a lokális Moran-index értékek alapján tudnánk közelebbröl megvizsgálni. A másik két ágazat - a 61 Távközlés és a 71 Épitészmérnöki tevékenység, müszaki vizsgálat, elemzés - viszont nem agglomerálódik Budapest kihagyásával, tehát ezekben az esetekben csak Budapest és környéke a koncentráció forrása. 
29. táblázat: Agglomeráció a tudásintenzív szolgáltatási ágazatokban.

\begin{tabular}{|c|c|c|c|}
\hline \multirow{2}{*}{$\begin{array}{l}\text { Autokor- } \\
\text { reláció }\end{array}$} & \multirow{2}{*}{ szolgáltatási ágazat } & \multicolumn{2}{|l|}{ p érték } \\
\hline & & Budapesttel & Budapest nélküil \\
\hline \multirow{7}{*}{$\begin{array}{l}\text { Erős } \\
\text { pozitív }\end{array}$} & 80 Biztonsági, nyo-mozói tevékenység & 0,002 & 0,027 \\
\hline & $\begin{array}{l}71 \text { Építészmérnöki tevékenység; müszaki vizsgálat, } \\
\text { elemzés }\end{array}$ & 0,007 & 0,06 \\
\hline & 74 Egyéb szakmai, tudományos, müszaki tevékenység & 0,01 & 0,003 \\
\hline & 62 Információtech-nológiai szolgáltatás & 0,019 & 0,002 \\
\hline & 70 Üzletvezetési, vezetői tanácsadás & 0,031 & 0,005 \\
\hline & 61 Távközlés & 0,033 & 0,186 \\
\hline & 51 Légi szállítás & 0,034 & 0,185 \\
\hline $\begin{array}{l}\text { Gyenge } \\
\text { pozitív }\end{array}$ & $\begin{array}{l}59 \text { Film, videó gyártás, televízió-müsor gyártása, } \\
\text { hangfelvétel kiadás }\end{array}$ & 0,068 & 0,001 \\
\hline \multirow{5}{*}{ nincs } & 50 Vízi szállítás & 0,144 & 0,099 \\
\hline & 69 Jogi, számviteli, adószakértői tevé-kenység & 0,581 & 0,52 \\
\hline & 66 Egyéb pénzügyi tevékenység & 0,327 & 0,173 \\
\hline & 63 Információs szolgáltatás & 0,17 & 0,005 \\
\hline & 73 Reklám, piackutatás & 0,119 & 0,624 \\
\hline \multirow{5}{*}{$\begin{array}{l}\text { erősen } \\
\text { negatív }\end{array}$} & 72 Tudományos ku-tatás, fejlesztés & 0,04 & 0,214 \\
\hline & 78 Munkaerőpiaci szolgáltatás & 0,004 & 0,228 \\
\hline & 65 Biztosítás, viszontbiztosítás, nyugdíjalapok & 0,002 & 0,472 \\
\hline & 64 Pénzügyi közvetítés, & 0,003 & 0,494 \\
\hline & 60 Müsorösszeállítás, műsorszolgáltatás & 0,002 & 0,37 \\
\hline
\end{tabular}

Forrás: saját szerkesztés

E négy ágazaton kívuil van még kettő - az 59 Film, videó gyártás, televíziómüsor gyártása, hangfelvétel kiadás és a 63 Információs szolgáltatás ágazatok - amelyek Budapest adatai nélkül erősen agglomeráltak, de nem szignifikánsan koncentráltak, esetükben a Budapesti kistérségen kívül erősen hasonlóak a szomszédos kistérségek. Itt viszont abban, hogy alacsony foglalkoztatottságot találunk, ez is további LQ és lokális Moran-index vizsgálatokat igényelne.

\subsubsection{Információtechnológiai szolgáltatás}

Ebbe az ágazatba tartozik az információ-technológiai területen nyújtandó szakértői tevékenység: szoftver írása, módosítása, tesztelése és ezek támogató szolgáltatása; a számítógéphardvert, szoftvert és kommunikációs technológiát integráló számítógépes 
rendszerek tervezése; kihelyezett számítógépes rendszer és/vagy adatfeldolgozási rendszer üzemeltetése (az ügyfél helyszínén) és egyéb számítógéppel kapcsolatos szakértői vagy technikusi tevékenység.

Az ágazatban, a vizsgálat időpontjában közel 39000 fő dolgozott, ezek közül 28300 főt a fővárosban foglalkoztattak, így a foglalkoztatottak 73\%-a budapesti vállalkozásnál állt alkalmazásban. Ez jelentős Budapest központúságot jelent, amit az EG $\gamma$ mutató magas értéke (EG $\gamma=0,273$ ) is igazol (30. táblázat). Ha Budapest adatai nélkül tekintjük, egy enyhe fokú térbeli koncentrációt tapasztalhatunk, miközben a Herfindahl index alacsony értéke és a vállalkozások átlagos mérete az ágazat elaprózódottságára utal.

A Moran-index értéke - bármely számítási módot tekintjük is - erős pozitív autokorrelációt jelez, tehát várhatóan agglomerálódott az ágazat mind Budapest adataival, mind a nélkül.

Budapest szívóereje, dominanciája rendkívül erős (itt és a környező kistérségekben összesen 31100 fő állt alkalmazásban) (22-23. ábra). Bár elszórtan, elsősorban a nagyobb egyetemi városokban ugyancsak magas LQ értékek jelennek meg. Hot-spotnak nevezhető tehát Budapest, de a cold-spotot is találunk, ilyen szinte az egész Tiszántúl a Debreceni és a környezetében lévő kistérségeket kivéve, ezen a területen tehát igen alacsony az ágazatbeli foglalkoztatottság. Feltehetően ennek (is) köszönhető a szignifikáns (globális) Moran-index érték.

30. táblázat: Az Információtechnológiai szolgáltatás ágazat mutatószám-értékei

\begin{tabular}{|c|c|c|c|c|}
\hline & \multicolumn{2}{|c|}{ Budapesttel } & \multicolumn{2}{|c|}{ Budapest nélkül } \\
\hline Átlagos méret (fö) & \multicolumn{2}{|c|}{4} & \multicolumn{2}{|c|}{2} \\
\hline Vállalkozások száma (db) & \multicolumn{2}{|c|}{15695} & \multicolumn{2}{|c|}{7270} \\
\hline \multirow[t]{2}{*}{ Herfindahl index $\left(\mathrm{H}^{*}\right)$} & \multicolumn{2}{|c|}{0,005} & \multicolumn{2}{|c|}{0,006} \\
\hline & $\begin{array}{c}\text { Szolgáltatásokban } \\
\text { foglal- } \\
\text { koztatottakhoz }\end{array}$ & $\begin{array}{l}\text { Összes foglal- } \\
\text { koztatotthoz }\end{array}$ & $\begin{array}{c}\text { Szolgáltatásokban } \\
\text { foglal- } \\
\text { koztatottakhoz }\end{array}$ & $\begin{array}{l}\text { Összes foglal- } \\
\text { koztatotthoz }\end{array}$ \\
\hline Moran-index & 0,008 & 0,012 & 0,198 & 0,194 \\
\hline p érték & 0,019 & 0,006 & 0,002 & 0,002 \\
\hline EG $\gamma$ mutató & 0,273 & 0,321 & 0,010 & 0,012 \\
\hline
\end{tabular}

Forrás: saját szerkesztés 
22. ábra: Az Információ-technológiai szolgáltatás ágazat LQ és LISA index értékei Budapest adataival

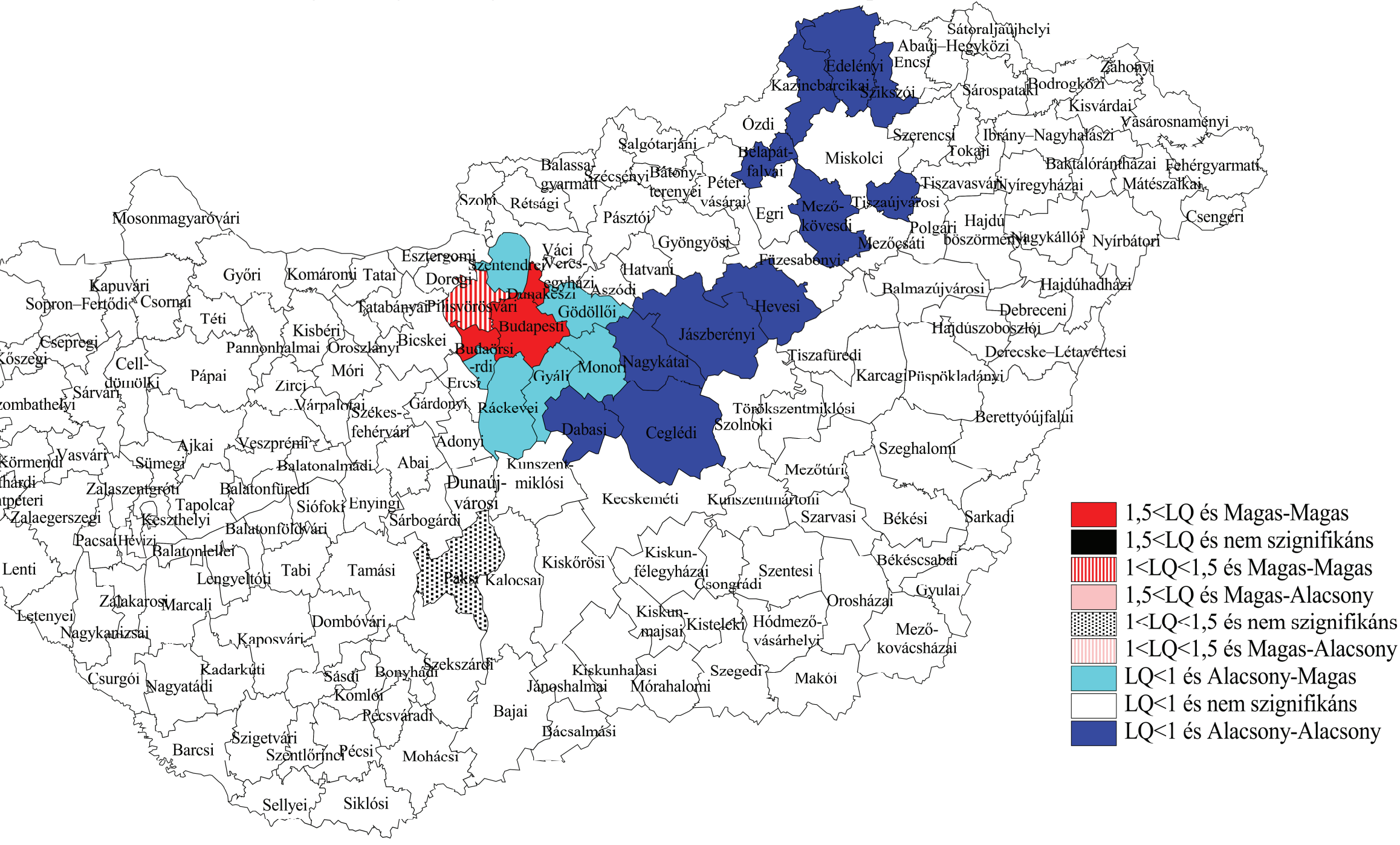

Forrás: saját szerkesztés

Megjegyzés: a szolgáltatásokban foglalkoztatottakhoz viszonyítva. 
23. ábra Az Információ-technológiai szolgáltatáságazat LQ és LISA index értékei Budapest adatai nélkül

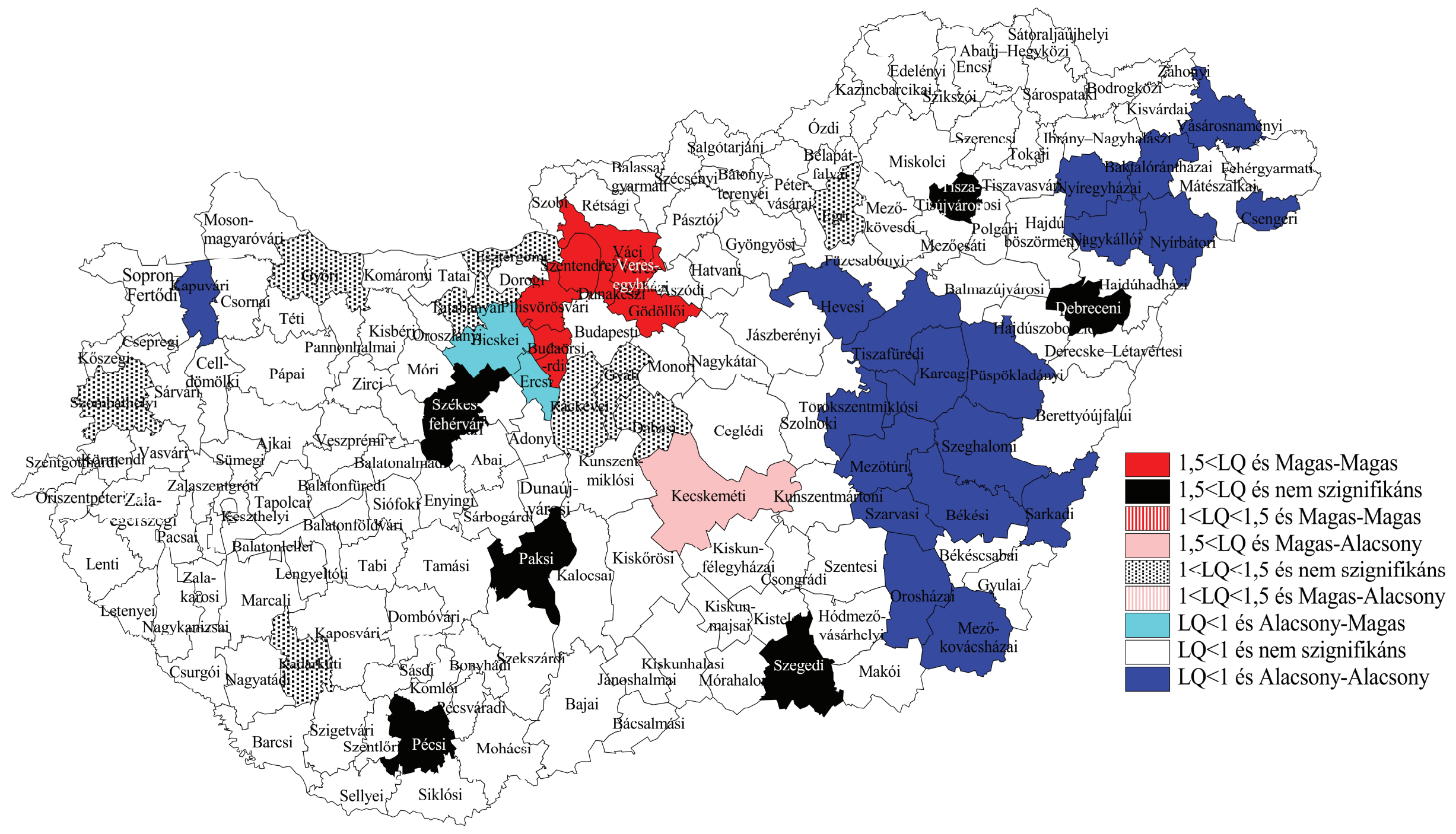

Forrás: saját szerkesztés

Megjegyzés: a szolgáltatásokban foglalkoztatottakhoz viszonyítva. 


\subsubsection{Pénzügyi közvetités, kivéve biztositási, nyugdijpénztári tevékenység}

Ebbe az ágazatba tartozik a pénzforrások gyűjtése és újraelosztása, kivéve azokat, amelyek a biztosítást, a nyugdíjalapokat és a kötelező társadalombiztosítást szolgálják.

Az ágazatban a vizsgálat időpontjában közel 60100 fő dolgozott, közülük 48800 fő Budapesten állt alkalmazásban, tehát az ágazatban foglalkoztatottak 81\%-a a fővárosban bejelentett vállalkozásnál dolgozott. Ezt azért érdemes kihangsúlyozni, mert a 12 legnagyobb, Magyarországon működő bank (ezek legalább 500 főt foglalkoztatnak) - köztük a Magyar Nemzeti Bank, amelynek esetében ténylegesen centralizáltan ellátandó országos feladatról van szó - mind budapesti központtal rendelkeznek, és itt veendő számításba az összes alkalmazottjuk.

31. táblázat: A Pénzügyi közvetítés, kivéve biztosítási, nyugdíjpénztári tevékenység ágazat mutatószám értékei

\begin{tabular}{|c|c|c|c|c|}
\hline & \multicolumn{2}{|c|}{ Budapesttel } & \multicolumn{2}{c|}{ Budapest nélkül } \\
\hline Átlagos méret (fó) & \multicolumn{2}{|c|}{62} & \multicolumn{2}{c|}{24} \\
\hline Vállalkozások száma $(\mathrm{db})$ & \multicolumn{2}{|c|}{1989} & \multicolumn{2}{c|}{051} \\
\hline Herfindahl index $\left(\mathrm{H}^{*}\right)$ & \multicolumn{2}{|c|}{0,042} & 0,006 \\
\hline & $\begin{array}{c}\text { Szolgáltatásokban } \\
\text { foglal- } \\
\text { koztatottakhoz }\end{array}$ & $\begin{array}{c}\text { Összes foglal- } \\
\text { koztatotthoz }\end{array}$ & $\begin{array}{c}\text { Szolgáltatásokban } \\
\text { foglal- } \\
\text { koztatottakhoz }\end{array}$ & $\begin{array}{c}\text { Összes foglal- } \\
\text { koztatotthoz }\end{array}$ \\
\hline Moran-index & $-0,031$ & $-0,025$ & $-0,007$ & $-0,022$ \\
\hline p érték & 0,002 & 0,003 & 0,494 & 0,363 \\
\hline EG $\gamma$ mutató & 0,349 & 0,405 & 0,000 & 0,000 \\
\hline
\end{tabular}

Forrás: saját szerkesztés

Ebben az ágazatban is jelentős tehát a budapesti koncentráció, az EG $\gamma$ mutató értéke is ezt tükrözi: 0,349 (31. táblázat). Ha viszont a főváros adatait kihagyjuk, az ágazat sem térbeli, sem ágazati koncentrációt nem mutat $\left(\mathrm{EG} \gamma=0 ; \mathrm{H}^{*}=0,006\right)$. A Budapesten müködő vállalkozások átlagos mérete jóval nagyobb, mint a vidéki kistérségekben, ahol túlnyomó többségben helyi takarékszövetkezetek müködnek.

A Moran-index alapján Budapest adatainak beszámítása esetén erős negatív autokorreláció tapasztalható, ami annak köszönhető, hogy a fővárost körülvevő kistérségekben viszonylag alacsony az ágazatbeli foglalkoztatottság (24-25. ábra). Ha viszont Budapest adatait nem vizsgáljuk, nincs szignifikáns autokorreláció, a szomszédos kistérségek adatai között semmilyen összefüggésre nem találunk. 
24. ábra: A Pénzügyi közvetítés, kivéve biztosítási, nyugdíjpénztári tevékenység ágazat LQ és LISA index értékei Budapest adataival

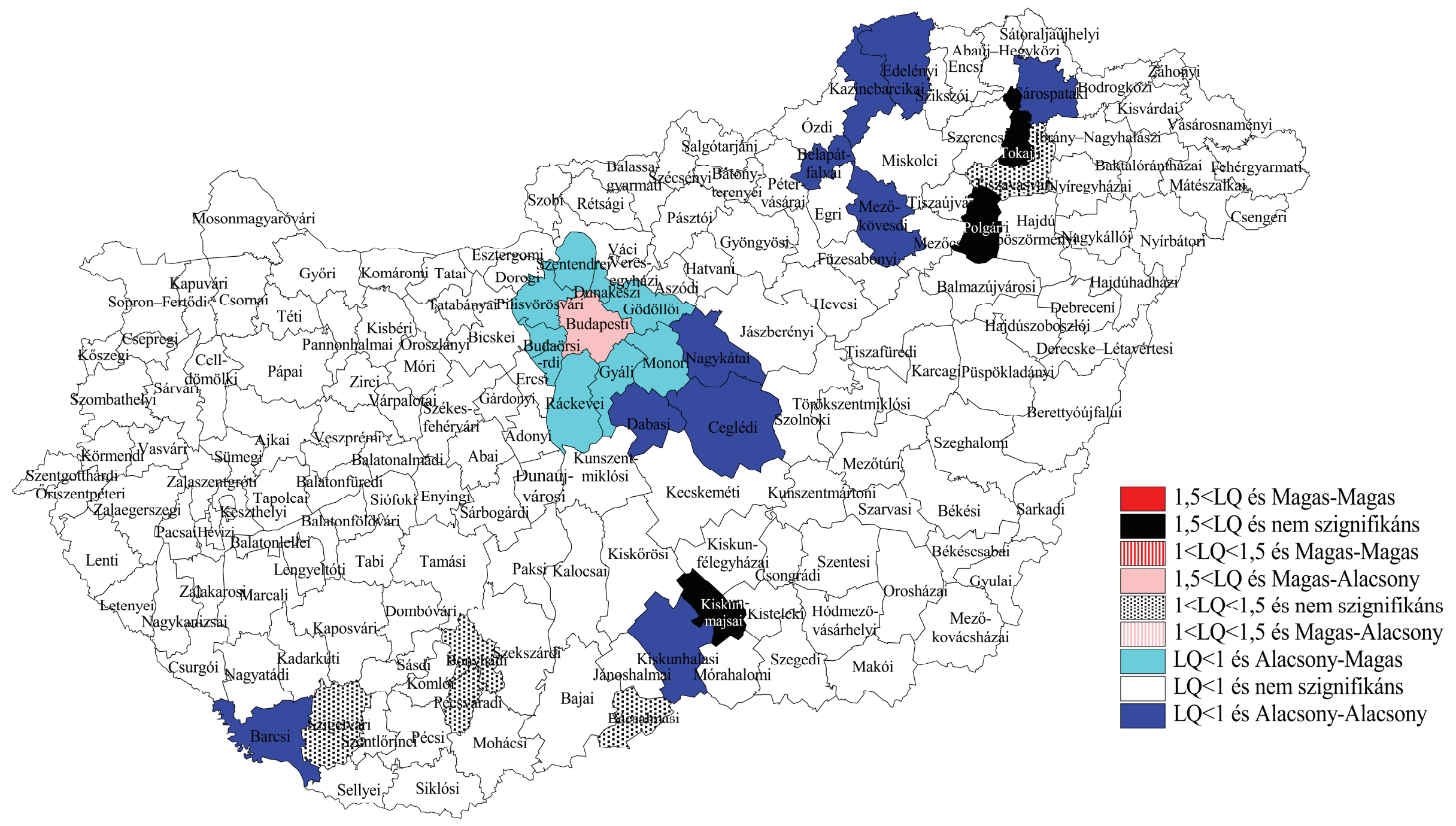

Forrás: saját szerkesztés

Megjegyzés: a szolgáltatásokban foglalkoztatottakhoz viszonyítva. 
25. ábra: A Pénzügyi közvetítés, kivéve biztosítási, nyugdíjpénztári tevékenység ágazat LQ és LISA index értékei Budapest adatai nélkül

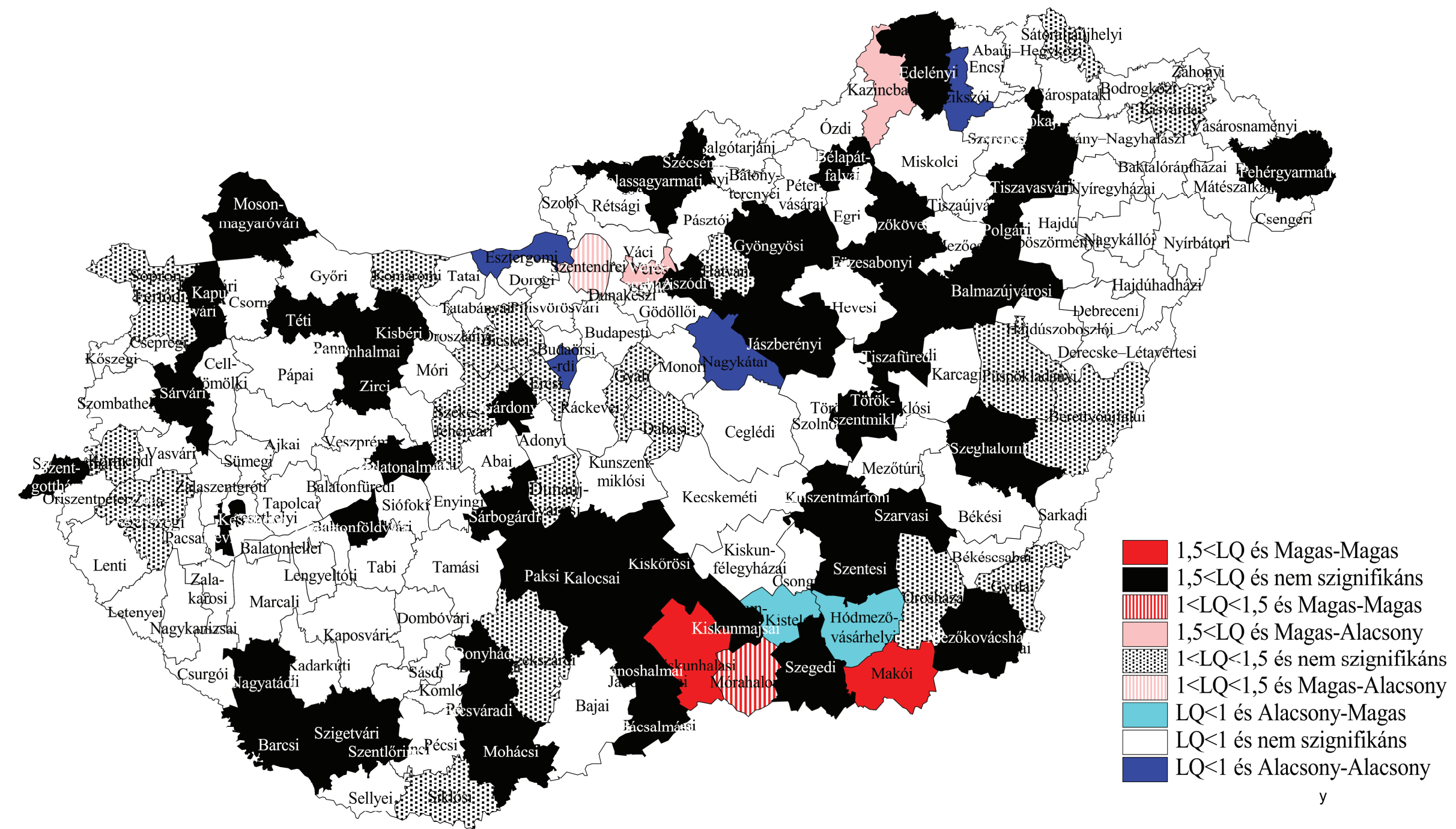

Forrás: saját szerkesztés

Megjegyzés: a szolgáltatásokban foglalkoztatottakhoz viszonyítva. 
A 25. ábra sok kistérségben jelez magas LQ értékeket, amikor Budapest kihagyásával számolunk, azonban ezek a kistérségek az országban teljesen elszórtan helyezkednek el. Ez egybevág azzal, hogy helyi érdekű takarék-szövetkezeteknek a kiszolgálni kívánt ügyfelekhez közel kell települniük, és ebben az esetben a vállalkozások átlagos foglalkoztatottjainak száma is jóval kisebb, mint Budapest adataival együtt számolva. Egyedül a Dél-Alföldi régióban van néhány szomszédos kistérség (a Makói, a Mórahalomi és a Kiskunhalasi), amelyekben magasabb az ágazatbeli foglalkoztatottság, ezek a Budapest adatai nélkül tekintett számítások esetén hot spotnak minősülnek.

\subsubsection{A tudásintenzív ágazatok térbeli eloszlása - összegzés}

Az alfejezet célja a magyar tudásintenzív ágazatok földrajzi eloszlásának kistérségi szintű vizsgálata volt, kitérve a leginnovatívabb ágazatokra. A különböző tudásintenzív ágazatok térbeli eloszlása eredményeim szerint egyáltalán nem egyöntetü.

Egyrészt a tudásintenzív szolgáltatási ágazatok térben rendkívül koncentráltak, bár ezt sok esetben az ágazatok Budapesten meglévő erőteljes sűrüsödése eredményezi. Ez a Budapest központúság jellemző a tudásintenzív feldolgozóipari ágazatokra is, azonban a Gyógyszergyártás ágazat kivételével, amely jelentős mértékben a fővárosban összpontosul, a további ágazatoknál ez kisebb méreteket ölt. A tudásintenzív szolgáltatási ágazatokról Budapest adatai nélkül is elmondható, hogy térben koncentráltabbak, mint a feldolgozóipari ágazatok.

Másrészt a szektorokon belül is jelentős eltéréseket tapasztalhatunk. Ezek az eltérések sok esetben Budapest eltérő erejének köszönhetőek. Azonban a Budapest adatai nélküli vizsgálatok már egyértelmüen az ágazatok különböző strukturális tulajdonságaira, és az ország egyes kistérségeinek különböző fejlettségi színvonalára vezethetők vissza.

Budapest szerepe tehát kétségkívül óriási minden tudásintenzív ágazat esetében. Ezt az is alátámasztja, hogy ezen ágazatok mind nagyobb súllyal vannak jelen a fővárosban, mint azt akár az nemzetgazdaság egészében foglalkoztatottak eloszlása, akár az iparban, építőiparban, illetve a szolgáltatásokban foglalkoztatottak eloszlása alapján várnánk. Azonban - ahogyan azt az egyes külön kiemelt (leginnovatívabb) ágazatok elemzéséből is kiderült - a fóvároson kívül kirajzolódó kép is rendkívül változatos lehet.

A tudásintenzív ágazatok esetében az ágazat innovativitása, illetve az, hogy egy feldolgozóipari ágazat high-tech, vagy medium high-tech ágazatnak minősül-e, nincs kapcsolatban az egyes mutatószámok értékével. Vizsgálatunk alapján ezeket az értékeket más 
gazdasági tényezők befolyásolják, amelyek esetleg a térségi innovációs potenciállal állhatnak kapcsolatban, aminek igazolása egy következő kutatási feladat lehet.

\subsection{Módszertani eredmények és megjegyzések}

A gazdasági tevékenységek két különböző körére (feldolgozóipari alágazatok, illetve tudásintenzív feldolgozóipari és szolgáltatási ágazatok) végeztem el a térbeli koncentráció és agglomeráció globális (EG $\gamma$ és Moran index), valamint lokális (LQ és LISA index) mutatószámainak elemzését. A két vizsgálat eredményei több okból következően nem összehasonlíthatók.

Egyrészt a vizsgálatok különböző térfelosztás mellett (168, illetve 174 kistérség), és különböző ágazatfelosztási szintekre (alágazatok, illetve ágazatok) történtek. Másrészt a két vizsgálat időpontjai között megváltozott a gazdasági tevékenységek egységes ágazati osztályozási rendszere, megtörtént a TEÁOR'03-ról a TEÁOR'08-ra való áttérés, így a második vizsgálat ágazatai nem ugyanazokat az alágazatokat tartalmazzák, amelyeket az első vizsgálat idején.

Az egyetlen kivétel a Gyógyszergyártás, amely mindkét vizsgálatban szerepelt, az elsőben alágazatként, a másodikban ágazatként. E tevékenység esetében esetleg meghatározható volna az időbeli változás (egyik mutatószám esetében nagy eltérés a két időpont között), azonban a térfelosztás megváltozása miatt ez nem célszerü.

Munkám során a jó néhány módszertani eredményt és megjegyzést tudtam összegyüjteni, mert a mutatószámok elemzése során előtérbe került néhány olyan jelenség, amelyről érdemes néhány szót ejteni, hiszen befolyásolhatják az eredmények értelmezését. Ezek a következőkben olvashatók.

\subsubsection{Módszertani eredmények}

1. A gazdasági tevékenységek térbeli eloszlásának két különböző megközelítése - térbeli koncentráció és agglomeráció - mentén létrehozhatók olyan kétdimenziós globális osztályok (húsz osztály), amelyekbe az egyes gazdasági ágazatok besorolhatók, és amelyek alapján meghatározható a vállalkozásokat egymás közelébe vonzó és egymástól eltávolító erők eredőjének sugara. Ilyen táblázatokat hoztam létre mind a feldolgozóipari alágazatok (15-16. táblázat - 106. o.), mind pedig a tudásintenzív ágazatok vizsgálata során (22-23. táblázat - 119. o.). 
2. A gazdasági tevékenységek térbeli eloszlásának két különböző aspektusa, tehát a térbeli koncentráció és agglomeráció mentén létrehozhatók olyan - két mutatószám eltérő értékei alapján definiálható - lokális osztályok (9 osztály), amelyekbe az egyes területi egységek besorolhatók. Ezek alapján meghatározható a vállalkozásokat egymás közelébe vonzó és egymástól eltávolító erők eredőjének lokális sugara (20. táblázat - 115. o.). Ezen osztályozás alapján készültek a tudásintenzív ágazatokra vonatkozó térképek (18-25. ábra és a Melléklet II/2 - II/27 táblái), amelyekről így egyszerre leolvashatók a lokális mutatók értékei. Érdemes megjegyezni, hogy az LQ értékek alapján 3, a LISA értékek alapján 5 osztályba sorolhatók a kistérségek, ami osztályt eredményezne, de ezek közül 6 nem releváns, hiszen például az $L Q$ > 1 és Alacsony-Magas párosítás nem jöhet létre, mert az LQ alapján ， a LISA alapján volna.

3. Magyarországon a kistérségi térfelosztási szint megfelelőnek tünik az egyes gazdasági ágazatok térbeli eloszlásának vizsgálatára és összehasonlítására olyan értelemben, hogy az egyes mutatószámok értékei széles spektrumban szóródnak, így jól elkülöníthetők az eltérő jellegü gazdasági tevékenységek. Habár a kutatást csak kistérségekre vonatkozóan végeztem, ezért eredményeim csak olyan erők meglétét és hatósugarát tudják kimutatni, amelyek ezen a térfelosztási szinten jelennek meg. A vizsgálatot hasznos lenne megyei, esetleg települési szinten is elvégezni.

\subsubsection{Módszertani megjegyzések}

1. Abszolút vagy fajlagos eltérés. Az LQ értékek az - hányadost jelentik, miközben mind a lokális és globális Moran-index, mind az Ellison-Glaeser $\gamma$ mutató az értékek alapján számolandó. Az előbbi a koncentrációt a kistérség saját foglalkoztatási szintjéhez méri, tehát fajlagos eltérést mér, utóbbi viszont az országos foglalkoztatottság abszolút (oda- vagy el-)áramlását méri. Ezért érdemes mindkettőt alkalmazni a vizsgálat során, és az eredményeket ennek megfelelően kell interpretálni.

2. A mutatószámok torzulása. Mivel nem álltak rendelkezésemre pontos foglalkoztatottsági adatok, csak a vállalatok létszám-kategóriába való tartozása, ezért ezeket becsülnöm kellett. Ez akár jelentős mértékben is torzíthatja a mutatószámok értékét, elegendő meggondolnunk, hogy ha több vállalkozásnak a létszámkategóriáján belül magas alkalmazotti létszáma van, akkor a becslés a Herfindahl- 
index értékét a valódihoz képest jelentősen, akár a felére is csökkentheti, ami így az EG $\gamma$ értékét számottevően növeli.

3. Agglomeráció - az-e? A Moran-index magas értéke mögött nem biztos, hogy valódi agglomerálódás áll. Ez olyan esetekben fordulhat elő, amikor nincs kimutatható térbeli koncentrálódás, de pozitív térbeli autokorrelációt tapasztalunk. Ennek lehetséges oka az, hogy sok az olyan kistérség, amelyekben alacsony az (al-) ágazatbeli foglalkoztatottság, netán ,üresek”, így emelkedett a Moran index érték. E probléma kiküszöbölése érdekében a globális mutató alkalmazása után érdemes további - lokális - mutatószámokat is használni. Abban az esetben viszont, amikor az adott ágazat térben koncentrált, de valójában nem agglomerált, az alkalmazott mutatószámunk, a Moran index, rendszerint nem mutat hamis agglomerálódást, köszönhetően a számítás módjának, amely a $d_{i}=s_{i}-x_{i}$ abszolút mutatószámértékek alapján történik - szemben az Arbia és társai (2006) által alkalmazott $L Q_{i}=\frac{s_{i}}{x_{i}}$ értékekkel.

4. Országhatár és szomszédok száma. Ha egy kistérség a magas lokális Moran-index értéke alapján a hot spot, azaz a Magas-Magas kategóriába tartozik, akkor az alapvetően azt jelenti, hogy a kistérségben és az öt körülvevő szomszédjaiban is átlagosan sűrübb a vizsgált tevékenység. Ez az országhatáron megtévesztő lehet, hiszen nem tudjuk számításba venni a kistérség határon túli szomszédjait, így alacsony a szomszédok száma, ami torzítja az eredményeket. A határmentihatárközeli területi egységek nem csak a területi autokorreláció, hanem más térökonometriai módszerek esetében is gondot okozhatnak (Dusek 2001).

5. A térbeli sürüsödés okai. Amennyiben egy iparág esetében a vizsgálat magas mutatószámértékeket eredményez, az valamilyen, a térbeli sürüsödés irányába ható okot jelez, azaz annak meglétét igazolja. Mivel azonban ez a sürüsödést előidéző tényező lehet gazdasági, társadalmi, földrajzi vagy egyéb más ok is, minden esetben egyedileg kell utánajárni, ami a mutatószámok további, differenciáltabb alkalmazását, esetleg más módszerek bevonását jelenti. 


\section{5. Összegzés}

Disszertációmban áttekintettem a gazdasági tevékenységek térbeli eloszlásához kapcsolódó fogalmakat, az egyenlőtlen eloszlás új-gazdaságföldrajzi magyarázatait. Ezt követően a koncentráció-agglomeráció fogalompár megkülönböztetését szolgáló koncepciókat mutattam be, és a Lafourcade és Mion (2007) fogalomrendszer szerint osztályozva vezettem fel azokat a mutatószámokat, amelyek az egyenlőtlen térbeli eloszlást hivatottak mérni. A nemzetközi szakirodalom bemutatása után alkalmaztam ezek közül az EG $\gamma$ mutatót és a Moran indexet, mint globális, az LQ és LISA indexet pedig, mint lokális mutatókat a magyar feldolgozóipari alágazatok egy körére, valamint tudásintenzív feldolgozóipari és szolgáltatási ágazatokra kistérségi térfelosztási szint mellett. Ezek után pedig mind módszertani, mind gazdasági következtetések levonására vállalkoztam.

Eredményeim a négy hipotézis tesztelése alapján a következő tézisekben foglalhatók össze:

I. hipotézis: A magyar gazdasági tevékenységek esetében kistérségi szinten jelentös eltérés várható a Budapest adatainak figyelembevételével, illetve az ezen adatok nélkül kiszámított értékekben

a. a térbeli koncentráció méröszámában,

b. az agglomeráció méröszámában.

Mind a feldolgozóipari alágazatokra, mind pedig a tudásintenzív ágazatokra vonatkozó vizsgálatok esetében gyakran jelentős eltérések tapasztalhatók a mutatók értékeiben a Budapest adataival és az azok nélküli számítások esetén. A mutatószámokban történő változás iránya nem egyértelmü, azonban a szóródás csökkenése egyértelmű, az ágazatok közötti különbségek nagyobb részt Budapestnek köszönhetők. A korrelációs vizsgálat során térbeli koncentráció mutatószámában (EG $\gamma$ ) szignifikáns eltérés volt tapasztalható a Budapest adataival és az azok nélkül kiszámított mutatóértékekben, azonban az agglomeráció mutatószámában (Moran index) értékek esetében sem a korrelációs vizsgálat, sem a t-próba nem mutatott ki különbséget 5\%-os szignifikancia szinten. Ebből következően:

1. tézis: A magyar feldolgozóipari alágazatokra kistérségi szinten jelentös eltérés várható a térbeli koncentráció mutatószámában a Budapest adatainak figyelembevételével, illetve az ezen adatok nélkül kiszámított értékekben, az agglomeráció méröszámában viszont ez az eltérés nem jelentös. 
II. hipotézis: Az, hogy a mutatószámok viszonyítási alapját képező foglalkoztatottsági adatok az egész nemzetgazdaságra, vagy csak az ipar és építöipar szektorára vonatkoznak, szignifikáns különbséget jelent Magyarországon, kistérségi szinten:

a. a térbeli koncentráció méröszámában;

b. az agglomeráció méröszámában.

A vizsgálat nem mutatott ki 5\%-os szignifikancia szinten eltérést a két különböző számítási mód esetében az EG $\gamma$ értékei között, azonban vannak olyan ágazatok, amelyekre jelentős a különbség. Az agglomeráció mérőszámában (Moran index) Budapest adataival együtt történt számítások esetében 2,14\% szignifikancia szinten eltérés van az ipari és építöipari foglalkoztatottakhoz, illetve a nemzetgazdaság egészében foglalkoztatottakhoz mért mutatóértékek között. Ebből következően:

2. tézis: A magyar feldolgozóipari alágazatok esetében kistérségi szinten az, hogy a mutatószámok alapját képezö foglalkoztatottsági adatok az egész nemzetgazdaságra vonatkoznak, vagy pedig a nemzetgazdaságnak csak az ipar és építőipar szektorára, nem okoz releváns különbséget sem a térbeli koncentráció, sem pedig az agglomeráció méröszámában.

III. hipotézis: Magyarországon, kistérségi szinten a tudásintenzív ágazatok esetében várhatóan magasabb mutató értékeket kapunk

a. a térbeli koncentráció

b. az agglomeráció

méröszámai esetén, mint a nem tudásintenzív ágazatokéban.

A vizsgálat a tudásintenzív feldolgozóipari alágazatokra 9\%-os szignifikancia szinten magasabb térbeli koncentrációt jelzett, mint a nem tudásintenzív alágazatokra. Ebből következően:

3. tézis: A magyar feldolgozóipari alágazatok esetében kistérségi szinten magasabb térbeli koncentráció várható a tudásintenzitás növekedésével, az agglomerálódás mutatószámában az eltérés ezzel szemben nem szignifikáns.

IV. hipotézis: Magyarországon kistérségi szinten a térbeli koncentráció és agglomeráció közötti - Lafourcade és Mion által megfogalmazott - különbségtétel módszertanilag megalapozott, a kétféle fogalom méröszámai alapján létrehozott két dimenzió független. 
A 2. fejezetben bemutatott mutatószámok két jól elkülöníthető csoportba oszthatók, azokéra, amelyek a gazdasági tevékenységek térbeli sürüsödését mérik, miközben az egyes területi egységek térkapcsolatai irrelevánsak és azokéra, amelyek kifejezetten e térkapcsolatok alapján igyekeznek struktúrát találni a gazdasági tevékenységek eloszlásában. A korrelációs vizsgálatok arra engednek következtetni, hogy nincs együttmozgás kapcsolat az EG $\gamma$ mutató és Moran index értékek között, vagyis egyiknek az értékéből sem lehet következtetni a másikéra. Ebből következően:

4. tézis: Magyarországon a feldolgozóipari alágazatok esetében kistérségi szinten a térbeli koncentráció és agglomeráció közötti - Lafourcade és Mion által megfogalmazott - különbségtétel módszertanilag megalapozott, a kétféle fogalom méröszámai alapján létrehozott két dimenzió független.

Dolgozatomban véleményem szerint újdonságértékủ a gazdasági tevékenységek térbeli eloszlásának nemzetközi empirikus vizsgálatait bemutató fejezet. Ugyancsak újszerü a magyar gazdasági tevékenységek fontos szeleteinek kistérségi szintủ vizsgálata párhuzamosan a térbeli koncentrálódásra és agglomerálódásra, az előzőekben felvezetett tézisek, és a negyedik fejezetben bemutatott módszertani eredmények. Ez utóbbiak közül elsősorban a gazdasági tevékenységek térbeli eloszlásának két aspektusa alapján létrehozható globális osztályozás az ágazatokra és lokális osztályozási rendszer a kistérségekre emelhető ki. 


\section{IRODALOMJEGYZÉK}

ÁCs, Z. - AUdRETSCH, D. - FELDMAN, M. P. (1994): R\&D spillovers and recipient firm size. The Review of Economics and Statistic, 76. 336-340. o.

ÁCS, Z. (2009): Jaffe-Feldman-Varga: the search for knowledge spillovers. In Varga A. (eds) Universities, Knowledge Transfer and Regional Development. Geography, Entrepreneurship and Policy. Edward Elgar, Cheltenham, UK and Northampton, MA, USA, 36-56. o.

AleCKE, B. - UnTIEDT, G. (2008): Die räumliche Konzentration von Industrie und Dienstleistungen in Deutschland. Neue empirische Evidenz mit dem Ellison-Glaeser-Index. Jahrbuch für Regionalwissenschaft. 28. évf. 61-92. o.

Alecke, B. -Alsleben, C. -Scharr, F. - G. Untiedt, G. (2006): Are there really high-tech clusters? The geographic concentration of German manufacturing industries and its determinants. The Annals of Regional Science, vol. 40. évf., 19-42 o.

Alonso-Villar, O. - CHAMORRo-Rivas, J. M. - GonZAlEZ-CerdeirA, X. (2004): Agglomeration economies in manufacturing industries: the case of Spain. Applied Economics, 36. évf. 21032116. o.

AlsLEBEN, C. (2005): The Downside of Knowledge Spillovers: An Explanation for the Dispersion of High-tech Industries. Journal of Economics, 84. évf., 5. sz. 217-248. o.

AnSELIN, L. (1988): Spatial Econometrics: Methods and Models. Kluwer Academic. Dordrecht.

AnSELIn, L. (1995). Local Indicators of Spatial Association - LISA. Geographical Analysis, 27. évf. 2. sz. 93-115. o.

ANSELIN, L. - VARGA A. - ÁCS, Z. (1997): Local geographic spillovers between university research and high technology innovations. Journal of Urban Economics, 42. sz. 422-448. o.

ARBIA, G. (2001): The role of spatial effects in the empirical analysis of regional concentration. Journal of Geographical Systems, 3. sz. 271-281. o.

Arbia, G. - De Dominicis, L. - DE Groot, H. L. F. (2006): Spatial Distribution of Economic Activities in Local Labour Market Areas: the Case of Italy. ERSA conference papers ersa06p497, European Regional Science Association.

ARROW, K. J. (1962): Economic welfare and the allocation of resources for invention. In: The Rate and Direction of Inventive Activity: Economic and Social Factors. National Bureau of Economic Research, pages 609-626. o.

AUdRETSCH, D.B. - FELDMAN M.P. (1996): R\&D Spillovers and the Geography of Innovation and Production. American Economic Review, 86. köt. 630-640. o.

BAJMÓCY Z. (2012): Innovációs index kistérségi szinten - Csak játék a számokkal? In Bajmócy Z. Lengyel I. - Málovics Gy. (szerk.): Regionális innovációs képesség, versenyképesség és fenntarthatóság. JATEPress, Szeged, 13-32.o. 
BAJMÓCY Z. - SZAKÁLNÉ KANÓ I. (2009a): Hazai kistérségek innovációs képességének elemzése. Tér és Társadalom, XXIII. évf. 2. sz. 45-68. o.

BAJMÓCY Z. - SZAKÁLNÉ KANÓ I. (2009b): Measuring the Innovation Performance of Hungarian Subregions. In Bajmócy Z.- Lengyel I. (eds): Regional Competitiveness, Innovation and Environment. JATEPress, Szeged, 99-121.o.

BAJMÓCY Z. - SZAKÁLNÉ KANÓ I. (2010): Innovációs képesség elemzése kistérségi szinten. A Délalföldi és Észak-magyarországi régiók összevetése. Észak-magyarországi Stratégiai Füzetek, 7. évf. 1. sz. 36-46. o.

Baldwin, R. E. - Forslid, R. - MARTin, P. - OtTAViano, G. I. P. - Robert-Nicoud, F. (2003): Economic Geography and Public Policy. Princeton University Press, Princeton

Barrios, S - Bertinelli, L - Strobl, E - TeiXeira, A.C. (2003): Agglomeration Economies and the Location of Industries: A Comparison of Three Small European Countries. CORE Discussion paper 67.

BArrios, S - Bertinelli, L - STROBl, E - TeiXeira, A.C. (2005): The dynamics of agglomeration: evidence from Ireland and Portugal. Journal of Urban Economics, 57. évf. 1. sz. 170-188. o.

Barrios, S. - Bertinelli L. - Strobl E. - Teixeira A.C. (2009): Spatial Distribution of Manufacturing Activity and its Determinants: A Comparison of Three Small European Countries. Regional Studies, 43. évf. 5. sz. 721-738. o.

Bertinelli, L. - DeCROP, A. (2005): Geographical Agglomeration: Ellison and Glaeser's Index Applied to the Case of Belgian Manufacturing Industry. Regional Studies, 39. évf. 5. sz. 567583. o.

BonacCorsi, A. - PIScitello, L. - Rossi, C.(2006): Explaining The Territorial Adoption Of New Technologies - A Spatial Econometric Approach. ERSA conference papers ersa05p92, European Regional Science Association.

BonacCorsi, A. - Piscitello, L. - Rossi, C. (2006): Knowledge, Spillovers and Firm's International Growth. An Analysis at the Italian NUTS 3 Level. ERSA conference papers ersa06p116, European Regional Science Association.

Brakman, S. - Garretsen, H. - VAn MarrewiJk, C. (2009): The New Introduction to Geographical Economics. Cambridge University Press, Cambridge (MA).

Braunerhjelm, P. - Borgman, B. (2004): Geographical Concentration, Entrepreneurship and Regional Growth: Evidence from Regional data in Sweden 1975-99. Regional Studies, 38. évf. 8. sz. 929-947. o.

BraunerhJelm, P. - Johansson, D. (2003): The determinants of spatial concentration: the manufacturing and service sectors in an international perspective. Industry and Innovation, 10. sz. 41-63. o.

BRESCHI, S. (1998): Agglomeration economies, knowledge spillovers, technological diversity, and spatial clustering of innovations. Liuc Papers, Serie Economia e Impresa, 57. sz. 
BRÜLHART, M. (1998): Economic geography, industry, location and trade: the evidence. World Economy, 21. sz. 775-801. o.

CARroll, M.C. - REID, N. - SMITH, B.W. (2008): Location quotients versus spatial au-tocorrelation in identifying potential cluster regions. Annals of Regional Science, 42. évf. 2. sz. 449-463. o.

Ciccone, A. - Hall, R. E. (1996): Productivity and the Density of Economic Activities. American Economic Review, 86. évf. 1. sz. 54-70. o.

ClifF, A. D. - ORD, J. K. (1973): Spatial Autocorrelation. Pion, London.

COMBES, P.P. -MAYER, T.- J.F. THISSE (2008): Economic Geography. The Integration of Regions and Nations. Princeton University Press, Princeton and Oxford.

COMBES, P.P. - DURANTON, G. (2006): Labour pooling, labour poaching, and spatial clustering. Regional Science and Urban Economics. 36. évf. 1-28. o.

CReSSIE, N. A. (1993): Statistics for Spatial Data. New York, John Wiley \& Sons.

DeVEREuX, M.P. - Griffith, R. - SimPSON, H. (1999): The Geographic Distribution of Production Activity in the UK. IFS Working Papers W99/26. Institute for Fiscal Studies.

Dumais, G. - Ellison, G. - GlAESER, E. (1997): Geographic concentration as a dynamic process. NBER Working Paper 6270.

DUSEK T. (2001): A területi mozgóátlag. Területi Statisztika, 3. sz. 215-229. o.

DUSEK T. (2004): A területi elemzések alapjai. ELTE Regionális Földrajzi Tanszék - MTA-ELTE Regionális Tudományi Kutatócsoport, Budapest.

DusEK T. (2006): Területi statisztika, valószínűségszámítás és statisztikai következtetéselmélet. Terïleti Statisztika, 3. sz. 223-239.o.

DuRANTON, G. - Overman, H.G. (2005): Testing for localization using micro-geographic data. CEPR Discussion Papers 3379

EC (2010): Európa 2020, Az intelligens, fenntartható és inkluzív növekedés stratégiája. COM (2010) 2020, Brüsszel.

Ellison, G. - GlAeSER, E. (1994): Geographic Concentration in U.S. Manufacturing Industries: A Dartboard Approach, NBER Working Papers 4840

Ellison, G. - GlaESER, E. (1997): Geographic Concentration in U.S. Manufacturing Industries: A Dartboard Approach. Journal of Political Economy, 105. évf. 5. sz. 889-927. o.

ENYEDI GY. (2012): Városi világ. Akadémiai Kiadó, Budapest

EUROSTAT (2009): High-tech industry and knowledge-intensive services. Metadata. Letölthető: http://epp.eurostat.ec.europa.eu/cache/ITY_SDDS/EN/htec_esms.htm

EUROSTAT (2011): European cities - demographic challenges. Letölthetö: http://epp.eurostat.ec.europa.eu/statistics_explained/index.php/European_cities__demographic_challenges

EUROSTAT (2012): Urban Audit. Letölthető: http://epp.eurostat.ec.europa.eu/portal/page/portal /region_cities/city_urban/data_cities/database_sub1 
FELDMAn, M.P. (1994): The Geography of Innovation. The Kluwer Academic Puplishers, New York.

FELDMAN, M.P. (2000): Location and innovation: the new economic geography of innovation, spillovers, and agglomeration. In Clark, G. L. - Feldman, M. P. - Gertler M. S (eds): The Oxford handbook of economic geography. Oxford University Press, New York, 373-388. o.

FRANK, B. (2008): Location decisions in a changing labour market environment, The case of filmrelated services. Jahrbuch für Regionalwissenschaft, 28. évf. 1. sz. 31-42. o.

Fujita, M. - Krugman, P. - Venables, A. J. (1999): The Spatial Economy. The MiT Press, Cambridge

FujitA, M. - ThISSE, J.F. (2002): Economics of Agglomeration: Cities, Industrial Location and Regional Growth. Cambridge University Press, Cambridge

GEARY, R. C. (1954): The Contiguity Ratio and Statistical Mapping. The Incorporated Statistician, 5. évf. 3. sz. 115-145. o.

GeCSE G. - NiKodÉMUS A. (2003): A hazai klaszterek lehatárolásának problémái — lokációs hányados. Területi Statisztika, 6. sz. 507-522. o.

Getis, A. - Aldstadt, J. (2004): Constructing the Spatial Weight Matrix Using a Local Statistic. Geographical Analysis, 36. évf. 2. sz. 90-104. o.

Getis, A. - ORD, J. K. (1992): The Analysis of Spatial Association by use of Distance Statistics. Geographical Analysis, 24. évf. 189-206. o.

Getis, A. - ORD, J.K., (1996): Local Spatial Statistics: An Overview. In Longley, P. - Batty, M. (eds): Spatial Analysis: Modeling in a GIS Environment. Geoinformation International, Cambridge (UK), 261-277. o.

GRILICHES, ZVI. (1979): Issues in assessing the contributions of research and development to productivity growth. The Bell Journal of Economics, 10 évf., 92-116. o.

GRILICHES, ZVI. (1992): The Search for R\&D Spillovers. Scandinavian Journal of Economics, 94 évf., 29-47. o.

Guillain, R. - Le Gallo, J. (2007): Agglomeration and dispersion of economic activities in Paris and its surroundings: An exploratory spatial data analysis. LEG - Document de travail Economie 2007-01, Université de Bourgogne.

Guimaraes , P. - Figueiredo, O. - Woodward, D. (2009): Dartboard tests for the location quotient. Regional Science and Urban Economics, 39. évf. 360-364. o.

HENDERSON, J. V. - THISSE J. F. (eds) (2004): The Handbook of Regional and Urban Economics, Vol. IV, Cities and Geography, Amsterdam, North-Holland.

HERFINDAHL, O.C. (1950): Concentration in the Steel Industry. PhD dissertation, Columbia University.

HiRSCHMAN, A. (1958), Strategy of Economic Development. New Haven, CT: Yale University Press. 
Holmes, T. J. - SteVens, J. J. (2002): Geographic concentration and establishment size: analysis in an alternative economic geography model. Finance and Economics Discussion Series, 17. sz., Board of Governors of the Federal Reserve System (U.S.)

HunYAdi L. - MundRUCZÓ GY. - ViTA L. (1996): Statisztika. Aula, Budapest.

JACOBS, J. (1969): The Economy of Cities. Random House. New York.

JAFFE, A. B.(1986): Technological Opportunity and Spillovers of R\&D: Evidence from Firms' Patents, Profits, and Market Value. American Economic Review, American Economic Association, 76. évf. 5. sz. 984-1001.o.

JAFFe, A. - Trajtenberg, M., - Henderson, R. (1993): Geographic localization of knowledge spillovers as evidenced by patent citations. Quarterly Journal of Economics, 108. sz. 577598.0.

KERÉKGYÁRTÓ GY.-NÉ (1980): A koncentráció vizsgálatának néhány módszertani kérdése. Egyetemi Szemle, II. évf. 3. sz. 77-85. o.

Koós B. (2007): A szuburbanizációs folyamat a magyar gazdaságban. Közgazdasági Szemle, LIV. évf. 4. sz. 334-349. o.

KRUGMAn, P. (1991a): Increasing returns and economic geography. Journal of Political Economy, 99. sz. 483-99. o.

Krugman, P. (1991b): Geography and Trade. MIT Press, Cambridge (MA)

Krugman, P. (1995): Technology, Trade, and Factor Prices. NBER Working Papers 5355

Krugman, P. (2000): A földrajz szerepe a fejlődésben. Tér és Társadalom, 14. évf. 4. sz. 1-21. o.

KrugMAn, P. (2003): Földrajz és kereskedelem. Nemzeti Tankönyvkiadó, Budapest.

KSH (Központi Statisztikai Hivatal) (2003): A gazdasági tevékenységek egységes ágazati osztályozási rendszere és a tevékenységek tartalmi meghatározása (TEÁOR'03). Budapest.

KSH (Központi Statisztikai Hivatal) (2007): CÉG-KÓD-TÁR - A KSH céginformációs adattára, II. negyedév. Budapest.

KSH (Központi Statisztikai Hivatal) (2008): A gazdasági tevékenységek egységes ágazati osztályozási rendszere és a tevékenységek tartalmi meghatározása (TEÁOR'08). Budapest.

KSH (Központi Statisztikai Hivatal) (2008): Területi Statisztikai Évkönyv 2007. Budapest.

KSH (Központi Statisztikai Hivatal) (2009): CÉG-KÓD-TÁR, A KSH céginformációs adattára, 2009 II. negyedév. Budapest.

KSH (Központi Statisztikai Hivatal) (2009): CÉG-KÓD-TÁR, A KSH céginformációs adattára, 2009 III. negyedév. Budapest.

KSH (Központi Statisztikai Hivatal) (2010): Magyar Statisztikai évkönyv 2009. Budapest.

Lafourcade, M. - Mion, G. (2007): Concentration, Agglomeration and the Size of Plants. Regional Science and Urban Economics, 37. évf. 1. sz. 46-68. o.

LENGYEL B. - LEYDESDORFF, L. (2008): A magyar gazdaság tudásalapú szerveződésének mérése: az innovációs rendszerek szinergiáinak térbelisége. Közgazdasági Szemle, 55, 522-547. o. 
LENGYEL I. (2010a): Regionális gazdaságfejlesztés. Versenyképesség, klaszterek és alulról szerveződő stratégiák. Akadémiai Kiadó, Budapest.

LENGYEL, I. (2010b): A regionális tudomány "térnyerése": reális esélyek avagy csalfa délibábok? Tér és Társadalom, 24. évf. 3. sz. 11-40. o.

LENGYEL I. - MOZSÁR F. (2002): A külső gazdasági hatások (externáliák) térbelisége. Tér és társadalom, 16. évf. 2. sz. 1-20. o.

LENGYel I. - RECHNitZer J. (2004): Regionális gazdaságtan. Dialóg Campus, Budapest-Pécs.

LuKOVICs M. (2008):Térségek versenyképességének mérése. JATEPress, Szeged

Marshall, A. (1920): Principles of Economics: An Introductory Volume. Macmillan. London.

MAYerhofer, P. - PALME, G. (2001): Sachgüterproduktion und Dienstleistungen: Sektorale

Wettbewerbsfähigkeit und regionale Integrationsfolgen. In Mayerhofer, P. - Palme, G. (Red.):

PREPARITY - Strukturpolitik und Raumplanung in den Regionen an der mitteleuropäischen EU-Außengrenze zur Vorbereitung auf die EU-Osterweiterung. WIFO, Wien.

Maurel, F. - Sedillot, B. (1999): A Measure of the Geographic Concentration in French Manufacturing Industries. Regional Science and Urban Economics, 29. évf. 5. sz. 575-604. o.

MiLleR ET AL.(2001): Business Clusters in the UK - a first assessment. DTI, London.

Moineddin, R. - Beyene, J. - Boyle, E. (2003): On the Location Quotient Confidence Interval. Geographical Analysis, 35. sz. 249-256. O.

Moran, P. A. P. (1950): Notes on Continuous Stochastic Phenomena. Biometrika, 37. évf. 1. sz. 1723. 0 .

Moreno, R. - PACI, R. - USAI, S. (2005): Innovation Clusters in the European Regions. Working Paper CRENoS 2005/12, Centre for North South Economic Research, University of Cagliari and Sassari, Sardinia.

MOzSÁR F. (2000): Az externáliák szerepe a regionális gazdasági teljesítmény magyarázatában és növelésében. In Farkas B.—Lengyel I. (szerk.) Versenyképesség — regionális versenyképesség. SZTE Gazdaságtudományi Kar Közleményei, JATEPress, Szeged, 100-114. o.

MukKalA, K (2004): Agglomeration economies in the Finnish manufacturing sector. Applied Economics, 21. sz., 2419-2427. o.

NAKAMURA, R - MorRison PAUl, C. (2009): Measuring Agglomeration. In Capello, R. - Nijkamp, P. (eds) Handbook of Regional Growth and Development Theories. Edward Elgar Cheltenham, UK, Northampton, MA, USA, 305-328. o.

NeMES NAGY J. (2005) (szerk.): Regionális elemzési módszerek. Regionális Tudományi Tanulmányok, 11. ELTE Regionális Földrajzi Tanszék - MTA-ELTE Regionális Tudományi Kutatócsoport, Budapest

OAXACA, R. (1973): Male-Female Wage Differentials in Urban Labor Markets. Working Papers 396, Princeton University, Department of Economics, Industrial Relations Section. 
OECD (2001): Science, Technology and Industry Scoreboard: Towards a Knowledge-based Economy.

Organization For Economic Cooperation and Development, Paris.

O’Donoghue, D. - Gleave, B. (2004): A Note on Metthods for Measuring Industrial Agglomeration. Regional Studies, 38. évf. 4. sz. 419-427. o.

PARR, J.B. (2002): Missing Elements in the Analysis of Agglomeration Economics. International Regional Science Review, 2. 151-168. o.

PATIK R. (2005): A regionális klaszterek feltérképezéséről. Területi Statisztika, 45. évf. 6. sz. 519541. o.

PATIK R. - DEÁK SZ. (2005): A regionális klaszterek feltérképezése a gyakorlatban. Tér és Társadalom, 19. évf. 3-4. sz. 139-170. o.

PEARCE, D.W. (1993): A modern közgazdaságtan ismerettára. Közgazdasági és Jogi Könyvkiadó, Budapest.

PING, J. L. - GREEN, C.J - ZARTMAN, R.E. - BRONSON, K.F. (2004): Exploring Spatial Dependence of Cotton Yield Using Global and Local Autocorrelation Statistics. Field Crop Research, 89. évf. 2-3. sz. 219-236. o.

Ratanawaraha, A. - POlensKe, K.R. (2007): Measuring the geography of innovation: a literature review. In Polenske, K.R. (ed.): The economic Geography of Innovation. Cambridge University Press, New York, 30-59. o.

PORTER, M. (1990): The Competitive Advantage of Nations. The Free Press, New York.

ROMER, P.M. (1986): Increasing returns and long run growth. Journal of Political Economy, 94 évf. 1002-1037.o.

Rosenthal, S.S. - STRANGE W.C. (2001): "The Determinants of Agglomeration, Journal of Urban Economics, 50. sz., 191-229. o.

Scitovsky, T. (1954): Two concepts of external economies. Journal of Political Economy, 62. sz, $143-151.0$.

SoHN, J. (2004): Do birds of a feather flock together?: Economic linkage and geographic proximity. The Annals of Regional Science, 38. évf. 1. sz. 47-73 o.

SZAKÁlNÉ KANÓ I. (2005a): Models in the New Economic Geography. In Lehoczky L. - Kalmár L. (eds): 5th International Conference of PhD Students: Economics I. University of Miskolc, Innovation and Technology Transfer Centre, Miskolc, 253-260. o.

SZAKÁLNÉ KANÓ I. (2005b): Az új gazdaságföldrajz modelljei. In Nagyné Fehér I. (szerk.): Erdei Ferenc III. Tudományos Konferencia, Kecskemét, II. kötet, 1030-1034. o.

SZAKÁLNÉ KANÓ I. (2008): A tudás-intenzív iparágak térbeli eloszlásának vizsgálata Magyarországon. A gazdasági környezet és a vállalati stratégiák, IX. Ipar és Vállalatgazdaságtani konferencia. Szeged, 587-600. o. 
SZAKÁLNÉ KANÓ I. (2009a): A tudás-intenzív szolgáltatások térbeli eloszlásának vizsgálata Magyarországon. In Hetesi E. - Majó Z. - Lukovics M. (szerk.): Szolgáltatások világa. JATEPress, Szeged, 201-222. o.

SZAKÁLNÉ KANÓ I. (2009b): An Analysis of the Spatial Distribution of Knowledge Intensive Services in Hungary. In Bajmócy Z.- Lengyel I. (eds): Regional competitiveness, innovation and environment. JATEPress, 122-141.o.

SZAKÁLNÉ KANÓ I. (2010): Magyar tudásintenzív ágazatok földrajzi eloszlásának vizsgálata. In „Félidőben” A Közép-Európai terület-, település-, vidék- és környezetfejlesztéssel foglalkozó doktori iskolák találkozója és konferenciája. Pécs, II. kötet, 266-279. o.

SZAKÁLNÉ KANÓ I. (2011): A gazdasági aktivitás térbeli eloszlásának vizsgálati lehetőségei. Statisztikai Szemle, 89. évf. 1. sz. 77-100. o.

SZAKÁLNÉ KANÓ I. (2012): Tudásintenzív ágazatok térbelisége: innováció és koncentráció. In Bajmócy Z. - Lengyel I. - Málovics Gy. (szerk.) Regionális innovációs képesség, versenyképesség és fenntarthatóság. JATEPress, Szeged, 109-131. o.

SZAKÁLNÉ KANÓ I. - VAS Zs. (2010): Do knowledge-intensive enterprises flock together? Evidence from Hungary at sub-regional level. Regional Studies Association Annual International Conference 2010. május 24-26. Pécs. http://www.regional-studiesassoc.ac.uk/events/2010/may-pecs/papers/Izabella.pdf

SZANYI M. - CSIZMADIA P. - ILlÉSSY M. - IWASAKI I. - MAKÓ Cs. (2009): A gazdasági tevékenység sürüsödési pontjainak (klaszterek) vizsgálata. Statisztikai Szemle, 87. évf. 9. sz. 921-937. o.

TóTH G. (2003): Területi autokorrelációs vizsgálat a Local Moran I módszerével. Tér és Társadalom, 17. évf. 4. sz. 39-49. o.

TÜÜ L.-NÉ (1980): Az ipari koncentráció mérése - Szakirodalmi tájékoztató. KSH Könyvtár és Dokumentáció Szolgálat, Budapest.

UsaI, S. - PACI, R. (2000): Externalities, Knowledge Spillovers And The Spatial Distribution Of Innovation. ERSA conference papers ersa00p104, European Regional Science Association.

VAN OORT, F. G. - ATZEMA, O. (2004): On the Conceptualization of Agglomeration Economies: The Case of new Firm Formation in the Dutch ICT Sector. The Annals of Regional Science, 38. évf. 2. sz. 263-290. o.

VARGA A. (1998): University Research and Regional Innovation: A Spatial Econometric Analysis of Academic Technology Transfers. Kluwer Academic Publishers, Boston

VARGA A. (2002): Térökonometria. Statisztikai Szemle, 80. évf. 4. sz. 354-370. o.

VARGA A. (2009): Térszerkezet és gazdasági növekedés. Akadémiai Kiadó, Budapest

YinG, G. E. - Ying-XIA, P. U. - SHI-MoU, Y. (2005): Measurement of Agglomeration Economies at County Level in Jiangsu Province. Chinese Geographical Science, 15. évf. 52-59. o. 
ZitT, M. - BARRÉ, R. - SigOgneaU, A. - LAVILle, F. (1999): Territorial concentration and evolution of science and technology activities in the European Union: a descriptive analysis. Research Policy, 5. sz. 545-562. o.

ZUCKER, L. G. - DARBY, M. R., (1996): Star scientists, institutions and the entry of Japanese biotech enterprises. NBER Working Paper No. 5795. 
Mellékletek 
I. melléklet: A feldolgozóipari alágazatok Moran index értékeinek becslése a megfelelö p-értékek segítségével
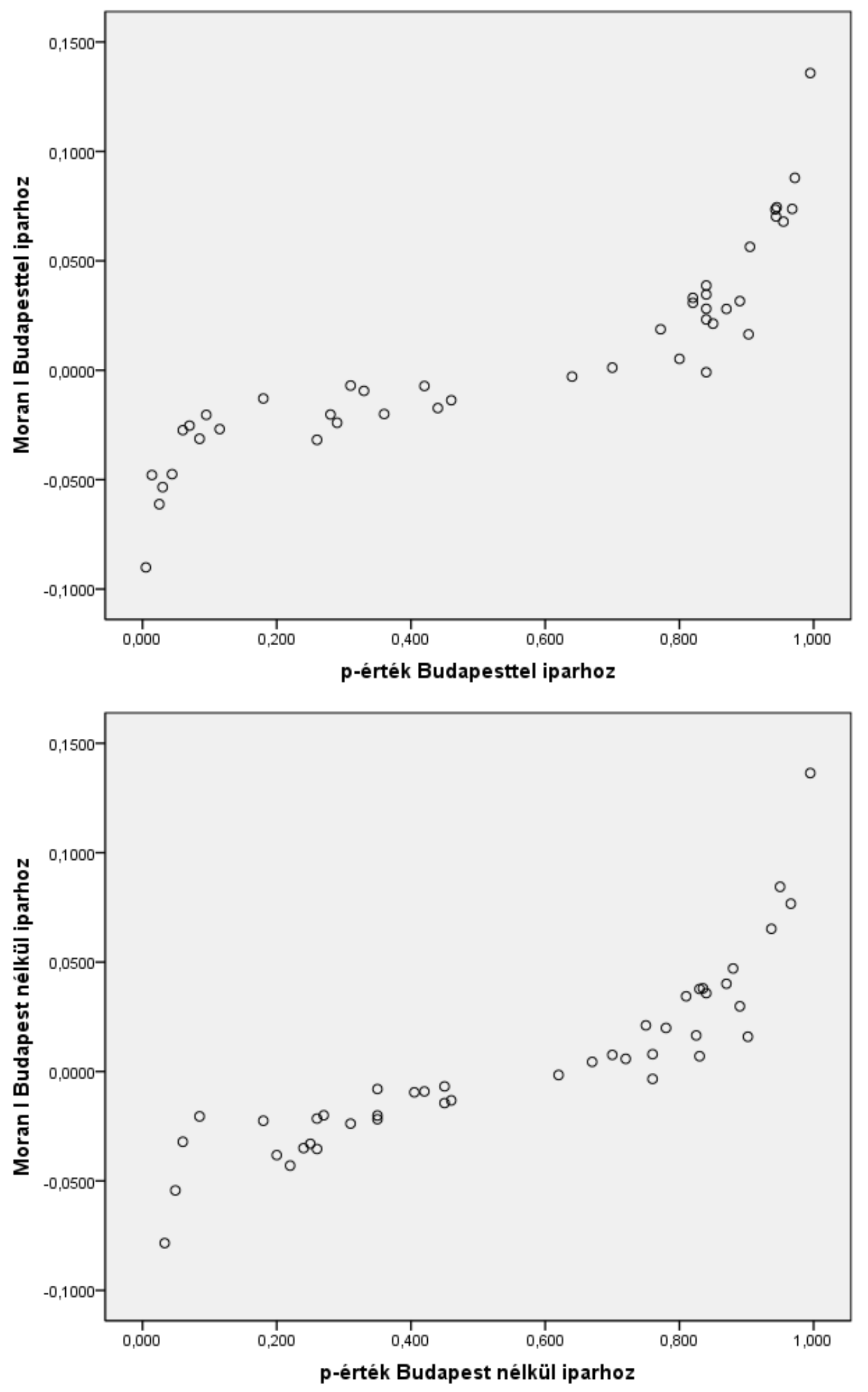

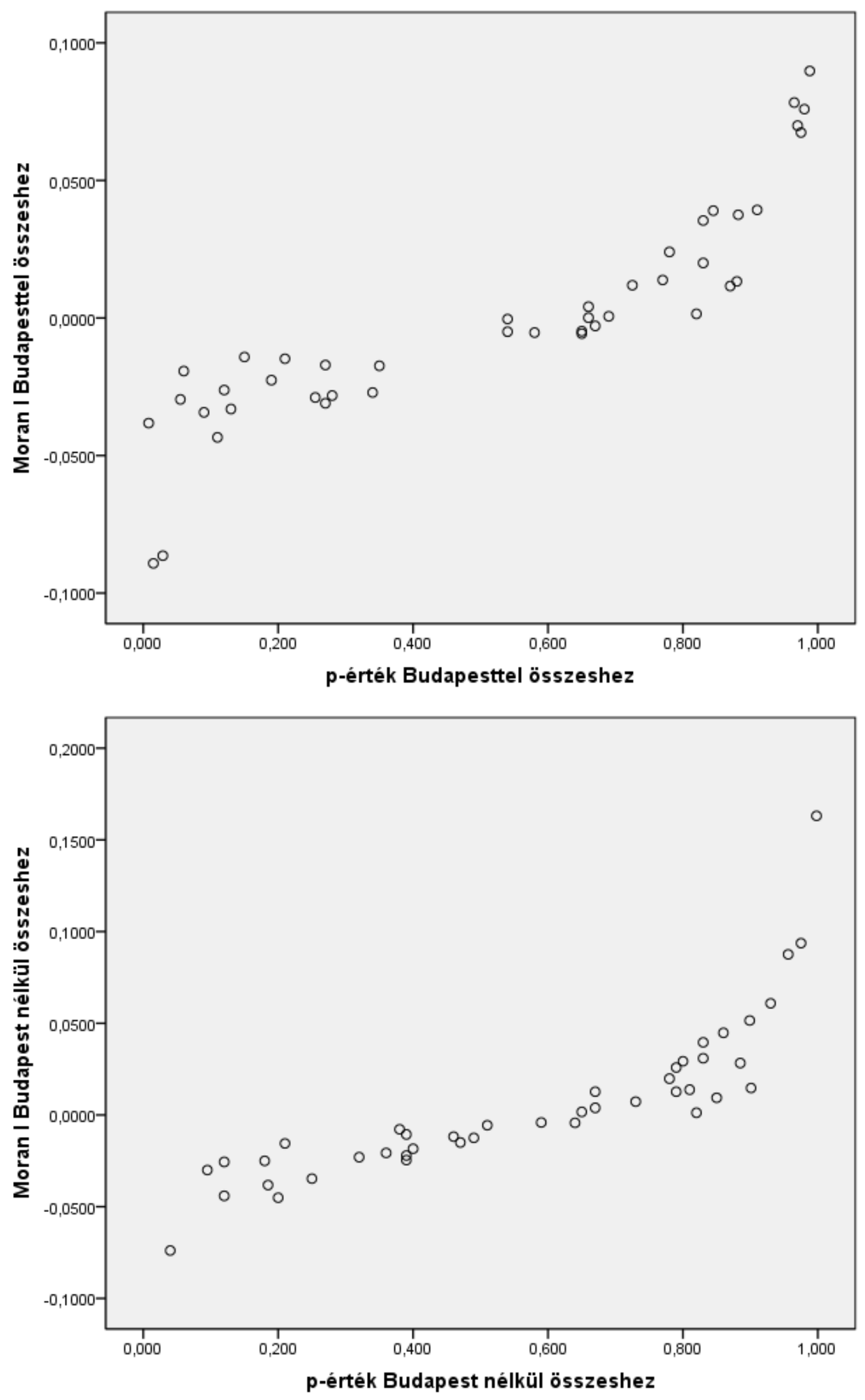

Az ábráknak megfelelően inverz logisztikus eloszlásfüggvény használatával becsültem a Moran index értékeket: 


\section{I. melléklet 1. tábla:}

Moran index Budapest adataival az iparban és építöiparban foglalkoztatottak eloszlásához képest (A BIPMoranI változó nemlineáris regressziós becslése a BipP változóval)

Paraméterek induló értéke: $\quad b 1=1, b 0=1$.

A becslöegyenlet: $\quad$ BIP $\overline{\text { Mor }} a n I=b 0+\operatorname{IDF}$. LOGISTIC (BipP, $-0.005988, b 1)$.

A várható érték: $\quad-0.005988=-\frac{1}{168-1}$.

A PASW Statistics 18 programban való számítások kimeneti táblái:

\section{Nonlinear Regression Analysis}

\begin{tabular}{|c|r|r|r|}
\hline \multirow{2}{*}{ Iteration Number } & \multirow{2}{*}{$\begin{array}{c}\text { Residual Sum } \\
\text { of Squares }\end{array}$} & \multicolumn{2}{|c|}{ Parameter } \\
\cline { 3 - 4 } & 299,959 & 1,000 & 1,000 \\
1.0 &, 010 &, 018 &, 010 \\
1.1 &, 010 &, 018 &, 010 \\
2.0 &, 010 &, 018 &, 010 \\
2.1 &
\end{tabular}

\begin{tabular}{|c|r|r|r|r|}
\hline \multirow{2}{*}{ Parameter } & & & \multicolumn{2}{|c|}{$95 \%$ Confidence Interval } \\
\cline { 4 - 5 } & Estimate & Std. Error & Lower Bound & Upper Bound \\
\hline b1 &, 018 &, 001 &, 016 &, 020 \\
b0 &, 010 &, 002 &, 005 &, 015 \\
\hline
\end{tabular}

\section{ANOVA $^{\mathrm{a}}$}

\begin{tabular}{|l|r|r|r|}
\hline Source & Sum of Squares & df & Mean Squares \\
\hline Regression &, 081 & 2 &, 040 \\
Residual &, 010 & 41 &, 000 \\
Uncorrected Total &, 090 & 43 & \\
Corrected Total &, 087 & 42 & \\
\hline
\end{tabular}

Dependent variable: BIPMoranl

a. $R$ squared $=1$ - (Residual Sum of Squares) / (Corrected Sum of Squares) $=, 889$.

A becslőegyenlet: $\quad$ BIP $\overline{\text { Mor }}$ anI $=0,01+I D F$. LOGISTIC (BipP, $-0.00578,0.018)$. Magyarázóerő: $\quad R^{2}=88,9 \%$ 


\section{I. melléklet 2. tábla:}

Moran index Budapest adataival a nemzetgazdaság egészében foglalkoztatottak eloszlásához képest (A BosMoranI változó nemlineáris regressziós becslése a BosP változóval)

Paraméterek induló értéke: $\quad b 1=1, b 0=1$.

A becslöegyenlet: $\quad$ Bos $\overline{\text { MoranI }}=b 0+\operatorname{IDF} \cdot \operatorname{LOGISTIC}(B$ osP $,-0.005988, b 1)$.

A várható érték: $\quad-0.005988=-\frac{1}{168-1}$.

A PASW Statistics 18 programban való számítások kimeneti táblái:

Nonlinear Regression Analysis

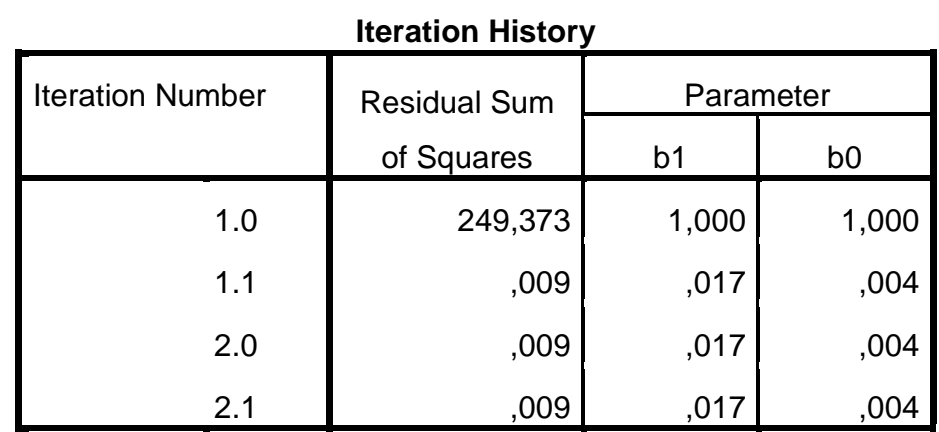

Parameter Estimates

\begin{tabular}{|c|r|r|r|r|}
\hline \multirow{2}{*}{ Parameter } & & & \multicolumn{2}{|c|}{$95 \%$ Confidence Interval } \\
\cline { 4 - 5 } & Estimate & Std. Error & Lower Bound & Upper Bound \\
\hline b1 &, 017 &, 001 &, 014 &, 019 \\
b0 &, 004 &, 002 &,- 001 &, 009 \\
\hline
\end{tabular}

ANOVA $^{a}$

\begin{tabular}{|l|r|r|r|}
\hline Source & Sum of Squares & df & Mean Squares \\
\hline Regression &, 056 & 2 &, 028 \\
Residual &, 009 & 41 &, 000 \\
Uncorrected Total &, 065 & 43 & \\
Corrected Total &, 065 & 42 & \\
\hline
\end{tabular}

Dependent variable: BosMoranl

a. $R$ squared $=1$ - (Residual Sum of Squares) / (Corrected Sum of Squares) $=, 861$.

A becslöegyenlet: $\quad$ Bos $\overline{M o r} a n I ~=0,004+I D F . \operatorname{LOGISTIC}(B o s P,-0.00578,0.017)$. Magyarázóerö: $\quad R^{2}=86,1 \%$ 


\section{I. melléklet 3. tábla:}

Moran index Budapest adatai nélkül az iparban és építőiparban foglalkoztatottak eloszlásához képest (A BnIPMoranI változó nemlineáris regressziós becslése a BnipP változóval)

Paraméterek induló

értéke:

$$
b 1=1, b 0=1 .
$$

A becslöegyenlet: $\quad$ BnI $\widehat{P M o r a n I}=b 0+I D F . \operatorname{LOGISTIC}(B n i p P,-0.006024, b 1)$.

A várható érték: $\quad-0.006024=-\frac{1}{167-1}$.

A PASW Statistics 18 programban való számítások kimeneti táblái:

\section{Nonlinear Regression Analysis}

\begin{tabular}{|r|r|r|r|}
\hline \multirow{2}{*}{ Iteration Number } & Residual Sum & \multicolumn{2}{|c|}{ Parameter } \\
\cline { 3 - 4 } & of Squares & \multicolumn{1}{|c|}{ b1 } & \multicolumn{1}{c|}{ b0 } \\
\hline 1.0 & 207,472 & 1,000 & 1,000 \\
1.1 &, 007 &, 021 &, 003 \\
2.0 &, 007 &, 021 &, 003 \\
2.1 &, 007 &, 021 &, 003 \\
\hline
\end{tabular}

Parameter Estimates

\begin{tabular}{|c|r|r|r|r|}
\hline \multirow{2}{*}{ Parameter } & & \multirow{2}{*}{} & \multicolumn{2}{|c|}{$95 \%$ Confidence Interval } \\
\cline { 4 - 5 } & Estimate & Std. Error & Lower Bound & Upper Bound \\
\hline b1 &, 021 &, 001 &, 019 &, 023 \\
b0 &, 003 &, 002 &,- 002 &, 007 \\
\hline
\end{tabular}

\section{ANOVA $^{\mathrm{a}}$}

\begin{tabular}{|l|r|r|r|}
\hline Source & Sum of Squares & df & Mean Squares \\
\hline Regression &, 061 & 2 &, 030 \\
Residual &, 007 & 41 &, 000 \\
Uncorrected Total &, 068 & 43 & \\
Corrected Total &, 068 & 42 & \\
\hline
\end{tabular}

Dependent variable: BnIPMoranl

a. R squared $=1$ - (Residual Sum of Squares) / (Corrected Sum of Squares) $=, 890$.

A becslőegyenlet:

$$
\text { BnIPMoranI }=0,003+\text { IDF. LOGISTIC (BnipP },-0.005814,0.021) \text {. }
$$

Magyarázóerő:

$$
R^{2}=89,0 \%
$$




\section{I. melléklet 4. tábla:}

Moran index Budapest adatai nélkül a nemzetgazdaság egészében foglalkoztatottak eloszlásához képest (A BnosMoranI változó nemlineáris regressziós becslése a BnosP változóval)

Paraméterek induló

értéke:

$$
b 1=1, b 0=1 .
$$

A becslöegyenlet: $\quad$ Bnos $\overline{M o r} a n I=b 0+\operatorname{IDF}$. LOGISTIC $($ BnosP $,-0.006024, b 1)$.

A várható érték: $\quad-0.006024=-\frac{1}{167-1}$.

A PASW Statistics 18 programban való számítások kimeneti táblái:

\section{Nonlinear Regression Analysis}

\begin{tabular}{|c|r|r|r|}
\hline \multirow{2}{*}{ Iteration Number } & Residual Sum & \multicolumn{2}{|c|}{ Parameter } \\
\cline { 3 - 4 } & of Squares & \multicolumn{1}{|c|}{ b1 } & \multicolumn{1}{c|}{ b0 } \\
\hline 1.0 & 219,464 & 1,000 & 1,000 \\
1.1 &, 007 &, 022 &, 001 \\
2.0 &, 007 &, 022 &, 001 \\
2.1 &, 007 &, 022 &, 001 \\
\hline
\end{tabular}

Parameter Estimates

\begin{tabular}{|c|r|r|r|r|}
\hline \multirow{2}{*}{ Parameter } & & & \multicolumn{2}{|c|}{$95 \%$ Confidence Interval } \\
\cline { 4 - 5 } & Estimate & Std. Error & Lower Bound & Upper Bound \\
\hline b1 &, 022 &, 001 &, 020 &, 025 \\
b0 &, 001 &, 002 &,- 004 &, 005 \\
\hline
\end{tabular}

ANOVA $^{\mathrm{a}}$

\begin{tabular}{|l|r|r|r|}
\hline Source & Sum of Squares & df & Mean Squares \\
\hline Regression &, 068 & 2 &, 034 \\
Residual &, 007 & 41 &, 000 \\
Uncorrected Total &, 075 & 43 & \\
Corrected Total &, 074 & 42 & \\
\hline
\end{tabular}

Dependent variable: BnosMoranl

a. $R$ squared $=1$ - (Residual Sum of Squares) / (Corrected Sum of

Squares) $=, 900$.

A becslőegyenlet:

$$
\text { BnosMoranI }=0,001+\operatorname{IDF} . \operatorname{LOGISTIC}(\text { BnosP },-0.005814,0.022) .
$$

Magyarázóerő: $\quad R^{2}=90,0 \%$ 


\section{II. melléklet: A tudásintenzív ágazatok térbeli eloszlásai térképeken, a kiszámolt mutatószám értékekkel}

\section{1. tábla: Jelmagyarázat}

- Minden oldalon két térkép és egy táblázat található.

- Feldolgozóipari ágazatok esetén (20-30 ágazatok) minden térkép és mutatószám kiszámítása az iparban és építöiparban foglalkoztatottak térbeli eloszlásához képest történt; szolgáltatási ágazatok esetén (51-80 ágazatok) minden térkép és mutatószám kiszámítása a szolgáltatásokban foglalkoztatottak térbeli eloszlásához képest történt.

- A felső térkép az adott ágazat Budapest adataival együtt számolt lokális mutatószámai (LISA index, LQ index) alapján készült.

- Az alsó térkép az adott ágazat Budapest adatai nélkül számolt lokális mutatószámai (LISA index, LQ index) alapján készült.

- A táblázat bal felső cellájában található az adott ágazat neve és 2-jegyü TEÁOR'08 kódja.

- A táblázatok cellái a megfelelő globális mutatók értékeitől függően színezettek:

- Moran index:

\begin{tabular}{|c|c|c|c|}
\hline Szín & Az ágazat & Moran index érték & p-érték \\
\hline & erősen negatívan autokorrelált & $I<-\frac{1}{M-1}$ & $p$ érték $<0,05$ \\
\hline & gyengén negatívan autokorrelált & $I<-\frac{1}{M-1}$ & $0,05<p$ érték $<0,1$ \\
\hline & nem autokorrelált & $I$ bármilyen & $0,1<p$ \\
\hline & gyengén pozitívan autokorrelált & $-\frac{1}{M-1}<I$ & $0,05<p$ érték $<0,1$ \\
\hline & erősen pozitívan autokorrelált & $-\frac{1}{M-1}<I$ & $p$ érték $<0,05$ \\
\hline
\end{tabular}

○ Ellison Glaeser $\gamma$ :

\begin{tabular}{|c|c|c|}
\hline Szín & Az ágazat & EG $\gamma$ érték \\
\hline & térben szétszórt & $\gamma<0$ \\
\hline & gyengén koncentrálódott & $0 \leq \gamma<0,02$ \\
\hline & közepesen koncentrálódott & $0,02 \leq \gamma<0,05$ \\
\hline & erösen koncentrálódott & $0,05 \leq \gamma$ \\
\hline
\end{tabular}

○ Normalizált Herfindahl index:

\begin{tabular}{|c|c|c|}
\hline Szín & Az ágazat & Normalizált Herfindahl index érték \\
\hline & erösen elaprózódott & $H^{*}<0,01$ \\
\hline & elaprózódott & $0,01<H^{*}<0,1$ \\
\hline & gyengén koncentrált & $0,1<H^{*}<0,18$ \\
\hline & erősen koncentrált & $0,18<H^{*}$ \\
\hline
\end{tabular}


II. melléklet 2. tábla:

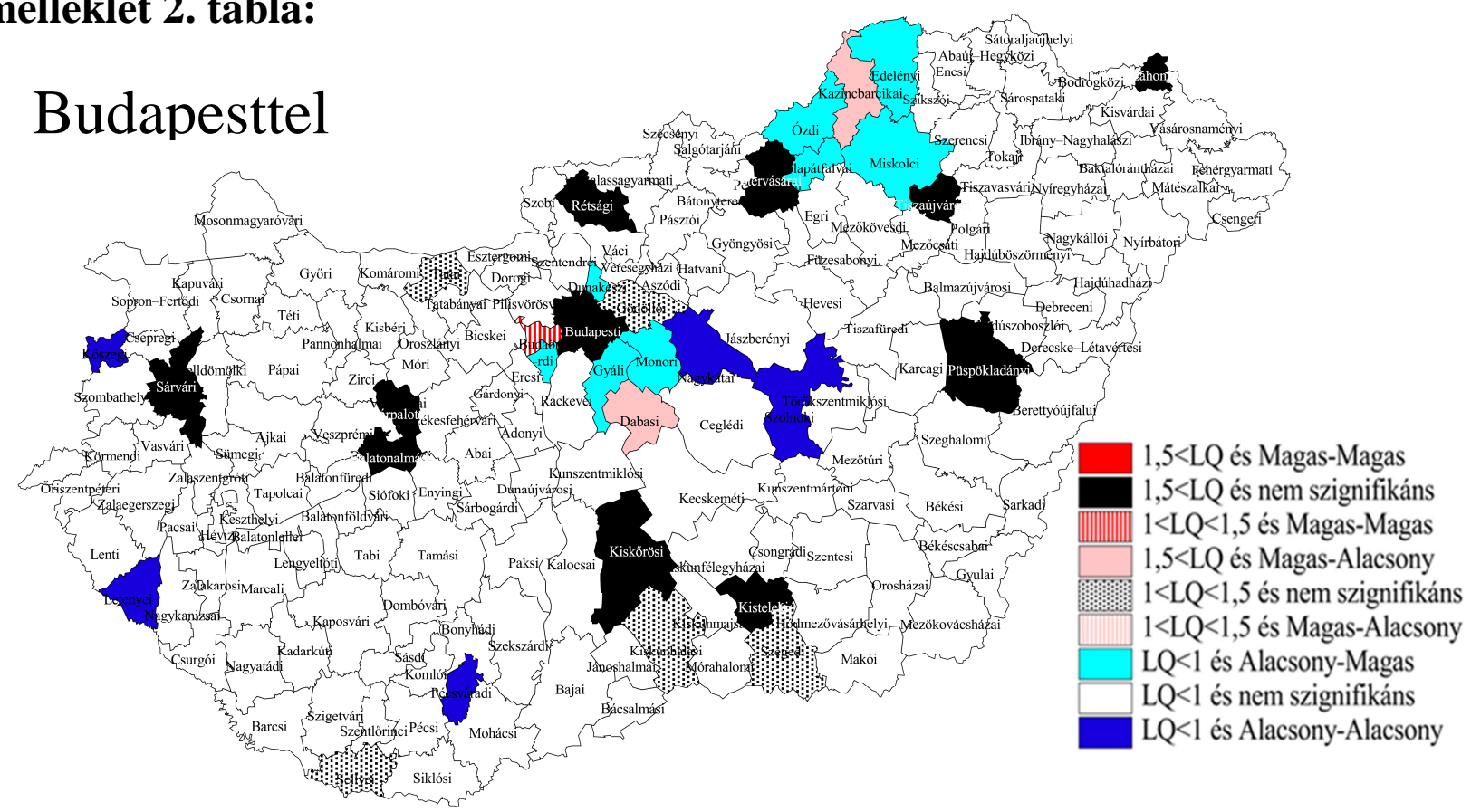

\begin{tabular}{|c|c|c|c|c|}
\hline \multirow[b]{2}{*}{$\begin{array}{l}20 \text { Vegyi anyag, } \\
\text { termék gyártása }\end{array}$} & \multicolumn{2}{|c|}{ Budapesttel } & \multicolumn{2}{|c|}{ Budapest nélkül } \\
\hline & $\begin{array}{c}\text { Iparban, } \\
\text { építőiparban } \\
\text { foglalkoztatottakhoz }\end{array}$ & $\begin{array}{c}\text { Nemzetgazdaság } \\
\text { egészében } \\
\text { foglalkoztatottakhoz }\end{array}$ & $\begin{array}{c}\text { Iparban, } \\
\text { építőiparban } \\
\text { foglalkoztatottakhoz }\end{array}$ & $\begin{array}{c}\text { Nemzetgazdaság } \\
\text { egészében } \\
\text { foglalkoztatottakhoz }\end{array}$ \\
\hline Átlagos méret (fö) & \multicolumn{2}{|c|}{36} & \multicolumn{2}{|c|}{39} \\
\hline Vállalkozások száma & \multicolumn{2}{|c|}{657} & \multicolumn{2}{|c|}{425} \\
\hline Moran index & $-0,036$ & $-0,045$ & $-0,032$ & $-0,037$ \\
\hline p érték & 0,073 & 0,021 & 0,065 & 0,038 \\
\hline EG $\gamma$ mutató & 0,047 & 0,032 & 0,038 & 0,041 \\
\hline $\begin{array}{l}\text { Normalizált } \\
\text { Herfindahl index }\end{array}$ & \multicolumn{2}{|c|}{0,063} & \multicolumn{2}{|c|}{0,115} \\
\hline
\end{tabular}

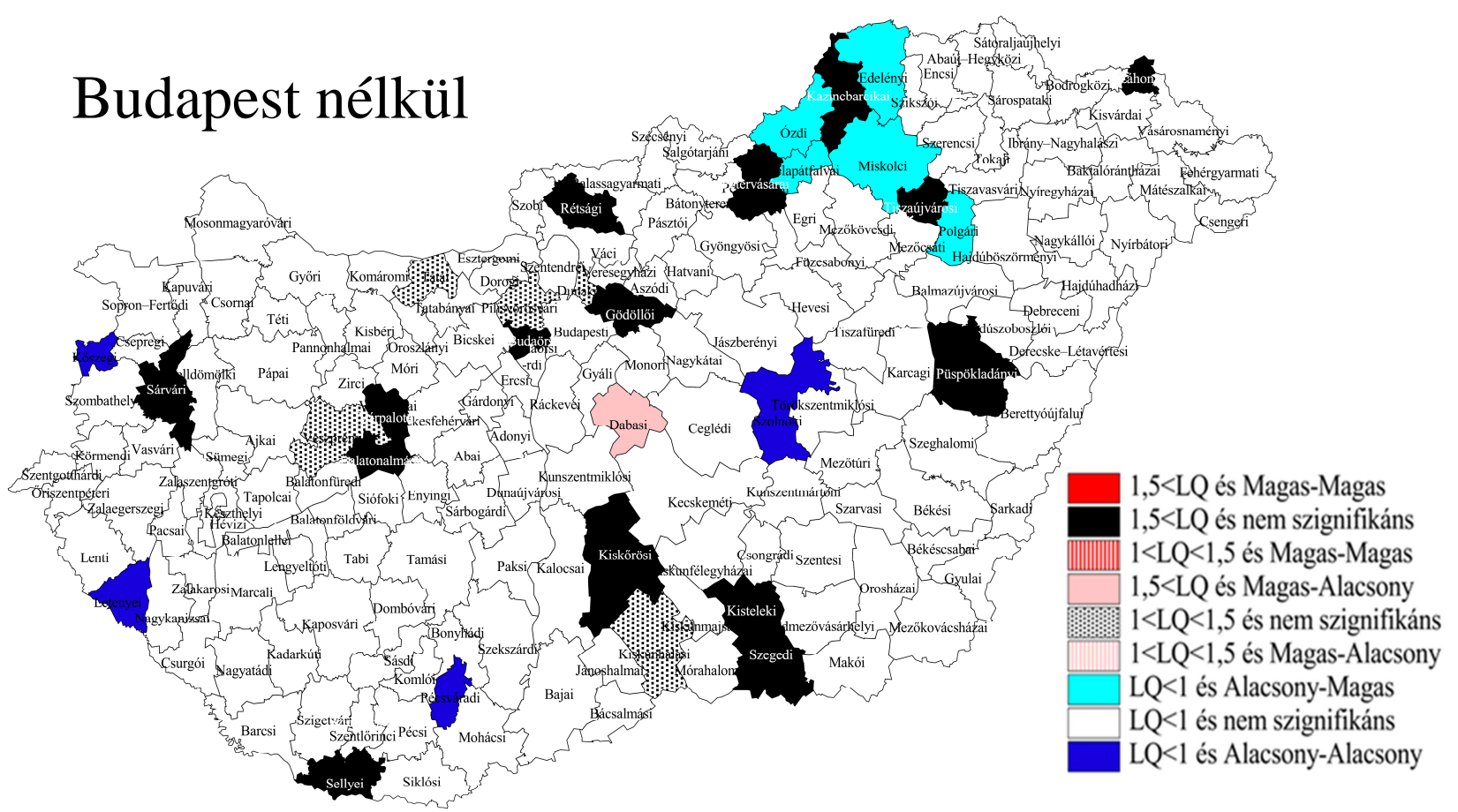




\section{II. melléklet 3. tábla:}

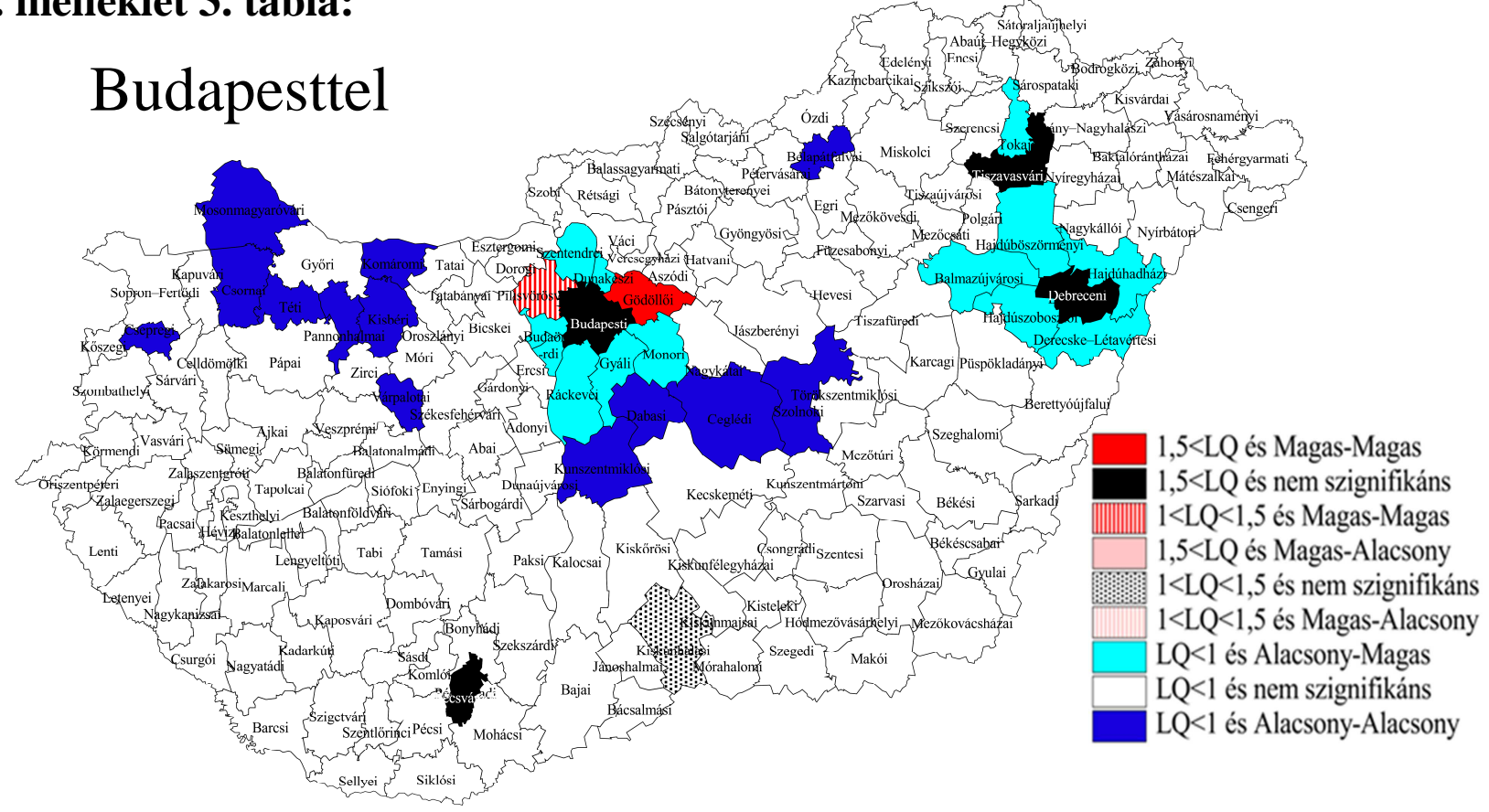

\begin{tabular}{|c|c|c|c|c|}
\hline \multirow[b]{2}{*}{$\begin{array}{c}21 \\
\text { Gyógyszergyártás }\end{array}$} & \multicolumn{2}{|c|}{ Budapesttel } & \multicolumn{2}{|c|}{ Budapest nélkül } \\
\hline & $\begin{array}{c}\text { Iparban, } \\
\text { építőiparban } \\
\text { foglalkoztatottakhoz }\end{array}$ & $\begin{array}{c}\text { Nemzetgazdaság } \\
\text { egészében } \\
\text { foglalkoztatottakhoz }\end{array}$ & $\begin{array}{c}\text { Iparban, } \\
\text { építőiparban } \\
\text { foglalkoztatottakhoz }\end{array}$ & $\begin{array}{l}\text { Nemzetgazdaság } \\
\text { egészében } \\
\text { foglalkoztatottakhoz }\end{array}$ \\
\hline Átlagos méret (fö) & \multicolumn{2}{|c|}{186} & \multicolumn{2}{|c|}{65} \\
\hline Vállalkozások száma & \multicolumn{2}{|c|}{112} & \multicolumn{2}{|c|}{55} \\
\hline Moran index & $-0,011$ & $-0,016$ & 0,004 & 0,003 \\
\hline p érték & 0,214 & 0,082 & 0,161 & 0,171 \\
\hline EG $\gamma$ mutató & 0,397 & 0,299 & $-0,009$ & $-0,018$ \\
\hline $\begin{array}{c}\text { Normalizált } \\
\text { Herfindahl index }\end{array}$ & \multicolumn{2}{|c|}{0,192} & \multicolumn{2}{|c|}{0,254} \\
\hline
\end{tabular}

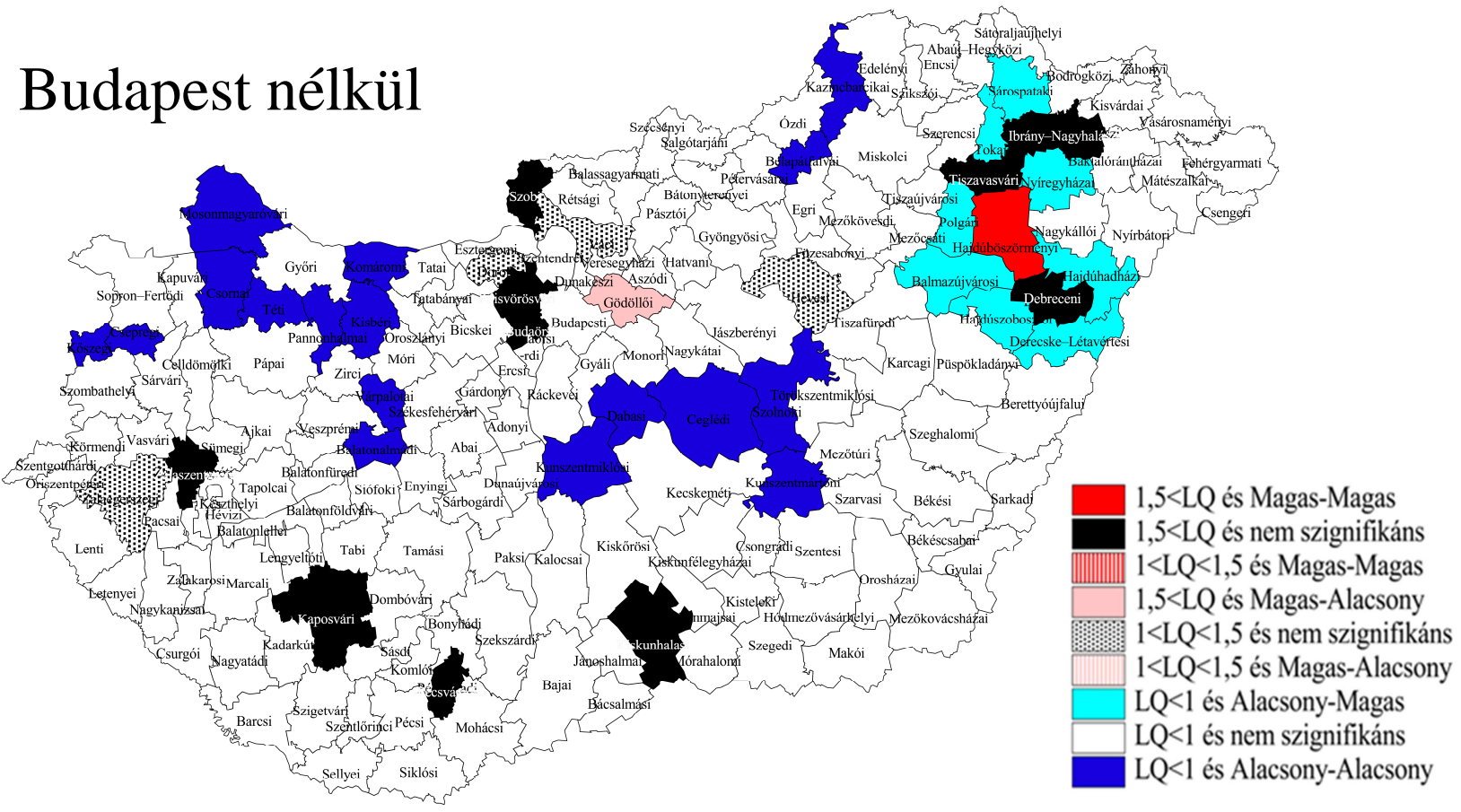




\section{II. melléklet 4. tábla:}

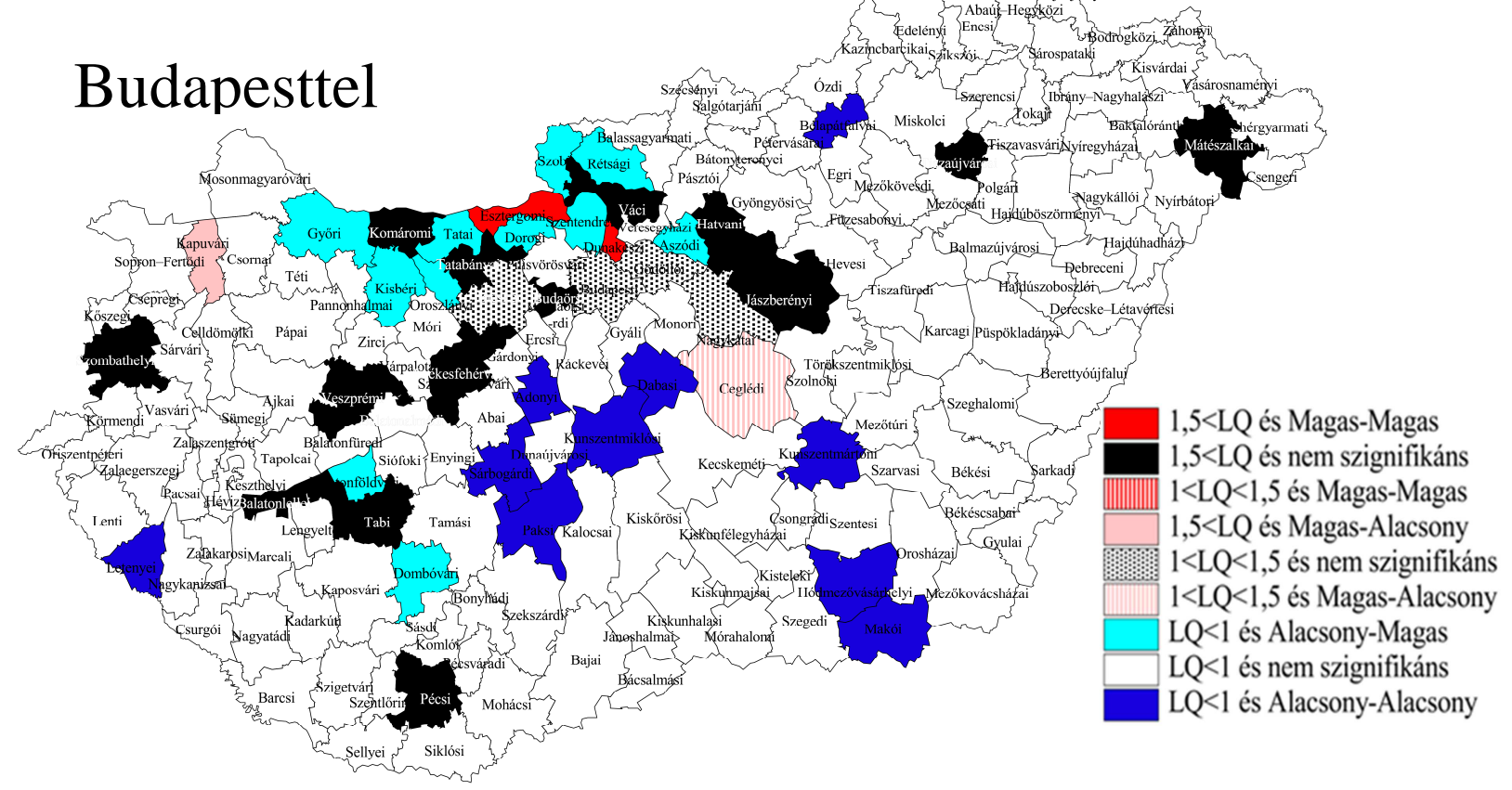

\begin{tabular}{|c|c|c|c|c|}
\hline \multirow{2}{*}{$\begin{array}{c}\text { 26 Számíttógép, } \\
\text { elektronikai, } \\
\text { optikai termék } \\
\text { gyártása }\end{array}$} & $\begin{array}{c}\text { Iparban, } \\
\text { építőiparban } \\
\text { foglalkoztatottakhoz }\end{array}$ & $\begin{array}{c}\text { Nemzetgazdaság } \\
\text { egészében } \\
\text { foglalkoztatottakhoz }\end{array}$ & $\begin{array}{c}\text { Iparban, } \\
\text { építöiparban } \\
\text { foglalkoztatottakhoz }\end{array}$ & $\begin{array}{c}\text { Nemzetgazdaság } \\
\text { egészében } \\
\text { foglalkoztatottakhoz }\end{array}$ \\
\hline Átlagos méret (fó) & \multicolumn{2}{|c|}{61} & \multicolumn{2}{c|}{97} \\
\hline Vállalkozások száma & \multicolumn{2}{|c|}{1765} & \multicolumn{2}{c|}{942} \\
\hline Moran index & $-0,009$ & 0,010 & $-0,008$ & 0,002 \\
\hline p érték & 0,464 & 0,305 & 0,439 & 0,366 \\
\hline EG $\gamma$ mutató & 0,009 & 0,013 & 0,012 & 0,014 \\
\hline $\begin{array}{c}\text { Normalizált } \\
\text { Herfindahl index }\end{array}$ & \multicolumn{2}{|c|}{0,036} \\
\hline
\end{tabular}

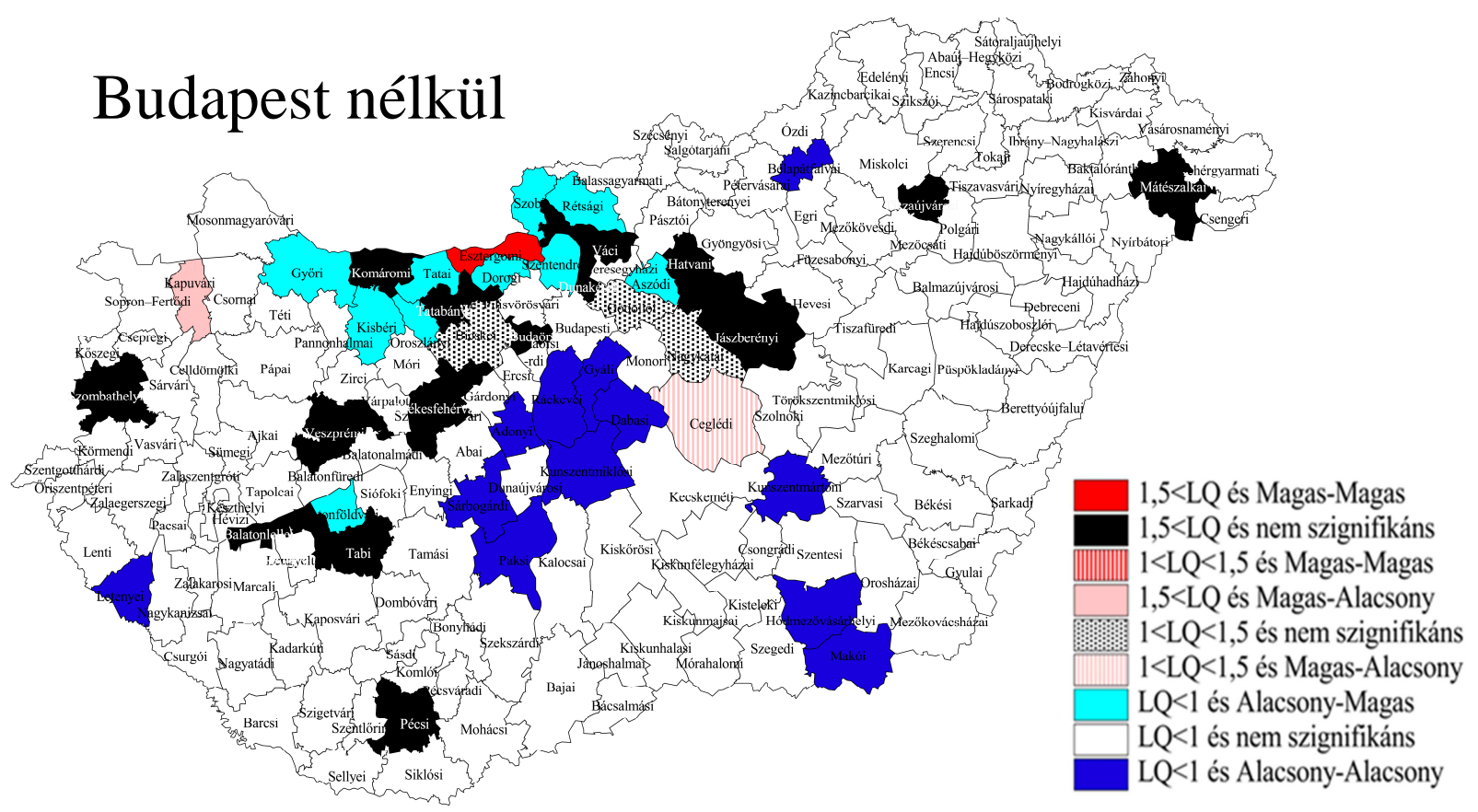




\section{II. melléklet 5. tábla:}

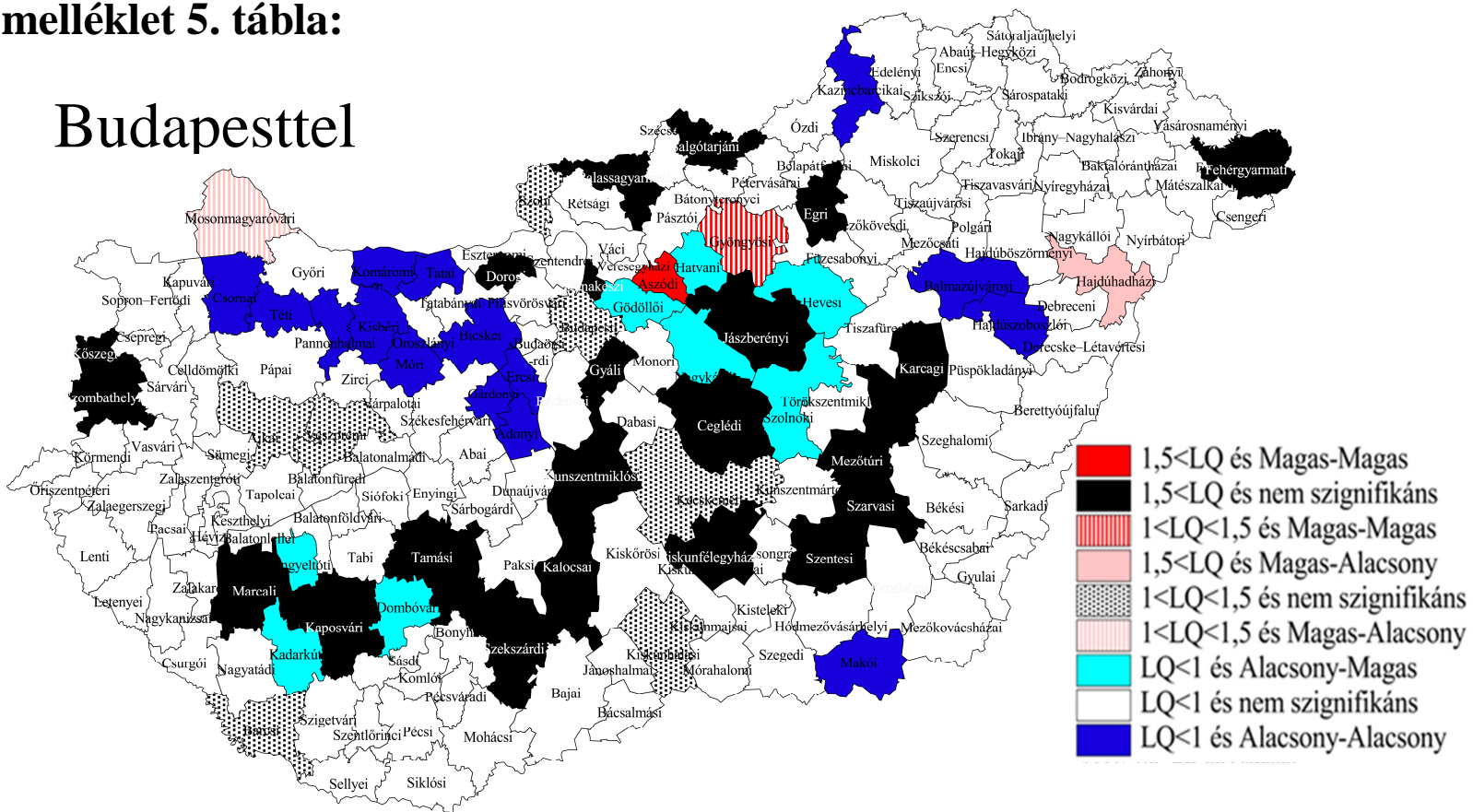

\begin{tabular}{|c|c|c|c|c|}
\hline \multirow[b]{2}{*}{$\begin{array}{l}27 \text { Villamos } \\
\text { berendezés } \\
\text { gyártása }\end{array}$} & \multicolumn{2}{|c|}{ Budapesttel } & \multicolumn{2}{|c|}{ Budapest nélkül } \\
\hline & $\begin{array}{c}\text { Iparban, } \\
\text { építöiparban } \\
\text { foglalkoztatottakhoz }\end{array}$ & $\begin{array}{c}\text { Nemzetgazdaság } \\
\text { egészében } \\
\text { foglalkoztatottakhoz }\end{array}$ & $\begin{array}{c}\text { Iparban, } \\
\text { építőiparban } \\
\text { foglalkoztatottakhoz }\end{array}$ & $\begin{array}{c}\text { Nemzetgazdaság } \\
\text { egészében } \\
\text { foglalkoztatottakhoz }\end{array}$ \\
\hline Átlagos méret (fö) & \multicolumn{2}{|c|}{53} & \multicolumn{2}{|c|}{72} \\
\hline Vállalkozások száma & \multicolumn{2}{|c|}{936} & \multicolumn{2}{|c|}{597} \\
\hline Moran index & 0,005 & 0,012 & 0,005 & 0,005 \\
\hline p érték & 0,312 & 0,258 & 0,308 & 0,306 \\
\hline EG $\gamma$ mutató & 0,018 & 0,022 & 0,024 & 0,026 \\
\hline $\begin{array}{c}\text { Normalizált } \\
\text { Herfindahl index }\end{array}$ & \multicolumn{2}{|c|}{0,021} & \multicolumn{2}{|c|}{0,027} \\
\hline
\end{tabular}

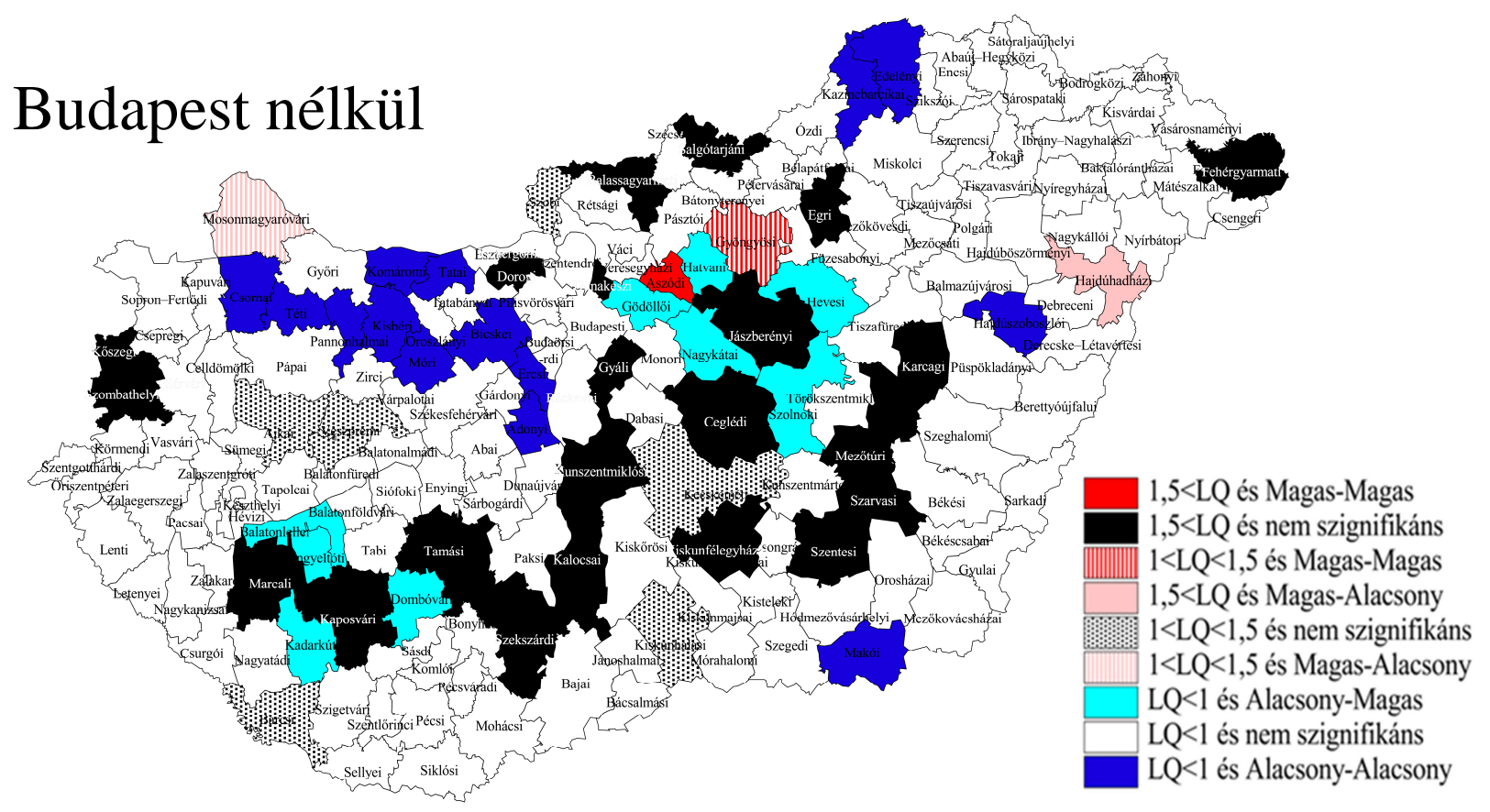




\section{II. melléklet 6. tábla:}

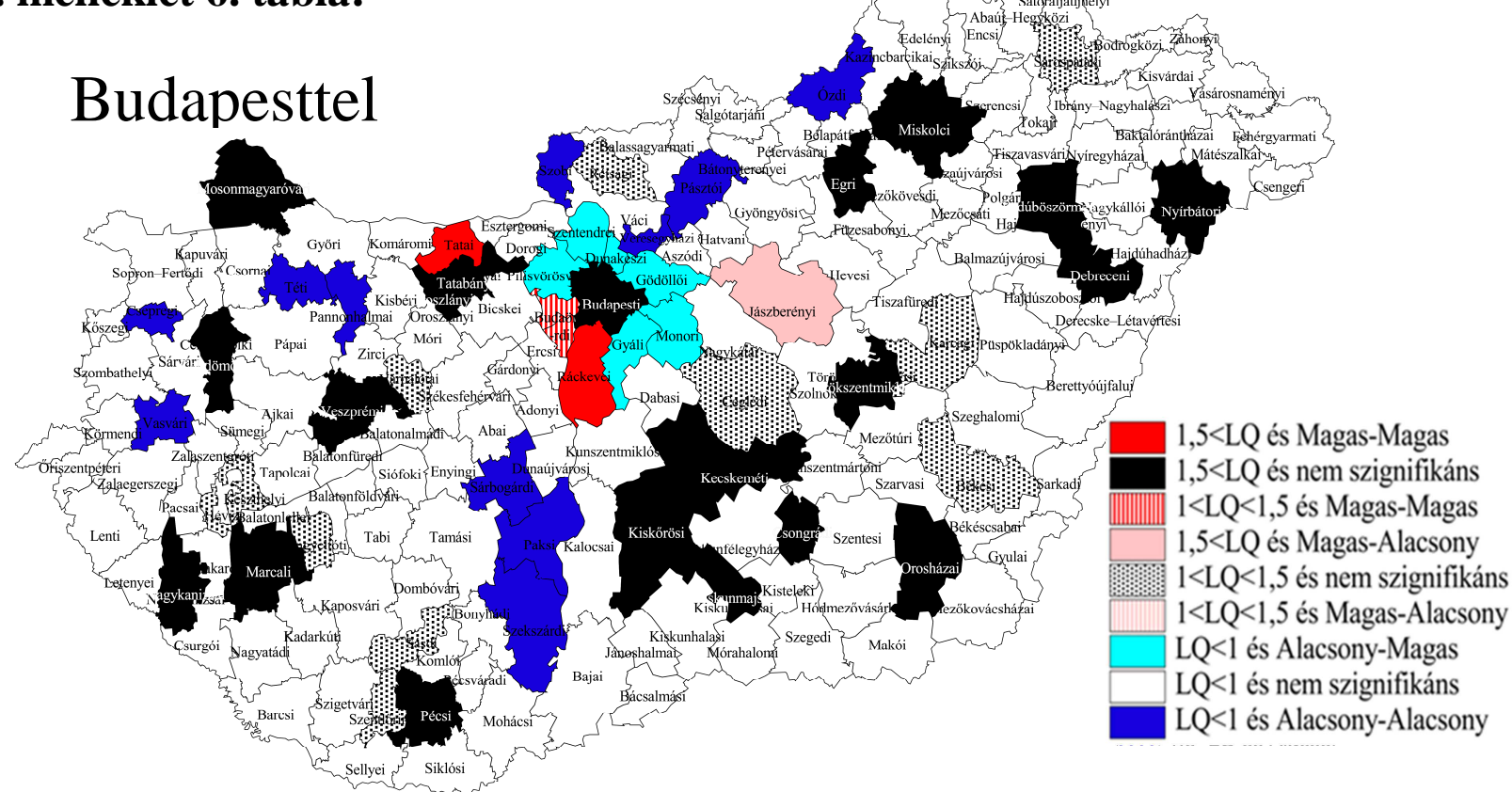

\begin{tabular}{|c|c|c|c|c|}
\hline \multirow[b]{2}{*}{$\begin{array}{l}28 \text { Gép, gépi } \\
\text { berendezés gyártása }\end{array}$} & \multicolumn{2}{|c|}{ Budapesttel } & \multicolumn{2}{|c|}{ Budapest nélkül } \\
\hline & $\begin{array}{c}\text { Iparban, } \\
\text { építöiparban } \\
\text { foglalkoztatottakhoz }\end{array}$ & $\begin{array}{l}\text { Nemzetgazdaság } \\
\text { egészében } \\
\text { foglalkoztatottakhoz }\end{array}$ & $\begin{array}{c}\text { Iparban, } \\
\text { építőiparban } \\
\text { foglalkoztatottakhoz }\end{array}$ & $\begin{array}{c}\text { Nemzetgazdaság } \\
\text { egészében } \\
\text { foglalkoztatottakhoz }\end{array}$ \\
\hline Átlagos méret (fö) & \multicolumn{2}{|c|}{26} & \multicolumn{2}{|c|}{27} \\
\hline Vállalkozások száma & \multicolumn{2}{|c|}{2803} & \multicolumn{2}{|c|}{1967} \\
\hline Moran index & $-0,016$ & $-0,027$ & $-0,027$ & $-0,004$ \\
\hline p érték & 0,440 & 0,335 & 0,343 & 0,448 \\
\hline EG $\gamma$ mutató & 0,009 & $-0,005$ & 0,001 & 0,001 \\
\hline $\begin{array}{c}\text { Normalizált } \\
\text { Herfindahl index }\end{array}$ & \multicolumn{2}{|c|}{0,018} & \multicolumn{2}{|c|}{0,011} \\
\hline
\end{tabular}

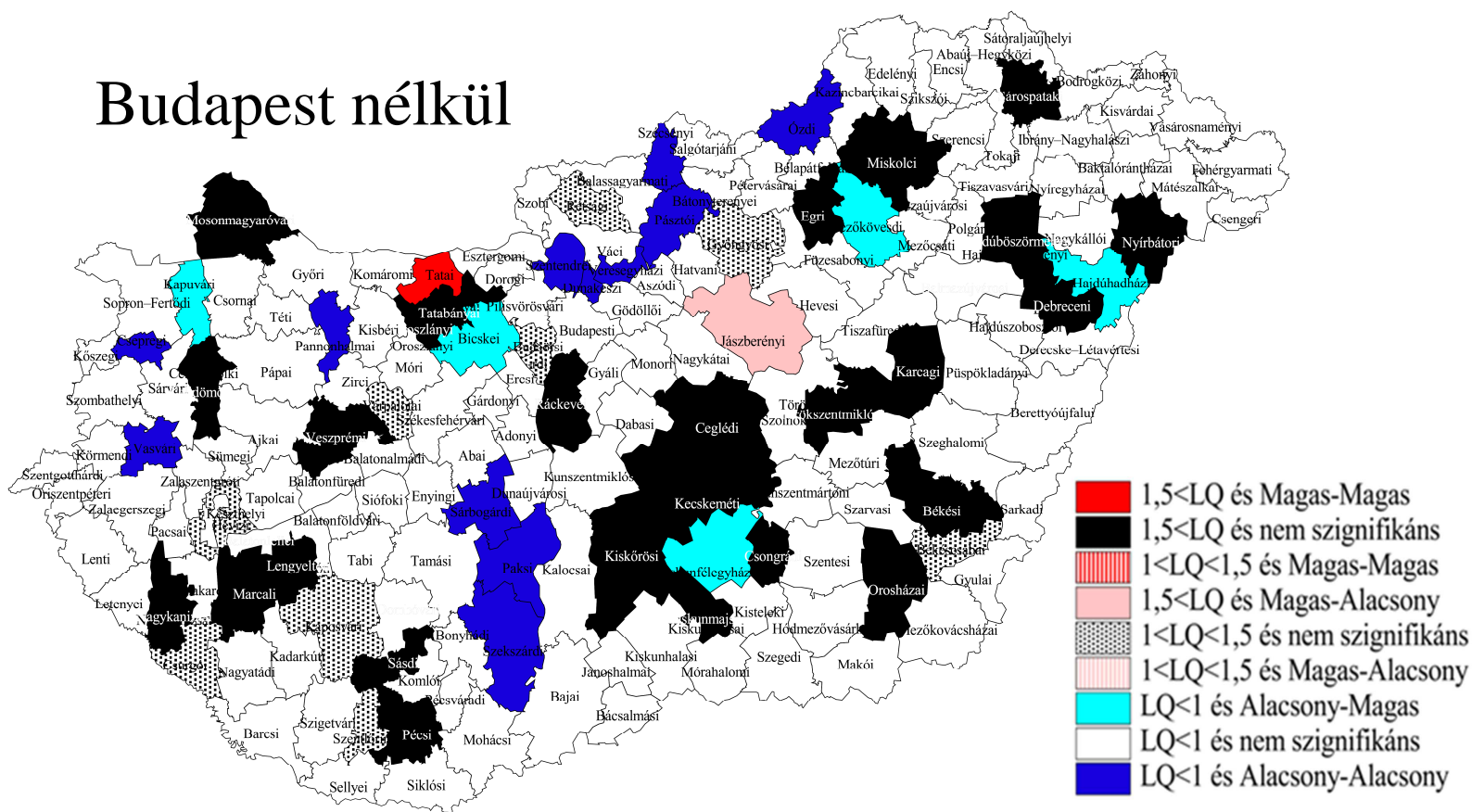




\section{II. melléklet 7. tábla:}

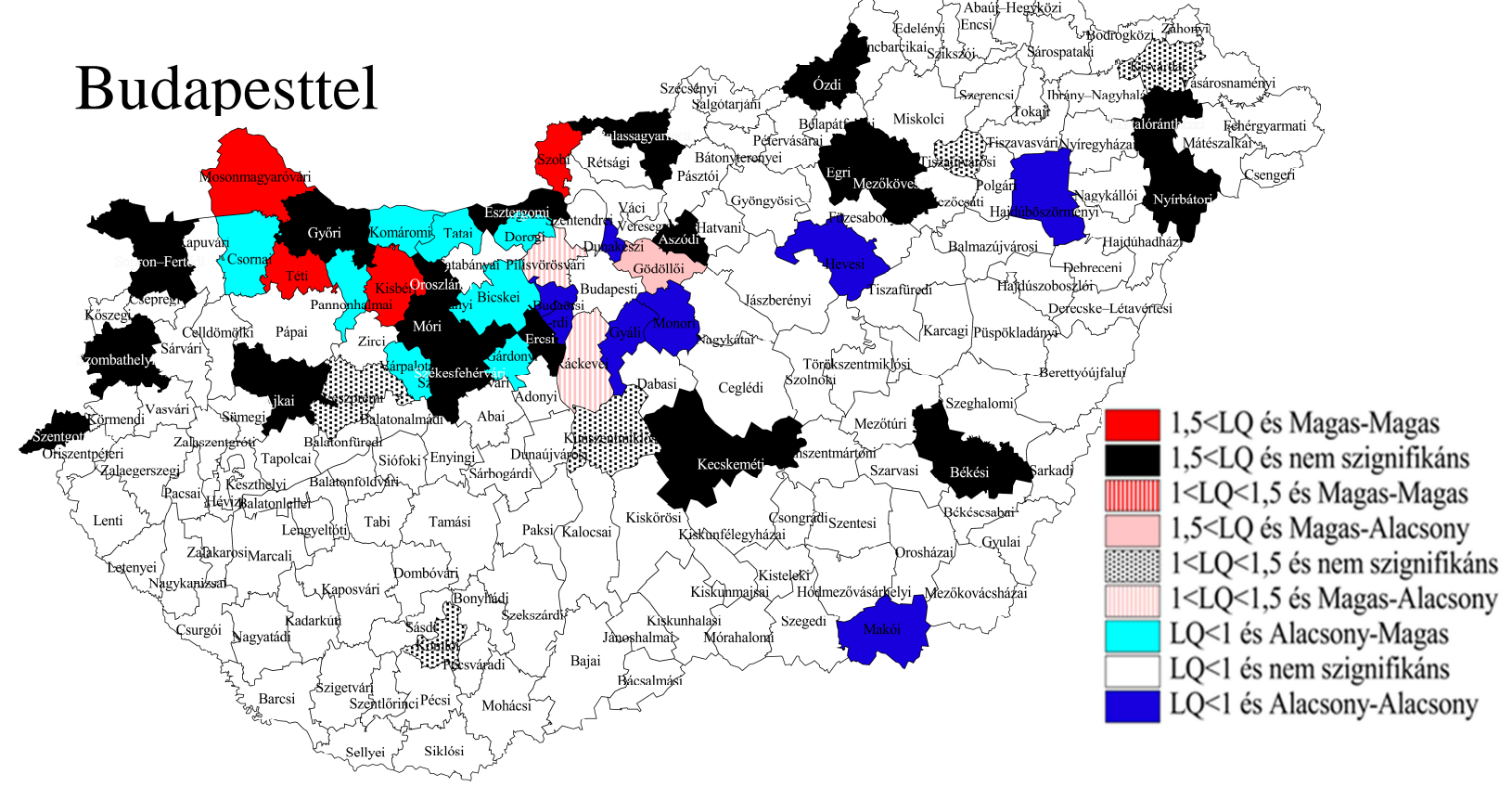

\begin{tabular}{|c|c|c|c|c|}
\hline \multirow[b]{2}{*}{$\begin{array}{l}29 \text { Közúti jármü } \\
\text { gyártása }\end{array}$} & \multicolumn{2}{|c|}{ Budapesttel } & \multicolumn{2}{|c|}{ Budapest nélkül } \\
\hline & $\begin{array}{c}\text { Iparban, } \\
\text { építőiparban } \\
\text { foglalkoztatottakhoz }\end{array}$ & $\begin{array}{c}\text { Nemzetgazdaság } \\
\text { egészében } \\
\text { foglalkoztatottakhoz }\end{array}$ & $\begin{array}{c}\text { Iparban, } \\
\text { építőiparban } \\
\text { foglalkoztatottakhoz }\end{array}$ & $\begin{array}{l}\text { Nemzetgazdaság } \\
\text { egészében } \\
\text { foglalkoztatottakhoz }\end{array}$ \\
\hline Átlagos méret (fö) & \multicolumn{2}{|c|}{168} & \multicolumn{2}{|c|}{200} \\
\hline Vállalkozások száma & \multicolumn{2}{|c|}{464} & \multicolumn{2}{|c|}{377} \\
\hline Moran index & 0,034 & 0,043 & 0,040 & 0,061 \\
\hline p érték & 0,146 & 0,097 & 0,127 & 0,082 \\
\hline EG $\gamma$ mutató & 0,024 & 0,043 & 0,017 & 0,020 \\
\hline $\begin{array}{l}\text { Normalizált } \\
\text { Herfindahl index }\end{array}$ & \multicolumn{2}{|c|}{0,029} & \multicolumn{2}{|c|}{0,031} \\
\hline
\end{tabular}

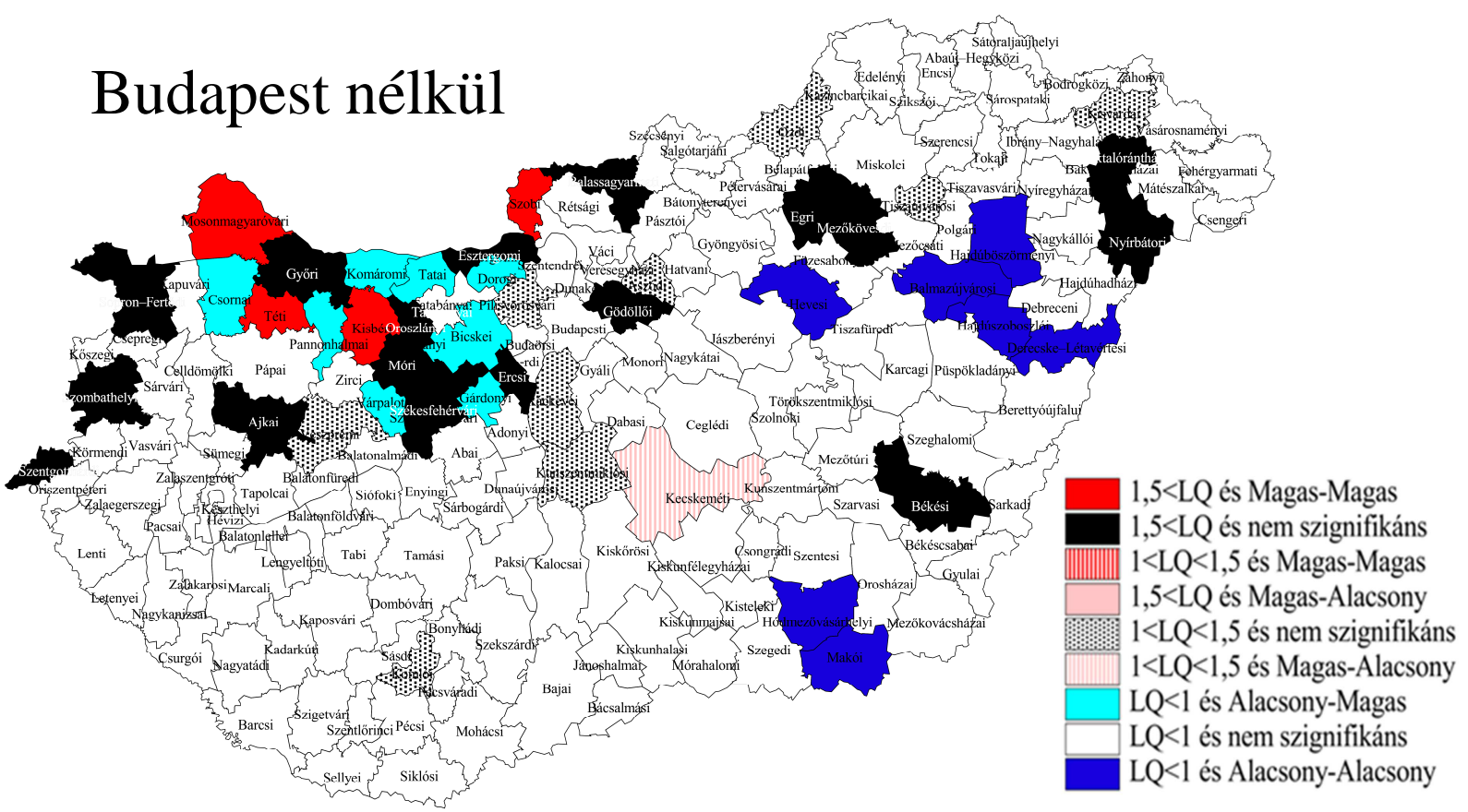




\section{II. melléklet 8. tábla:}

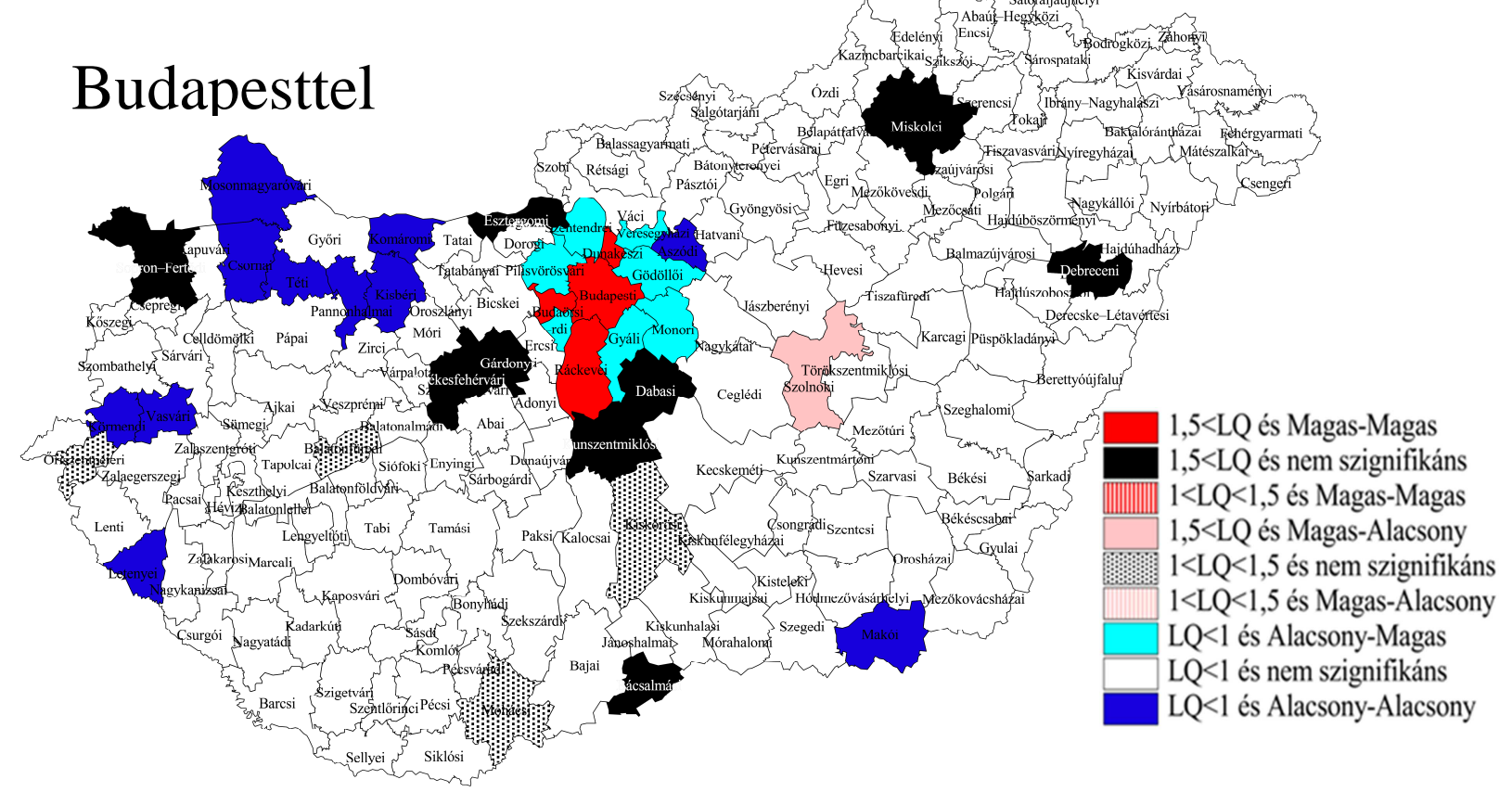

\begin{tabular}{|c|c|c|c|c|}
\hline \multirow{2}{*}{$\begin{array}{c}\text { 30 Egyéb jármú } \\
\text { gyártása }\end{array}$} & $\begin{array}{c}|c| \\
\text { Ipudarban, } \\
\text { fepítőiparban } \\
\text { foglalkoztatottakhoz }\end{array}$ & $\begin{array}{c}\text { Nemzetgazdaság } \\
\text { egészében } \\
\text { foglalkoztatottakhoz }\end{array}$ & $\begin{array}{c}\text { Bparban, } \\
\text { építőiparban } \\
\text { foglalkoztatottakhoz }\end{array}$ & $\begin{array}{c}\text { Nemzetgazdaság } \\
\text { egészében } \\
\text { foglalkoztatottakhoz }\end{array}$ \\
\hline Átlagos méret (fö) & \multicolumn{2}{|c|}{29} & \multicolumn{2}{c|}{27} \\
\hline Vállalkozások száma & \multicolumn{2}{|c|}{279} & \multicolumn{2}{c|}{165} \\
\hline Moran index & 0,094 & 0,093 & $-0,030$ & $-0,034$ \\
\hline p érték & 0,025 & 0,032 & 0,248 & 0,166 \\
\hline EG $\gamma$ mutató & 0,057 & 0,022 & $-0,001$ & $-0,005$ \\
\hline $\begin{array}{c}\text { Normalizált } \\
\text { Herfindahl index }\end{array}$ & \multicolumn{2}{|c|}{0,093} \\
\hline
\end{tabular}

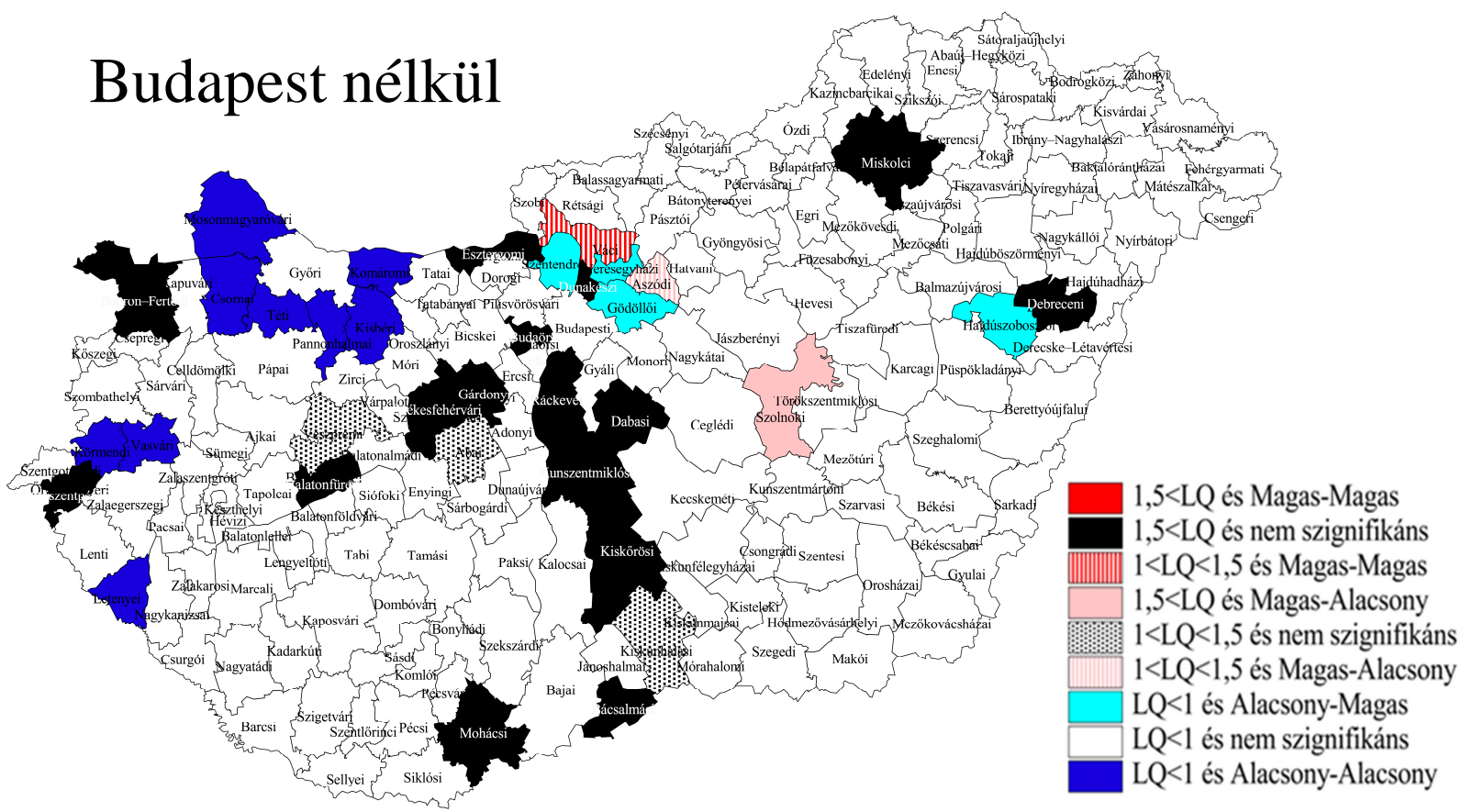




\section{II. melléklet 9. tábla:}

\section{Budapesttel}

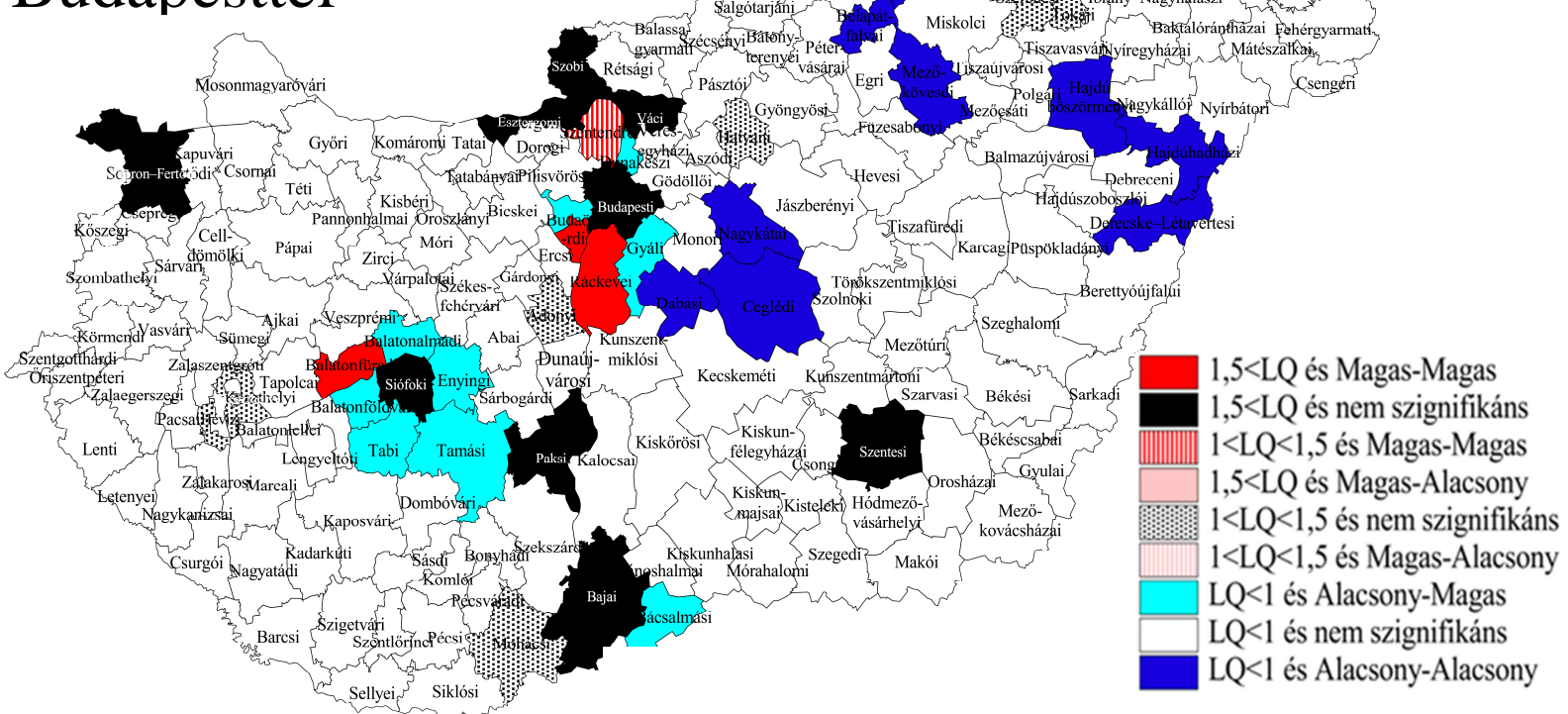

\begin{tabular}{|c|c|c|c|c|}
\hline \multirow[b]{2}{*}{50 Vízi szálítás } & \multicolumn{2}{|c|}{ Budapesttel } & \multicolumn{2}{|c|}{ Budapest nélkül } \\
\hline & $\begin{array}{c}\text { Iparban, } \\
\text { építőiparban } \\
\text { foglalkoztatottakhoz }\end{array}$ & $\begin{array}{c}\text { Nemzetgazdaság } \\
\text { egészében } \\
\text { foglalkoztatottakhoz }\end{array}$ & $\begin{array}{c}\text { Iparban, } \\
\text { építőiparban } \\
\text { foglalkoztatottakhoz }\end{array}$ & $\begin{array}{c}\text { Nemzetgazdaság } \\
\text { egészében } \\
\text { foglalkoztatottakhoz }\end{array}$ \\
\hline Átlagos méret (fö) & \multicolumn{2}{|c|}{17} & \multicolumn{2}{|c|}{15} \\
\hline Vállalkozások száma & \multicolumn{2}{|c|}{123} & \multicolumn{2}{|c|}{71} \\
\hline Moran index & 0,006 & 0,009 & 0,015 & 0,015 \\
\hline p érték & 0,144 & 0,125 & 0,099 & 0,092 \\
\hline EG $\gamma$ mutató & 0,011 & 0,033 & 0,009 & 0,008 \\
\hline $\begin{array}{c}\text { Normalizált } \\
\text { Herfindahl index }\end{array}$ & \multicolumn{2}{|c|}{0,129} & \multicolumn{2}{|c|}{0,272} \\
\hline
\end{tabular}

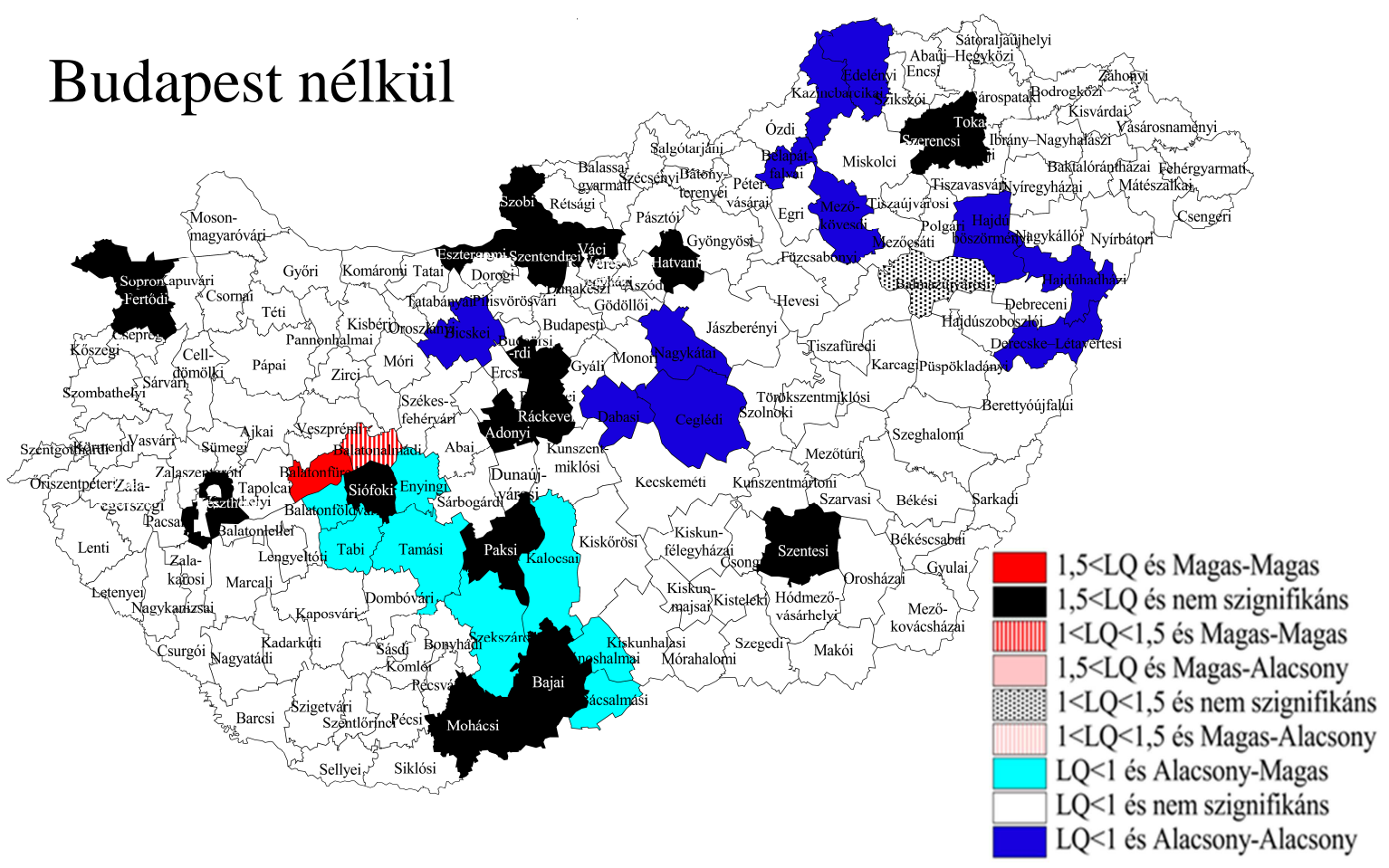


II. melléklet 10. tábla:

Budapesttel

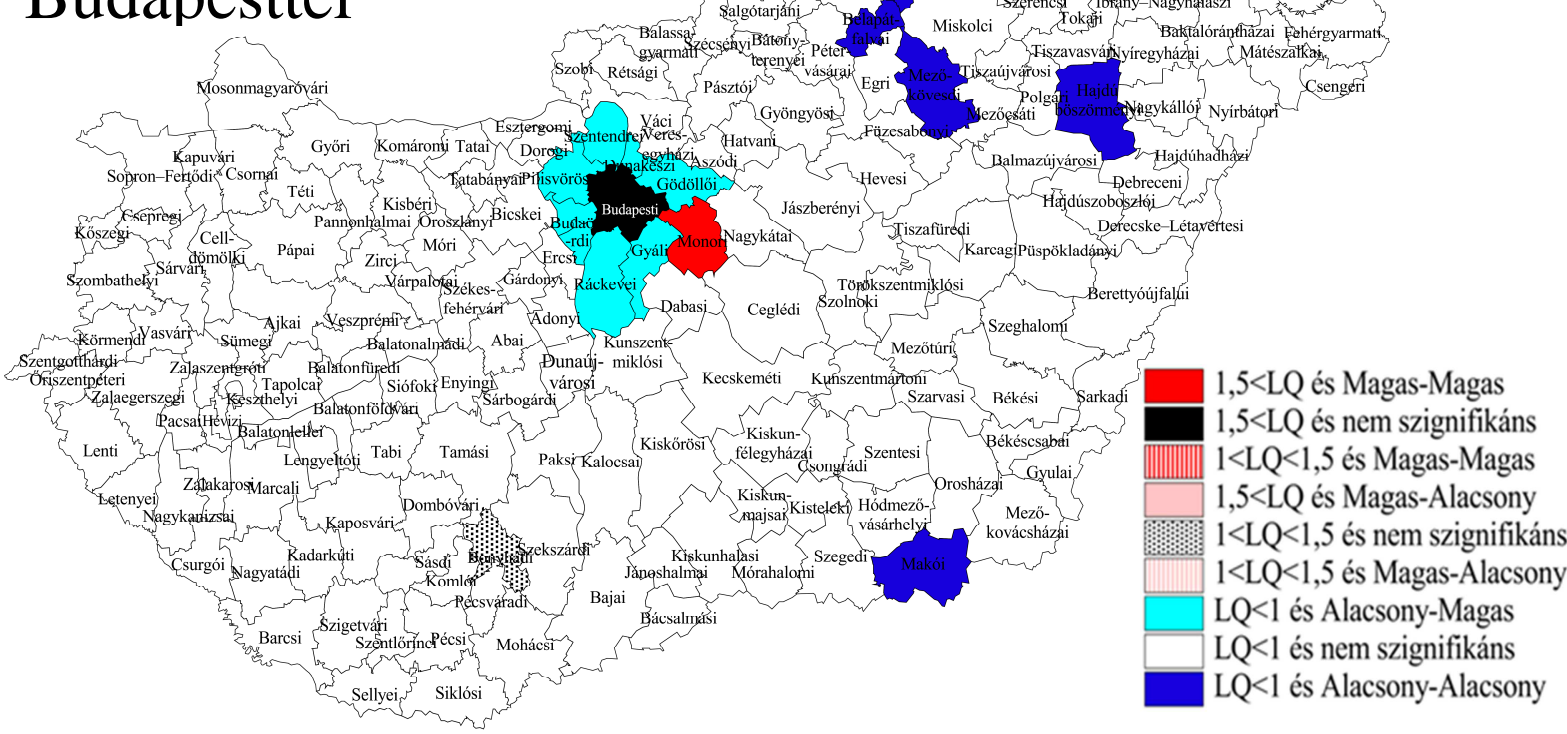

\begin{tabular}{|c|c|c|c|c|}
\hline \multirow[b]{2}{*}{51 Légi szállítás } & \multicolumn{2}{|c|}{ Budapesttel } & \multicolumn{2}{|c|}{ Budapest nélkül } \\
\hline & $\begin{array}{c}\text { Iparban, } \\
\text { építőiparban } \\
\text { foglalkoztatottakhoz }\end{array}$ & $\begin{array}{l}\text { Nemzetgazdaság } \\
\text { egészében } \\
\text { foglalkoztatottakhoz }\end{array}$ & $\begin{array}{c}\text { Iparban, } \\
\text { építőiparban } \\
\text { foglalkoztatottakhoz }\end{array}$ & $\begin{array}{l}\text { Nemzetgazdaság } \\
\text { egészében } \\
\text { foglalkoztatottakhoz }\end{array}$ \\
\hline Átlagos méret (fö) & \multicolumn{2}{|c|}{39} & \multicolumn{2}{|c|}{14} \\
\hline Vállalkozások száma & \multicolumn{2}{|c|}{121} & \multicolumn{2}{|c|}{50} \\
\hline Moran index & 0,019 & 0,022 & $-0,012$ & $-0,010$ \\
\hline p érték & 0,034 & 0,032 & 0,185 & 0,225 \\
\hline EG $\gamma$ mutató & 0,014 & 0,112 & 0,465 & 0,466 \\
\hline $\begin{array}{c}\text { Normalizált } \\
\text { Herfindahl index }\end{array}$ & \multicolumn{2}{|c|}{0,422} & \multicolumn{2}{|c|}{0,269} \\
\hline
\end{tabular}

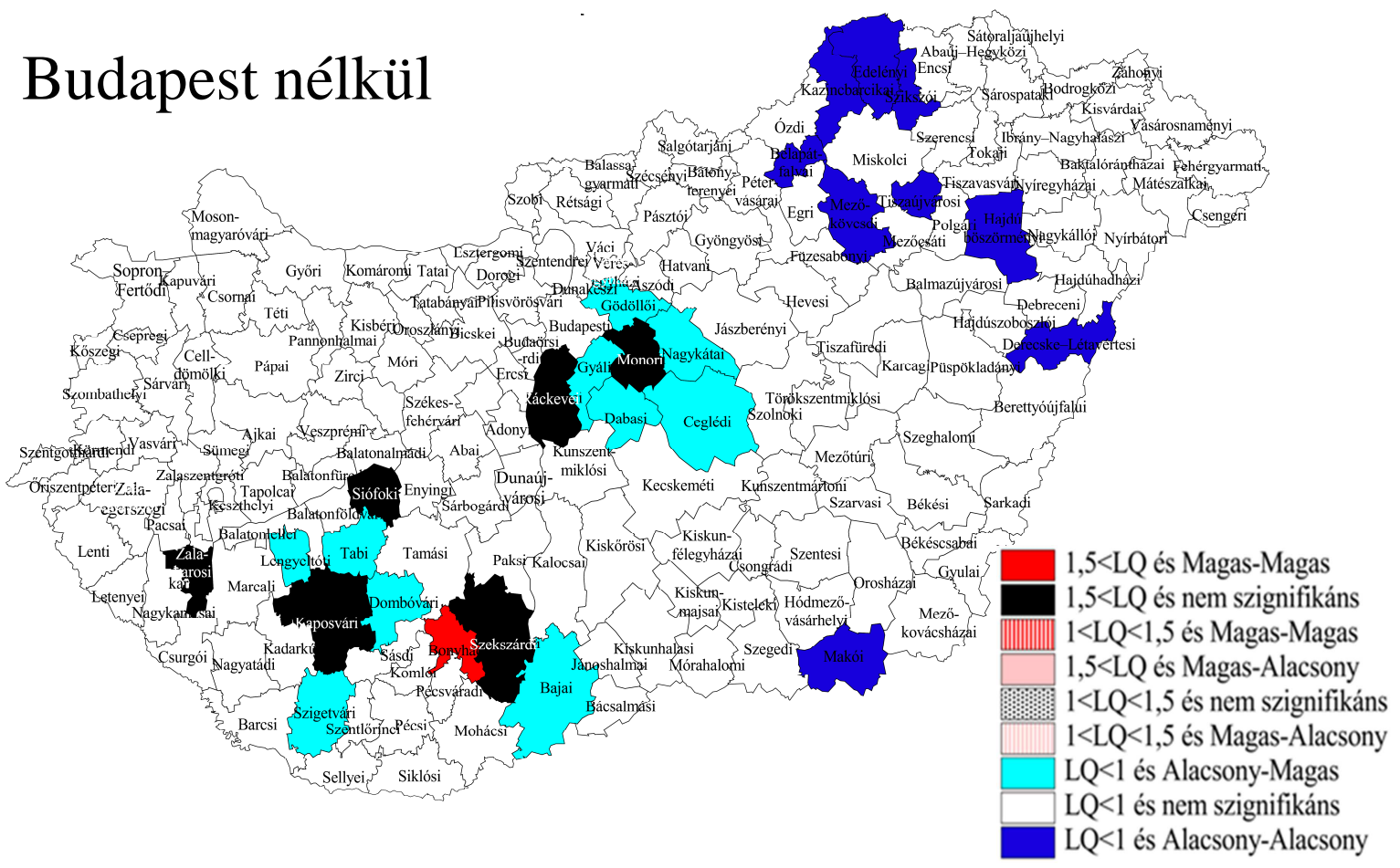


II. melléklet 11. tábla:

Budapesttel

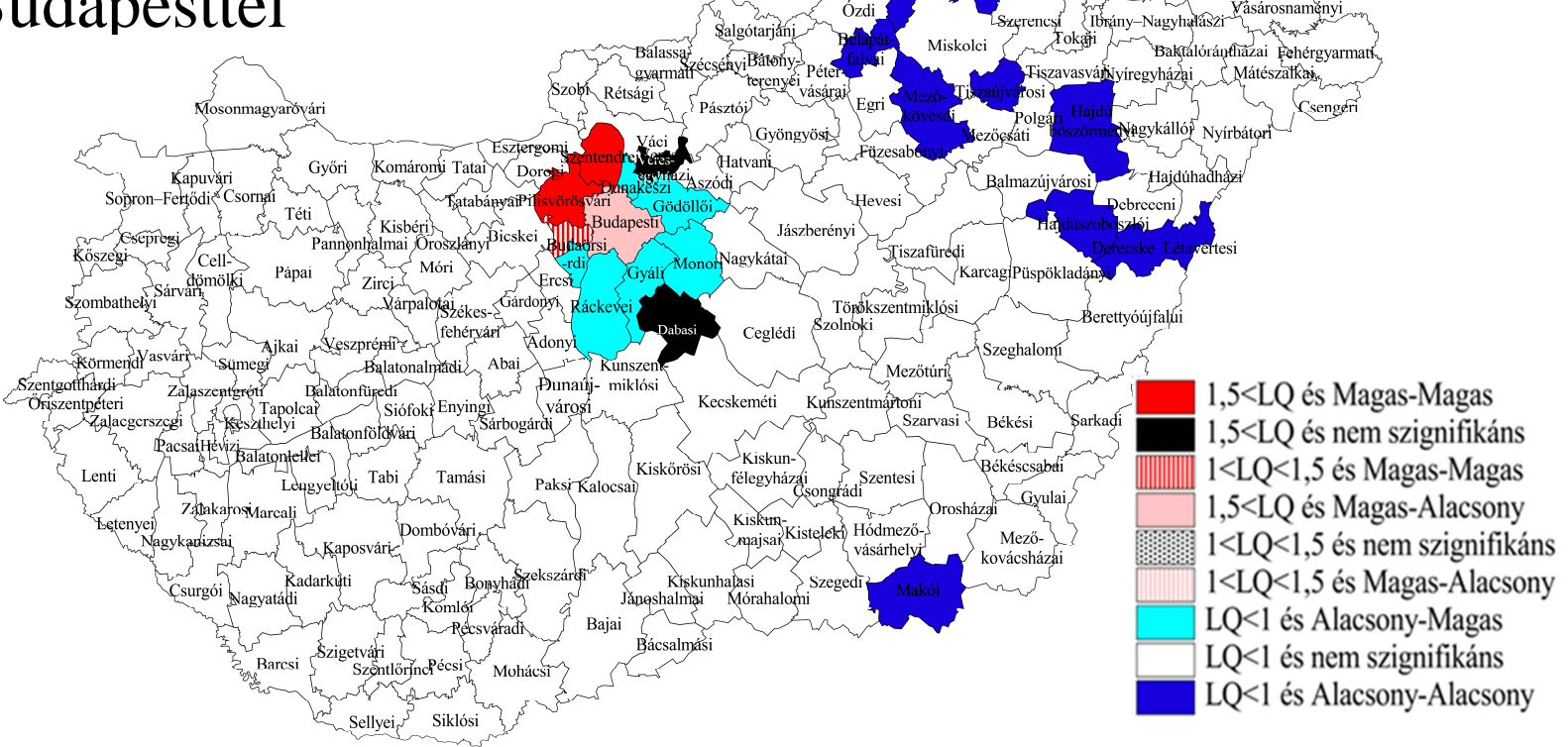

\begin{tabular}{|c|c|c|c|c|}
\hline \multirow{2}{*}{$\begin{array}{l}59 \text { Film, videó } \\
\text { gyártás, } \\
\text { televíziómüsor } \\
\text { gyártása, } \\
\text { hangfelvétel kiadás }\end{array}$} & \multicolumn{2}{|c|}{ Budapesttel } & \multicolumn{2}{|c|}{ Budapest nélkül } \\
\hline & $\begin{array}{c}\text { Iparban, } \\
\text { építőiparban } \\
\text { foglalkoztatottakhoz }\end{array}$ & $\begin{array}{c}\text { Nemzetgazdaság } \\
\text { egészében } \\
\text { foglalkoztatottakhoz }\end{array}$ & $\begin{array}{c}\text { Iparban, } \\
\text { építőiparban } \\
\text { foglalkoztatottakhoz }\end{array}$ & $\begin{array}{l}\text { Nemzetgazdaság } \\
\text { egészében } \\
\text { foglalkoztatottakhoz }\end{array}$ \\
\hline Átlagos méret (fö) & \multicolumn{2}{|c|}{3} & \multicolumn{2}{|c|}{2} \\
\hline Vállalkozások száma & \multicolumn{2}{|c|}{3691} & \multicolumn{2}{|c|}{1083} \\
\hline Moran index & 0,002 & 0,007 & 0,245 & 0,249 \\
\hline p érték & 0,068 & 0,024 & 0,001 & 0,000 \\
\hline EG $\gamma$ mutató & 0,310 & 0,360 & 0,013 & 0,014 \\
\hline $\begin{array}{c}\text { Normalizált } \\
\text { Herfindahl index }\end{array}$ & \multicolumn{2}{|c|}{0,005} & \multicolumn{2}{|c|}{0,010} \\
\hline
\end{tabular}

\section{Budapest nélkül}

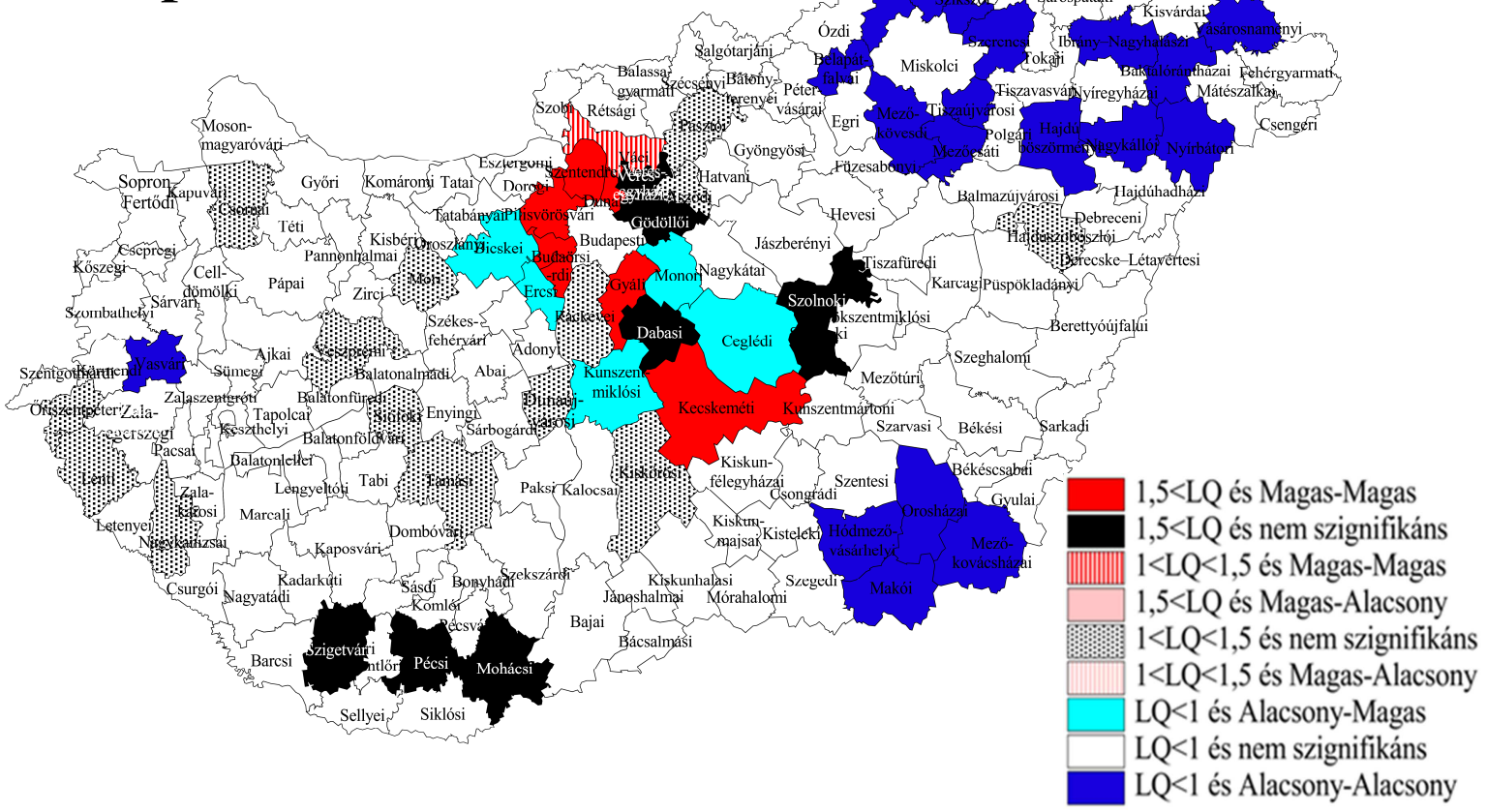




\section{II. melléklet 12. tábla:}

\section{Budapesttel}

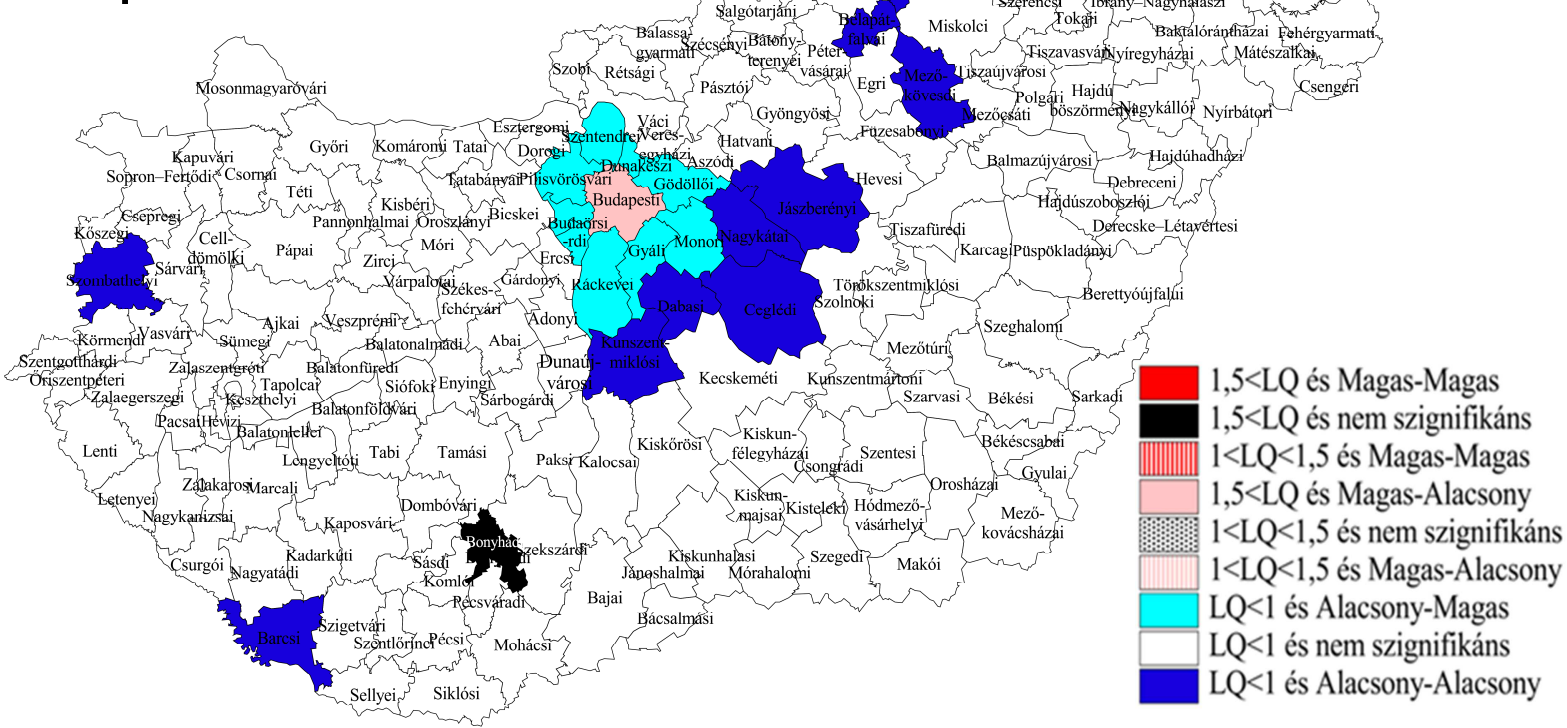

\begin{tabular}{|c|c|c|c|c|}
\hline \multirow[b]{2}{*}{\begin{tabular}{l}
\multicolumn{6}{c}{$\mathbf{6 0}$} \\
Músorösszeállítás, \\
músorszolgáltatás
\end{tabular}} & \multicolumn{2}{|c|}{ Budapesttel } & \multicolumn{2}{|c|}{ Budapest nélkül } \\
\hline & $\begin{array}{c}\text { Iparban, } \\
\text { építőiparban } \\
\text { foglalkoztatottakhoz }\end{array}$ & $\begin{array}{c}\text { Nemzetgazdaság } \\
\text { egészében } \\
\text { foglalkoztatottakhoz }\end{array}$ & $\begin{array}{c}\text { Iparban, } \\
\text { építőiparban } \\
\text { foglalkoztatottakhoz }\end{array}$ & $\begin{array}{c}\text { Nemzetgazdaság } \\
\text { egészében } \\
\text { foglalkoztatottakhoz }\end{array}$ \\
\hline Átlagos méret (fö) & \multicolumn{2}{|c|}{13} & \multicolumn{2}{|c|}{8} \\
\hline Vállalkozások száma & \multicolumn{2}{|c|}{855} & \multicolumn{2}{|c|}{1312} \\
\hline Moran index & $-0,028$ & $-0,022$ & 0,003 & $-0,022$ \\
\hline p érték & 0,002 & 0,002 & 0,370 & 0,389 \\
\hline EG $\gamma$ mutató & 0,386 & 0,450 & $-0,090$ & $-0,089$ \\
\hline $\begin{array}{c}\text { Normalizált } \\
\text { Herfindahl index }\end{array}$ & \multicolumn{2}{|c|}{0,092} & \multicolumn{2}{|c|}{0,093} \\
\hline
\end{tabular}

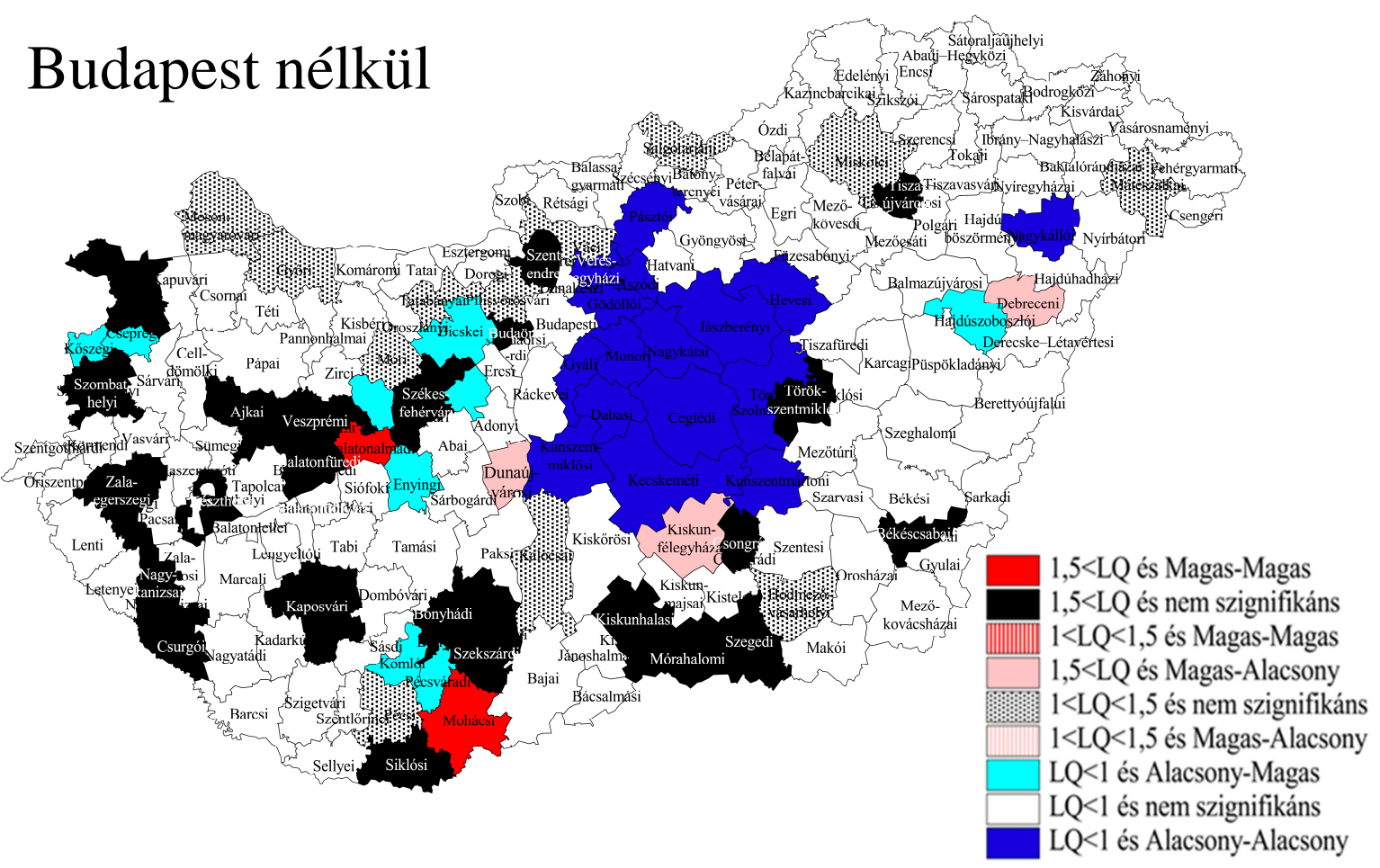




\section{II. melléklet 13. tábla:}

\section{Budapesttel}

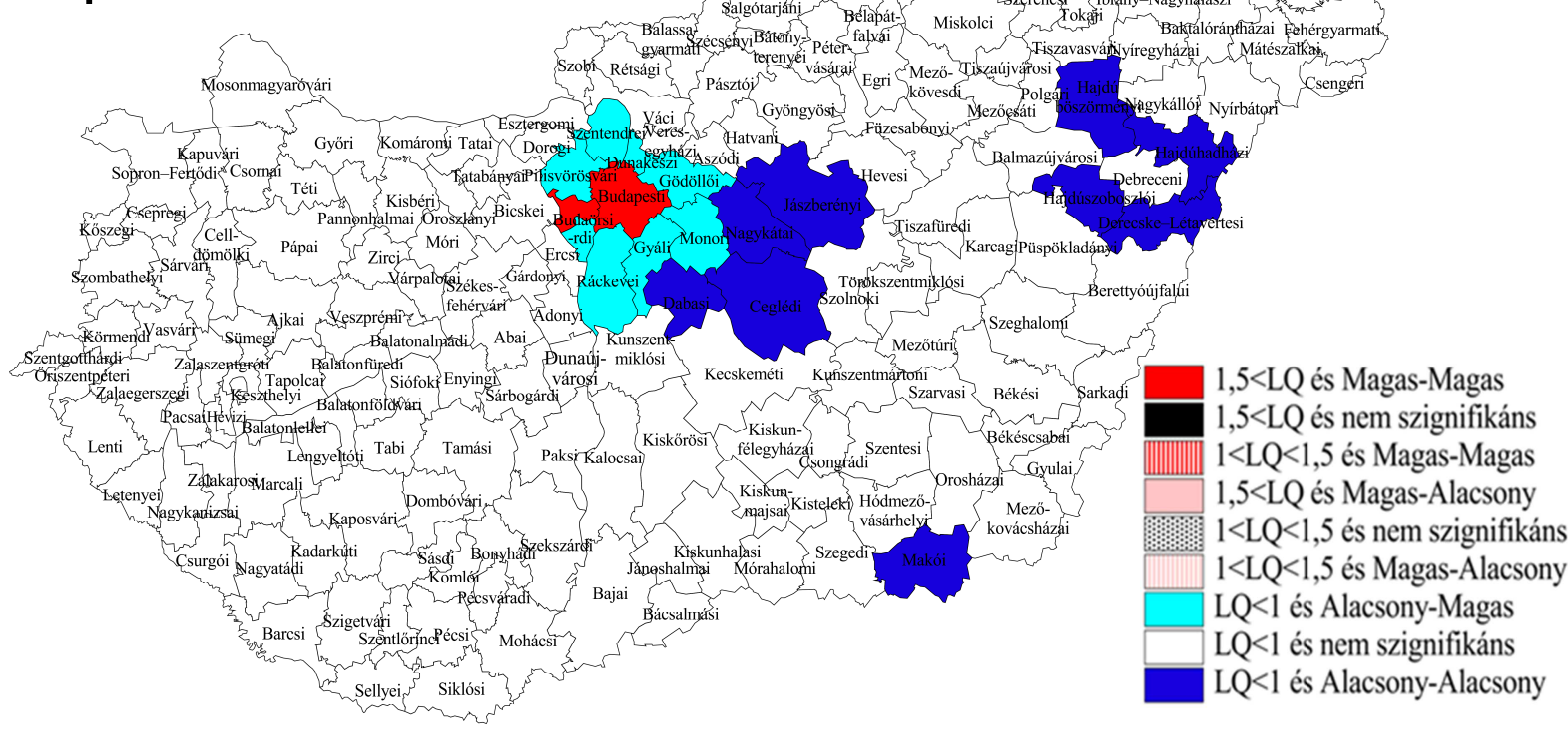

\begin{tabular}{|c|c|c|c|c|}
\hline \multirow{2}{*}{ 61 Távközlés } & \multicolumn{2}{|c|}{ Budapesttel } & \multicolumn{2}{c|}{ Budapest nélkül } \\
\cline { 2 - 5 } & $\begin{array}{c}\text { Iparban, } \\
\text { építőiparban } \\
\text { foglalkoztatottakhoz }\end{array}$ & $\begin{array}{c}\text { Nemzetgazdaság } \\
\text { egészében } \\
\text { foglalkoztatottakhoz }\end{array}$ & $\begin{array}{c}\text { Iparban, } \\
\text { építőiparban } \\
\text { foglalkoztatottakhoz }\end{array}$ & $\begin{array}{c}\text { Nemzetgazdaság } \\
\text { egészében } \\
\text { foglalkoztatottakhoz }\end{array}$ \\
\hline Átlagos méret (fö) & \multicolumn{2}{|c|}{27} & \multicolumn{2}{c|}{12} \\
\hline Vállalkozások száma & \multicolumn{2}{|c|}{1046} & $-0,011$ & $-0,008$ \\
\hline Moran index & 0,065 & 0,065 & 0,186 & 0,330 \\
\hline$p$ érték & 0,033 & 0,030 & 0,236 & 0,239 \\
\hline EG $\gamma$ mutató & 0,167 & 0,218 & \multicolumn{2}{c|}{0,132} \\
\hline $\begin{array}{c}\text { Normalizált } \\
\text { Herfindahl index }\end{array}$ & \multicolumn{2}{|c|}{0,126} & & \\
\hline
\end{tabular}

\section{Budapest nélkül}

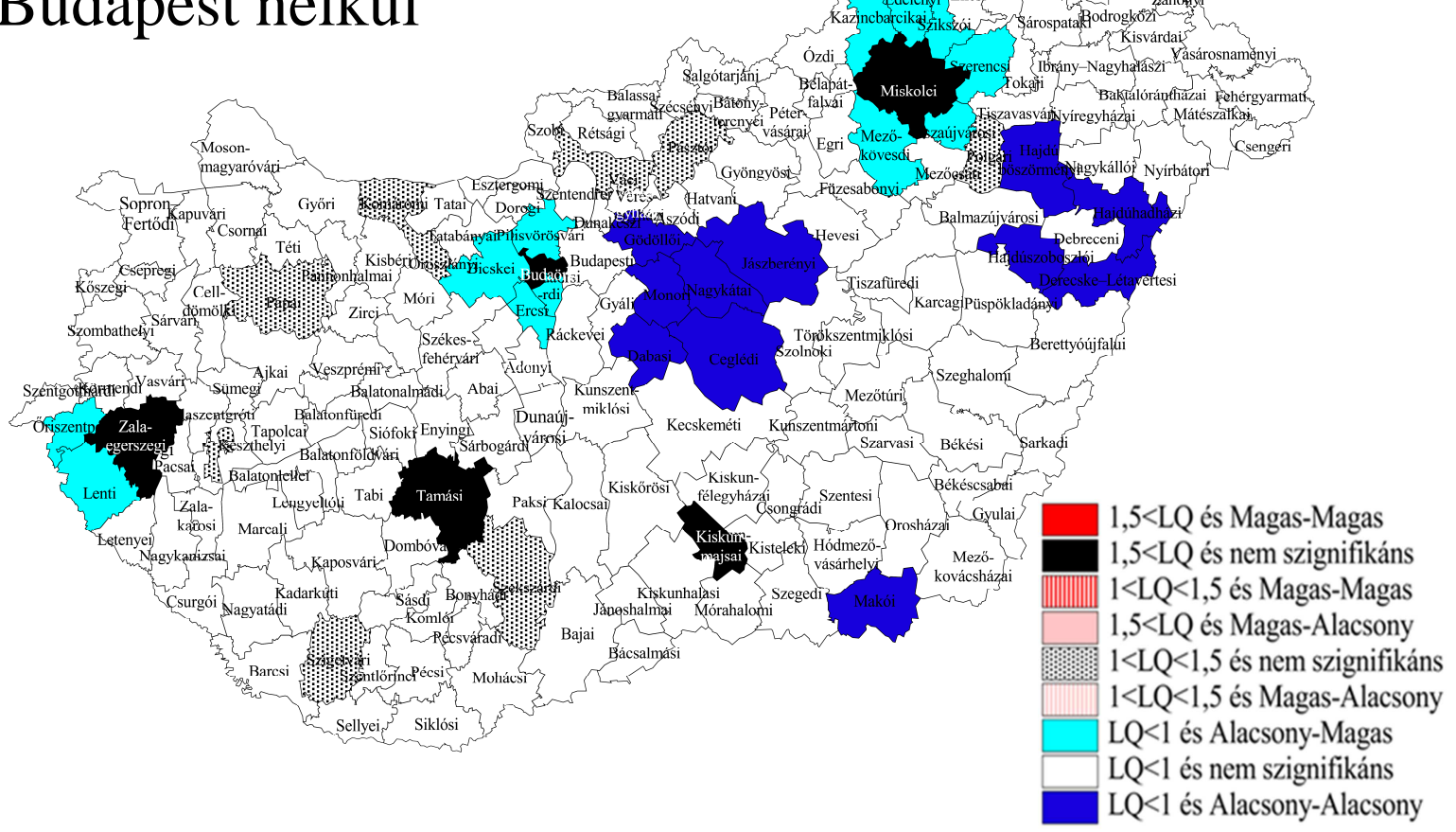


II. melléklet 14. tábla:

Budapesttel

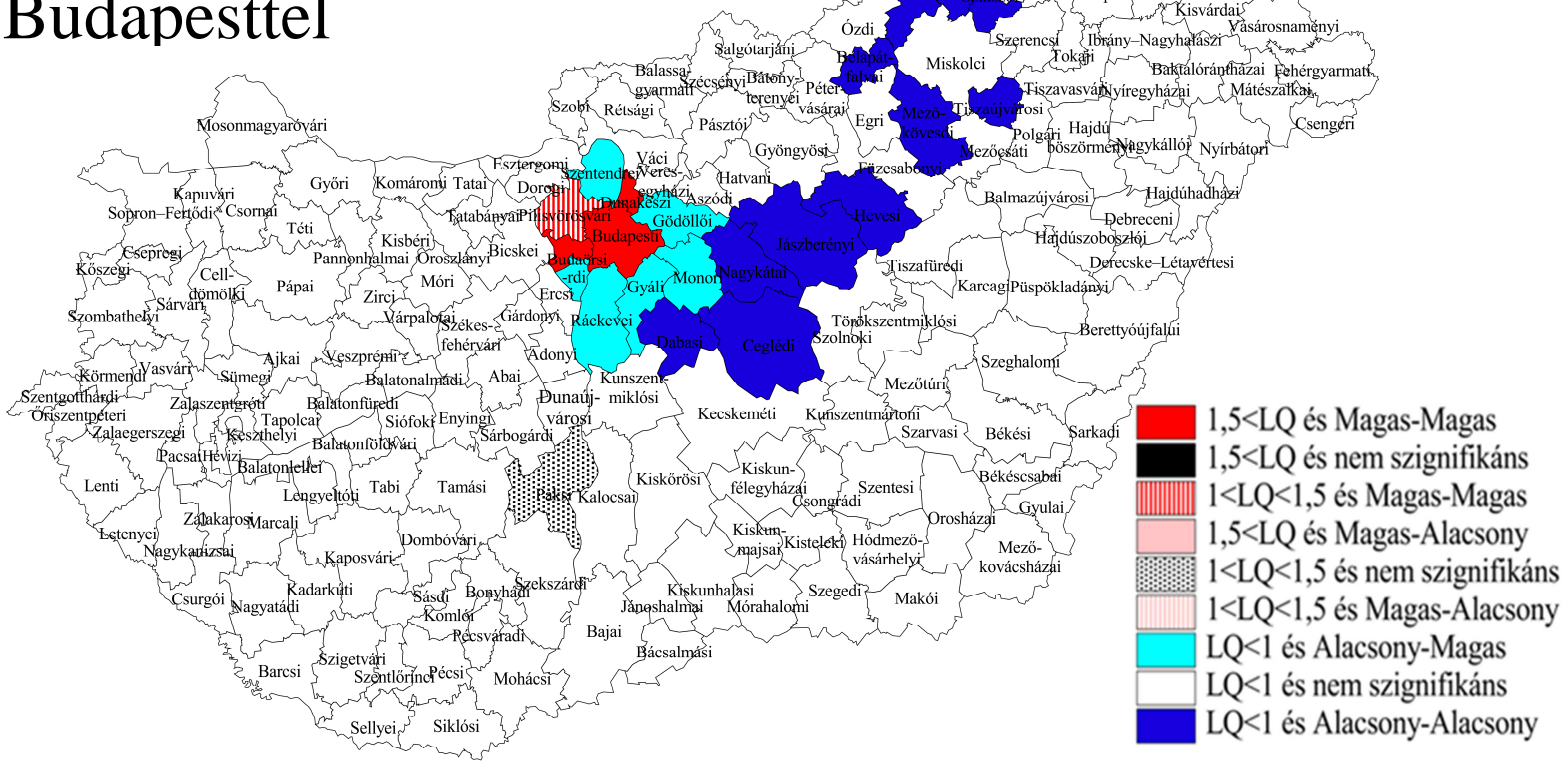

\begin{tabular}{|c|c|c|c|c|}
\hline \multirow[b]{2}{*}{$\begin{array}{l}62 \text { Információ- } \\
\text { technológiai } \\
\text { szolgáltatás }\end{array}$} & \multicolumn{2}{|c|}{ Budapesttel } & \multicolumn{2}{|c|}{ Budapest nélkül } \\
\hline & $\begin{array}{c}\text { Iparban, } \\
\text { építőiparban } \\
\text { foglalkoztatottakhoz }\end{array}$ & $\begin{array}{c}\text { Nemzetgazdaság } \\
\text { egészében } \\
\text { foglalkoztatottakhoz }\end{array}$ & $\begin{array}{c}\text { Iparban, } \\
\text { építőiparban } \\
\text { foglalkoztatottakhoz }\end{array}$ & $\begin{array}{l}\text { Nemzetgazdaság } \\
\text { egészében } \\
\text { foglalkoztatottakhoz }\end{array}$ \\
\hline Átlagos méret (fö) & \multicolumn{2}{|c|}{4} & \multicolumn{2}{|c|}{2} \\
\hline Vállalkozások száma & \multicolumn{2}{|c|}{15695} & \multicolumn{2}{|c|}{7270} \\
\hline Moran index & 0,008 & 0,012 & 0,198 & 0,194 \\
\hline p érték & 0,019 & 0,006 & 0,002 & 0,002 \\
\hline EG $\gamma$ mutató & 0,273 & 0,321 & 0,010 & 0,012 \\
\hline $\begin{array}{c}\text { Normalizált } \\
\text { Herfindahl index }\end{array}$ & \multicolumn{2}{|c|}{0,005} & \multicolumn{2}{|c|}{0,006} \\
\hline
\end{tabular}

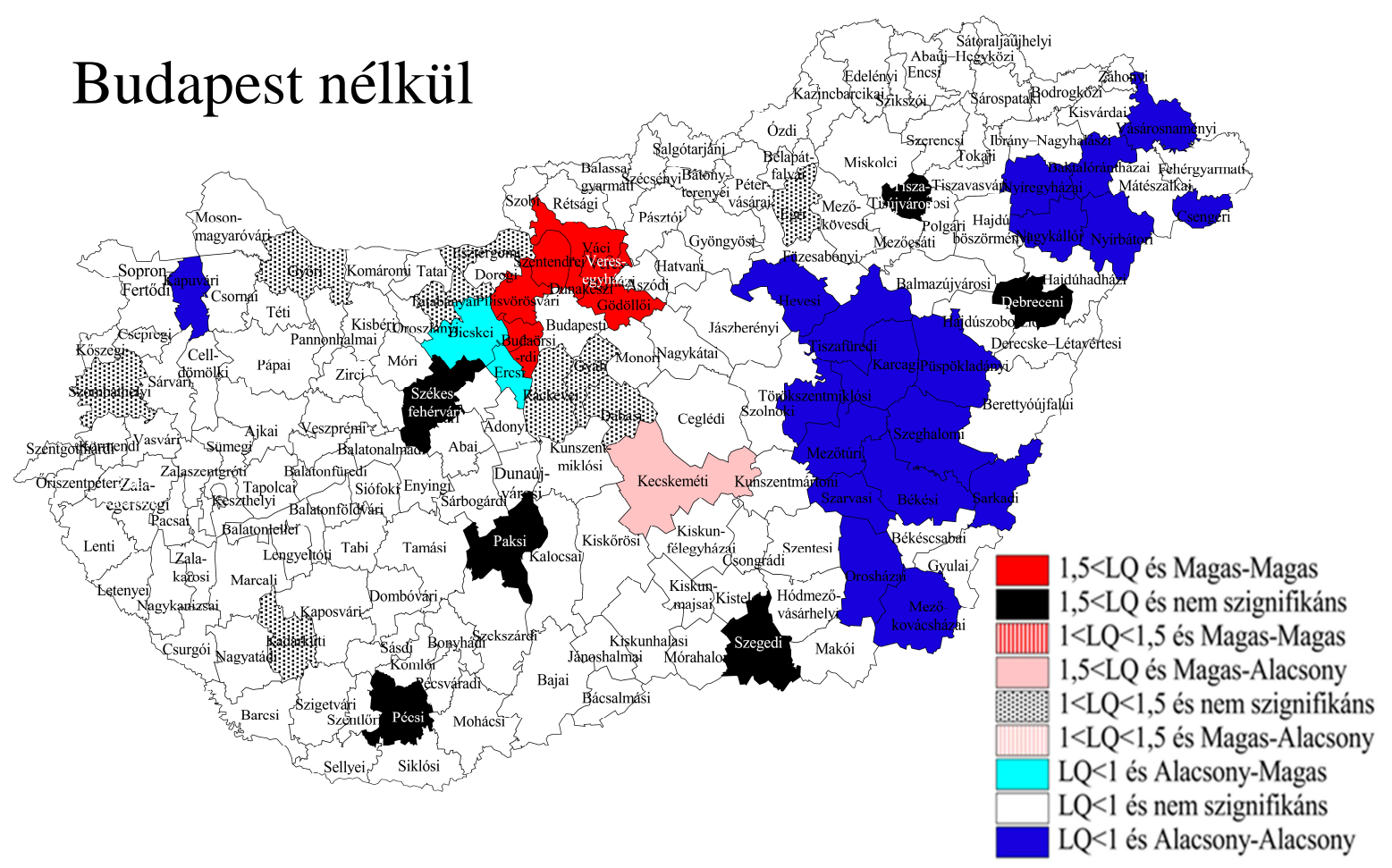




\section{II. melléklet 15. tábla:}

Budapesttel

\begin{tabular}{|c|c|c|c|c|}
\hline \multirow{2}{*}{$\begin{array}{c}\text { 63 Információs } \\
\text { szolgáltatás }\end{array}$} & $\begin{array}{c}\text { Iparban, } \\
\text { építöiparban } \\
\text { foglalkoztatottakhoz }\end{array}$ & $\begin{array}{c}\text { Nemzetgazdaság } \\
\text { egészében } \\
\text { foglalkoztatottakhoz }\end{array}$ & $\begin{array}{c}\text { Iparban, } \\
\text { építöiparban } \\
\text { foglalkoztatottakhoz }\end{array}$ & $\begin{array}{c}\text { Nemzetgazdaság } \\
\text { egészében } \\
\text { foglalkoztatottakhoz }\end{array}$ \\
\hline Átlagos méret (fó) & \multicolumn{2}{|c|}{4} & & 2 \\
\hline Vállalkozások száma & \multicolumn{2}{|c|}{4357} & 0,146 & 0,158 \\
\hline Moran index & $-0,010$ & $-0,005$ & 0,005 & 0,003 \\
\hline p érték & 0,170 & 0,451 & 0,006 & 0,007 \\
\hline EG $\gamma$ mutató & 0,326 & 0,378 & & 0,006 \\
\hline $\begin{array}{c}\text { Normalizált } \\
\text { Herfindahl index }\end{array}$ & \multicolumn{2}{|c|}{0,016} & & \\
\hline
\end{tabular}

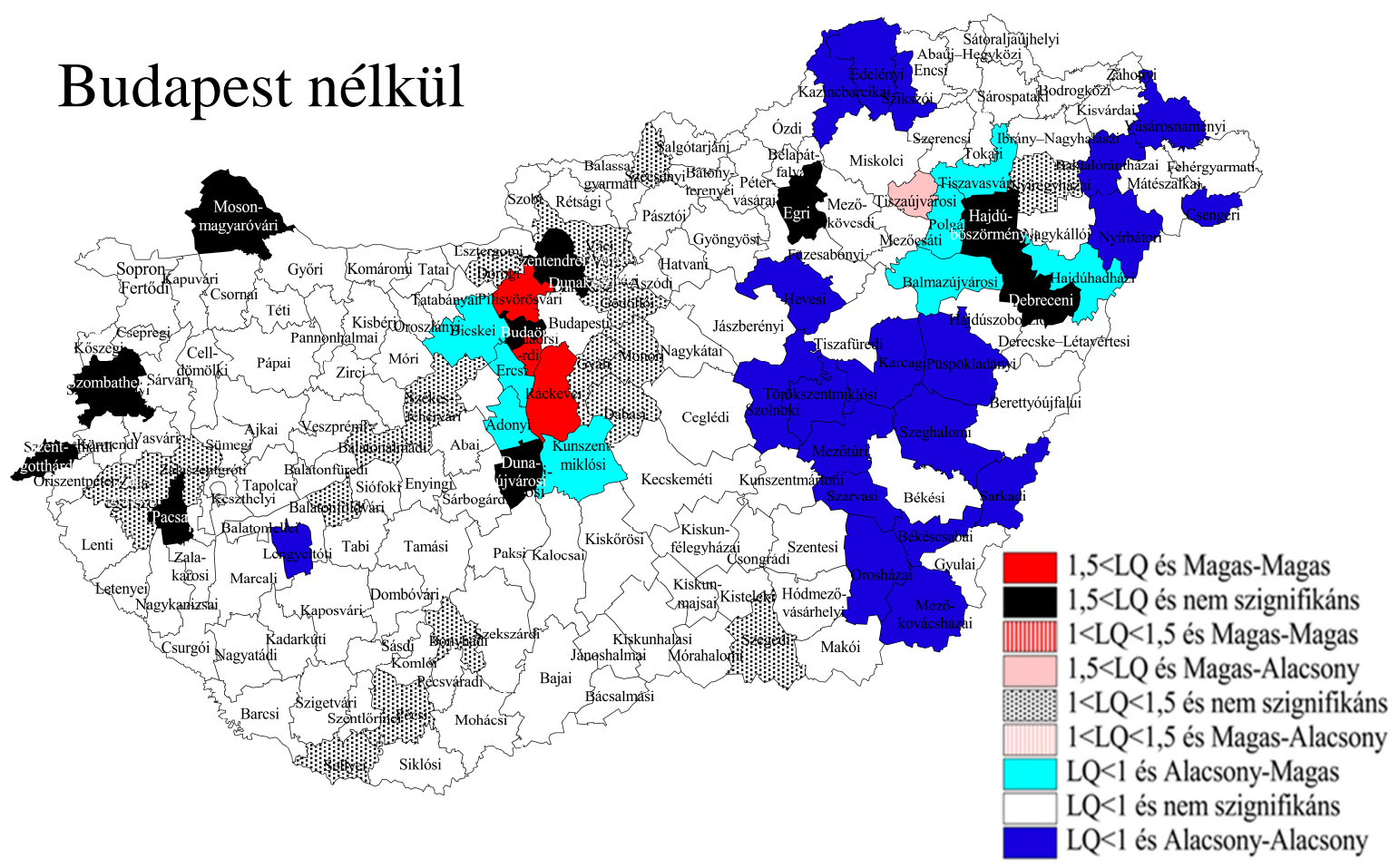


II. melléklet 16. tábla:

Budapesttel

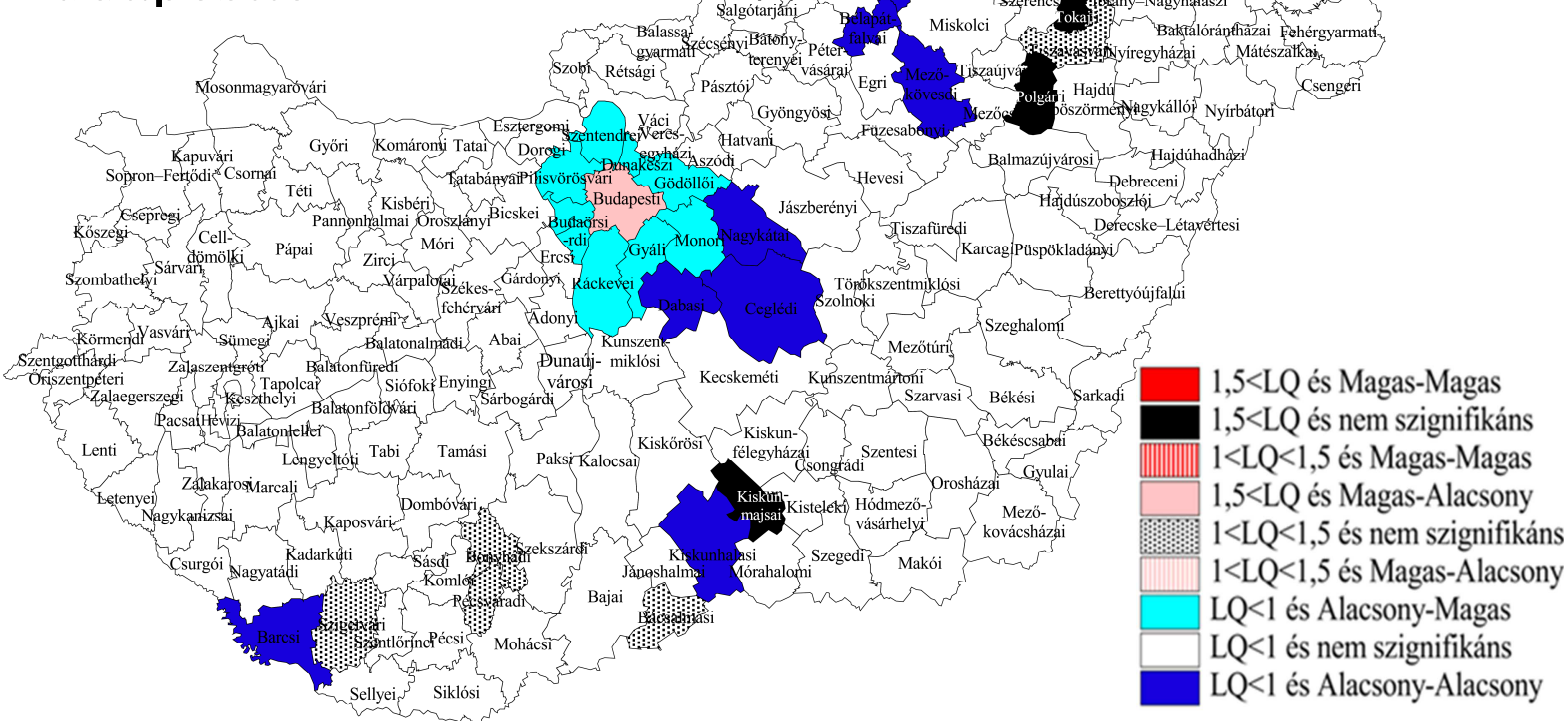

\begin{tabular}{|c|c|c|c|c|}
\hline \multirow{2}{*}{$\begin{array}{c}\text { 64 Pénzügyi } \\
\text { közvetítés, kivéve } \\
\text { biztosítási, } \\
\text { nyugdíjpénztári } \\
\text { tevékenység }\end{array}$} & \multicolumn{2}{|c|}{ Budapesttel } & \multicolumn{2}{|c|}{ Budapest nélkül } \\
\hline & $\begin{array}{c}\text { Iparban, } \\
\text { építőiparban } \\
\text { foglalkoztatottakhoz }\end{array}$ & $\begin{array}{c}\text { Nemzetgazdaság } \\
\text { egészében } \\
\text { foglalkoztatottakhoz }\end{array}$ & $\begin{array}{c}\text { Iparban, } \\
\text { építőiparban } \\
\text { foglalkoztatottakhoz }\end{array}$ & $\begin{array}{l}\text { Nemzetgazdaság } \\
\text { egészében } \\
\text { foglalkoztatottakhoz }\end{array}$ \\
\hline Átlagos méret (fö) & \multicolumn{2}{|c|}{62} & \multicolumn{2}{|c|}{24} \\
\hline Vállalkozások száma & \multicolumn{2}{|c|}{1989} & \multicolumn{2}{|c|}{851} \\
\hline Moran index & $-0,031$ & $-0,025$ & $-0,007$ & $-0,022$ \\
\hline p érték & 0,002 & 0,003 & 0,494 & 0,363 \\
\hline EG $\gamma$ mutató & 0,349 & 0,405 & 0,000 & 0,000 \\
\hline $\begin{array}{c}\text { Normalizált } \\
\text { Herfindahl index }\end{array}$ & \multicolumn{2}{|c|}{0,042} & \multicolumn{2}{|c|}{0,006} \\
\hline
\end{tabular}

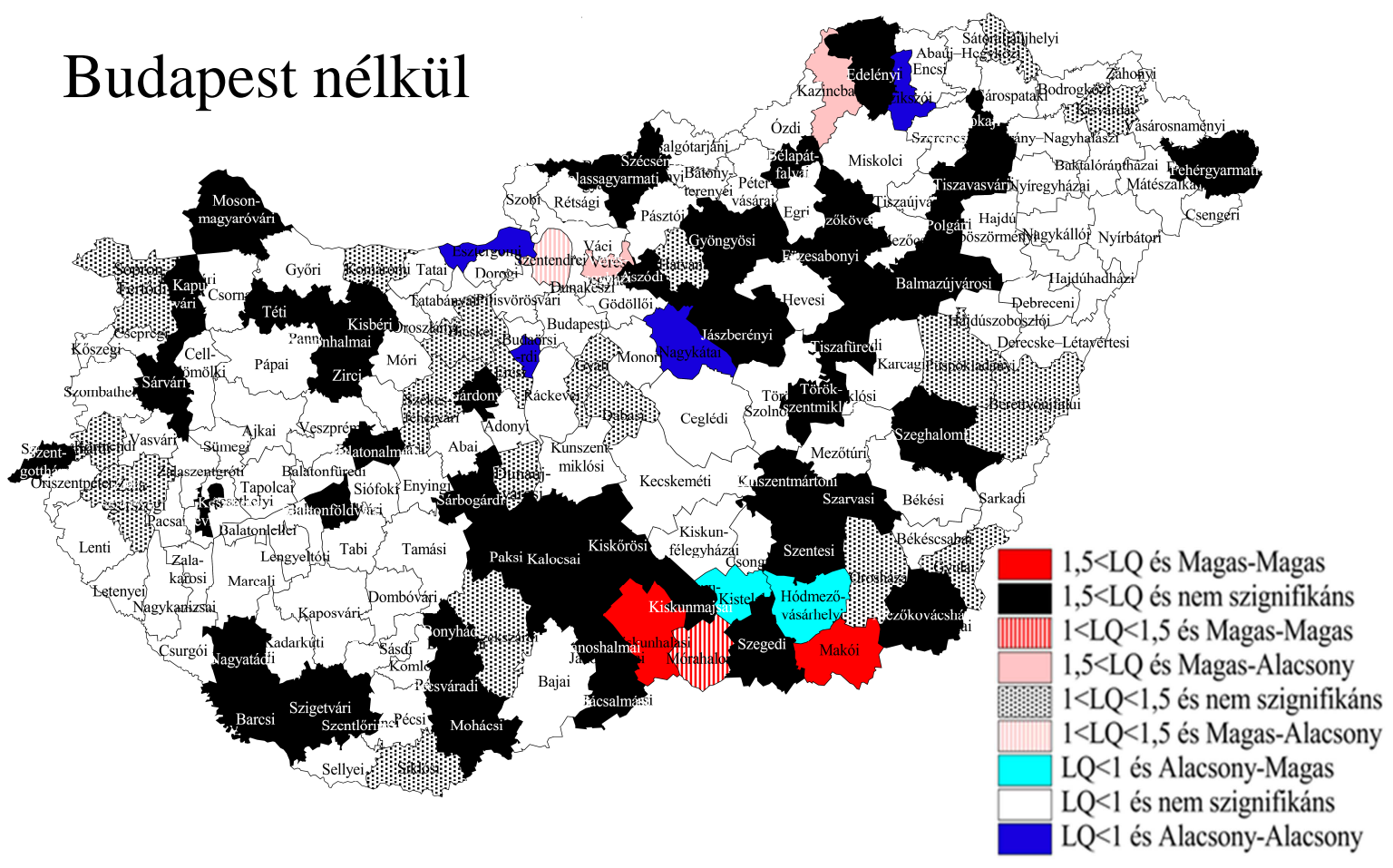


II. melléklet 17. tábla:

Budapesttel

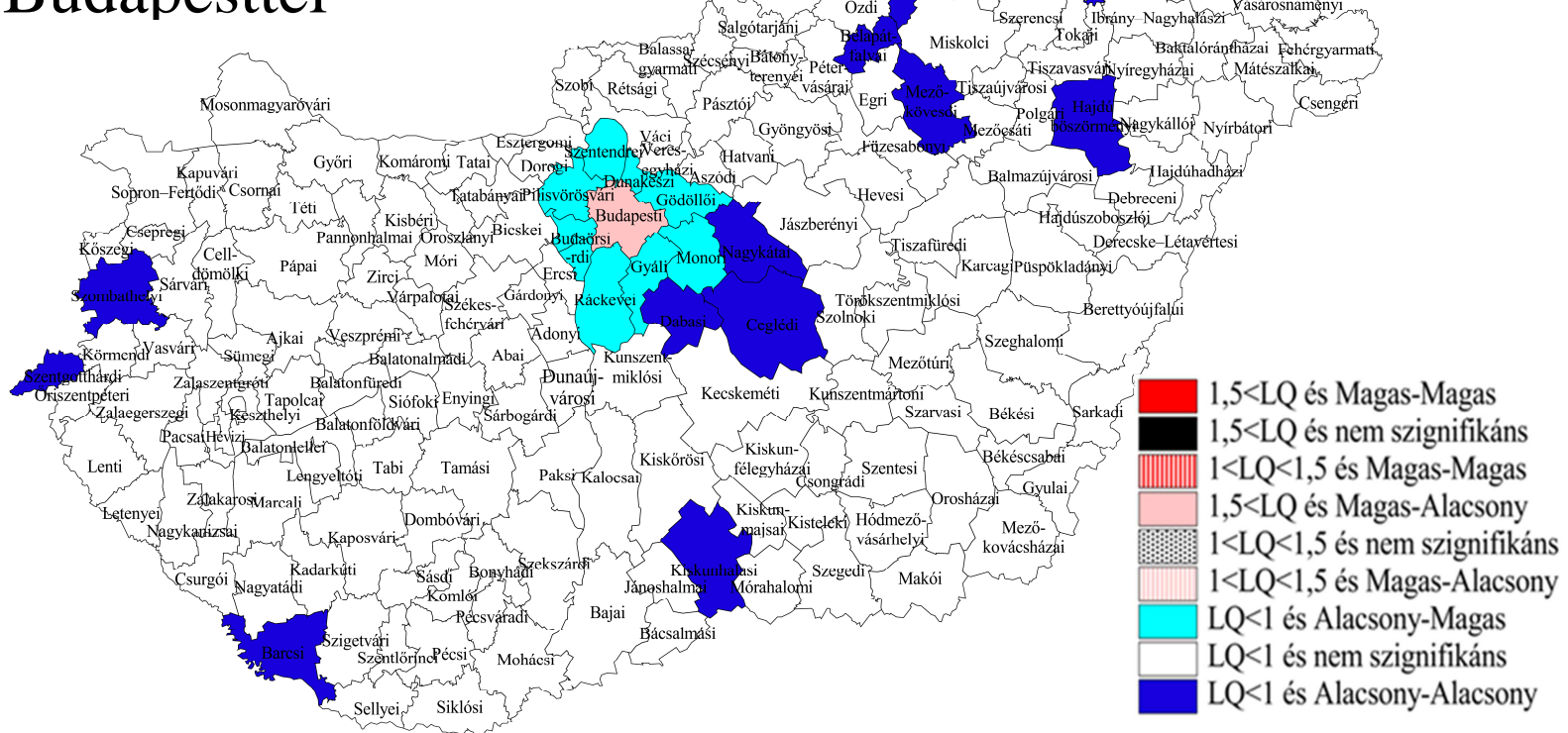

\begin{tabular}{|c|c|c|c|c|}
\hline \multirow{2}{*}{$\begin{array}{c}\text { 65 Biztosítás, } \\
\text { viszontbiztosítás, } \\
\text { nyugdíjalapok } \\
\text { (kivéve: kötelező } \\
\text { társadalombiztosítás) }\end{array}$} & \multicolumn{2}{|c|}{ Budapesttel } & \multicolumn{2}{|c|}{ Budapest nélkül } \\
\hline & $\begin{array}{c}\text { Iparban, } \\
\text { építőiparban } \\
\text { foglalkoztatottakhoz }\end{array}$ & $\begin{array}{c}\text { Nemzetgazdaság } \\
\text { egészében } \\
\text { foglalkoztatottakhoz }\end{array}$ & $\begin{array}{c}\text { Iparban, } \\
\text { építőiparban } \\
\text { foglalkoztatottakhoz }\end{array}$ & $\begin{array}{c}\text { Nemzetgazdaság } \\
\text { egészében } \\
\text { foglalkoztatottakhoz }\end{array}$ \\
\hline Átlagos méret (fö) & \multicolumn{2}{|c|}{210} & \multicolumn{2}{|c|}{3} \\
\hline Vállalkozások száma & \multicolumn{2}{|c|}{106} & \multicolumn{2}{|c|}{48} \\
\hline Moran index & $-0,027$ & $-0,023$ & $-0,008$ & 0,009 \\
\hline p érték & 0,002 & 0,003 & 0,472 & 0,470 \\
\hline EG $\gamma$ mutató & 0,565 & 0,647 & $-0,031$ & $-0,023$ \\
\hline $\begin{array}{l}\text { Normalizált Herfindahl } \\
\text { index }\end{array}$ & \multicolumn{2}{|c|}{0,177} & \multicolumn{2}{|c|}{0,294} \\
\hline
\end{tabular}

\section{Budapest nélkül}

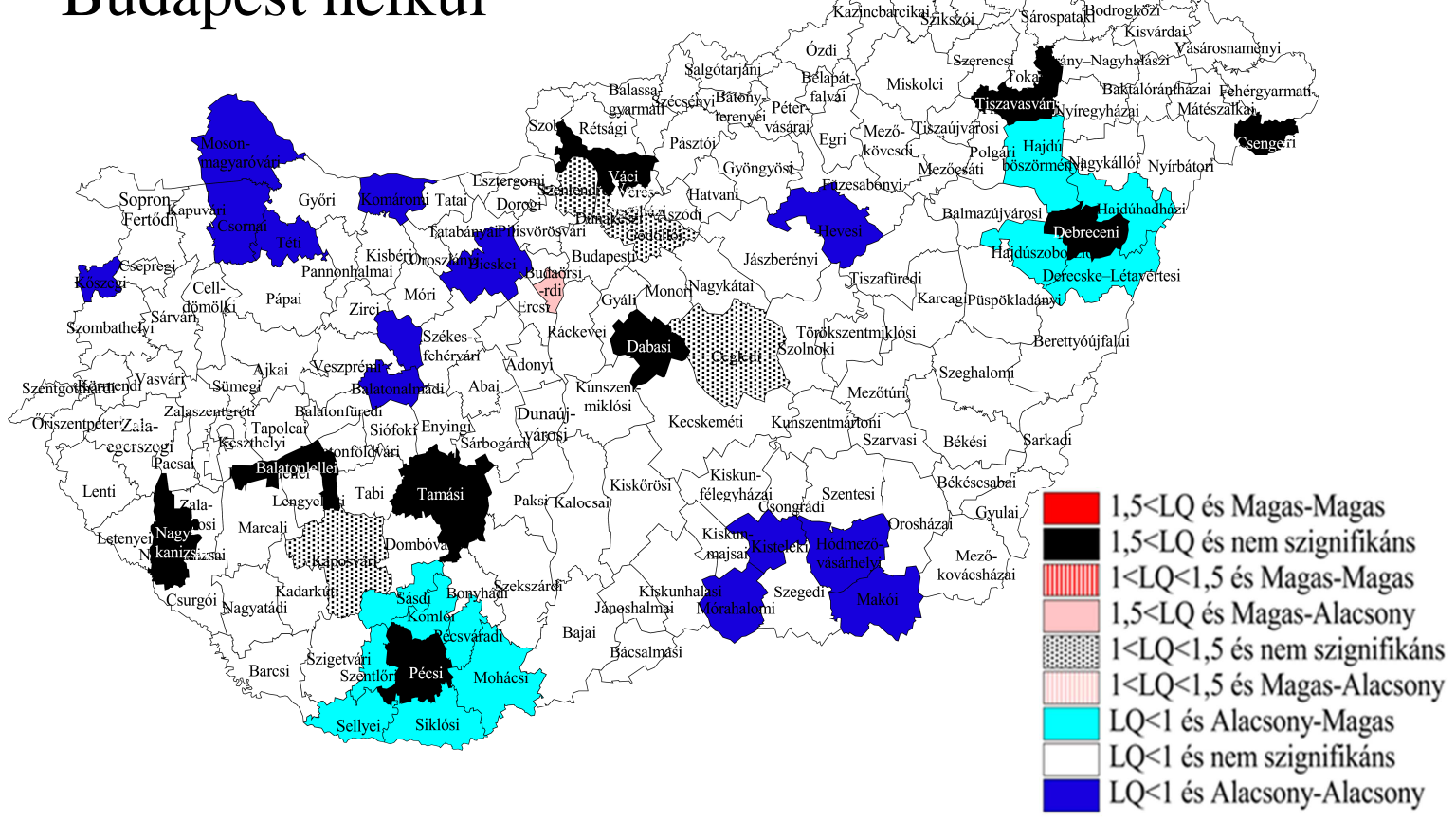




\section{II. melléklet 18. tábla:}

Budapesttel

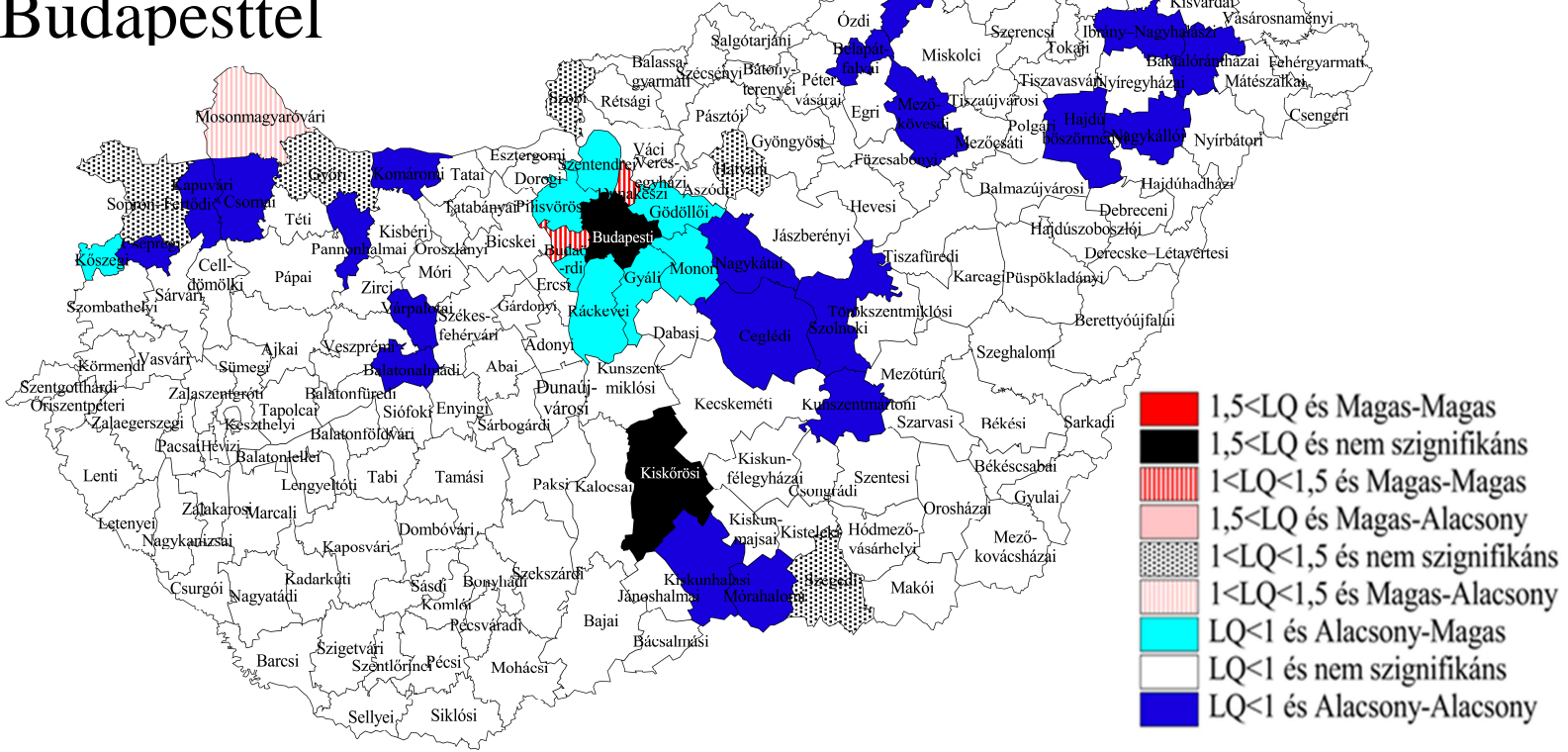

\begin{tabular}{|c|c|c|c|c|}
\hline \multirow[b]{2}{*}{$\begin{array}{l}66 \text { Egyéb pénzügyi } \\
\text { tevékenység }\end{array}$} & \multicolumn{2}{|c|}{ Budapesttel } & \multicolumn{2}{|c|}{ Budapest nélkül } \\
\hline & $\begin{array}{c}\text { Iparban, } \\
\text { építőiparban } \\
\text { foglalkoztatottakhoz }\end{array}$ & $\begin{array}{c}\text { Nemzetgazdaság } \\
\text { egészében } \\
\text { foglalkoztatottakhoz }\end{array}$ & $\begin{array}{c}\text { Iparban, } \\
\text { építőiparban } \\
\text { foglalkoztatottakhoz }\end{array}$ & $\begin{array}{c}\text { Nemzetgazdaság } \\
\text { egészében } \\
\text { foglalkoztatottakhoz }\end{array}$ \\
\hline Átlagos méret (fö) & \multicolumn{2}{|c|}{3} & \multicolumn{2}{|c|}{2} \\
\hline Vállalkozások száma & \multicolumn{2}{|c|}{8496} & \multicolumn{2}{|c|}{5485} \\
\hline Moran index & $-0,008$ & 0,000 & 0,035 & 0,006 \\
\hline p érték & 0,327 & 0,082 & 0,173 & 0,362 \\
\hline EG $\gamma$ mutató & 0,132 & 0,168 & 0,003 & 0,005 \\
\hline $\begin{array}{c}\text { Normalizált } \\
\text { Herfindahl index }\end{array}$ & \multicolumn{2}{|c|}{0,004} & \multicolumn{2}{|c|}{0,001} \\
\hline
\end{tabular}

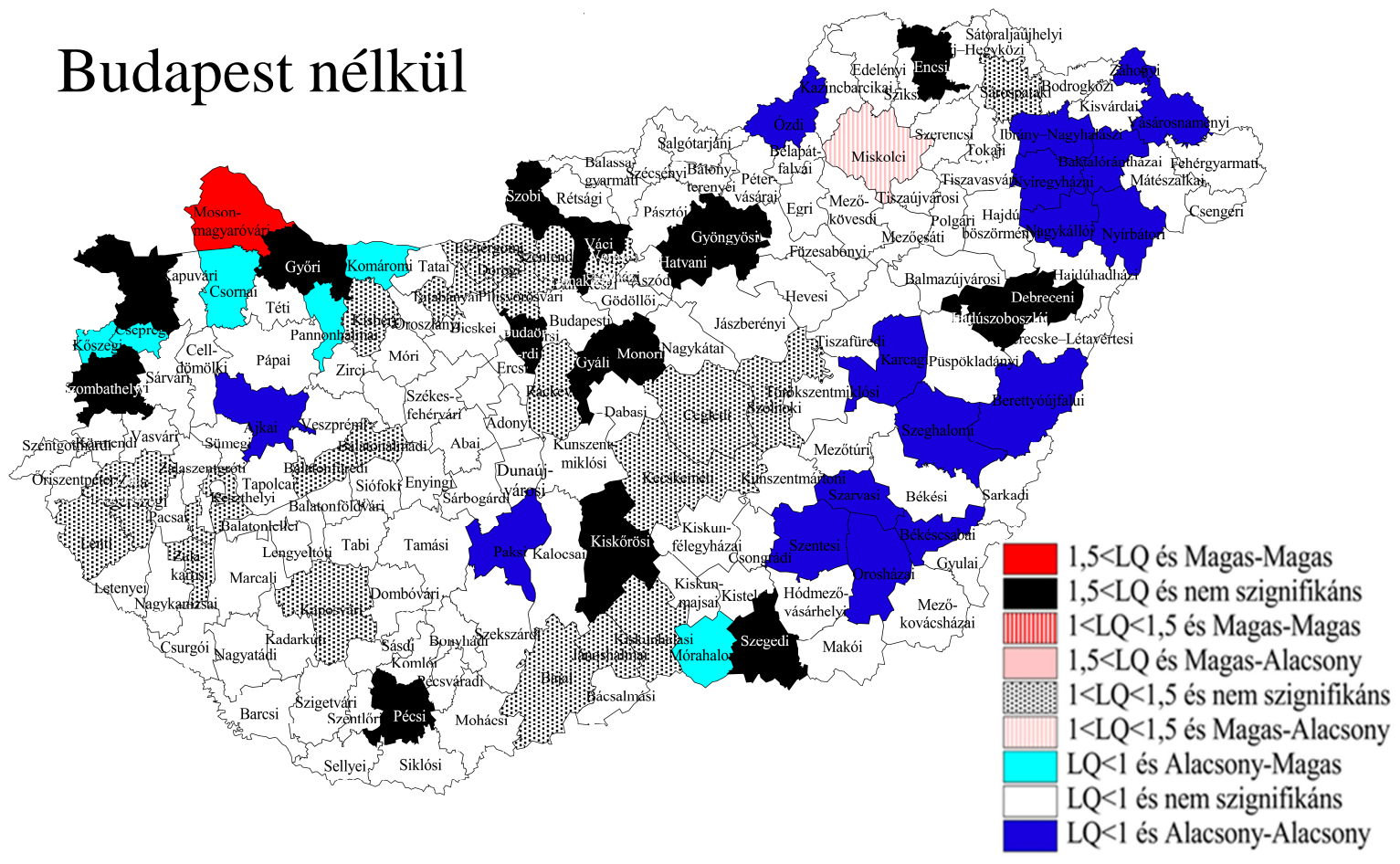


II. melléklet 19. tábla:

Budapesttel

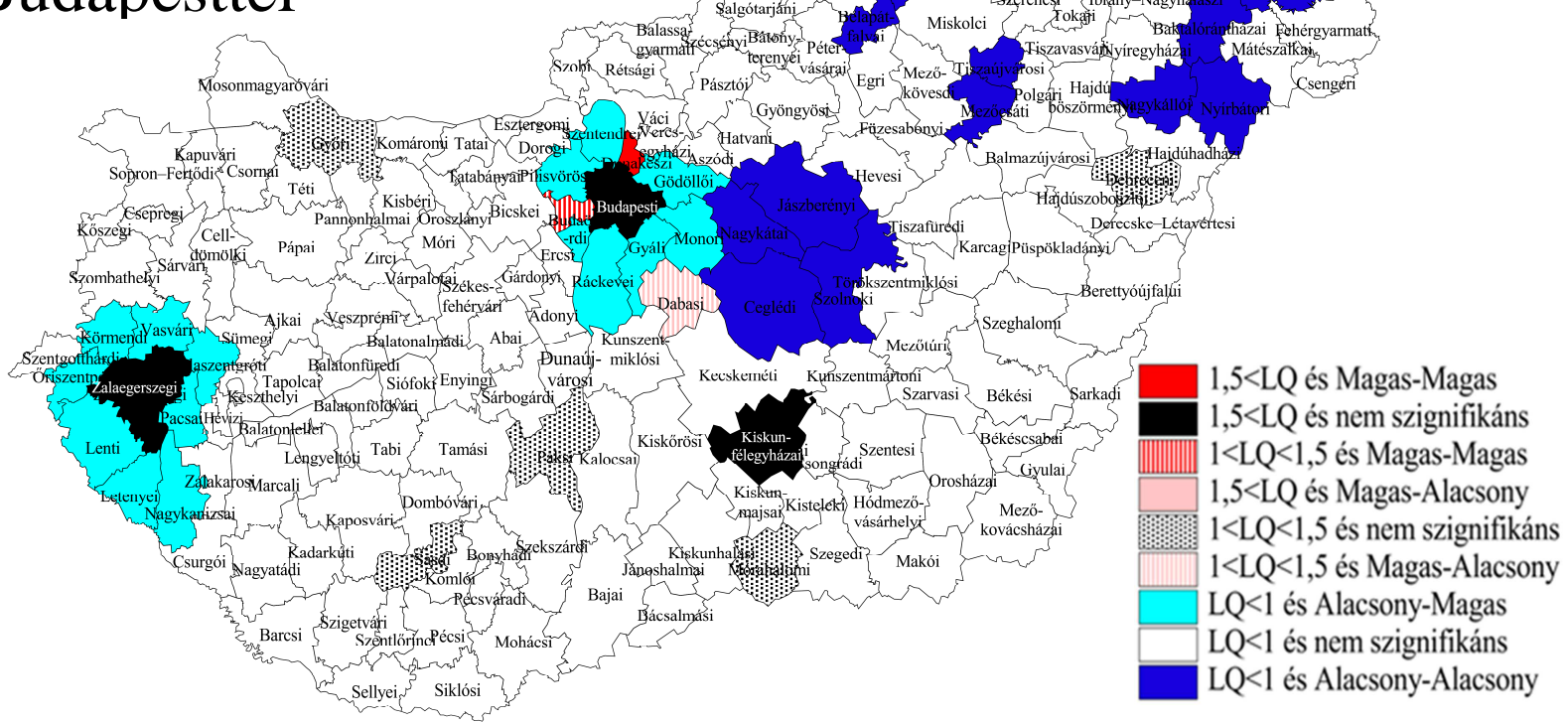

\begin{tabular}{|c|c|c|c|c|}
\hline \multirow[b]{2}{*}{$\begin{array}{l}\text { 69 Jogi, számviteli, } \\
\text { adószakértői } \\
\text { tevékenység }\end{array}$} & \multicolumn{2}{|c|}{ Budapesttel } & \multicolumn{2}{|c|}{ Budapest nélkül } \\
\hline & $\begin{array}{c}\text { Iparban, } \\
\text { építőiparban } \\
\text { foglalkoztatottakhoz }\end{array}$ & $\begin{array}{c}\text { Nemzetgazdaság } \\
\text { egészében } \\
\text { foglalkoztatottakhoz }\end{array}$ & $\begin{array}{c}\text { Iparban, } \\
\text { építőiparban } \\
\text { foglalkoztatottakhoz }\end{array}$ & $\begin{array}{l}\text { Nemzetgazdaság } \\
\text { egészében } \\
\text { foglalkoztatottakhoz }\end{array}$ \\
\hline Átlagos méret (fö) & \multicolumn{2}{|c|}{3} & \multicolumn{2}{|c|}{3} \\
\hline Vállalkozások száma & \multicolumn{2}{|c|}{22325} & \multicolumn{2}{|c|}{12103} \\
\hline Moran index & $-0,005$ & 0,003 & $-0,010$ & $-0,035$ \\
\hline p érték & 0,419 & 0,065 & 0,480 & 0,274 \\
\hline EG $\gamma$ mutató & 0,088 & 0,117 & 0,002 & 0,004 \\
\hline $\begin{array}{c}\text { Normalizált } \\
\text { Herfindahl index }\end{array}$ & \multicolumn{2}{|c|}{0,002} & \multicolumn{2}{|c|}{0,002} \\
\hline
\end{tabular}

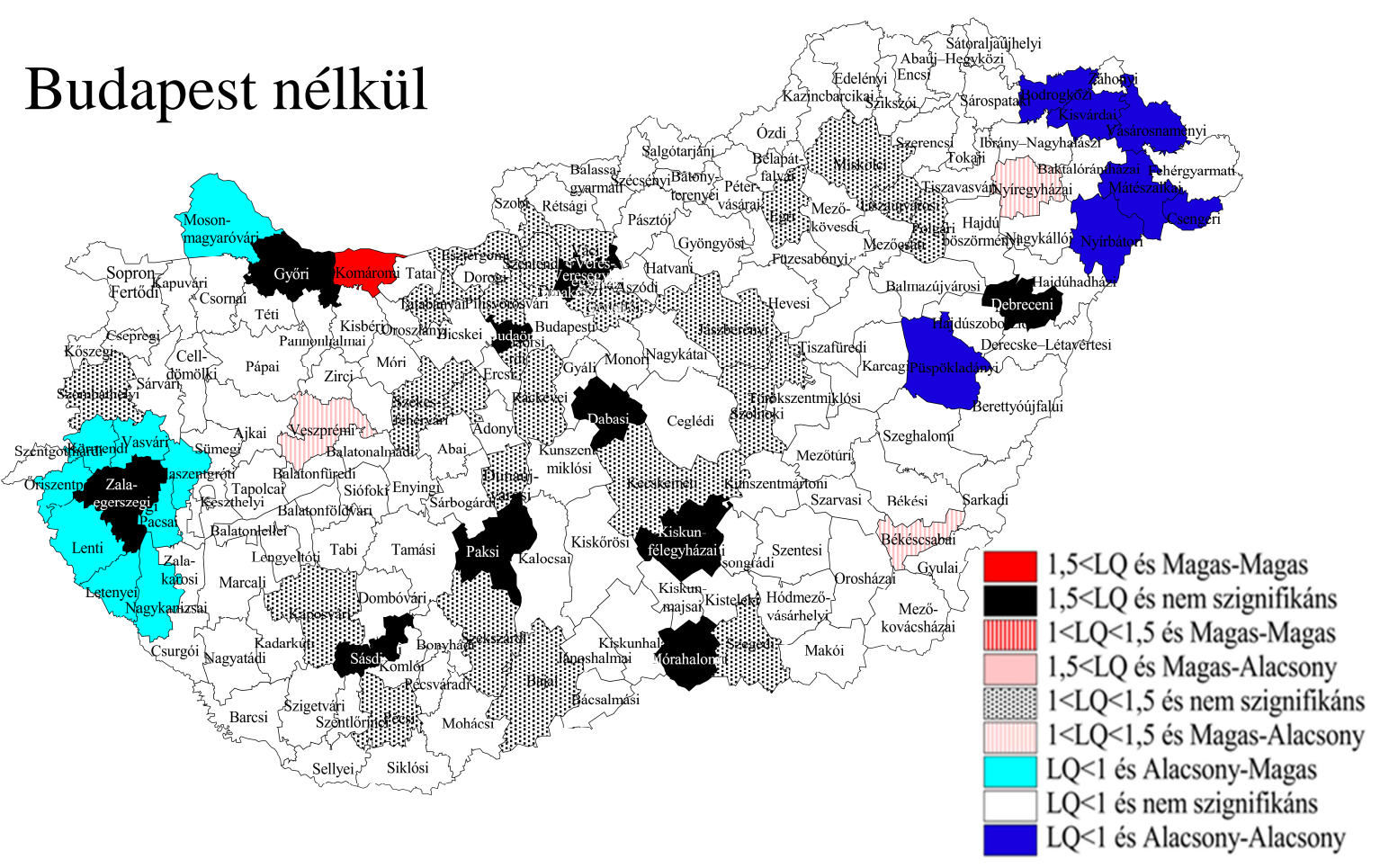


II. melléklet 20. tábla:

Budapesttel

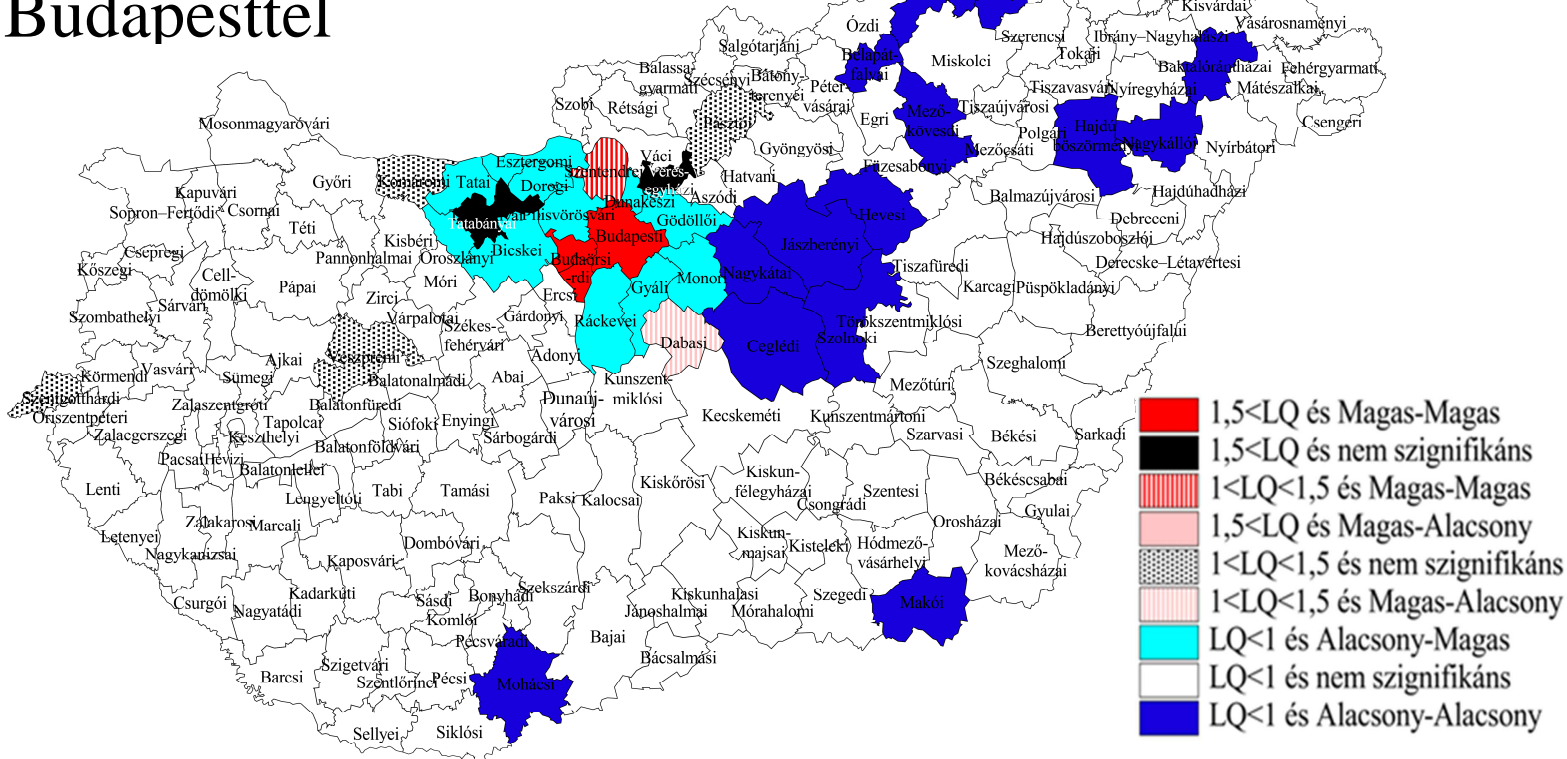

\begin{tabular}{|c|c|c|c|c|}
\hline \multirow[b]{2}{*}{$\begin{array}{l}70 \text { Üzletvezetési, } \\
\text { vezetói tanácsadás }\end{array}$} & \multicolumn{2}{|c|}{ Budapesttel } & \multicolumn{2}{|c|}{ Budapest nélkül } \\
\hline & $\begin{array}{c}\text { Iparban, } \\
\text { építőiparban } \\
\text { foglalkoztatottakhoz }\end{array}$ & $\begin{array}{c}\text { Nemzetgazdaság } \\
\text { egészében } \\
\text { foglalkoztatottakhoz }\end{array}$ & $\begin{array}{c}\text { Iparban, } \\
\text { építőiparban } \\
\text { foglalkoztatottakhoz }\end{array}$ & $\begin{array}{l}\text { Nemzetgazdaság } \\
\text { egészében } \\
\text { foglalkoztatottakhoz }\end{array}$ \\
\hline Átlagos méret (fö) & \multicolumn{2}{|c|}{3} & \multicolumn{2}{|c|}{2} \\
\hline Vállalkozások száma & \multicolumn{2}{|c|}{20464} & \multicolumn{2}{|c|}{8798} \\
\hline Moran index & 0,012 & 0,016 & 0,152 & 0,142 \\
\hline p érték & 0,031 & 0,014 & 0,005 & 0,006 \\
\hline EG $\gamma$ mutató & 0,184 & 0,225 & 0,008 & 0,009 \\
\hline $\begin{array}{c}\text { Normalizált } \\
\text { Herfindahl index }\end{array}$ & \multicolumn{2}{|c|}{0,002} & \multicolumn{2}{|c|}{0,007} \\
\hline
\end{tabular}

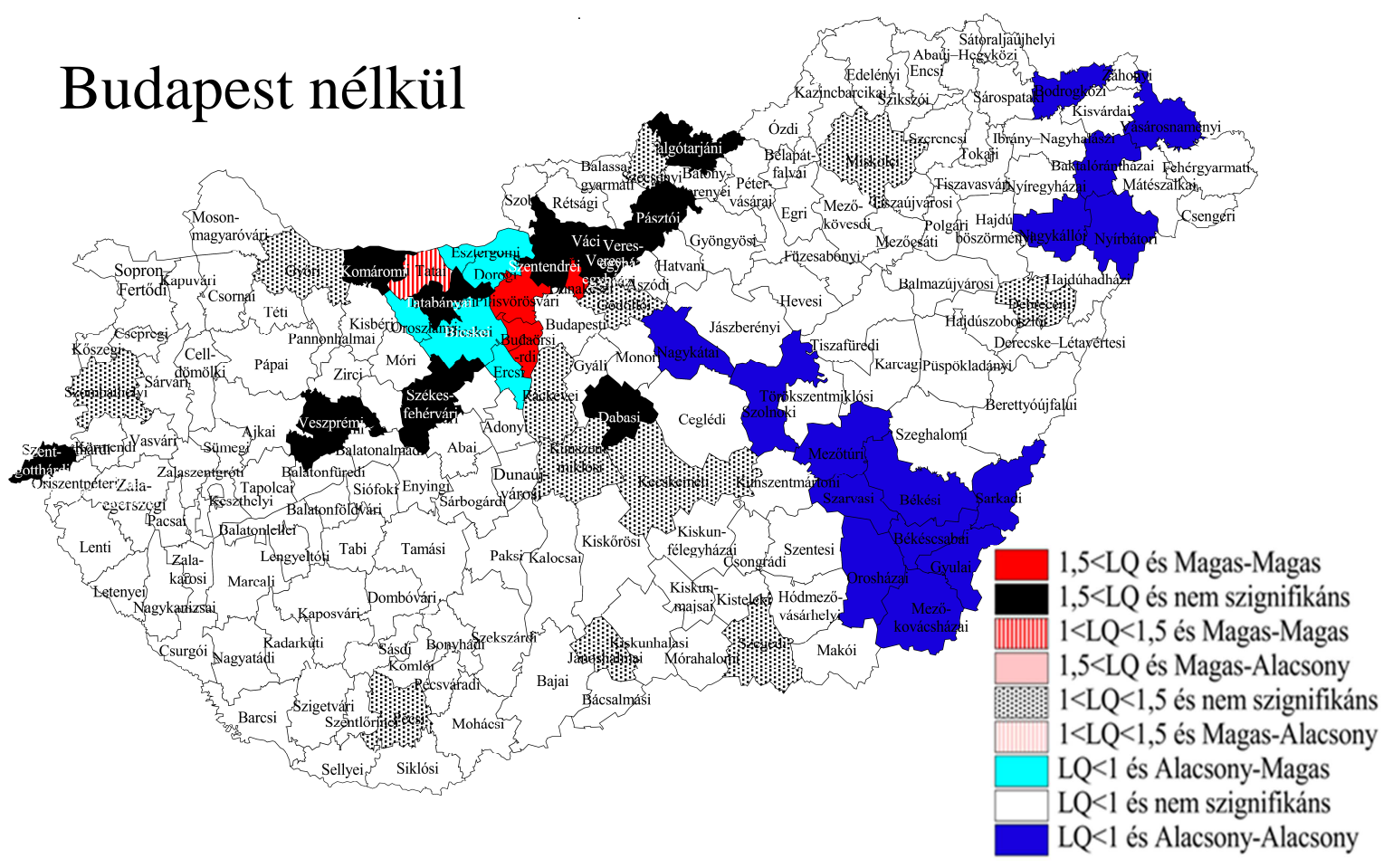


II. melléklet 21. tábla:

Budapesttel

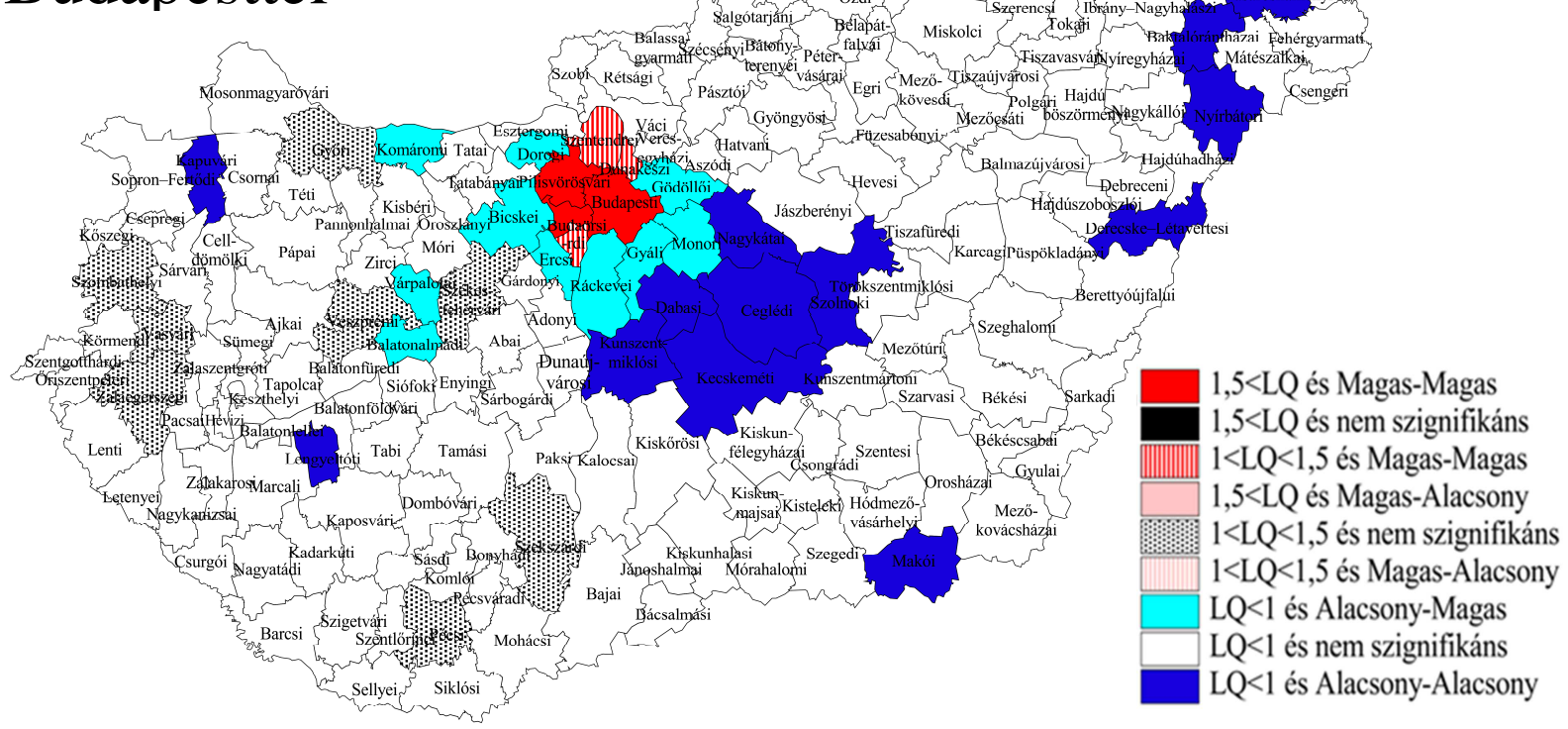

\begin{tabular}{|c|c|c|c|c|}
\hline \multirow{2}{*}{$\begin{array}{l}71 \text { Építészmérnöki } \\
\text { tevékenység; } \\
\text { müszaki vizsgálat, } \\
\text { elemzés }\end{array}$} & \multicolumn{2}{|c|}{ Budapesttel } & \multicolumn{2}{|c|}{ Budapest nélkül } \\
\hline & $\begin{array}{c}\text { Iparban, } \\
\text { építőiparban } \\
\text { foglalkoztatottakhoz }\end{array}$ & $\begin{array}{c}\text { Nemzetgazdaság } \\
\text { egészében } \\
\text { foglalkoztatottakhoz }\end{array}$ & $\begin{array}{c}\text { Iparban, } \\
\text { építőiparban } \\
\text { foglalkoztatottakhoz }\end{array}$ & $\begin{array}{c}\text { Nemzetgazdaság } \\
\text { egészében } \\
\text { foglalkoztatottakhoz }\end{array}$ \\
\hline Átlagos méret (fö) & \multicolumn{2}{|c|}{3} & \multicolumn{2}{|c|}{3} \\
\hline Vállalkozások száma & \multicolumn{2}{|c|}{19300} & \multicolumn{2}{|c|}{11388} \\
\hline Moran index & 0,010 & 0,016 & 0,070 & 0,034 \\
\hline p érték & 0,007 & 0,001 & 0,060 & 0,191 \\
\hline EG $\gamma$ mutató & 0,098 & 0,129 & 0,004 & 0,006 \\
\hline $\begin{array}{c}\text { Normalizált } \\
\text { Herfindahl index }\end{array}$ & \multicolumn{2}{|c|}{0,001} & \multicolumn{2}{|c|}{0,001} \\
\hline
\end{tabular}

\section{Budapest nélkül}

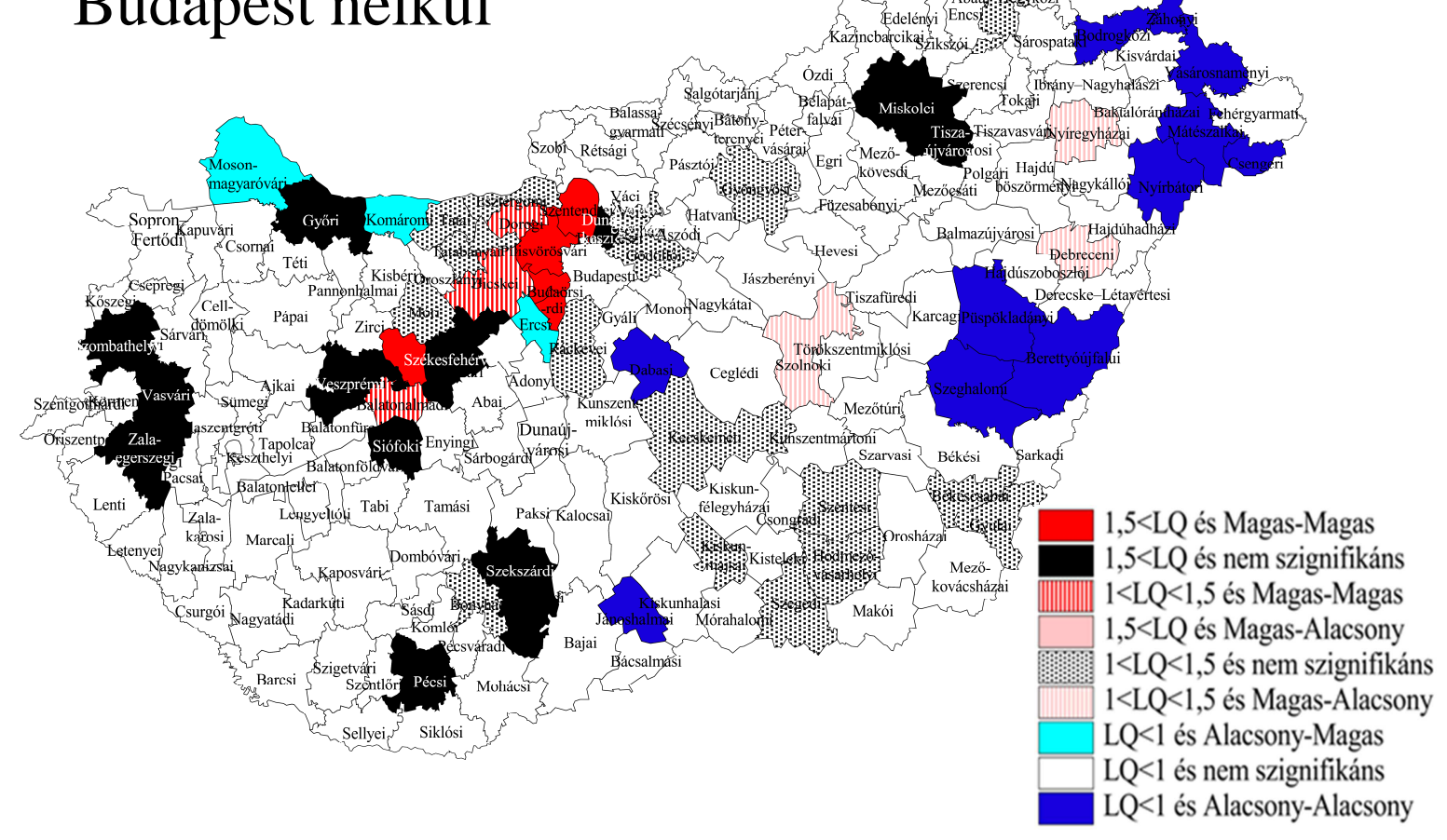


II. melléklet 22. tábla:

Budapesttel

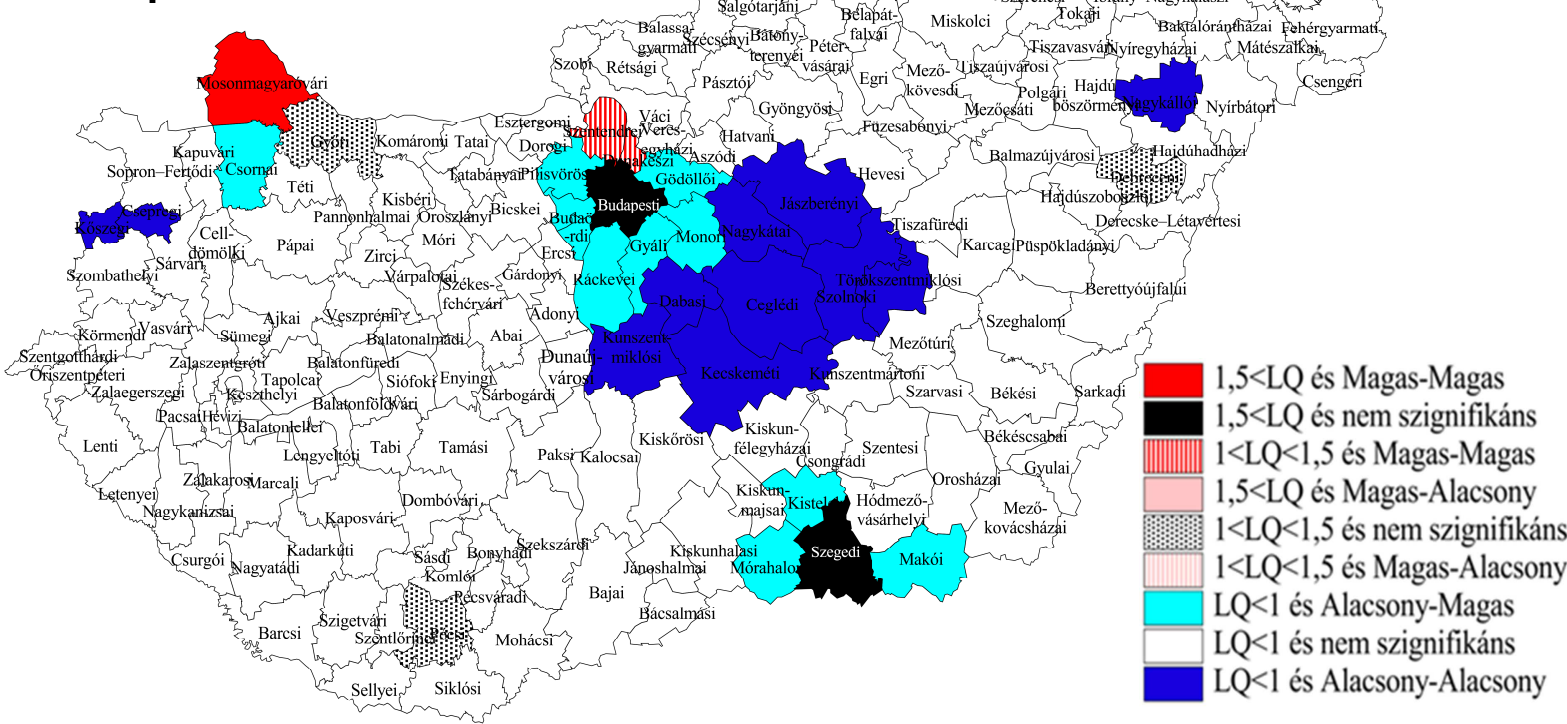

\begin{tabular}{|c|c|c|c|c|}
\hline \multirow{2}{*}{$\begin{array}{c}\text { 72 Tudományos } \\
\text { kutatás, fejlesztés }\end{array}$} & $\begin{array}{c}\text { Iparban, } \\
\text { építöiparban } \\
\text { foglalkoztatottakhoz }\end{array}$ & $\begin{array}{c}\text { Nemzetgazdaság } \\
\text { egészében } \\
\text { foglalkoztatottakhoz }\end{array}$ & $\begin{array}{c}\text { Iparban, } \\
\text { építöiparban } \\
\text { foglalkoztatottakhoz }\end{array}$ & $\begin{array}{c}\text { Nemzetgazdaság } \\
\text { egészében } \\
\text { foglalkoztatottakhoz }\end{array}$ \\
\hline Átlagos méret (fö) & \multicolumn{2}{|c|}{4} & \\
\hline Vállalkozások száma & \multicolumn{2}{|c|}{2956} & 0,023 & 0,011 \\
\hline Moran index & $-0,017$ & $-0,010$ & 0,214 & 0,288 \\
\hline p érték & 0,036 & 0,204 & 0,019 & 0,022 \\
\hline EG $\gamma$ mutató & 0,209 & 0,255 & & 0,010 \\
\hline $\begin{array}{c}\text { Normalizált } \\
\text { Herfindahl index }\end{array}$ & 0,022 & & \\
\hline
\end{tabular}

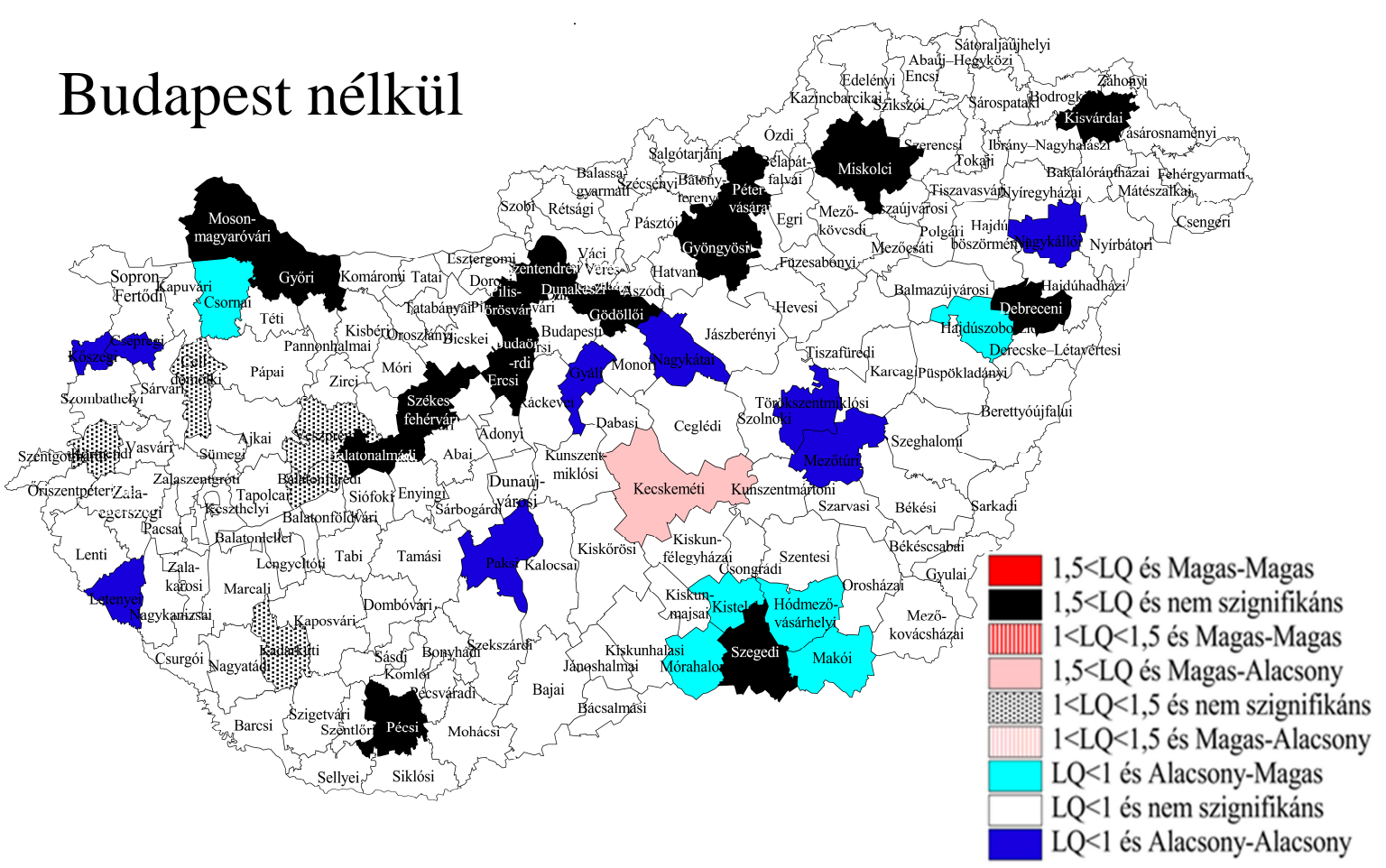


II. melléklet 23. tábla:

Budapesttel

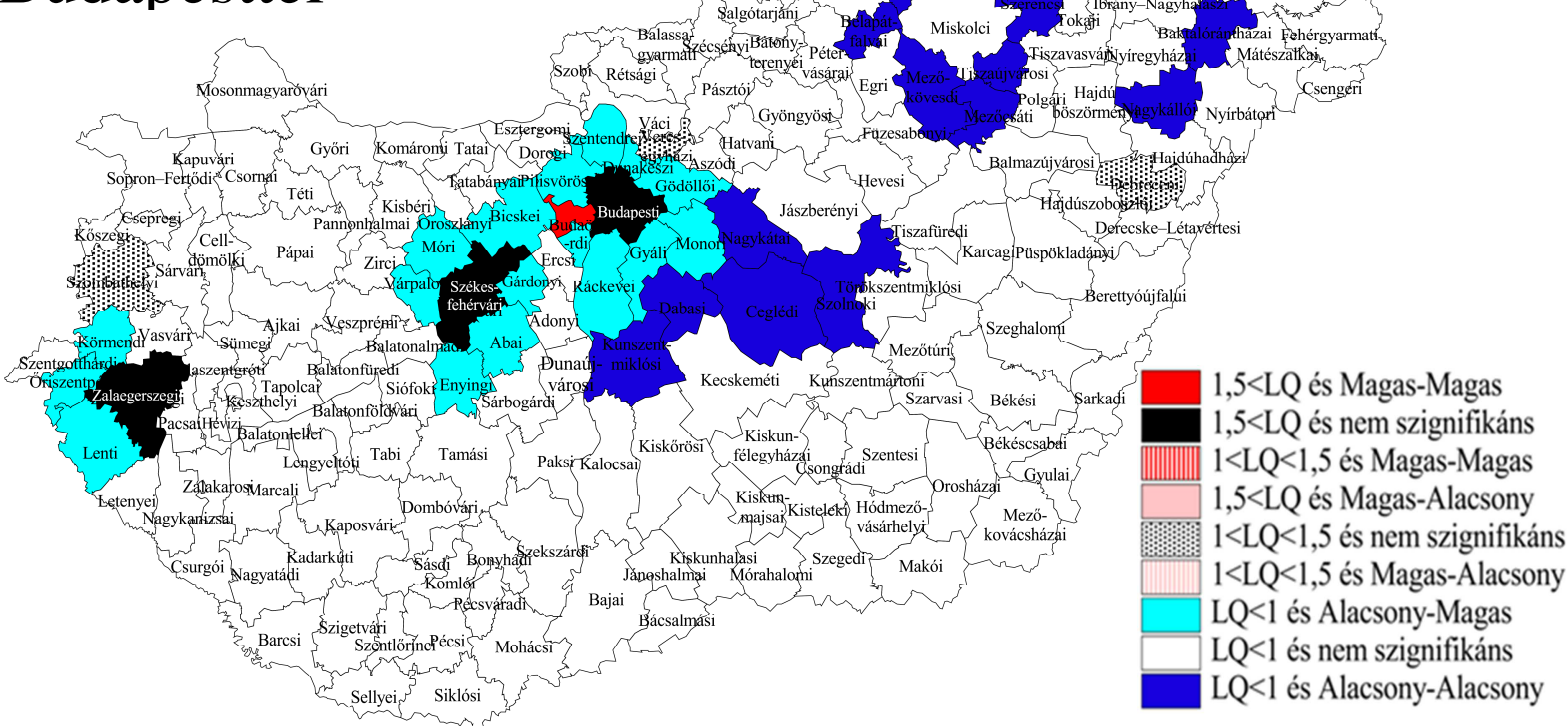

\begin{tabular}{|c|c|c|c|c|}
\hline \multirow{2}{*}{$\begin{array}{c}\text { 73 Reklám, } \\
\text { piackutatás }\end{array}$} & $\begin{array}{c}|c| \\
\text { Ipuarban, } \\
\text { építőiparban } \\
\text { foglalkoztatottakhoz }\end{array}$ & $\begin{array}{c}\text { Nemzetgazdaság } \\
\text { egészében } \\
\text { foglalkoztatottakhoz }\end{array}$ & $\begin{array}{c}\text { Iparban, } \\
\text { építöiparban } \\
\text { foglalkoztatottakhoz }\end{array}$ & $\begin{array}{c}\text { Nemzetgazdaság } \\
\text { egészében } \\
\text { foglalkoztatottakhoz }\end{array}$ \\
\hline Átlagos méret (fó) & \multicolumn{2}{|c|}{4} & & \multicolumn{2}{c|}{3} \\
\hline Vállalkozások száma & \multicolumn{2}{|c|}{6591} & $-0,004$ & $-0,017$ \\
\hline Moran index & $-0,012$ & $-0,006$ & 0,376 & 0,488 \\
\hline p érték & 0,119 & 0,448 & 0,005 & 0,006 \\
\hline EG $\gamma$ mutató & 0,189 & 0,230 & & 0,012 \\
\hline $\begin{array}{c}\text { Normalizált } \\
\text { Herfindahl index }\end{array}$ & \multicolumn{2}{|c|}{0,003} & & \\
\hline
\end{tabular}

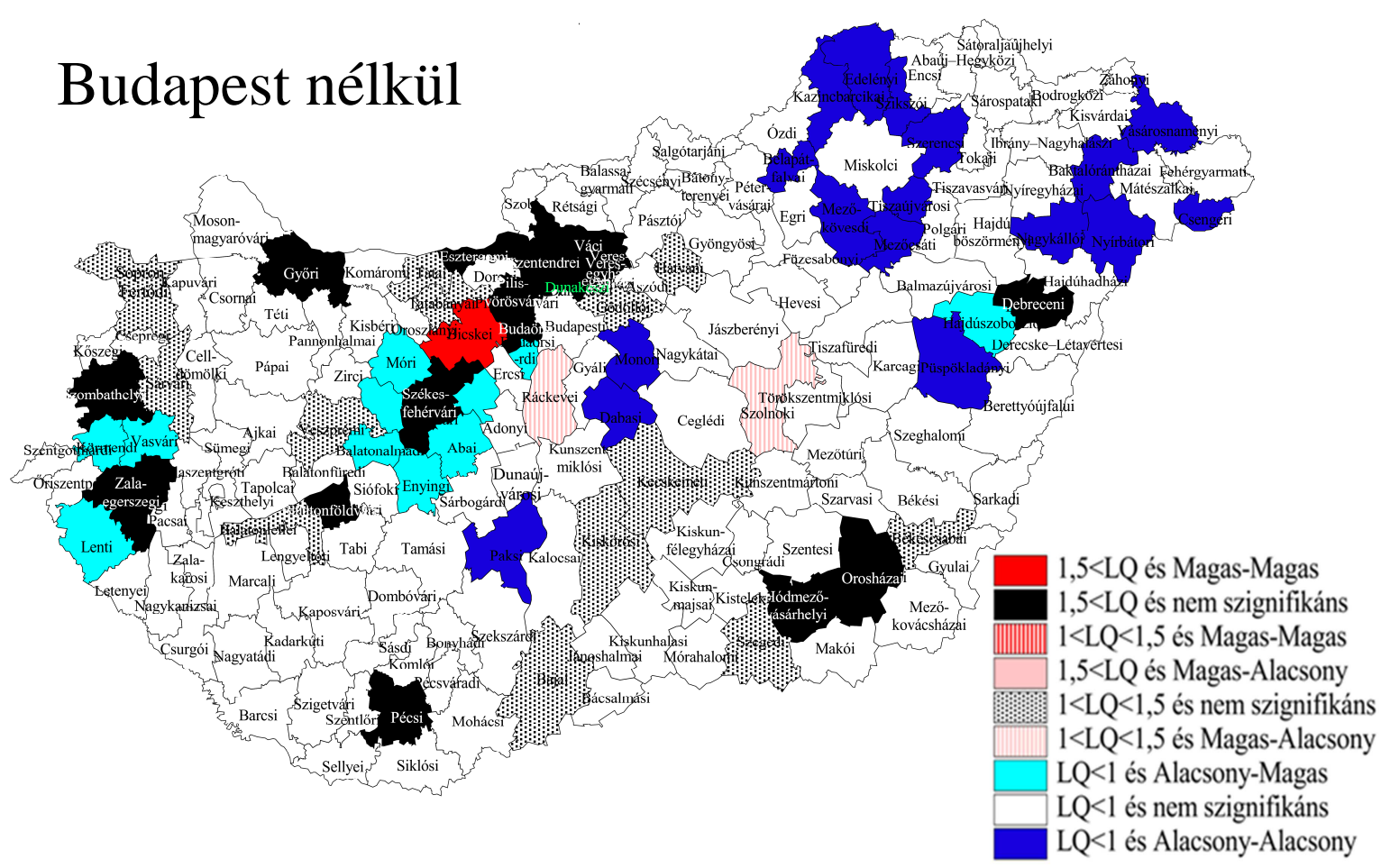


II. melléklet 24. tábla:

Budapesttel

\begin{tabular}{|c|c|c|c|c|}
\hline \multirow[b]{2}{*}{$\begin{array}{l}74 \text { Egyéb szakmai, } \\
\text { tudományos, } \\
\text { múszaki tevékenység }\end{array}$} & \multicolumn{2}{|c|}{ Budapesttel } & \multicolumn{2}{|c|}{ Budapest nélkül } \\
\hline & $\begin{array}{c}\text { Iparban, } \\
\text { építőiparban } \\
\text { foglalkoztatottakhoz }\end{array}$ & $\begin{array}{c}\text { Nemzetgazdaság } \\
\text { egészében } \\
\text { foglalkoztatottakhoz }\end{array}$ & $\begin{array}{c}\text { Iparban, } \\
\text { építőiparban } \\
\text { foglalkoztatottakhoz }\end{array}$ & $\begin{array}{c}\text { Nemzetgazdaság } \\
\text { egészében } \\
\text { foglalkoztatottakhoz }\end{array}$ \\
\hline Átlagos méret (fö) & \multicolumn{2}{|c|}{3} & \multicolumn{2}{|c|}{3} \\
\hline Vállalkozások száma & \multicolumn{2}{|c|}{7810} & \multicolumn{2}{|c|}{3911} \\
\hline Moran index & 0,036 & 0,039 & 0,162 & 0,150 \\
\hline p érték & 0,011 & 0,002 & 0,003 & 0,004 \\
\hline EG $\gamma$ mutató & 0,059 & 0,084 & 0,004 & 0,005 \\
\hline $\begin{array}{c}\text { Normalizált } \\
\text { Herfindahl index }\end{array}$ & \multicolumn{2}{|c|}{0,003} & \multicolumn{2}{|c|}{0,004} \\
\hline
\end{tabular}

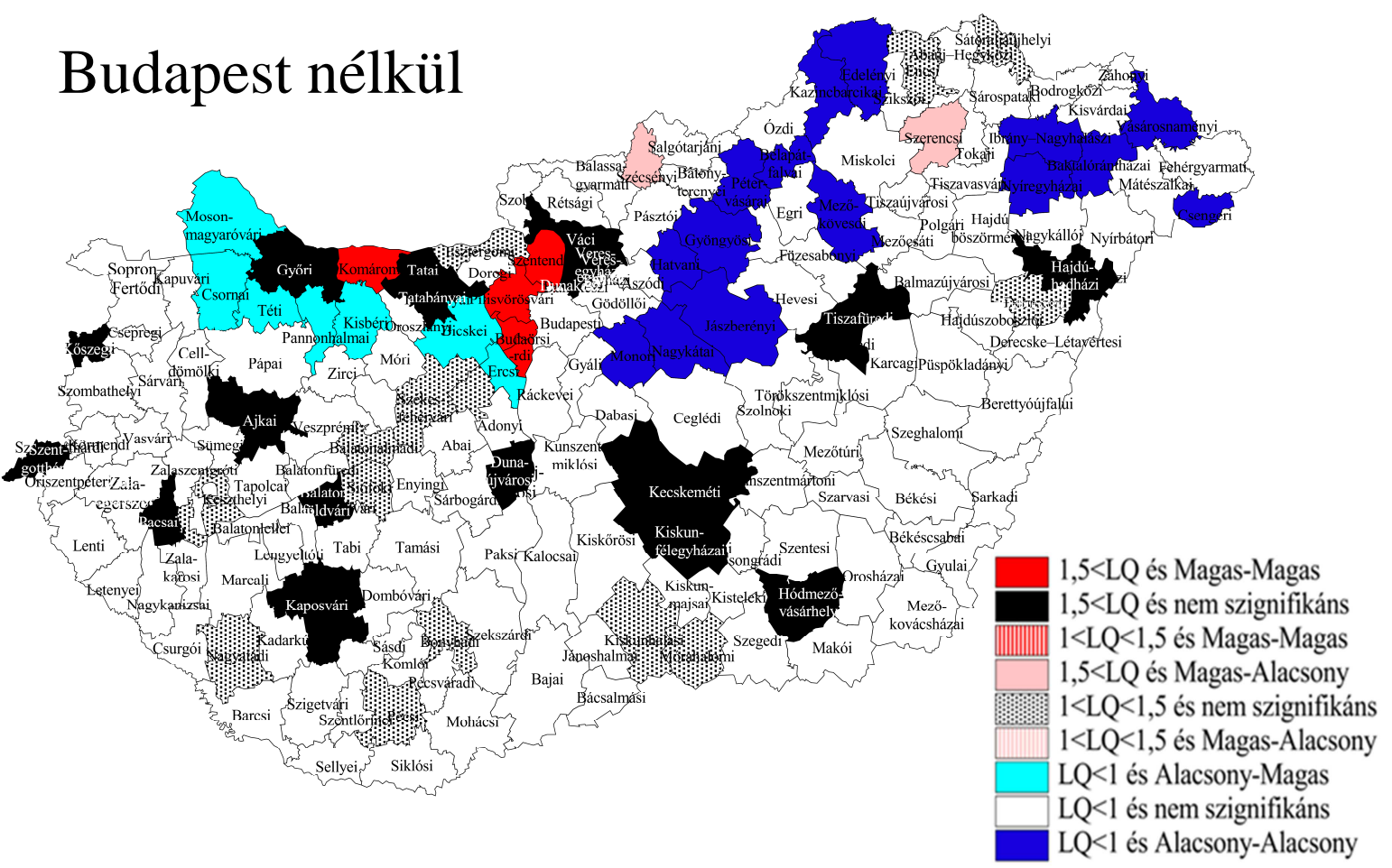


II. melléklet 25. tábla:

Budapesttel

\begin{tabular}{|c|c|c|c|c|}
\hline \multirow[b]{2}{*}{$\begin{array}{l}78 \text { Munkaerópiaci } \\
\text { szolgáltatás }\end{array}$} & \multicolumn{2}{|c|}{ Budapesttel } & \multicolumn{2}{|c|}{ Budapest nélkül } \\
\hline & $\begin{array}{c}\text { Iparban, } \\
\text { építöiparban } \\
\text { foglalkoztatottakhoz }\end{array}$ & $\begin{array}{c}\text { Nemzetgazdaság } \\
\text { egészében } \\
\text { foglalkoztatottakhoz }\end{array}$ & $\begin{array}{c}\text { Iparban, } \\
\text { építőiparban } \\
\text { foglalkoztatottakhoz }\end{array}$ & $\begin{array}{c}\text { Nemzetgazdaság } \\
\text { egészében } \\
\text { foglalkoztatottakhoz }\end{array}$ \\
\hline Átlagos méret (fö) & \multicolumn{2}{|c|}{66} & \multicolumn{2}{|c|}{45} \\
\hline Vállalkozások száma & \multicolumn{2}{|c|}{1625} & \multicolumn{2}{|c|}{834} \\
\hline Moran index & $-0,034$ & $-0,026$ & 0,015 & 0,001 \\
\hline p érték & 0,004 & 0,006 & 0,228 & 0,345 \\
\hline EG $\gamma$ mutató & 0,181 & 0,224 & 0,011 & 0,011 \\
\hline $\begin{array}{c}\text { Normalizált } \\
\text { Herfindahl index }\end{array}$ & \multicolumn{2}{|c|}{0,029} & \multicolumn{2}{|c|}{0,025} \\
\hline
\end{tabular}

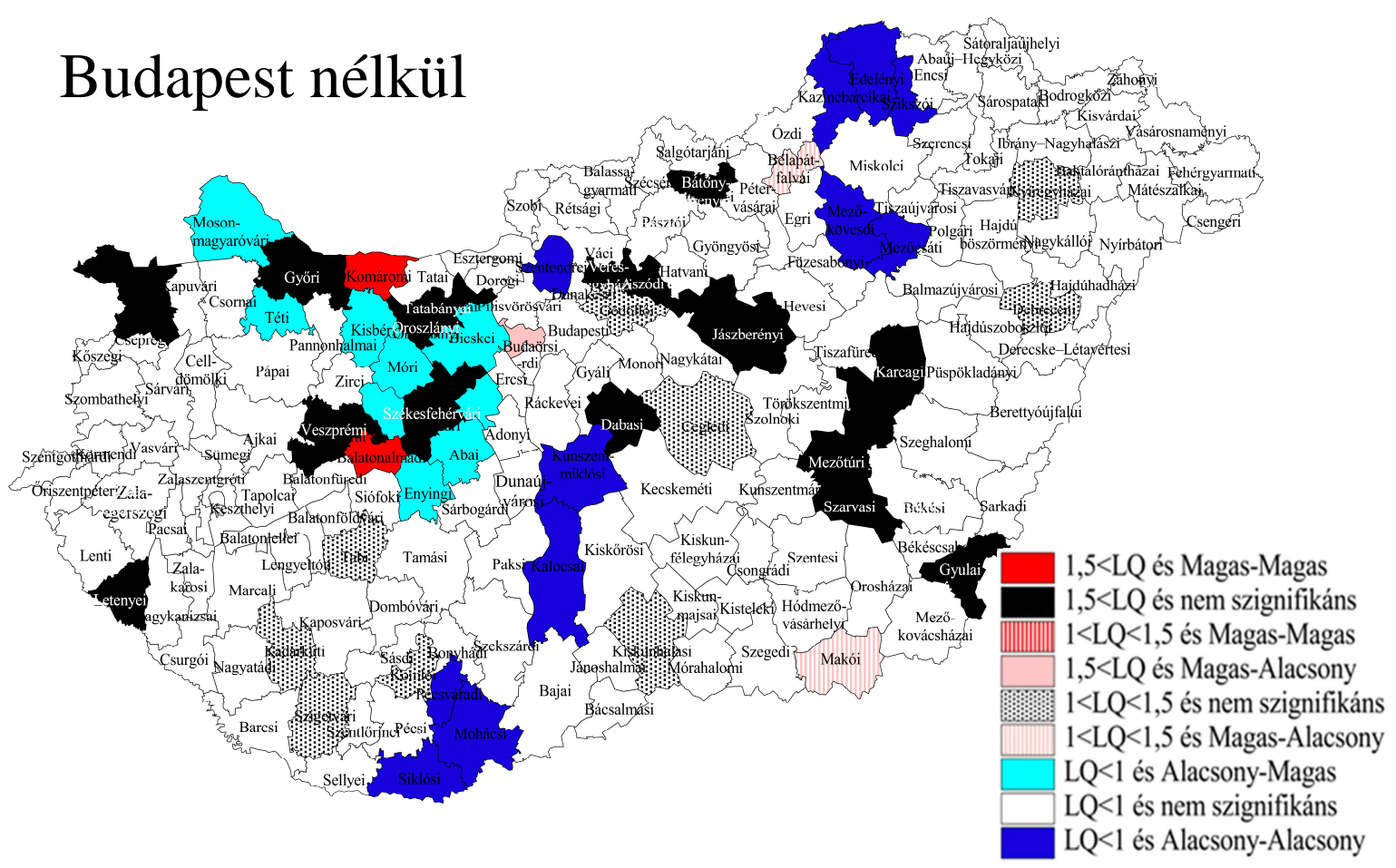




\section{II. melléklet 26. tábla:}

\section{Budapesttel}

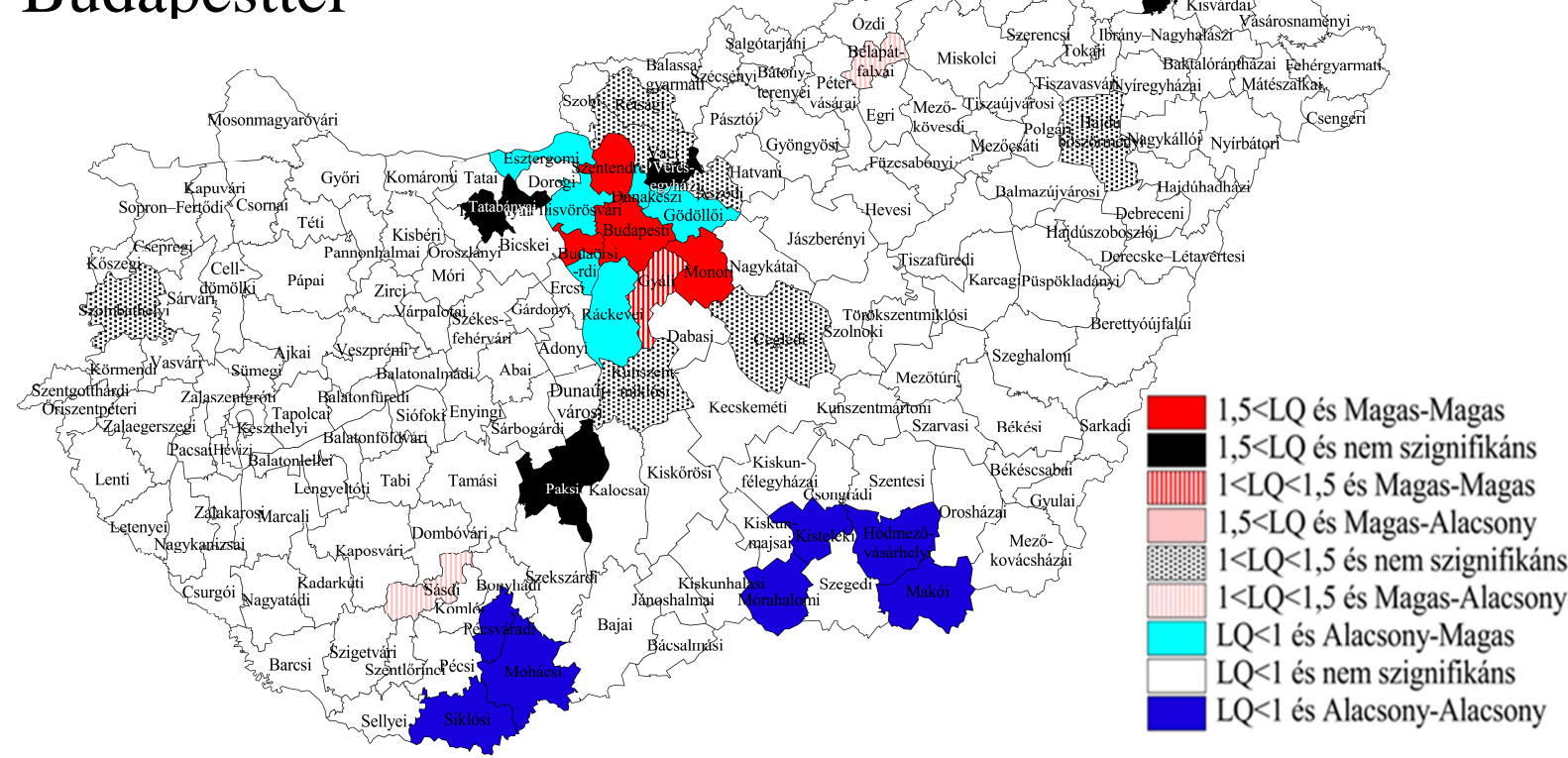

\begin{tabular}{|c|c|c|c|c|}
\hline \multirow[b]{2}{*}{$\begin{array}{l}80 \text { Biztonsági, } \\
\text { nyomozói } \\
\text { tevékenység }\end{array}$} & \multicolumn{2}{|c|}{ Budapesttel } & \multicolumn{2}{|c|}{ Budapest nélkül } \\
\hline & $\begin{array}{c}\text { Iparban, } \\
\text { építőiparban } \\
\text { foglalkoztatottakhoz }\end{array}$ & $\begin{array}{c}\text { Nemzetgazdaság } \\
\text { egészében } \\
\text { foglalkoztatottakhoz }\end{array}$ & $\begin{array}{c}\text { Iparban, } \\
\text { építőiparban } \\
\text { foglalkoztatottakhoz }\end{array}$ & $\begin{array}{c}\text { Nemzetgazdaság } \\
\text { egészében } \\
\text { foglalkoztatottakhoz }\end{array}$ \\
\hline Átlagos méret (fö) & \multicolumn{2}{|c|}{10} & \multicolumn{2}{|c|}{8} \\
\hline Vállalkozások száma & \multicolumn{2}{|c|}{5007} & \multicolumn{2}{|c|}{2829} \\
\hline Moran index & 0,048 & 0,050 & 0,095 & 0,107 \\
\hline p érték & 0,002 & 0,000 & 0,028 & 0,019 \\
\hline EG $\gamma$ mutató & 0,102 & 0,134 & 0,004 & 0,005 \\
\hline $\begin{array}{c}\text { Normalizált } \\
\text { Herfindahl index }\end{array}$ & \multicolumn{2}{|c|}{0,007} & \multicolumn{2}{|c|}{0,009} \\
\hline
\end{tabular}

\section{Budapest nélkül}

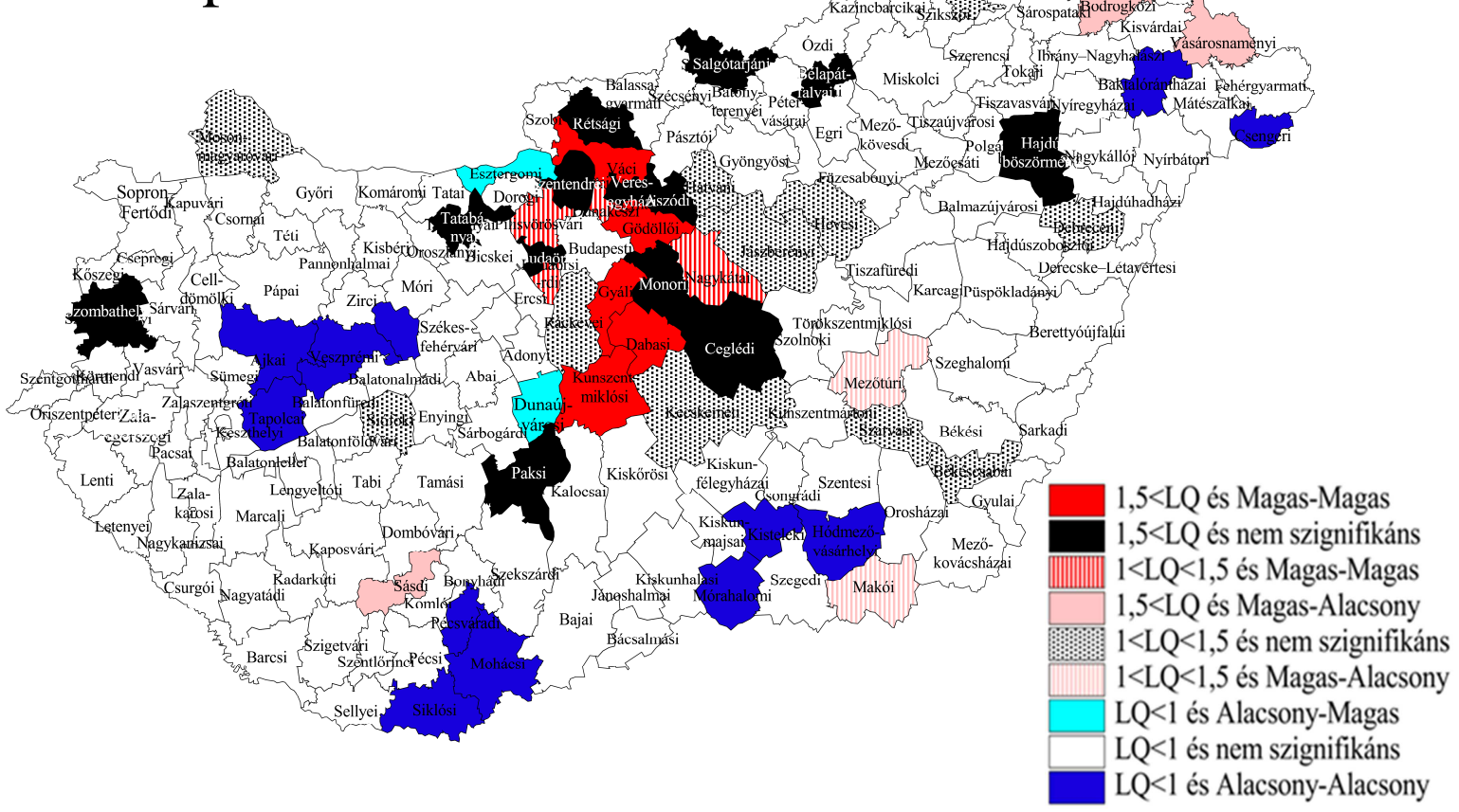

